

\section{BERKELEY}

LIBRARY

UNIVERSITY OF

CALIFORNIA

EARTH

SCIENCES

LIBRARY

LIBRARY

OF THE

UNIVERSITY OF CALIFORNIA.

Class

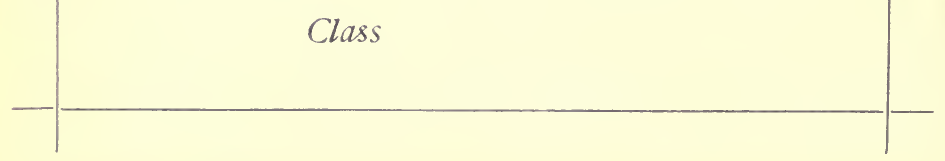



LANDSCAPE IN HISTORY

AND OTHER ESSAYS 
s. 


\title{
Landscape in History
}

\section{And other Essays}

\author{
By \\ Sir Archibald Geikie \\ D.C.L., F.R.S.
}

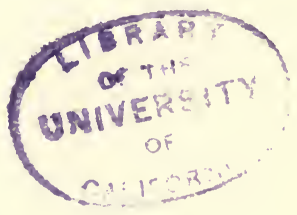

London

Macmillan and Co., Limited

New York: The Macmillan Company

1905 
$0_{0} C^{-3}, 5$

$\mathrm{Cs}^{2} \mathrm{a}^{2}$

EArfil

SEIIVICES

LIBRARY

GLASGOW : PRINTED AT THE UNIVERSITY PRESS BY ROBERT MACLEHOSE AND CO. LTD. 


\section{PREFACE}

THE present volume consists of a collection of Essays and Addresses which have appeared at intervals since the publication of my Geological Essays at Home and Abroad. Half of them deal with Scenery in its geological relations and in its influence on human progress-a subject which for many years has engrossed much of my thought. Others discuss the problem of the Age of the Earth, while two are biographical, and one deals with the place of Science. in modern education.

I have to thank the editors of the Fortnightly, Contemporary, and International Quarterly Reviews for their courtesy in readily according me permission to reprint the essays which have appeared in these publications.

I $5_{\text {th }}$ January, 1905. 



\section{CONTENTS}

I

PAGE

LANDSCAPE IN HISTORY, -

II

Landscape and the Imagination, - $\quad$ - $\quad-\quad 28$

IIÌ

LANDSCAPE AND LiteratURE, - - - - $\quad$ - 76

\section{IV}

The Origin of the Scenery of the British

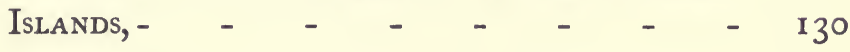

V

The Centenary of Hutton's 'Theory of the EARTH,' - $\quad$ - $\quad$ - $\quad$ - $\quad$ - $\quad$ - $\quad$ - $\quad$ - 158

VI

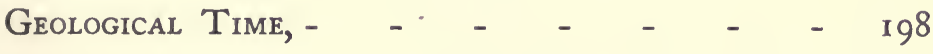

VII

The Life and Letters of Charles Darwin, - 234 
viii

\section{CONTENTS}

PAGE

VIII

Hugh Miller: His Work and Influence, - - 257

IX

Science in Education, - $\quad$ - $\quad$ - $\quad$ - $\quad$ - $\quad$ - 282

X

The Roman Campagna, - $\quad$ - $\quad$ - $\quad 308$ 


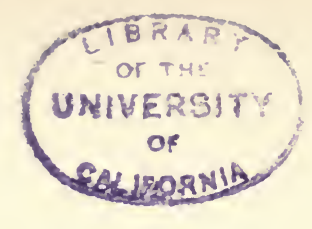

\section{I}

\section{Landscape in History ${ }^{1}$}

Among the obscure problems in the history of mankind a foremost place must be given to the question of the origin and distribution of the various races of men. Undoubtedly two main factors in the differentiation of these racès have been climate and geography. These same physical conditions still perpetuate, if they did not actually originate, the racial distinctions. Even where we may hesitate to adopt a theory as to the initial start of any one of the great branches of mankind, we can hardly fail to recognise that the several nations or tribes comprised within one of these branches are marked off from each other by more or less definite peculiarities, of which some at least may probably be referred to the influence of environment. The landscapes of a country, the form, height, and trend of its mountain-ranges, the position and extent of its plains and valleys, the size and direction of its rivers, the varying nature of its soils and climate, the presence or absence of useful minerals,

${ }^{1}$ The substance of this Essay formed an address to the Oxford University Scientific Club, in 1887. 
nearness to or distance from the sea, the shape of the coast-line whether rocky or precipitous, or indented with creeks and harbours - all these and other aspects of the scenery of the land have contributed their share to the moulding of national history and character. For illustrations of this external influence we need go no further than the British Isles, and contrast the aspect and history of central England with those of the Scottish Highlands. ${ }^{1}$

Some of these dominant elements in our surroundings remain permanently with little or no appreciable change. The mountains and the plains are now essentially what they were in the infancy of man, though their mantle of vegetation may have been greatly altered. In other cases, geological processes are continually at work, effecting changes which, though individually of small account, become important in the course of centuries by constant repetition. Thus on some parts of our coast-line there has been a great destruction of land, in others the land has gained on the sea. But man himself has become a geological agent, and has in that capacity greatly modified the surface of many of the countries which he has inhabited. The progress of agriculture has led to the draining of mosses, the felling of forests and the transformation of heaths and wastes into arable land. The increase of sheep and cattle has been the means of clothing the hills with pasture, in place of their former rough herbage and copsewood. And man himself becomes involved in the consequences of the changes which he sets in motion. This subject

1 This illustration of the subject is discussed in my Geological Essays at Home and Abroad, p. 253. 
may obviously be discussed independently either from the scientific or from the historical side. Any investigation which deals with the changes that have taken place in the outward aspect of a country since man first set foot upon its surface, and with the sources of information regarding them, must obviously appeal strongly to the lover of science, inasmuch as it brings before him the evidence for various kinds of geological process, the actual operation and rate of progress of which he may thereby be enabled to watch and determine. It may thus be made to throw light upon one of the vexed problems of science-the value of time in geological inquiry. But it is of the relations of such an investigation to human history that I would first more particularly speak. Such inquiries seem to me eminently calculated to engage the sympathies and even the active co-operation of literary students. There can be no doubt that the advancement of our knowledge of the mutations of the land since the beginning of history must depend largely upon help from the study of historical documents.

No long series of years has passed since the truth was recognised that man is in large measure the creature of his environment; that his material progress and mental development have been guided and modified by the natural conditions in which he has been placed. The full extent and application of this truth, however, are perhaps not even yet comprehended. If the surrounding and limiting conditions have been such potent factors in human development, we may well believe that any serious change or modification in them cannot but have reacted upon man. If nature alters her 
aspect to him, either spontaneously on her own part or as the result of human interference with her ways, he too will in some measure be affected thereby, and his relations to her will be influenced. What then have been the kind and amount of the mutations in the face of nature since man first appeared? Although the answer to this question will here be sought in the evidence furnished by Great Britain alone, it will be understood that the principles laid down for the conduct of the inquiry with regard to this country must be of general application to other regions of the globe.

Let me remark at the outset that considerable progress has been made in the investigation of this question, both from its scientific and its historical side. Lyell, and Prestwich, with the geologists who have followed them, laid a solid foundation of knowledge regarding the later mutations in the physical geography of Britain. Guest, Pearson, Freeman, Green, and others, have shown in how many ways the historical development of the people has been influenced by the topographical features of the country. Yet in spite of all that has been done, I do not hesitate to say that we are still only a little way beyond the threshold of this wide subject. No one has realised more vividly at once the importance of the inquiry and the imperfection of the available data than the late $\mathrm{Mr}$. J. R. Green. He would fain have been able to reconstruct the successive phases through which our landscapes have passed since the dawn of history; and he did more in this respect with his materials than perhaps any other living man could have done. But 


\section{SOURCES OF INFORMATION}

the detailed evidence was wanting to him; and it has still in large measure to be gathered before the ideal of the historian can be reached. Now, I am desirous of insisting upon the fact that this detailed evidence does not lie shut up from the reach of all but the practised man of science and the mature historian. Much of it, whether in the literary or scientific domain, may be gleaned by any young undergraduate who will bring to the task quickness of observation and accuracy of judgment. As the harvest is abundant but the labourers few, I would fain enlist the sympathy and co-operation of any who may be able and willing to help.

There are four obvious sources of information regarding former conditions of the land. First comes the testimony of historical documents, then that of placenames, next that of tradition, and lastly, that of geological evidence.

(I) One might suppose that for what has taken place during the historical period, the documentary records would be all sufficient. But as it is only recently that the subject has been determined to be worthy of the historian's serious attention, we cannot look for much light to be thrown upon it in the pages of the ordinary histories. Still less need we expect to meet with any full measure of information regarding it in the original documents from which such histories have been mostly compiled. In truth, the facts of which we are in search must be gleaned from brief allusions and implications rather than from actual descriptions. It was no part of the duty of an old chronicler purposely to record any natural fact, short of some terrific earthquake or storm 
that destroyed human life and damaged human property. But in describing historical events he could hardly avoid reference to woods, lakes, marshes, and other natural features which served as boundaries to the theatre of these events. By comparing, therefore, his local topography with the present aspect of the same localities, we may glean some interesting particulars as to changes of landscape in the course of centuries. Such a comparison, however, to be effective and trustworthy, involves two special qualifications. The inquirer must be master of the language and style of the author he is studying, and he must be completely familiar with the present condition of the ground to which allusion is made. The want of this combination of knowledge has led to some curious blunders on the part of able scholars.

It is evident, then, that an ample domain of research is here opened out to the student. In a general sense, every kind of historical document may be available for the purposes of the inquiry. England fortunately possesses in Domesday Book the results of a minute examination of the greater part of the country in the latter half of the eleventh century. For other portions of our islands much information may be gleaned in quarters that might be thought the most unlikely. Besides the narratives of the old Chronicles, which might be expected to contain at least occasional incidental reference to physical features, Charters and other legal documents, in dealing with the holding and transference of land, not infrequently throw light on the former aspect of the ground with which they are connected. The Cartularies of some of our ancient 


\section{HISTORICAL DOCUMENTS}

abbeys, besides affording glimpses into the inner life of these establishments, which do not seem to have been always abodes of peace and studious retirement, give indications of the former areas of forest, woods and mosses, or the positions of lakes now reduced in size or effaced. Old Acts of Parliament, looked at from our present point of view, are by no means always repulsive reading. They have one great advantage over their modern representatives in that they are often commendably brief; and in their occasional quaint local colouring, they afford material for interesting comparison with existing topography.

Among historical documents I include poems of all kinds and ages. Our earliest English literature is poetical; and from the days of Caedmon down to our own time, the typical characters of landscape have found reflection in our national poetry. It is not merely from what are called descriptive poems that information of the kind required is to be gathered. The wild border-ballad, full of the rough warfare of the time, has a background of bare moorland, treacherous moss-hags, and desolate hills, which can be compared with the aspect of the same region to-day. The gentler lyrics of a later time take their local colouring from the glades and dells, the burns and pastures where their scenes are laid. In the stately cadence of the Faery Queen, among the visionary splendours of another world, the rivers of England and Ireland are pictured, each with its characters touched off as they appeared in the days of Elizabeth. And in Drayton's quaint, but somewhat tiresome Polyolbion, abundant material is supplied for a comparison between the topography 
of England at the beginning of the seventeenth century and that of our own time. ${ }^{1}$

But these comparisons have still to be worked out. As an example of the kind of use that may be made of them, and of the light which our poetry may cast, not only upon physical changes, but upon historical facts, I would refer to the passages in Barbour's poem of The Bruce descriptive of the Battle of Bannockburn. ${ }^{2}$ I do not contend for the complete historical veracity of the Archdeacon of Aberdeen, though I think he hardly deserves the sweeping and contemptuous condemnation meted out to him by J. R. Green. As he was born only some two years after the battle, as he had travelled a good deal, and as the field of Bannockburn lay across the land-route from the north to the south of Scotland, we may believe him to have made himself personally acquainted with the ground. At least, he could easily obtain information from many who had been themselves actors in the fight. He had no object to gain by drawing on his imagination for the local topography, more especially as his little bits of local description were not in any way required for the glorification of his hero. I think, therefore, that when Barbour describes a piece of ground, we may take his description as a fairly accurate representation of the topography, at least in his own day; and the scene could hardly have changed much in the generation that had passed since the time of Bruce. Now, many

1 This part of the subject is more fully treated in the two following essays.

${ }^{2} \mathrm{~A}$ portion of this passage has been inserted in my Scenery of Scotland. 
persons who have visited the site of the Battle of Bannockburn have felt some difficulty in understanding why the English army did not easily outflank the left wing of the Scots. At present, a wide fertile plain stretches for miles north and south on the east side of the low plateau on which Bruce's forces were drawn up. ${ }^{1}$ A small body of the English cavalry did, indeed, make its way across this plain until overtaken and cut to pieces by Randolph. But why was this force so easily dispersed, and why was no more formidable and persistent effort made to turn that left flank? It is very clear that, had the topography been then what it is now, the Battle of Bannockburn must have had a far other ending.

The true explanation of the difficulty seems to me to be supplied by some almost casual references in Barbour's account of the operations. He makes Bruce, in addressing his followers, allude to the advantage they would gain should the enemy attempt to pass by the morass beneath them. The poet further narrates how the Carse, that is, the low flat land on the left, was dotted with pools of water: how the English, in order to effect a passage, broke down houses, and tried to bridge over these pools with doors, windows, and thatch from the cottage roofs; and how, with the assistance of their compatriots in Stirling Castle, they were so far successful that Clifford's troop of horse, and, possibly, some more of the English army, got safely over to the hard ground beyond. We thus learn that Bruce's famous device of the 'pots' was only

${ }^{1}$ This plain is one of the upraised marine platforms referred to in a later part of this Essay. 
an extension of the kind of defence that nature had already provided for him. The ground on his left, now so dry and so richly cultivated, was then covered with impassable bogs and sheets of water; and the huge army of Edward was consequently compelled to crowd its attack into the narrow space between these bogs and the higher grounds on Bruce's right.

(2) Another wide field of inquiry for information touching changes in the aspect of the country is supplied by the etymology of place-names. These names, at least those of them that date from old times, possess a peculiar value and interest as abiding records of the people who gave them, and also, in many cases, of the circumstances in which they were given. We are at present concerned only with those that embody some physical fact in the topography. Many of these are as appropriate now as they were at first; for the features to which they were applied have remained unaltered. Ben Dearg shows the same red slopes that struck the earliest Celtic tribes who looked up to it from the bays and glens of Skye. The big stones on the summit of Penmaenmawr still stand as memorials of the British people who erected them and gave their name to the hill.

But in innumerable instances the appositeness of the designation has been lost. The name has, in fact, been more permanent than the feature to which it is applied. The one has survived in daily speech from generation to generation: the other has wholly passed away. By comparing the descriptive epithet in the name with the present aspect of the locality, some indication, or even, perhaps, some measure of the nature and amount 
of the changes in the topography, may still be recovered.

Now in researches of this kind the liability to blunder is so great, and many able writers have blundered so egregiously, that the inquiry ought not to be entered upon without due preparation, and should not be continued without constant exercise of the most scrupulous caution. The great danger of being betrayed into error by the plausibilities of phonetic etymology should never for a moment be lost sight of. Where possible, the earliest form of the name should be recovered, for in the course of time local names are apt to be so corrupted as to lose all obvious trace of their original orthography.

The Celtic place-names ${ }^{1}$ are as a whole singularly descriptive. The Celtic tribes, indeed, have manifested, in that respect, a keener appreciation of landscape and a more poetical eye for nature than their Saxon successors. Who that has ever stood beneath the sombre shadow of the cloud that so often rests on the shoulder of the Grampians will fail to recognise the peculiar fitness of the Gaelic name for the highest summit of the chain-Ben-na-muig-dubh, 'the mountain of dark gloom'? Or who has ever watched the Atlantic billows bursting into white foam against the cliffs of Ardnamurchan and did not acknowledge that only a poetic race could have named the place ' the headland of the great ocean.' The colours of mountain and river have been seized upon by these people as descriptive characters that have suggested local names.

${ }^{1}$ Dr. Joyce's excellent Irish Names of Places is the best authority on this subject. 
Swiftness and sluggishness of flow have furnished discriminating epithets for streams. Moors, forests, woodlands, copses, groups of trees, solitary bushes, lakes, mosses, cliffs, gullies, even single boulders, have received names which record features in the landscape that struck the imagination of the old Celt, and which are still in use, even when the features that suggested them have long vanished out of sight. From this source glimpses may be had of the character of the vegetation and of the wild animals in prehistoric times. Thus we learn that the desolate, treeless tract of Rossshire known as the Dirriemore (great wood) must once have been clothed with forest. How numerous wild boars were in the country is shown by the frequent occurrence of the name of the animal (Torc, turk) in local topography. The former haunts of the wolf are indicated by its Gaelic appellation (madah, maddie) in Highland place-names. Many descriptive names which have never found a place on any map are well known to the Welsh and Gaelic-speaking inhabitants, who in the more mountainous and trackless regions have often a wonderful acquaintance with the details of the topography.

Here, then, in our Celtic place-names lies a wide and as yet, for large districts, but little worked field for exploration. Civilisation has advanced less rapidly and ruthlessly in the Celtic-speaking parts of the country, where, too, there are fewer historical records of progress and change. But the topographical names when carefully worked out supply a good deal of information regarding former conditions of surface whereof every other memorial has perished. 
Our Saxon progenitors, also, gave appropriate local names; but with a sturdy self-assertion, and prosaic regard for plain fact, they chose to couple their own cognomina with them. If a settler fenced in his own inclosure he called it his 'ton' or his 'ham.' If he felled the trees of the primeval woodlands and made his own clearance, it became his 'fold.' If he built himself a mud cottage, it was his 'cote,' or if he attained to the dignity of a farm, he called it his 'stead.' As he and his brethren increased their holdings and drew their houses together for companionship and protection, the village kept their family name. But besides these patronymic epithets, which are of such value in tracing out the early settlement of the country, the English gave more or less descriptive local names. In their ' holts' and 'hursts,' 'wealds ' and 'shaws,' we can still tell where their woods lay. In their 'leighs,' 'fields,' and 'royds,' we can yet trace the open clearings in these woods. But for the broad landmarks, rivers, and larger natural features of the country, the Saxons were generally content to adopt, in some more or less corrupted form, the names already given by the Celtic tribes who had preceded them.

(3) As another but less reliable source of information regarding alterations in the surface of the country, I would make brief allusion to the subject of local tradition. In these days of education and locomotion, we can hardly perhaps realise how tenacious, and on the whole faithful, the human memory may be in spite of the absence of written or printed documents. Even yet we see the unbroken and exact record of the true boundaries of a parish or township handed down in the 
annual beating of the bounds or riding of the marches. And even where no such ceremony has tended to perpetuate the remembrance of topographical details, tradition, though it may vary as to historical facts, is often singularly true to locality. I am tempted to give what seems to me a good example of this fidelity of tradition. Many years ago among the uplands of Lammermuir I made the acquaintance of an old maiden lady, Miss Darling of Priestlaw, who with her bachelor brothers tenanted a farm which their family had held for many generations. In the course of her observant and reflective life she had gathered up and treasured in her recollection the traditions and legends of these pastoral solitudes. I well remember, among the tales she delighted to pour into the ear of a sympathetic listener, one that went back to the time of the Battle of Dunbar. We know from his own letters in what straits Cromwell felt himself to be when he found his only practicable line of retreat through the hills barred by the Covenanting army, and how he wrote urgently to the English commander at Newcastle for help in the enemy's rear. It has usually been supposed that his communications with England were kept up only by sea. But the weather was boisterous at the time, and a vessel bound for Berwick or Newcastle might have been driven away from land. There is therefore every probability that Cromwell would try to send a communication by land also. Now the tradition of Lammermuir maintains that he did so. The story is told that he sent two soldiers disguised as natives of the district to push their way through the hills and over the border. The men had got as far as 
the valley of the Whiteadder, and were riding past the mouth of one of the narrow glens, when a gust of wind, sweeping out of the hollow, lifted up their hodden-grey cloaks and showed their military garb beneath. They had been watched, and were now overtaken and shot. Miss Darling told me that tradition had always pointed to some old whin-bushes at the opening of the cleugh as the spot where they were buried. At her instigation the ground was dug up there, and among some mouldering bones were found a few decayed buttons with a coin of the time of Charles the First.

Tradition is no doubt often entirely erroneous; but it ought not, I think, to be summarily dismissed without at least critical examination. There are doubtless instances where it might come in to corroborate conclusions deducible from other and usually more reliable kinds of evidence.

(4) But of all the sources of information regarding bygone mutations of the surface of the land, undoubtedly the most important is that supplied by the testimony of geology. Early human chronicles are not only imperfect, but may be erroneous. The chronicle, however, which Nature has compiled of her past vicissitudes, though it may be fragmentary, is, at least, accurate. In interpreting it the geologist is liable, indeed, to make mistakes; but these can be corrected by subsequent investigation, while the natural chronicle itself remains unaffected by them. Moreover, it embraces a vast period of time. Historical evidence in this country is comprised within the limits of nineteen centuries. The testimony from Celtic topographical names 
may possibly go back some hundreds of years further. But the geological record of the human period carries us enormously beyond these dates. Hence, in so vast a lapse of time, scope has been afforded for a whole series of important geological revolutions. On every side of us we may see manifest proofs of these changes. The general aspect of the country has been altered, not once only, but many times. The agencies that brought about these changes have, in not a few instances, preserved tolerably complete memorials of them. We are thus enabled to trace the history of lakes and rivers, of forests and mosses: we can follow the succession of animals that have wandered over the land, and many of which had died out ere the days of history began: we can dimly perceive the conditions of life amidst the earliest human population of the country: we can recover abundant evidence of the extraordinary vicissitudes of climate which, since these ancient times, have affected not this land only, but the whole northern hemisphere.

The evidence from which these reconstructions of the former aspect of the country and its inhabitants can be deduced lies easily accessible around us. From the numerous caves in the limestone districts, abundant remains have been disinterred of the landanimals that were contemporary with aboriginal man, and among them relics of human workmanship have likewise been obtained. Our bogs have yielded skeletons of the Irish elk and other denizens of the primeval glades and woodlands, together with the canoes and stone-implements of the hunters of these animals. Our river-terraces reveal a long history of 


\section{EARLY ASPECT OF BRITAIN}

climatal changes onward from the later phases of the Ice-Age, during which the country witnessed successive migrations of northern and southern mammals accompanied by Palaeolithic and Neolithic men. The raised beaches and sunk forests contain relics of contemporary human workmanship which prove that man had already become an inhabitant of Britain before the land had settled into its present level above the sea.

It may be of advantage to consider here, from the various sources of information above enumerated, what appears to have been the condition of the surface of Britain at the dawn of authentic history and what have been the nature and origin of the changes which this surface has undergone within historic time. When the light of human testimony first begins to fall upon Britain at the advent of the Romans, the general aspect of the country must have presented in many respects a contrast to that which is now to be seen; and notably in the wide spread of its forests, in the abundance of its bogs and fens, and (through the northern districts) in the vast number of its lakes.

At the first coming of the Romans by far the larger part of the country was probably covered with wood. During the centuries of Roman occupation some of the less dense parts of the woodland were cleared. In driving their magnificent straight highways through the country, the Roman legionaries felled the trees for seventy yards on each side of a road, in order to secure themselves from the arrows of a lurking foe. So stupendous was the labour thus involved, that they gladly avoided forests where that was 
possible, and sometimes even swung their roads to right or left to keep clear of these formidable obstacles. For many hundreds of years after the departure of the legions, vast tracts of primeval forest continued to be impassable barriers between different tribes. In these natural fastnesses the wolf, brown bear, and wild boar still found a secure retreat. Even as late as the twelfth century the woods to the north of London swarmed with wild boars and wild oxen. Everywhere, too, the broken men of the community betook themselves to these impenetrable retreats, where they lived by the chase, and whence they issued for plunder and bloodshed. The forests were thus from time immemorial a singularly important element in the topography. They. have now almost entirely disappeared, and their former sites have as yet only been partially determined, though much may doubtless still be done in making our knowledge of them more complete.

In connection with this subject it should be remembered that, in many instances, the areas of wood and open land have in the course of generations completely changed places. The wide belts of clay-soil that sweep across the island, being specially adapted for the growth of trees, were originally densely timbered. But the process of clearance led to the recognition of the fact that these clay-soils were also eminently fitted for the purposes of agriculture. Hence, by degrees, the sites of the ancient forests were turned into corn-fields and meadows. On the other hand, the open tracts of lighter soil, where the earlier settlers established themselves, were gradu- 


\section{BOGS AND FENS}

ally abandoned, and lapsed into wastes of scrub and copsewood.

The fens and bogs of Britain played likewise a large part in the attack and defence of the country in Roman and later times. They were of two kinds. One series lay on the coast, especially of sheltered inlets, and were liable to inundation by high tides. The most notable of these was the wide tract of low, swampy land at the head of the Wash, our Fenland-an area where, secure in their amphibious retreats, descendants of the Celtic population preserved their independence not only through Roman but through Saxon times, if indeed, as Mr. Freeman conjectures, outlying settlements of them may not have lingered on till the coming of the Normans. The other sort of fens were those formed in the interior of the country by the gradual encroachment of marshy vegetation over tracts previously occupied by shallow sheets of fresh water, and over flat land. It was in these swamps that the Caledonians, according to the exaggerated statement of Xiphiline, concealed themselves for many days at a time, with only their heads projecting above the mire. At a far later period the peat-bogs of the debateable land between England and Scotland formed an important line of advance and retreat to the freebooters of the border, who could pick their way through sloughs that to less practised eyes and feet were impassable.

One of the distinguishing features among the topographical changes of the last few hundred years has been the disappearance of a vast number of these fens and bogs. In some cases they have been gradually silted up by natural processes; but a good many of 
them have no doubt been artificially drained. Their sites are still preserved in such Saxon names as Bogside, Bogend, Mossflats; and where other human record is gone, the black peaty soil remains to mark where they once lay. It would not be impossible with the help of such pieces of evidence and a study of the present contours of the ground to map out in many districts, now well drained and cultivated, the swamps that hemmed in the progress of our ancestors.

No one looking at the present maps of the north of England and Scotland would be led to suspect what a large number of lakes must have been scattered over the surface of these northern regions when the Romans set foot in the country. Yet if he turns to old maps, such as those of Timothy Pont, published some three hundred years ago, he will notice many sheets of water represented there which are now much reduced in size or entirely replaced by cultivated fields. If, farther, he scans the topographical names of the different counties, he will be able to detect the sites of other and sometimes still older lakes; while, if he sets to work upon the geological evidence by actual examination of the ground itself, he will be astonished to find how abundant at comparatively recent times were the tarns and lakes of which little or no human record may have survived, and often how much larger were once the areas of lakes that still exist. Owing to some peculiar geological operations that characterised the passage of the Ice-Age in the northern hemisphere, the land from which the snow-fields and glaciers retreated was left abundantly dotted over with lakes. The diminution and disappearance of these sheets of 
water are mainly traceable to the inevitable process of obliteration which sooner or later befalls all lakes great and small. Detritus is swept into them by rain and wind from the surrounding slopes and shores. Every brook that enters them is engaged in filling them up. The marsh-loving vegetation which grows along their shallow margins likewise aids in diminishing them. Man, too, lends his help in the same task. In early times he built his pile-dwellings in the lakes, and for many generations continued to cast his refuse into their waters. In later days he has taken the more rapid and effectual methods of drainage, and has turned the desiccated bottoms into arable land.

In connection with the geological changes that have affected the general surface of the country since the beginning of history, reference may here be made to those which have taken place on the coast-line. Standing as it does amid stormy seas and rapid tidal currents, Britain has for ages suffered much from the attacks of the ocean. More especially has the loss of land fallen along our eastern shores. Ever since the submergence of the North Sea and the cutting through of the Strait of Dover, the soft rocks that form our sea-board facing the mainland of Europe have been a prey to the restless waves. Within the last few centuries whole parishes, with their manors, farms, hamlets, villages, and churches have been washed away; and the fisherman now casts his nets and baits his lines where his forefathers ploughed their fields and delved their gardens. And the destruction still goes on. In some places a breadth of as much as five 
yards is washed away in a single year. Holderness, once a wide and populous district, is losing a strip of ground about two and a quarter yards broad, or in all about thirty-four acres annually. Its coast-line is computed to have receded between two and three miles since the time of the Romans - a notable amount of change, if we would try to picture what were the area and form of the coast-line of eastern Yorkshire at the beginning of the historic period.

But though the general result of the action of the sea along our eastern border has been destructive, it has not been so everywhere. In sheltered bays and creeks some of the material, washed away from more exposed tracts, is cast ashore again. In this way part of the mud and sand swept from off the cliffs of Holderness is carried southward into the Wash, and is laid down in that wide recess which it is gradually filling up. Along the coasts of Norfolk and Suffolk, inlets which in Roman and later times were navigable channels, and which allowed the ships of the Danish Vikings to penetrate far into the interior of the country, are now effaced. On the shores of Kent, also, wide tracts of low land have been gained from the sea. Islands, between which and the shore Roman galleys and Saxon war-boats made their way, are now, like the Isle of Thanet, joined to the mainland. Harbours and towns, such as Sandwich, Richborough, Winchelsea, Pevensey, and Porchester, which once stood at the edge of the sea, are now, in some cases, three miles inland. There appears also to have been some gain of land on parts of the south coast of Sussex, whereby the 
physical geography of that district has been considerably altered. The valleys by which the downs are there trenched were formerly filled with tidal waters, so that the ancient camps, perched so conspicuously on the crest of the heights, could not communicate directly with each other except by boat. Instead of being a connected chain of fortifications, as was once supposed, they must have been independent strongholds, surrounded by water on three sides, and on the north by dense forest and impassable morasses.

The subterranean forces which throughout geological time have been so potent in the area of the British Isles, appear to have on the whole remained nearly quiescent during the centuries of authentic history. Volcanic energy, which played so notable a part throughout most of the geological past of our region, has never awakened here since the remote Tertiary ages, but has shifted its site northwards to Iceland, where it continued its activity even during the Ice-Age and has remained vigorous down to the present time. But two forms of underground movement have affected Britain since man appeared here. In the first place, there have been important changes in the relative levels of sea and land, and in the second place, the islands have frequently been shaken more or less perceptibly by earthquakes.

In southern Scotland, the north of England and of Ireland, the land has been upraised some twenty feet or more. As a consequence of this elevation a selvage of flat alluvial land has been added to a number of the estuaries, particularly to those of the Forth, Tay and Clyde. Canoes and other remains of human 
workmanship, found imbedded in the sands and silts of this marine terrace, show that the upheaval has taken place since some part of Neolithic time. The addition of these strips of level ground to the margin of the land has had an important influence on the human population of these districts, for it has provided many hundreds of square miles of arable ground, comprising admirable sites for dozens of villages and towns as well as for excellent coast-roads.

On the other hand, a long tract of land, extending from Cork across the Bristol Channel and the southern counties to the coast of Yorkshire, has sunk fifty feet or more since the Neolithic period. The result of this depression has been to allow the sea to ascend far up many of the estuaries which had previously been rivervalleys, and thus to create, or at least to deepen and widen, the numerous natural harbours which indent the south coasts of England, Wales and Ireland. Not improbably the downward movement, by helping to lower the narrow isthmus which in the earlier ages of the human period connected Kent with the north-west of France, contributed not a little to the insulation of England from the continent.

Earthquake-shocks, though generally feeble, have been of severity enough to damage public buildings. The cathedral of St. David's in its uneven floor and dislocated walls, still bears witness to the shock which six hundred years ago did so much injury to the churches of the west of England. But though a formidable catalogue has been drawn up of the earthquakes experienced within the limits of these islands, it is not to that kind of underground disturbance that 
much permanent alteration of the surface of the country is to be attributed.

In fine, there can be no doubt that the larger features of the landscape of Britain have mainly determined the distribution of the several tribes of mankind out of which the present population of our islands has grown. It is hardly less obvious that the same features have continued during the times of history to influence the development and progress of these tribes. The Gael who long ages ago was pushed by the Briton into the mountain fastnesses of the north was left there to maintain, until only a few generations ago, his primitive habits as hunter and warrior, cattle-dealer and freebooter. While he remained comparatively unprogressive, the Norsemen, Danes and Saxons, who took possession of the lowlands that lay between his glens and the sea, were able to advance in agriculture upon richer soil and in a less inhospitable climate, and to crowd the land with their homesteads, farms, villages, towns and seaports. So too the Welshman, pushed in turn into his hills by successive Teutonic swarms from the other side of the North Sea, has preserved his pristine language, and with it much of that individuality of character which has kept him from cordially amalgamating with the invaders. And thus while the original Celtic people, restricted to less ample territories and less fertile land, have to a large extent retained the holdings and habits of their ancestors, building comparatively few towns, and engaging in few crafts, save farming and stock-raising, the Teutonic tribes, possessing themselves of the broad culti- 
vable lowlands and the great repositories of coal and iron, have thrown across the islands a network of thoroughfares, have scattered everywhere villages and towns, have built many great cities, have developed the industrial resources of the land and have mainly contributed to the commercial supremacy of the Empire.

While the leading elements of the topography have remained for many long ages essentially the same, there have arisen since the beginnings of history, many important minor changes in the landscape, mainly due to human interference, whereby the progress of the population has been more or less affected. Prominent among these changes has been the clearing of the dense woodlands that once covered so large a proportion of the surface. Innumerable bogs and fens have been drained and converted into arable land; lakes have been silted up by natural causes or have been emptied by artificial drainage. War has been waged against the wild animals which once abounded all over the islands. The bear, wolf and wild boar have been extirpated. Only a few of the smaller beasts of prey have been allowed to survive in diminished numbers. The various species of deer would long ago have been exterminated had they not been preserved as game.

But man's influence on the landscape has not consisted wholly in removing what he found to be obnoxious. He has introduced many forms of vegetation among those indigenous to the country. $\mathrm{He}$ has thus converted thousands of square miles of scrub, moor and woodland into gardens, parks, meadows 
and corn-fields. He has replaced some parts of the primeval forest by plantations of a different type, wherein the native hardwood trees are mingled now with larch, silver-fir and other trees which seem to have had no place in the original flora.

But the minor modifications of the landscape within historic time have not been merely those due to human interference. Nature has been ceaselessly at work in slowly, and for the most part imperceptibly, changing the forms of the ground. The streams have dug their channels deeper into the flanks of the hills and have spread their alluvial soil further and wider over the valleys and lake-floors. The frosts of winter have been splintering the crags, the springs have been sapping, the cliffs, and from time to time landslips have been launched into the streamchannels below. The sea has cut away large slices of land from some parts of the coast-line, while to others it has added strips of alluvial ground and mounds of shingle. We have seen too that underground movements have contributed to modify the landscape in some parts of the country, certain tracts having been upraised so as to expose broad spaces of flat ground, while others have been submerged beneath the sea which now ascends into what were formerly open valleys. This sinking of the land in southern England, inasmuch as it helped to separate Britain from the continent, must be regarded as probably the most far-reaching change that has affected the landscape of this country since the days of Neolithic man. 


\section{Landscape and the Imagination ${ }^{1}$}

THE more marked features on the surface of the land have from early times awakened the curiosity and stimulated the imagination of men. Mountainous regions with their peaks and crests, where cloud and tempest find a home, their rugged scarps of cliff nd crag, whence landslips sweep down into the valleys, their snows and frosts, their floods and avalanches, their oft-repeated and too frequently disastrous shocks of earthquake, supply the most striking illustrations of this relation of the external world. Yet while it is from these elevated parts of the earth's surface, where the activities of nature seem to beat with a more rapid pulse, that the human imagination has been more especially stimulated, even among the comparatively featureless lowlands the influence of outer things, though less potent, may be distinctly traced. Wherever, for instance, the monotony of a lowland landscape is broken by an occasional oddly-shaped hill, by a conspicuous grassy mound, by a group of prominent boulders, by a cauldron-shaped hollow, or by

${ }^{1}$ Fortnightly Review, April, 1893. 
a river chasm, we may expect to find that these diversities of scenery have from time immemorial arrested attention.

Whatever departs from ordinary usage and experience prompts, even among the rudest people, a desire for explanation. The more striking elements of topography accordingly aroused the curiosity of the earliest races who came to dwell among them, and to whom, in the infancy of the world, the forces of nature were more or less mysterious. These forces were then looked upon as visible manifestations of the agency of superior beings, whose conflicts or co-operation were held to account for the changes of external nature. Thus, by a system of personification that varied from clime to clime, primeval mankind surrounded itself with invisible deities, to each of whom some special function in the general government and progress of the world was assigned.

Hence the problems presented by the more impressive details of the scenery of the earth's surface were in truth among the earliest with which the human race began to deal. If we try to discover how they were first approached, and how their treatment varied, not only with peculiarities of race and national temperament, but with conditions of climate and variations of topography, we are led backward into the study of some of the most venerable efforts of the human imagination, which, though now in large measure faded or vanished, may yet be in some slight degree recovered from the oldest mythologies and superstitions. In many of the earlier myths we may recognise primitive attempts to account for some of the 


\section{LANDSCAPE AND IMAGINATION}

more prominent features of landscape or of climate. And as we trace the variations of these legends from country to country, we learn how much their changes of dress have arisen from local peculiarities of environment.

Of the earlier interpretations of nature, some may be partially restored from a comparison of ancient myth and superstition with the physical characters of the regions wherein these legends took their rise, or where, at least, they assumed the forms in which they have been transmitted to later ages. Others have survived in place-names which, still in common use, connect our own generation with the days of our ancestors.

In pursuing the investigation of this subject we soon perceive that the supernatural interpretations, and the tendency to personification which led to them, began eventually to be supplanted by natural explanations founded on actual observation of the outer world, and that this change of view, commencing first with the few observant men or philosophers, made considerable way among even the ordinary populace, long before the decay of the mythological systems or superstitions of which these primeval supernatural interpretations formed a characteristic part. The growth of the naturalistic spirit was exceedingly slow, and for many centuries was coeval with the continued vigorous life of religious beliefs which accounted for many natural events as evidence of the operations of supernatural beings.

Those features of the outer world which most attract attention were the first that appealed to the observing 
faculty of mankind. Among them the elements of topography obviously hold a foremost place, including, as they do, the most frequent and impressive manifestations of those natural agencies whereby the surface of the land is constantly modified. It was impossible that after men had begun to observe, and to connect effects with causes, they should refrain from referring the resultant changes of landscape to the working of the natural processes that were seen or inferred to produce them. They were led to trace this connection even while their religious belief or superstition remained hardly impaired. The conclusions thus popularly reached were sometimes far from correct, but inasmuch as they substituted natural for supernatural causes, they undoubtedly marked a distinct forward step in the intellectual development of man.

From that time onward the influence of scenery on the human imagination took a different course. The gods were dethroned, and the invisible spirits of nature no longer found worshippers; but it was impossible that the natural features which had prompted the primeval beliefs should cease to exercise a potent influence on the minds of men. This influence has varied in degree and in character from generation to generation, as we may see by comparing its place in the literature of successive periods. Probably at no time has it been more potent than it is at the present day.

To discuss fully this wide subject would demand far more space than can be given to it here. I propose, therefore, to select two portions of it only; one from the beginning and the other from the end 


\section{LANDSCAPE AND IMAGINATION}

of its historical development. I shall try to show first, by reference to primitive myth and legend what were the earliest and most obvious effects of prominent elements of topography on the imagination, and secondly, what these effects are or should be now in the midst of modern science and universal education.

The mythology of Ancient Greece supplies many illustrations of the way in which the physical aspects of the land have impressed their character on the religious beliefs and superstitions of a people. The surface of that country is almost everywhere rugged, rising into groups of bare, rocky hills and into chains of lofty mountains which separate and enclose isolated plains and valleys. The climate embraces all the softness of the Mediterranean shores, together with the year-long snows and frosts of Olympus on the one hand, and the almost sub-tropical heat of the lowlands of Attica on the other. The clouds and rains of the mountains have draped the slopes with umbrageous forests, and have spread over the plains a fertile soil which has been cultivated since before the dawn of history. Thus, while a luxuriant vegetation clothes the lower grounds with beauty, bare crags and crests are never far away. The soft and the harsh of nature, the soothing and the repulsive, are placed side by side. The indolence begotten of a teeming soil and sunny clime is quickened by proximity to the stern mountain-world-the home of thunder-clouds, tempests, and earthquakes. In the childhood of mankind, the physical features of such a country could not fail to react powerfully upon the imagination of those who dwelt among 
them, calling forth visions of grace and beauty, and at the same time imparting to these visions a variety and vigour which would hardly have been developed among the dwellers on monotonous plains. The natural influence of scenery and climate like those of Greece upon the imagination of a race endowed with a large share of the poetic faculty has never been more forcibly or gracefully expressed than by our own Wordsworth, in a well-known passage in the fourth book of his Excursion.

With the source of the early Hellenic myths we are not so much concerned in the present inquiry as with the form in which they have reached us. Whether they arose in Greece, or, having been brought from some other home, received their final shape there, is of less moment than the actual guise in which we find them in the earliest Greek literature. There cannot, I think, be any doubt that to the striking topography of Thessaly they are largely indebted for the dress in which they appear in the poems of Homer and Hesiod. We may recognise among them some of the earliest recorded efforts of the human imagination to interpret the aspects of nature, and these aspects were unmistakably such as presented themselves in that particular portion of the ancient world.

The wide Thessalian plain, the largest area of lowland in Greece, lies upon Cretaceous and Tertiary rocks, which, in the lower parts of the region, are overlain with a level tract of alluvial soil. Round this plain stretches a girdle of lofty and imposing mountains, composed chiefly of hard crystalline schists 


\section{LANDSCAPE AND IMAGINATION}

and limestones. On the north the crags and snowy crests of Olympus rise high and bare above the dense forests that clothe their slopes. To the eastward, above the narrow chasm of Tempe, through which the drainage of the great inland basin escapes to the sea, the grey peak of Ossa forms the northern end of a long chain of heights which, farther south, mount into the ridge of Pelion. Along the southern edge of the plain another vast mountain barrier sweeps eastward from Mount Pindus through the lofty chain of Othrys to the sea.

No other part of Greece presents such diversities of topography and of climate as are to be found within the region thus encircled with mountains. The peaceful beauty and spontaneous fertility of the plain offer an impressive contrast to the barren ruggedness of the surrounding heights. High above the gardens, meadows, and corn-fields, sharply-cut walls and pinnacles of white limestone mount out of the thick woodland into the clear upper air. Nor is evidence wanting of those catastrophes which from time to time convulse a mountain region. At the base of the bare cliffs and down the rocky declivities lie huge blocks of stone that have been detached by the weather from the precipices above. And, doubtless, from time immemorial the dwellers on these slopes have been familiar with the crash and tumult of the landslip, and with the havoc wrought by it on forest and field. Along the mountain-ridges, too, clouds are ever gathering, and thunderstorms are of continual recurrence. The lightnings of Olympus are visible from Othrys, and to the inhabitants of the 
intervening plain the incessant peals and reverberations from the northern and southern ranges might well sound like shouts of mutual defiance from the two lines of lofty rampart, as where, in a more northern clime

"Jura answers from her misty shroud Back to the joyous Alps that call to her aloud."

If to these daily or frequently returning meteorological phenomena we add the terrors of occasional earthquakes, such as affect most mountainous countries and are known to have convulsed different parts of Greece within historic times, we perceive how favourable the conditions of environment must have been for exciting the imagination of an impressionable people. Whether, therefore, the early Hellenic myths arose in Hellas, or came from elsewhere, they could hardly fail in the end to betray the influence of the surroundings amid which they were handed down from generation to generation. The snowy summits of Olympus, rising serenely above the shifting clouds into the calm, clear, blue heaven, naturally came to be regarded as the fit abode of the gods who ruled the world. The association of that mountain-top with the dwelling-place of the immortals, first suggested to the imagination of the early settlers in Thessaly, passed outwards to the utmost bounds of the Hellenic world. Everywhere the word Olympus came to be synonymous with heaven itself.

In the myth of the Gods and the Titans, as handed down in early Greek poetry, the influence of Thessalian topography is abundantly conspicuous. The two 


\section{LANDSCAPE AND IMAGINA'TION}

opposite mountain ranges of Olympus and Othrys became the respective strongholds of the opposing hosts. The convulsions of that ten years' struggle, whether suggested or not by the broken features of the ground and the conflicts of the elements, assuredly took their poetic colouring from them. The riven crags piled in confusion one above another, the rock-strewn slopes, the trees uprooted by landslips, the thunder-peals that resound from the misty mountain-chains, seem still to tell of that primeval belief, wherein the Titans were pictured as striving with frantic efforts to scale the heights of Olympus by piling Ossa on Pelion, hurling huge rocks and trees through the darkened air, and answering the thunderbolts of Zeus with fierce peals from the clouds of their lofty citadel. In the magnificent description of Hesiod, beneath all the supernatural turmoil we catch, as it were, the tumult of a wild storm among the Thessalian hills, with such added horrors as might be suggested to the imagination of the poet from the recollection or tradition of former earthquake or volcanic eruption.

Long after the time of the primitive mythology, the more striking features of the land continued to appeal to the Hellenic imagination and to perpetuate the prowess of gods and heroes, even down to generations of men among whom belief in these legends was already beginning to grow dim. The narrow gorge of Tempe may be cited in illustration of this influence. Cleft between the precipices of Olympus and Ossa, and serving as the only outlet for the drainage of the wide Thessalian plain, this chasm must have arrested the attention of the earliest settlers, 
and certainly continued for many centuries to be one of the most noted valleys of the Old World. The contrast between the vast level plain through which the River Peneius and its tributaries wander, and the narrow gorge through which the accumulated waters issue; the apparently insurmountable barrier interposed across the course of the stream; the singular and unexpected ravine by which the drainage is allowed to escape to the sea; the naked, fissured walls of white limestone on either side of the narrow pass, even now powerfully impress the observant traveller of to-day.

These striking features could not fail to appeal to the imagination of the old Greek. From early times it was recognised that the plain of Thessaly had once been covered with a sheet of water, of which the remaining portions formed two considerable lakes. Had no passage been opened for the outflow of the drainage across the barrier of mountains the plain would have remained submerged. The cleaving of a chasm whereby the pent-up waters were allowed to flow down to the sea, and thus to lay bare so wide an area of rich land for human occupation, was looked on as the work of some benevolent power, and naturally came to be associated with the name of Poseidon, the God of the Sea. ${ }^{1}$ In later times, when the deeds of gods and heroes began to be confounded with each other, the supernatural character of the Vale of Tempe was still acknowledged; but the opening of the cleft was in course of time transferred to Hercules, who, by cutting a hollow

1 Herodotus, vii. 129. 


\section{LANDSCAPE AND IMAGINATION}

across the ridge, allowed the stagnant waters of the interior to flow off into the sea. ${ }^{1}$

Prominent hills and crags in other parts of Greece gave rise to legends, or became the localised scenes of myths which had floated down from an older time, and sometimes perhaps from another birthplace. Thus the hill Lycabettus, that stands so picturesquely on the north-east of Athens, suggested to the lively fancy of the early Athenians a record of the prowess of their patron-goddess. When Athene, so the legend ran, was founding their state and wished to strengthen the city, she went out to Pallene, a demos lying to the north-eastward, and procured there a great hill which she meant to place as a bulwark in front of the Acropolis, but on her way back, hearing from a crow of the birth of Erichthonius, she dropped the hill, which has remained on the same spot ever since. Legends of this kind, but varying in dress with local topography and national temperament, may be found all over the world.

To the early Greeks the West was a region of marvels. It lay on the outermost bounds of the known world, where the sun descended beneath the earth and where Atlas supported the vault of Heaven. By degrees as the spirit of colonisation drew men in that direction, the occidental marvels of the first voyagers faded away before a more accurate knowledge of the Mediterranean shores. But the legends to which they had given rise remained in the popular mythology, and served as subjects for chroniclers and poets.

${ }^{1}$ Diod. Sic., iv. 18. See also Lucan, Pharsalia, vi. 345. 
Thus the two singular masses of rock in which, at Gibraltar and Ceuta, the European and African continents respectively terminate, and which form, on each side of an intervening strait, only some seventeen miles wide, a kind of gateway for the vast Mediterranean basin, naturally fixed the attention of the early navigators on those distant waters, and filled a prominent place among the travellers' tales from the remote West. They took their part in the myths, becoming the 'pillars of Hercules,' that were erected by this legendary explorer and knight-errant as an eternal record of his labours and of the ultimate limit of his wanderings. The details of the story vary. By some narrators the hero was represented as having narrowed and shallowed the strait, and built his pillars on the two sides to keep the huge monsters of the outer ocean from entering the Mediterranean sea. By others he was believed to have actually excavated the strait itself, and by thus separating Europe and Africa, previously joined together, to have allowed the waters of the ocean and those of the inner sea to mingle. ${ }^{1}$

In a mountainous country, where the streams, swollen by sudden or heavy rains, sweep down much detritus into the valleys and plains, the great changes of topography thereby produced impress the imagination and dwell in the memory of the inhabitants. In Greece, the myths that gathered round the Achelous-the largest and most famous river in the country-probably arose, as Strabo showed, from

${ }^{1}$ Diod. Sic., iv. 18, who allows his readers to choose which version of the legend they prefer. 


\section{LANDSCAPE AND IMAGINATION}

the varying operations of the stream itself. The stories of the river-god assuming the form of a bull and of a serpent, his contests with Hercules, and the loss of his horn, are obviously only personifications of a rapid stream, rushing impetuously from its mountainous birthplace and winding in twisted curves across the plain; now strewing the meadows with gravel, now curbed by the laborious construction of embankments, and now bursting forth again to resume its old wayward course. ${ }^{1}$ The river still retains the character which prompted its ancient legends. It is now called the Aspropotamo or white river, from the abundance of white silt suspended in its water and lying on its bed. While in winter, fed by the rains and melting snows of distant Pindus, it often fills its channel from bank to bank, it shrinks in summer into a number of lesser streams, which wind about in a broad gravelly channel.

In the myths that grew round other rivers of ancient Greece, we may recognise similar early attempts to account for striking features of local typography. When, for instance, Hercules is fabled to have barred back the river Cephissus and to have submerged and destroyed the country about Orchomenos in Bœotia, ${ }^{2}$ we may doubtless recognise the traditional record of some prehistoric inundation, perhaps an abnormal rise of the singularly variable Lake Copais, whereby a

${ }^{1}$ See Strabo, x. 458. Diodorus also (iv. 35), giving a similar interpretation of the legends, tells us how Hercules hollowed out a new bed for the Achelous, thereby reclaiming a vast tract of exceedingly fertile land.

2 Diod. Sic., iv. 18. 
large tract of land was flooded; possibly even an attempt to account for the lake itself.

But there was one physical feature which, more than any other, must have impressed the imagination of the dwellers by the Mediterranean shores; and that was furnished by the volcanic phenomena so characteristic of the great depression between Europe and Africa. Among the islands of the Egean sea, some were continually smoking; others retained, in their cindery cones and ashy slopes, the memorials of subterranean fires not long extinguished. From time to time actual eruptions broke forth, with their accompaniments of convulsion and terror. We know from geological evidence that one of the most violent volcanic explosions which have affected the Mediterranean basin took place where now is the island of Santorin, after the original site was inhabited by a civilised people. ${ }^{1}$ A conical volcanic mountain-an eastern Vesuvius or Etna-stood on that site, but in some prehistoric age it was blown into the air, as happened at Krakatoa in August, I 883, only portions of the base of the cone being left to form the present semi-circular ring of islands. Whether this stupendous catastrophe occurred after the Hellenic race appeared in the Ægean area has not been determined. But the tradition of it may have lingered in the district, down to the time when, about two hundred years B.C., a new volcano rose from the sea in the centre of this group of islands. Another marked eruption occurred in the year 46 в.c. Even in our own day, this ancient vent has shown renewed activity,

${ }^{1}$ Fouqué, Santorin et ses Eruptions, chap. iii. 


\section{LANDSCAPE AND IMAGINATION}

fresh eruptions have taken place from the middle of the engulphed crater, and another central volcanic cone is gradually rising there.

The Greeks, thus accustomed to volcanic phenomena among their own islands, were prepared to accept the stories, brought to them from the remote West, of far more colossal volcanoes, and more gigantic and continuous eruptions. Like the accounts of other physical phenomena imported from that distant and half mythical region, the tales of the volcanoes were no doubt at first more or less exaggerated. The adventurous voyagers who, sailing as far as Sicily and the Æolian Islands, saw the noble snow-capped cone of Etna, loftier than the mountains of Hellas, yet emitting smoke by day and a glare of fire by night; who watched Stromboli continually in eruption; who perchance beheld the land convulsed with earthquakes, the air darkened with volcanic dust, the sea covered with floating cinders, and who only with much effort were able to steer their vessels into opener water, would bear eastward with them such tales of horror as would not fail to confirm and increase the popular belief in the national mythology, and might even suggest new myths or new versions of those already current. The greater size and vigour of the volcanoes would tend to create the impression that other characteristics of the region were on a similarly exaggerated scale. Sicily was accordingly believed in Homeric times to be the home of a gigantic race of shepherds-the Cyclops.

It is obvious how the legend arose of the hundredarmed giant Typhœus or Enceladus, who was fabled 
to lie buried beneath the region between Etna and the Phlegræan Fields. The belching of the volcano suggested to the popular imagination, which so loved to personify the powers of nature, the gasping of an imprisoned monster. The tremors so constantly affecting the islands were his quiverings as he lay on his uneasy, burning bed, and the earthquakes that from time to time shook the region marked how he tried now and again to shift his position there.

As intercourse with the West made the volcanic phenomena of that region more familiar, the mythological interpretation underwent gradual modification. On the one hand, it was observed that eruptions from Etna, sometimes disastrous enough when they occurred, took place at irregular and often widely separated intervals. On the other hand, it was noticed that among the Æolian Islands, which lay to the north, within sight of the Sicilian volcano, subterranean rumblings and explosions were of daily occurrence. The Cyclops of older time, being no longer extant above ground, came to be transferred in popular fancy to the underground regions as associates of Hephaistos or Vulcan. The incessant commotion below the surface suggested the idea of a subterranean workshop, where these beings were employed in forging the thunderbolts of Jove and in making arms and implements for other gods and heroes. Accordingly the belief gradually spread over the ancient world that the god of fire had his abode under Sicily and the neighbouring islands.

Further, the abundant discharges of steam and vapours, both in the quiescent and the active phases 


\section{LANDSCAPE AND IMAGINATION}

of volcanic eruptivity, suggested that somehow they were due to wind imprisoned within the earth, and led to the myth which represented the god of the winds as having his home in the same subterranean caverns.

It has often occurred to me that one phenomenon, connecting the meteorological conditions of the atmosphere with the volcanic activity of the Æolian Islands, which must have early attracted attention, would not improbably react on mythological beliefs in that part of the Mediterranean basin. Though continually in a state of eruption, Stromboli is said to be more especially active when atmospheric pressure is low. Its clouds of steam and discharges of stones are most marked before or during stormy weather, and are consequently more conspicuous in winter and spring than in summer and autumn. Since the days of Polybius and Strabo, the fishermen of the region have regarded the cloud-cap of that volcanic cone as a trustworthy indication of the kind of weather to be expected.

In Roman times, this increase of subterranean excitement in the early part of the year appears to have received a supernatural interpretation. It was looked on as evidence that at that season Vulcan and his Cyclops were specially busy over their furnaces, forging the thunderbolts that the Father of Gods and men was to use during the ensuing summer. Thus Horace, when joyously enumerating to his friend L. Sextius the signs that winter is giving way to spring-the disappearance of ice and hoar-frost, the coming of the balmy west wind, the release of the cattle from their stalls and of the farmer from his fireside, the advent of the goddess of love, and the dances of the 
nymphs and graces under the bright moon-adds that now is the time

\section{'When fiery Vulcan lights anew \\ The Cyclops' glowing forge.'}

Long before these fables had ceased to be tacitly accepted by the people, they had begun to be rejected by the more thoughtful men in the community. There slowly grew up a belief in the settled and continuous sequence of nature. ${ }^{2}$ In the midst of the schemes that were devised for explaining the old myths or making them fit into the widening experience of later ages, we may detect the dawn of the scientific spirit. Observant men were now able to recognise that what had been regarded by their grandfathers as evidence of supernatural agency, might well have been produced by natural and familiar processes of change. The early geographers afford us some interesting illustrations of the growth of this naturalism. Thus, Herodotus, in his excellent description of the physical geography of Thessaly, takes occasion, as a man of his reverent spirit naturally would, to mention the popular belief that the striking gorge of Tempe had been rent open by a blow from the trident of Poseidon. He admits the likelihood of the explanation, but immediately proceeds to state his opinion that the formation of this defile was not an abnormal manifestation of divine power, but was to be regarded as an example of the ordinary system of the world.

${ }^{1}$ Carm. I., iv. 7 .

${ }^{2}$ See this subject fully discussed by Grote, History of Greece, vol. i. 


\section{LANDSCAPE AND IMAGINATION}

'Whoever believes,' he says, 'that Poseidon causes earthquakes and rents in the earth will recognise his handiwork in the vale of Tempe. It certainly appeared to me to be quite evident that the mountains had been there torn asunder by an earthquake.'

Coming down some four centuries later we find that in Strabo, while all allusion to the supernatural has disappeared, the formation of the topography by natural causes is described with as much confidence as if the events were vouched for by documentary evidence. 'When the present chasm of Tempe,' he remarks, 'was opened by the shocks of an earthquake, and Ossa was torn away from Olympus, the Peneius flowed out through this passage to the sea, and thereby drained the interior of the country.' ${ }^{2}$ He speaks also of the two lakes Nessonis and Bœbeis as remnants of the large sheet of water which had originally covered the lowlands of Thessaly.

The myths and legends of the Teutonic races supply many illustrations of primitive attempts to account for some of the more striking external phenomena of nature. In comparing these interpretations with those of the Greeks, we cannot fail to perceive the influence of the different scenery and climate amid which they took their birth. The dwellers in the west of Scandinavia spent their lives under the shadow of lofty, rugged fjelds, surmounted by vast plains of snow. They were familiar with the gleam of glaciers, the crash of ice-falls, the tumult of avalanches. Cloud and mist enshrouded them for weeks together. Heavy rains from the broad Atlantic swelled their 
torrents and waterfalls. Out of the dark forests, the naked rock rose in endless fantastic and suggestive shapes. The valleys were strewn with blocks of every size detached from the cliffs above. Mounds of earth and stones, like huge graves, mottled the lower grounds over which they had been dropped by old glaciers and ice-sheets. It was a region difficult of access and hard to traverse, stern and forbidding in aspect, abounding in gigantic, fantastic, and uncouth features, while the harshness of its topography was but little tempered by that atmospheric softness which sometimes veils the rocky nakedness of sunnier climes.

Away from the great mountain-tracts of Norway, though the topography was on a diminished scale, there were many features similar in kind, and fitted to awaken like fancies in the minds of those who dwelt among them. The hill groups that rise out of the great Germanic plain, such as the Hartz and the detached heights of central Scotland, though far less imposing than the Scandinavian fjelds abound nevertheless in picturesque details. Along the sides of their cliffs, especially in the narrow valleys by which they are traversed, crags and pinnacles of odd and often imitative shapes rise one above another. Solitary boulders, unlike any of the rocks around, are strewn over the hills and scattered far across the plains. Green, grassy mounds, like gigantic earthworks, or groups of sepulchral tumuli, stand conspicuously on the bare heathy moors. And when to these singular natural features there is added the strangely impressive influence of the clouds, mists, and other meteorological conditions that mark the changeful climate of western 


\section{LANDSCAPE AND IMAGINATION}

Europe, we are presented with such a combination of effective causes as might well stimulate the fancy of an imaginative people, and might, among the members of the great Teutonic family, evoke feelings and superstitions not less characteristic than those of ancient Greece.

The grandeur and ruggedness of the scenery of these western and northern European countries, and the frequent sombreness of the climate are faithfully reflected in the prevalent Teutonic myths and superstitions. Thor and his mallet found a congenial home among the Scandinavian mountains and fjords. There, too, was the appropriate haunt of the Frost-giants. The race of giants, with their fondness for stones and rocks, to whom so much influence in altering the external aspects of nature was ascribed by the Teutonic races, might have had their ancestral abode among the crags and defiles of the north-west, but they readily naturalised themselves among the less rugged tracts of northern Germany and of Britain. The dwarfs, trolls, fairies, and hill-folk who, whether or not they are to be regarded as representatives of a diminutive human population that originally inhabited those regions, were believed to dwell under the earth and in caves, and who were regarded as having played a distinct though subordinate part in changing the surface of the land, would find appropriate haunts wherever the Teutons established themselves. The personification of natural forces and the effects produced by the supernatural beings so pictured to the imagination, certainly bear a marked family likeness all over the west and northwest of Europe. 
There is, moreover, one feature that distinguishes the myths and legends of those northern lands-the grim humour which so often lights them up. The grotesque contours of many craggy slopes where, in the upstanding pinnacles of naked rock, an active imagination sees forms of men and of animals in endless whimsical repetitions, may sometimes have suggested the particular form of the ludicrous which appears in the popular legend. But the natural instinct of humour which saw physical features in a comical light, and threw a playful human interest over the whole face of nature, was a distinctively Teutonic characteristic.

A few examples from the abundant collection that might be gathered must here suffice. Some of the most singular features of the landscapes of the northwest of Europe arise from the operations of the ice-sheets, glaciers, and icebergs of that comparatively late geological period to which the name of the Ice Age is given. The perched boulders which stand poised near the verge of cliffs or scattered over the sides and summits of hills, everywhere suggested the working of supernatural agency. In some districts they were looked upon as missiles hurled by giants who fought against each other. In others, they were regarded as the work of giantesses, or 'auld wives,' as they were called in Scotland, who to exhibit their prowess would transport masses of rock as large as hills from one part of the country to another.

This capacity in such supernatural beings to carry huge burdens of stone or earth has furnished an explanation of many islands and mounds along the maritime 


\section{0

parts of Britain and the countries bordering the Baltic Sea. Ailsa Craig, that stands so picturesquely in the middle of the Firth of Clyde, was the handiwork of a carline, who, for some object which is not very clear, undertook to carry a huge hill from Scotland to Ireland. Before she had got half-way over, her apron-strings broke and the rock fell into the sea, whence it has projected ever since as the well-known island. In proof of the legend a hollow among the Carrick hills is pointed out as the place from which the mass of rock was removed.

Along the Baltic coasts many similar tales are told. Thus the island of Hven was dropped where it stands by the giantess Hvenild, who wished to carry some pieces of Zealand over to the south of Sweden. Sex seems to have counted for little in the nature or amount of work accomplished, for witches and warlocks, giants and giantesses, were equally popular and equally powerful. A mighty giant in the Isle of Rugen, vexed that, as his home stood on an island, he had always to wade from it when he wished to cross over to Pomerania, resolved to make a causeway for his greater convenience. So, filling his apron with earth, he proceeded to carry out his purpose, but soon the weight of his burden broke an opening in the apron, and such a quantity of stuff fell out as to form the nine hills of Rambin. Stopping the hole, however, he went on until another bigger rent was torn open, from which earth enough tumbled to the ground to make thirteen of the other little hills that now appear in that district. But he succeeded at last in reaching the sea with just enough of earth left in the apron to enable him to make the 


\section{TOPOGRAPHICAL MY'THS}

promontory of Prosnitz Hook and the peninsula of Drigge. There still remained, however, a narrow passage between Pomerania and Rugen which he had no material left to bridge over, and so in a fit of rage and vexation he fell dead, and his undertaking still remains incomplete. ${ }^{1}$ The geologist who has studied the singular forms and distribution of the 'glacial drift' can best appreciate this and similar attempts to account for the shapes and grouping of these still enigmatical mounds and ridges.

The progress of Christianity extirpated the pagan gods and giants, but failed to destroy the instinctive craving after a supernatural origin for striking physical features. This surviving popular demand consequently led to gradual modification of the older legends. In Catholic countries the deeds of prowess were not infrequently transferred to the hands of the Virgin or of saints. Thus at Saintfort, in the Charente region, a huge stone that lies by the river Ney is said to mark where the Virgin dropped from her apron one of four pillars which she was carrying across. In Britain, and especially in Scotland, the devil of the Christian faith appears to have in large measure supplanted the warlocks and carlines of the earlier beliefs, or at least to have worked in league with them as their chief. All over the country 'devil's punchbowls,' 'devil's cauldrons,' 'devil's bridges' and other names mark how his prowess has been invoked to account for natural features which in those days were deemed to require some more than ordinary agency for their production. $\checkmark$ These popular efforts to explain physical phenomena

1 See Grimm's Deutsche Mythologie, i. 502. 


\section{LANDSCAPE AND IMAGINATION}

which, from the earliest days of human experience, have appealed most forcibly to the imagination, have survived longest in the more rugged and remote regions, partly, no doubt, because these regions have lain furthest away from the main onward stream of human progress, but partly also because it is there that the most impressive topographical features exist. The natural influence of mountain-scenery upon the mind is probably of an awe-inspiring, depressing kind. We all remember the eloquent language in which Mr. Ruskin depicts what he calls the 'mountain gloom.' Man feels his littleness face to face with the mighty elemental forces that have found there their dwellingplace. Even so near our own time as the later decades of the eighteenth century men of culture could hardly find language strong enough to paint the horrors of that repulsive mountain-world into which they ventured with some misgivings, and from which they escaped with undisguised satisfaction. After we have made every allowance for the physical discomforts inseparable from such journeys at that time, when neither practicable roads nor decent inns had been built, it is clear that mountain-scenery not only had no charm for intelligent and observant men, but filled them with actual disgust. Not until the nineteenth century did these landscapes come into vogue with ordinary sightseers. Only within the last two or three generations have mountains begun to attract a vastly larger annual band of appreciative pilgrims than ever crowded along what used to be called the 'grand tour.' For this happy change we are largely indebted to the Alpine ascents and admirable descriptions of the illustrious De 


\section{POPULAR THEORIES}

Saussure on the Continent, and to the poetry of Scott and Wordsworth in this country.

It is interesting to inquire how, after the popular feeling has thus been so entirely transformed, mountainous scenery now affects the imagination of cultivated people who visit it, whether impelled by the mere love of change or by that haunting passion which only the true lover of mountains can feel and appreciate. Even under the entirely changed conditions of modern travel and general education, we can detect the working of the same innate craving for some explanation of the more salient features of mountain-landscape that shall satisfy the imagination. The supernatural has long been discarded in such matters. Even the most unlearned traveller would demand that its place must be taken by scientific observation and inference. But the growth of a belief in the natural origin of all the features of the earth has grown faster than the capacity of science to guide it. Nowhere may the lasting influence of scenery on the imagination be more strikingly recognised than in the vague tentative efforts of the popular mind to apply what it supposes to be scientific method to the elucidation of these more impressive elements of topography. The crudest misconceptions have been started and implicitly accepted, which, though supposed to be based on observation of nature, are in reality hardly less unnatural than the legends of an older time. They have nevertheless gained a large measure of popular acceptance, because they meanwhile satisfy the demands of the imagination.

To the geologist whose duty it is to investigate these 


\section{LANDSCAPE AND IMAGINA'TION}

questions in the calm dry light of science, there is no task more irksome than to combat and dislodge these popular, preconceived opinions, and to procure an honest, intelligent survey of the actual evidence of fact upon which alone a solid judgment of the whole subject can be based. It is not that the evidence is difficult to collect or hard to understand. But so vividly does striking topography still appeal to the imagination, so inveterate has the habit become of linking each sublime result with the working of some stupendous cause, and of choosing in this way what is supposed to be the simplest and grandest solution of a problem, that men will hardly listen to any sober presentation of the facts. They refuse to believe that the interpretation of the earth's surface, like that of its planetary motion, is a physical question which cannot be guessed at or decided a priori, but must be answered by an appeal to the evidence furnished by Nature herself.

For this antagonism geologists are, no doubt, chiefly themselves to blame. While the growth of a love of natural scenery, and especially of that which is lofty and rugged, has been late and slow, the desire to ascertain the origin and history of the various inequalities of surface on which the charms of scenery so largely depend, and by careful scrutiny to refer these inequalities to the operation of the different natural agencies that produced them, has been later and slower still. Men had for several generations explored the rocks that lie beneath their feet, and had, by laborious and patient effort, deciphered the marvellous history of organic and inorganic changes of which these rocks are 


\section{POPULAR THEORIES}

the record, before they seriously set themselves to study the story of the present surface of the land. And thus what was one of the earliest problems to interest mankind has been one of the latest to engage the attention of modern science.

This slowness of development, though it has allowed much misconception to grow up rank and luxuriant, has been attended with one compensating advantage, inasmuch as the various branches of inquiry into which the discussion of the problem resolves itself have made rapid progress in recent years. We are thus in a far better position to enter on a consideration of the subject than we were a generation ago. And though one may still hear a man gravely expounding familiar topographical features much as his grandfather would have done, as if in the meanwhile no thoughtful study had led to a very different interpretation, these popular fallacies, which manifest such vitality, can now be combated with a far wider experience, and a much ampler wealth of illustration from all parts of the globe.

The various elements of a landscape appear to the ordinary eye so simple, so obviously related to each other, and often so clearly and sharply defined, that they are not unnaturally regarded as the effects of some one general operation that acted for their special production; and where they include abrupt features, such as a ravine or a precipice, they are still popularly believed to be in the main the work of some sudden potent force, such as an earthquake or volcanic explosion. There is a general and perfectly intelligible unwillingness to allow that scenery which now appears so complete and connected in all its parts was not the 


\section{LANDSCAPE AND IMAGINATION}

result of one probably sudden or violent cause. Yet the simplest explanation is not always necessarily the correct one. In reality, the problems presented to us by the existing topography of the land, fascinating though they are, become daily more complex, and demand the whole resources of geological science. They cannot be solved by any rough-and-ready process. They involve not only an acquaintance with the recent operations of Nature, but an extensive research into the history of former geological periods. The surface of every country is like a palimpsest which has been written over again and again in different centuries. How it has come to be what it is cannot be told without much patient effort. But every effort that brings us better acquainted with the story of the ground beneath our feet, and at the same time gives an added zest to our enjoyment of the scenery at the surface, is surely worthy to be made.

These remarks lead me naturally to the concluding section of my subject, in which I propose to inquire how far the discoveries of science have affected the relation of scenery to the imagination. It has often been charged against scientific men that the progress of science is distinctly hostile to the cultivation alike of the fancy and of the imagination, and that some of the choicest domains of literature must necessarily grow more and more neglected as life and progress are brought more completely under the sway of continued discovery and invention. We hear these complaints, now in the form of a helpless and hopeless wail, now as an angry and impotent protest. That they are made in good faith, and are often the 


\section{SCIENCE AND POE'TRY}

expression of deep regret and anxious solicitude for the future of some parts of our literature cannot be doubted, and in so far they deserve to be treated by scientific men with hearty respect and sympathy. But is there really anything in the progress of science that is inimical to the cultivation of the imaginative faculty and the fullest blossoming of poetry? The problems of life-truth and error, love and hope, joy and sorrow, toil and rest, peace and war, disease and death, here and hereafter-will be with us always. From the days of Homer they have inspired the sweet singers of each successive generation of men, and they will continue to be the main theme of the poets of the future. As for the outer world in which we live, the more we learn of it the more marvellous does it appear, and the more powerfully does it make its mute appeal to all that is highest and best within us. And, after all, how little have we yet learnt! How small is the sum of all our knowledge! It is still and ever must be true that, in the presence of the Infinite, 'the greater our circle of light, the wider the circumference of darkness that surrounds it.' When the man of letters complains that we have dethroned the old gods, discarded the giants and witches, and erected in their place a system of cold and formal laws that can evoke no enthusiasm, and must repress all poetry, has he never perceived how a true poet can pierce, as our late Laureate could, through mere superficial technicalities into the deeper meaning of things, and can realise and express, in language that appeals to the soul as well as to the ear, the divine harmony and progressive evolution which it is the aim of science 


\section{$5^{8}$ LANDSCAPE AND IMAGINATION}

to reveal? Let me ask such a critic to ponder well the sonnet of Lowell's :

'I grieve not that ripe knowledge takes away The charm that nature to my childhood wore; For, with that insight, cometh, day by day,

A greater bliss than wonder was before:

The real doth not clip the poet's wings;

To win the secret of a weed's plain heart

Reveals some clue to spiritual things,

And stumbling guess becomes firm-footed art.'

It will not, I think, be hard to show that in dissipating the popular misconceptions which have grown up around the question of the origin of scenery, science has put in their place a series of views of nature which appeal infinitely more to the imagination than anything which they supplant. While in no way lessening the effect of human association with landscape, science lifts the veil that hides the past from us, and in every region calls up a succession of visions which, by their contrast with what now presents itself to the eye and by their own unlooked-for marvels, rivet our attention. Scenes long familiar are illumined by 'a light that never was on land or sea.' We view them as if an enchanter's wand were waving over us, and by some strange glamour were blending past and present into one.

Let me try to illustrate these remarks by three examples culled from the scenery of each of the three kingdoms. First, I would transport the reader in imagination to a lonely valley in the far west of the county of Donegal. The morning light is sparkling in diamonds from the dewdrops that cluster on the bent and heather, and is throwing a rainbow sheen 
across each web of gossamer that hangs across our path as we climb the long rough slope in front. Around are bare bleak moorlands, too high and infertile for cultivation, from the sides and hollows of which the peasants dig their fuel. The signs of human occupation grow fewer and fainter as we ascend. The barking of the village dogs and the shouts from the school playground no longer reach our ears. And while we thus retire from the living world of to-day, it almost seems as if we enter into progressively closer communion with the past. Yonder, only a few miles to the north, lies the deep hollow of Glen Columbkill - that western seclusion where tradition records that St. Columba, the great apostle of the Scots, in his earlier years, loved to bury himself for meditation and prayer. Mouldering cross and crumbling cairn, to which latter every pious pilgrim adds a stone, keep his memory green through the centuries. It is with him and his courageous friends and disciples, rather than with sights and sounds of the present time, that we feel ourselves in contact here. And when, high up on this bare mountain-side, we come upon the ruined cells which these devoted men built with their own hands out of the rough stones of the crest, and to which they betook themselves for quiet intercourse with Heaven, amid the wild winds and driving rains of these western hills, the halo of human courage and self-denial falls for us on this solitude to heighten its loneliness and desolation.

Musing on these memories of the past, we find ourselves at last at the top of the slope, nearly two thousand feet above the sea, and discover that from 


\section{LANDSCAPE AND IMAGINATION}

this lofty summit, which is known as Slieve League, the ground plunges down on the other side in a succession of precipices into the Atlantic Ocean, which stretches from the far western horizon up to the very base of the crags beneath our feet. We have in truth been climbing a mountain whereof one-half has been cut away by the sea. What a picture of decay here presents itself! We peer over the verge of the cliffs, still wrapped in their morning shadows, and mark how peak, ridge, and wall of flinty quartzite, glowing in tints of orange, yellow, and red, uprear themselves from the face of the declivity, like the muscles on the limb of some sculptured Hercules, as if the mountain had gathered up its whole strength and knit its frame together to defy the fiercest assaults of the elements. But look how every crag is splintered, how every jutting buttress is rent and creviced, how every ledge is strewn with blocks that have fallen from the naked wall above it! If we detach one of these loosened blocks and set it in downward motion, we may watch it plunge into the abyss, flash from crag to crag, career down the screes of rubbish and make no pause until, if it survive so far, it dashes into the surge below. What we can thus carelessly do in a few moments is done deliberately every winter by the hand of Nature. Slowly but ceaselessly this vast seawall, swept by Atlantic storm, sapped by frost, soaked with rain, dried and beaten by sun and wind, is being battered down under the fire of Nature's resistless artillery.

So far the scene is one that requires no special acquaintance with science for its appreciation. The 
man of literature, who may most disparage the man of science, may well affirm that here they meet on common ground and have equal powers of reception and enjoyment. Nor will he be gainsaid if he claims that for the enjoyment of the distant view he is likewise quite as well equipped as the other. His eye, too, can range over the whole glorious panorama of sea and land, across the wide bay to the hills of Mayo, among which the noble cone of Nephin rises like a distant Vesuvius; southward to the terraced heights of Sligo, with their green tablelands and gleaming cliffs, which look away to the western ocean; eastward and northward, over the billowy sea of hills that stretch through Donegal round again westward to the Atlantic. What is there of note in such -a landscape, he may demand, which he, ignorant of science, misses? What added pleasure, what brighter light, can science cast over it?

By way of reply to these queries, let me ask the reader who has thus far accompanied me to turn from the distant view to what lies beneath his feet on the bare, stony, wind-swept summit of Slieve League. Never shall I forget my own astonishment and enthusiasm when, in company with some of my colleagues of the Geological Survey, I found the splintered slabs of stone lying there to be full of stems of fossil trees, belonging to kinds which occur abundantly in the sandstones below our Coal-measures. The geologist will at once appreciate the full meaning of this discovery. It showed that, perched on the summit of this mountain, some two thousand feet above the sea, lay a cake, only a few acres in extent, of that division of the 


\section{LANDSCAPE AND IMAGINATION}

Carboniferous rocks called the Millstone Grit-a formation which spreads over a large tract of country farther to the east. Here, in the north-west of Ireland, in the very heart of the region of the ancient crystalline schists, and occupying the highest ground of the district, lay a little remnant, which demonstrated that a sheet of Millstone Grit once stretched over that remote part of the island, and may have extended much farther westward over tracts where the Atlantic now rolls. And as the Millstone Grit is followed by the Coal-measures, the further inference could be legitimately drawn that the Irish coal-fields, now so restricted in extent, once spread far and wide over the hills of Donegal, from which they have since been gradually denuded. Truly the woes of Ireland may be traced back to a very early time, when not even the most ardent patriot can lay blame on the invading Saxon.

That little cake of grit on the top of Slieve League stands as a monument of waste so prolonged and so stupendous as to be hardly conceivable. It proves that the north-west of Ireland was buried under a sheet of strata many hundreds of feet thick, and that, inch by inch, this overlying mantle of solid stone has been worn away, until it has been reduced at last to merely a few scattered patches of which that of Slieve League is the most westerly. Not only so, but the present system of hill and valley is thus demonstrated not to be part of the primeval architecture of the earth, but to have come into being after that upper envelope of Carboniferous rock had begun to be removed. What a marvellous series of pictures is thus presented to our imagination! Standing on that bare mountain-top, we 
think of the ages represented by the quartzite of those craggy precipices below, then of the time when the region lay beneath the waters in which the coal jungles spread over a large part of Ireland. We try to realise how these jungles sank foot by foot beneath the sea, how sand and silt were heaped over them, and how, in course of ages, this submerged area was once more upraised into land. But we fail to form any adequate conception of the lapse of time required for the long succession of changes that followed. We only know that, slowly and insensibly, by the fall of rain, the beating of wind, the creeping of ice-fields, and the surging of the ocean, hollow and glen have been carved out, hill after hill has emerged, like forms from a block of marble under the hand of a sculptor, that ravines have been cut out here and crags have been left there, until, at last, the whole landscape has been wrought into its present forms.

We look once more down the face of the precipice, now lit up by the advancing sun, and, though everywhere upon its ruined surface we mark how-

'Nature softening and concealing, Is busy with a hand of healing'-

crusting the bare rock with golden lichen, or hiding its rawness under a cover of richly tinted weather-stains, we none the less perceive the sure signs of constant and inevitable decay; we recognise the working of the same forces that have sculptured the whole landscape, far as well as near; and we feel awed in presence of this revelation of the continuity of law and of the potency even of the unregarded operations of nature when they 


\section{LANDSCAPE AND IMAGINATION}

have had untold ages in which to accomplish their appointed work.

I should like now to transport the reader to a wholly different scene, that we may consider together some of the more obvious features in the landscapes of the south coast of England. At the western end of the Isle of Wight, a long ridge of chalk-down, which stretches completely across the island, runs out to sea, and terminates in the well-known white pinnacles of the Needles. From the highest part of the ridge, when the air is clear, the eye ranges southward over a vast expanse of open sea. To the west and north the breadth of water is bounded by the blue hills of Dorsetshire, the white cliffs of Swanage Bay, and then the long low brown heights which are crowned with the spires of Bournemouth and Christchurch. Eastward we note how the ridge on which we stand sinks down into the hollow of Freshwater Gap, but rises again on the farther side, and then striking inland for some miles, sweeps round to form the heights of St. Catharine's, nearly 800 feet high, whence it descends once more in white cliffs to the sea.

On a summer noon, when a fresh westerly breeze roughens the sea into deepest azure, and keeps a continual murmur of plashing waves at the foot of the cliffs, few pieces of English coast scenery offer more attractions than this. From the verge of the short green sward of the down, the chalk plunges in a sheer precipice of dazzling whiteness, that contrasts well with the mingled blue and emerald-green of the sea below. Projecting massive buttresses, that catch the full blaze of sunlight, throw into delicate violet shadow the 
recesses and alcoves into which the face of chalk has been worn. On the great ocean highway in front, vessels of every size and rig sail past on their outward or homeward voyage. Though our perch above the precipice is solitary, we yet feel within sight and touch of the living world. Across the bay we mark the smoke of distant villages and towns, and the fields and woodlands that separate the scattered hamlets. Just below, at the northern foot of the ridge, sheltered and concealed among its woods, lies that home so dear to lovers of English literature, where-

'Groves of pine on either hand, To break the blast of winter, stand, And further on, the hoary channel Tumbles a breaker on chalk and sand.'

Nor are memorials of the past wanting to throw over the scene the priceless charm of old memory and tradition. The down is roughened here and there with 'the grassy barrows of the happier dead.' The steeples and towers of the country churches dotted over the landscape, mark still, as they have done for centuries, the heart of each parish and its quiet graveyard. It is a typically English scene, full of that hallowed, historic interest, and of that subdued, unobtrusive beauty, where the lineaments of nature are everywhere more or less concealed by the labours of man, which constitute so chief a source of pleasure in the landscapes of England.

Here, surely, our literary censor may claim that no room can be found for the foot of science. What can we pretend to add to the charm of such scenery; or what can we do, if we touch it at all, but lessen 


\section{LANDSCAPE AND IMAGINATION}

that charm? Again, I accept the challenge, though with perhaps somewhat more diffidence; not that I think the contribution from science is here less available or less appropriate, but because I so fully share in the feeling that a scene, in itself and to the ordinary eye so full of everything that can give pleasure, needs no addition from any source.

Let me suppose that we are placed upon the extreme western verge of the down, with the Needles in front of us. The chalk that forms these white faces of rock is shown by science to be made up entirely of the mouldered remains of creatures that gathered on the sea-bottom, ages before the species of animals living at the present day came into existence. Sponges, crinoids, corals, shells, fishes, reptiles, mingled their remains with those of the minuter forms of life that accumulated on the floor of that ancient ocean. And now, hardened into stone, the ooze of that sea-bed has been upraised into land. The 'long backs of the bushless downs,' which for many successive centuries have remained as we see them, were originally parts of the sea-bed, and are entirely built up of the vestiges of dead organisms.

But this is not all. Look at one of those noble faces of rock which shoot up from the restless breakers, and take note of the parallel lines of dark flints which, as if traced with a pencil, sweep in such graceful curves from base to crest of the cliffs. Alike on buttress and recess, from headland to headland, no matter how irregularly the chalk has been sculptured, these parallel lines may be followed. A feature so conspicuous in the architecture of the precipices could not escape the 


\section{SCENERY OF ISLE OF WIGH'T 67}

attention of the most casual visitor, but he only vaguely marvels at it, until geology tells him that these dark lines mark successive floors of that ancient sea-floors that gathered one over another, as generation after generation of marine creatures left their crumbling remains upon the bottom. But now they are bent up and placed on end, like books on the shelves of a library. And thus we learn that not only has this ancient sea-bed been turned into dry land, but its layers of hardened ooze have been tilted up vertically, and that it is the worn ends of these upturned layers which form the long ridges of the downs.

But science further makes known to us that beyond the cliffy margin on which we stand, there once stretched an ampler land that has long disappeared. Far over the English Channel the chalk downs once extended with their undulating summits, their smooth grassy slopes, their deep cooms and quiet bournes. That vanished land ran southward, until it ended off in a range of white precipices. The rain that fell on its surface gathered into a river that flowed northward through Freshwater Gap into the Solent. Strange to tell, perched on the top of the present cliffs, to the east of Freshwater, lie fragments of the bed of that ancient stream, consisting of gravel and silt which, as the cliffs are undermined by the waves, tumble to the beach and mingle with the gravel of to-day. In these ancient deposits are found teeth of the long-extinct mammoths which browsed the herbage on slopes that rose southward, where for many a long age the Atlantic has rolled its restless tides and breakers.

Musing on these records of a dim forgotten past, 
we once more turn to the last spurs of chalk and the isolated Needles. There, with eye quickened to recognise what science has to reveal, we trace on every feature of the rocky foreground, inscribed in characters that cannot be mistaken, the story of that process of destruction which has reduced the Isle of Wight to its present diminished proportions. The rains, frosts, and tempests splinter the chalk above and the waves gnaw it away below. Year by year fresh slices are cut off and strewn in fragments over the sea-floor by the unwearying surge. The Needles, once part of the down, are perceptibly less than they were a generation ago. The opposite white cliffs and downs of Dorset were at one time continuous with those of the Isle of Wight. They too, by their shattered precipices, tunnelled caverns, and isolated stacks of rock, tell the same tale of disintegration. And, thus, impressive though the scenery was before, it now acquires a new interest and significance, when every cliff and pinnacle becomes eloquent to us of a past so strange, so remote, and yet so closely linked with our own day by a chain of slow and unbroken causation.

And now, as a last illustration, let me conduct the reader in imagination to the far north-west of Scotland and place him on the craggy slopes above the upper end of Loch Maree as the sun, after a day of autumnal storm, is descending towards the distant Hebrides in a glory of crimson, green, and gold. Hardly anywhere within the compass of our islands can a landscape be beheld so varied in form and colour, so abounding in all that is noblest and fairest in our mountain scenery. To the right rises the huge mass of Slioch, 


\section{A HIGHLAND SCENE}

catching on his terraced shoulders the full glow of sunset, and wreathing his summit with folds of delicate rose-coloured cloud. To the left, above the purple shadows that are now gathering round their base, tower the white crags and crests of Ben Eay, rising clear and sharp against the western sky. Down the centre, between these two giant buttresses, lies Loch Mareethe noblest sheet of water in the Scottish Highlands -now ablaze with the light of the sinking sun. Headland behind headland, and islet after islet rise as bars of deep violet out of that sea of gold. Yonder a group of pines, relics of the old Caledonian forest, stand boldly above the rocky knolls. Around us the naked rock undulates in endless bosses, dotted with boulders or half-buried in the deep heather that flames out with yet richer crimson in the ruddy light filling all the valley. Overhead, the banded cliffs of Craig Roy, draped with waterfalls and wet with the rains of the earlier part of the day, glow in the varying tints of sunset. We hear the scream of the eagles that still nest in these inaccessible crags; the hoarse outcry of the heron comes up from the lake; the whirr of the blackcock re-echoes down the hill-side. It might seem as if we were here out of sight and hearing of man, save that now and then the low of cattle, driven home to their stalls, falls faintly on the ear from the distant hamlet, which is fading into the gathering twilight of the glen.

At such a time and in such a scene the past speaks vividly to us, if there be human associations of a bygone time linked with the place. Here, in this remote Highland valley, we are led backward in im- 


\section{LANDSCAPE AND IMAGINATION}

agination through generations of strife and rapine, clan warfare and private revenge, bravery and treachery, superstition and ignorance, far away to that early time when, in the seventh century, Maelrubha, the red priest from Ireland, preached to the savage Picts, and first brought this region within the ken of civilised men. More than twelve hundred years have since passed away, but the memory of that early missionary still lives here among the solitudes which he chose as the scene of his labours. The lake yet bears his name, and his favourite island of retirement, embowered in holly, mountain ash, and honeysuckle, contains his holy well, which, even to this day, is visited for the cure of diseases, while offerings are there made to the saint.

It is just this little touch of 'the still, sad music of humanity' which is needed to crown the interest and dignity of our Highland landscape. "What more, then, can we need or desire?' our literary critic may once more demand; "you may go on to elaborate the details of the scene, for every part of the picture abounds in the most exquisite detail, beyond the power of pen or almost of pencil adequately to pourtray. But what can science do here, except to mar what already is perfect, or to confuse by contributing what is entirely irrelevant ?'

Again I feel the force of the objection, and all the more because to combat it as I should wish to do, would involve me in geological details which would here be wholly out of place. Let me say, briefly and decidedly, that after many years of experience in every variety of landscape in this country, 
I know nowhere a scene which has its true inner meaning as a source of impressiveness more strikingly revealed, or which has its ordinary interest more vividly intensified by the light which geological history throws upon it.

The most cursory traveller, even as he drives rapidly along this valley, can hardly fail to observe that three distinct rocks enter into the composition of the landscape, each differing from the others in form, colour, and relative position, and each contributing its own characteristic features to the scenery. First of all a series of curiously hummocky eminences of dark grey rock mounts from the edge of the lake up the sides of Slioch, forming a kind of rude and rugged platform on which that mountain stands. Next comes a pile of brownish red sandstone, which in parallel and almost horizontal bars, like so many courses of cyclopean masonry, forms the upper and main mass of the height. And lastly, there is the bedded white rock which, hanging upon the flanks of the red sandstone, towers in the cliffs of Craig Roy on the one side of the valley and builds up almost the whole of Ben Eay on the other side. The differences and contrasts between these three kinds of material are so marked, and have obviously played so essential a part in producing the special peculiarities of the rocky landscape, that even our literary censor himself could hardly, in spite of himself, fail to note them and might venture to ask a question about them.

To answer his question as it might best be answered would be most briefly and vividly done by a true poet. I can only pretend to present the mere facts, but even 


\section{LANDSCAPE AND IMAGINATION}

such a presentation in the driest and baldest way cannot conceal their inherent marvellous interest.

Those grey bosses of rock that rise out of Loch Maree and form the base and outworks of Slioch are portions of the very oldest known land-surface of Europe, as incalculably more ancient than the rest of the Highlands, as the Highlands in turn are more ancient than the Alps or the Apennines. Their heights and hollows existed before the red sandstones were laid down. To this day, you can walk along the shore-line of the vanished lake or sea in which these sandstones accumulated, and can mark how hill after hill, and valley after valley, sank under its waiers, and were buried beneath its quietly gathering sand and shingle. That primeval land-surface, slowly settling down, came at last to lie under several thousand feet of such sediment. Long subsequently, after the sand, hardened into sandstone and the gravel, consolidated into conglomerate, had been partially raised out of water, came the time when the white rock of Ben Eay and Craig Roy gathered as fine white sand on the sea-bottom. Some beds of this compacted sand are filled with millions of the burrows of sea-worms that lived in it, and higher up come bands of shale and limestone containing here and there trilobites, shells, corals, sponges and other organisms belonging to an age anterior to that of even the very oldest fossiliferous rocks of most of the rest of Britain. These sheets of marine sediment point to a period when there were no hills in north-west Scotland, for the primeval heights still lay deeply buried, and a shoreless sea spread far and wide over the region. 


\section{HISTORY OF LOCH MAREE}

At length after a vast interval of time came an epoch of gigantic terrestial disturbance, when north-western Europe, from the North Cape to the south of Ireland, was convulsed; when the solid crust of the earth was folded, crumpled, and fractured, until its shattered rocks, crushed and kneaded together, acquired the crystalline characters which they now display. In the course of these tremendous displacements (to which there is no parallel in the later geological history of this country) huge slices of the earth's crust, many hundreds of feet thick and many miles long, were wrenched asunder and pushed bodily westwards, sometimes for a distance of ten miles. By this means portions of the oldest rocks of the region were torn off and planted on the top of the youngest. The whole country, thus broken up, underwent many subsequent mutations, and was finally left to be gradually worn down by the various agents that have carved the surface of the land into its present shape.

Our three groups of rock, so distinctly marked out in the landscape, thus record three successive and early chapters in the long history by which the topography of the Scottish Highlands has been brought into its existing form. Knowing what is their story, we find that every crag and scar acquires a new meaning and interest. Past and present are once more brought into such close and vivid union that while we gaze at the landscape as it stands now, its features seem to melt away into visions of what it has once been. We can in imagination clothe it with its ancient pine-forests through which the early Celtic colonists hunted the urus, the wild boar, the wolf, the brown bear, and the 


\section{LANDSCAPE AND IMAGINATION}

reindeer. We can fill up the valley with the stately glacier which once stretched along its hollow and went out to sea. We can dimly conceive the passage of the long ages of persistent decay by which mountain and glen, corry and cliff were carved into the forms which now so delight our eye.

In a memorable and often-quoted passage, Johnson wrote, 'To abstract the mind from all local emotion would be impossible, if it were endeavoured, and would be foolish if it were possible. Whatever withdraws us from the power of our senses, whatever makes the past, the distant, or the future predominate over the present, advances us in the dignity of thinking beings.' ${ }^{1}$ If this be a just judgment, surely we may further maintain that whatever heightens our interest in the landscapes around us, whatever quickens the imagination by presenting new views of what has long been familiar, whatever deepens our reverence by teaching us to recognise the proofs of that long orderly progress through which the land has been fashioned for our use, undoubtedly raises us in the dignity of thinking beings, stimulates the emotional side of our nature, and furnishes abundant material for the exercise of the literary and artistic faculties. Science even in her noblest inspirations, is never poetry, but she offers thoughts of man and nature which the poet, in the alembic of his genius, may transmute into purest poetic gold.

But we have lingered by the side of this northern lake, with its noble curtain of mountains, and the sun meanwhile has sunk in a glory of flame beneath the

${ }^{1}$ Tour in the Hebrides, P. 346. 


\section{LOCH MAREE}

faint outline of the Hebrides ; the last flush of crimson has faded from the sky and the twilight is deepening into night adown the valley. In leaving the scene, if I have succeeded in showing how we have it in our own power to quicken the influence of scenery on the imagination, we may I trust take with us the full conviction that there is no landscape so fair which may not be endued with fresh interest if the light of scientific discovery be allowed to fall upon it. Bearing this light with us in our wanderings, whether at home or abroad, we are gifted, as it were, with an added sense and an increased power of gathering some of the purest enjoyment which the face of Nature can yield. 


\section{III}

\section{Landscape and Literature ${ }^{1}$}

THE several races of mankind are marked off from each other by certain bodily and mental differences which, there can be no doubt, have been largely determined by the diverse geographical conditions of the surface of the globe. We may be disposed to put aside the first origin of these racial differences, as a problem which may for ever remain insoluble. Yet we cannot refuse to admit that in the disposition of land and sea, in the form and trend of coast-lines, in the grouping of mountains, valleys, and plains, in the disposition and flow of rivers, in the arrangement of climates, and in the distribution of vegetation and animals, a series of influences must be recognized which have unquestionably played a large part in the successive stages of human development.

Though no record of the earliest of these stages has probably survived, some of the later steps in the progress of advancement may not be beyond the reach of investigation. The connection, for example,

${ }^{1}$ Types of Scenery and Their Infuence on Literature, the Romanes Lecture, delivered in the Sheldonian Theatre, Oxford, June I, 1898 . 


\section{EARLY INFLUENCE OF SCENERY 77}

between the circumscribing topography and geology of a country, and the mythological creed of its inhabitants offers a tempting field of inquiry, in which much may yet be gleaned. Who can doubt that the legends and superstitions of ancient Greece took their form and colour in no small measure from the mingled climates, varied scenery, and rocky structure of that mountainous land, or that the grim titanic mythology of Scandinavia bears witness to its birth in a region of rugged snowy uplands, under gloomy and tempestuous skies ? 1

If the primeval efforts of the human imagination were thus stimulated by the more impressive features of the outer world, it is natural to believe that the same external influences would continue to exert their power during the later mental development of a people. In particular, it seems reasonable to anticipate that such potent causes would more or less make themselves felt in the growth of a national literature. The songs and ballads of the plains might be expected to present some marked diversities from those of the mountains. There may, of course, be risks of error in generalisations of this kind, especially where the writings of distinct races are compared with each other. But the risks may be reduced if we confine ourselves to the consideration of a single country and a single literature. Such at least is the task which I have undertaken on the present occasion. I propose to discuss the leading types of scenery that distinguish the British Isles, and to inquire how far it may be

${ }^{1}$ See the preceding essay for a fuller discussion of this part of the subject. 
possible to trace from each of them an influence upon the growth of English literature as shown in our poetry.

Under the term scenery may be included those variations in the general aspect of the land that arise from the combined effects of three main geographical elements-topography, climate, and vegetation. Of these three factors, we are mainly concerned with the first, but the other two will necessarily obtrude themselves continually on our attention.

Although geological details are not essential for the inquiry before us, nevertheless some knowledge of them will be found of service in enabling us to recognise more clearly the essential features of a landscape, and to discriminate the real nature and extent of the diversities between the landscapes of different parts of the country. The fundamental elements of the scenery depend upon the nature and structure of the rocks that come to the surface, and the manifold varieties of external form arise from the constant succession of different geological formations.

The evolution of the scenery of these islands has been a long-continued process, wherein the chief part has been played by the air, rain, rivers, frost, and the other superficial agencies which are continually at work in wearing down the surface of the land. Each different kind of rock has yielded in its own fashion to the agents of destruction. Those rocks which have offered least resistance have been worn down into hollows and plains. Those of a more durable nature have been left standing up as ridges, hills, or mountains. The composition of the rocks has likewise 


\section{TYPES OF BRITISH SCENERY}

governed the nature of the soils and the distribution of vegetation. Chalk, for instance, forms long ridges of grassy and bushless down. Sandy and gravelly tracts are marked by heather and pine-trees. Volcanic rocks often rise into isolated crags with verdant slopes below. Granite lifts itself into mountains and rocky moorlands, with cliffs, corries and 'tors' and long trails of naked scree.

For the purposes of the present Lecture, I will arrange the scenery of this country in three leading types :

\section{Lowlands. \\ II. UPLANDS. \\ III. Highlands.}

These types are not always separable from each other by any definite lines of boundary. The lowlands, for example, include ranges of hills, and here and there gradually rise into uplands, which in turn occasionally mount into lofty, rugged ground that may well be called highland. Moreover, each type presents a number of local varieties, dependent on geological structure. Thus the English lowlands differ in many respects from the Scottish, and both from the Irish.

The arrangement now proposed, though not strictly scientific, is for the proposed discussion convenient. We shall find, I think, that each of the three main types has had a perceptible influence on our literature, and not only so, but that even the local variations of each type have left their impress on our literary history. To treat the subject as fully as it deserves 
to be treated would require a course of lectures. I can only attempt to illustrate it by selecting a few instances from our poets where the relation that I wish to establish seems to be most readily perceptible.

I. The Lowlands of Britain. If a line be drawn across England from the mouth of the Humber through the Midlands to the Bristol Channel, it will divide the country into two sharply contrasted portions. To the west of it, the older, harder, and therefore more durable rocks rise into the high grounds of Wales, the Pennine Chain, and the Lakes. To the east of it, on the other hand, the younger, softer, and consequently more destructible, formations occupy the whole of the territory, giving a characteristic lowland topography to the districts that have been longest settled and cultivated, which include the greater portion of what is most familiar and typical in English landscape.

The eastern Lowlands of England consist of a succession of gently undulating ridges, separated from each other by winding vales or plains. These features have a general trend across the country from south-west or west to north-east or east-a direction determined by the successive outcrops of the different formations. But the denudation of the surface has been so great and so unequal that, despite the continuity and parallelism of the formations, their outcrops have been worn into endless diversities of topographical detail, producing abundant variety among the gentle profiles of the landscapes.

As examples of the ridges, we may take the North and South Downs, and the chain of heights that stretches 
from Wiltshire into Norfolk. The intervening plains may be illustrated by the Weald of Sussex, and by the lower basin of the Thames.

The differences between the successive geological formations of the English lowlands never pass a restricted limit in regard to composition and structure. Essentially soft and easily decomposable, the rocks include no thick bands of much harder material than the rest, such as might project in prominent features. The prevailing characteristic of the topography is therefore unbroken placidity. Nowhere does any ruggedness obtrude itself. No part of the ground towers abruptly above or sinks suddenly beneath the general level. The successive ranges of low hills have rounded summits and smooth slopes, which, even when steep, seldom allow naked rock to appear, but conceal it everywhere under a carpet of herbage. So gentle is the inclination of the ground, from the watersheds to the coast, that the drainage winds in sluggish streams that often hardly seem to flow. 'Purling brooks' are scarcely ever to be found. Since the running waters of the country have played no inconsiderable part in the inspiration of our poets, it is well worthy of remark that in the east and south-east of England the streams are, for the most part, silent. We shall see how strongly they are thus contrasted with the brooks that traverse the lowlands of the north.

Since the rocks of these eastern and southern districts decay into soils that are on the whole fertile, the surface, well watered by the rains from the western ocean, is clothed with meadows, corn-fields, and gardens, while trees have been planted along the roads 


\section{LANDSCAPE AND LI'TERA'TURE}

and fields, and in abundant patches of coppice and woodland. The country thus wears a verdant parklike aspect, which at once impresses the eye of a stranger who comes here either from the European continent or from America. Undoubtedly cultivation has in the course of long centuries considerably altered the primeval landscapes; the progress of agriculture having gradually narrowed the area of the once predominant open heaths, while the ancient forests, formerly so abundant and extensive, have wellnigh vanished. There can be little doubt, however, that the general enclosed and cultivated character of the landscapes has, over much of the ground, remained nearly the same as now for hundreds of years.

One further feature of these English lowlands should be borne in mind. They are washed by the sea along the whole of their eastern and southern borders. Even the most inland part of them is not more than one hundred miles from the coast. Their long lines of ridge and down stretch to the very margin of the land, where they plunge in picturesque cliffs to the sea-level, as in the headlands of Flamborough, Dover, and Beachy. Moreover the coast-line is indented by numerous bays, creeks, and inlets, which, as they allow the sea to penetrate far into the land, furnish many admirable natural harbours. There can be no doubt that this feature in our topography has powerfully fostered that love of the sea which has always been a national characteristic, and has contributed to the development of that maritime power which has led to the establishment of our world-wide empire. ${ }^{1}$ 
To the same cause may be traced that appreciation of the poetry of the sea so noticeable in our literature.

We may now inquire how far the placid scenery of these eastern lowlands may have had an influence on the literary progress of the nation. It is of course chiefly among the poets that traces of such an influence may be expected to be discoverable. Not until comparatively late times did prose-writers deal with scenery, save as a mere background for the human incidents which they had to describe. It is impossible, within the prescribed limits of a single lecture, to follow the gradual development of an appreciation of landscape among the writers who have lived on these English lowlands. The simple childlike delight in Nature, so characteristic of Chaucer, and the influence of cultivated scenery, so conspicuous in him, are readily traceable among his successors. Shakespeare throughout his plays presents us with not a few reminiscences of his youth among the Warwickshire woodlands. In Milton we see how the placid rural quiet of the Colne valley inspired the two finest lyrics in the English tongue. For a century after Milton's time, poetry in this country ceased to have any living hold on outer nature, but became with each generation more polished and artificial. When at last a reaction set in, the impulse that led to the most momentous revolution that has marked the history of English poetry came in large measure from the writings of three poets, each of whom drew his inspiration from lowland scenery. As illustrations therefore of the part played by this 


\section{LANDSCAPE AND LITERA'TURE}

scenery in our literature, I will cite Cowper, Thomson, and Burns.

The retreat in the valley of the Ouse, to which Cowper escaped from the noise and distractions of citylife, was eminently fitted by its quiet seclusion to soothe his spirit, and to fill his eye and his imagination with images of rural peacefulness and gentle beauty. If the choice of such a home was of infinite service to the poet, it was hardly less momentous in the progress of English literature.

The scenery of that valley, around Olney and Weston, is thoroughly characteristic of the southern lowlands. The ground lies on limestones and clays, belonging to the Oolitic series, which, though they have been greatly denuded, have yielded in a general equable manner to the progress of decay. They possess no such differences of structure as to allow one part of them to project in crag or scar above the rest. They have been worn down into a gently undulating plateau or plain, covered with corn-fields and pastures, and dotted with occasional woods and 'spinnies,' or patches of trees. Farms and villages diversify the landscape, while to the north lies the forest-like expanse of Yardley Chase. Through this champaign the River Ouse has cut for itself a winding valley, the bottom of which, quite flat and from a few hundred yards to upwards of a mile in breadth, lies rather more than a hundred feet below the general level of the country. Along the flat alluvial plain, the stream, sluggishly flowing among rushes and sedges, curves in circuitous bends, often dividing so as to enclose insular patches of meadow, which it entirely 
overspreads in times of flood. The slopes rise softly from the river-plain, now projecting, now retreating, as the valley winds from side to side. A gentle ascent brings us from the banks of the Ouse up to the highest part of the ground in the vicinity, and places before our eyes a wide sweep of rich agricultural country, with peeps of village spires and gleams of the winding river.

Such were the simple elements of Cowper's landscape. They have no special attraction that is not shared by hundreds of other similar scenes in the Oolitic tracts of England. To the cursory visitor they may even seem tame and commonplace. And yet for us, apart from any mere beauty they may possess, they have been for ever glorified and consecrated by the imagination of the poet. We see in them the natural features which soothed his sorrow and gladdened his heart, and which became the sources of an inspiration that breathed fresh life into the poetry of England. The lapse of time has left the scene essentially unchanged. We may take the same walks that Cowper loved, and see the same prospects that charmed his eyes and filled his verse. In so following his steps, we note the accuracy and felicity of his descriptions, and appreciate more vividly the poetic genius which, out of such simple materials, could work such a permanent change in the attitude of his countrymen towards nature. As an illustration of his treatment of landscape let me cite the well-known passage descriptive of the walk between Olney and Weston-

' How oft upon yon eminence our pace Has slackened to a pause, and we have borne 


\section{LANDSCAPE AND LITERATURE}

The ruffing wind, scarce conscious that it blew, While admiration, feeding at the eye, And still unsated, dwelt upon the scene. Thence with what pleasure have we just discerned The distant plough slow-moving, and beside His labouring team, that swerved not from the track, The sturdy swain diminished to a boy!

Here Ouse, slow-winding through a level plain

Of spacious meads with cattle sprinkled o'er, Conducts the eye along his sinuous course Delighted. There, fast rooted in their bank, Stand, never overlooked, our favourite elms, That screen the huntsman's solitary hut; While far beyond, and overthwart the stream, That, as with molten glass, inlays the vale, The sloping land recedes into the clouds; Displaying, on its varied side, the grace Of hedge-row beauties numberless, square tower, Tall spire, from which the sound of cheerful bells Just undulates upon the listening ear, Groves, heaths, and smoking villages remote.' ${ }^{1}$

No scene could have been more thoroughly congenial to such a temperament as that of Cowper. $\mathrm{He}$ never wearied of the sights and sounds of that peaceful landscape. He watched its changes from hour to hour, from day to day, and from season to season. Every change awakened new joy in his breast, and gave fresh inspiration to his verse. And so year after year he lived in closest communion with nature. Well might he say that

'Scenes must be beautiful which, daily viewed

Please daily, and whose novelty survives

Long knowledge and the scrutiny of years.' 2
${ }^{1}$ The Task, bk. i. 154-176.
${ }^{2}$ Ibid., i. 177 . 
Cowper's poetic vision was like his landscape, limited, though within its range it was searching and accurate. His timid nature shrank from what was rugged and wild. He found his consolation in

' Nature in her cultivated trim And dressed to his taste.' 1

But no one before him had revealed to men the infinite variety and beauty and charm to be seen by the contemplative eye even in these everyday surroundings. The calm of evening-

'With matron step slow moving, while the Night Treads on her sweeping train,' ${ }^{2}$

or the river shining in the moonlight beneath the 'wearisome but needful length' of Olney bridge, or the creep of autumn over wood and field and weedy fallow, or the advent of winter and the shrouding of the valley under snow, or the coming of spring, when-

'The primrose ere her time

Peeps through the moss that clothes the hawthorn root, ${ }^{3}$

- every mood of nature in this sequestered vale is painted with a vividness and skill that evoke our admiration, and with a sympathy and grace which win our heart. That quiet valley has thus become classic ground, for as long as English poetry is read, the affections of men will be drawn to the home of Cowper by the banks of the Ouse.

The other two lowland writers whom I have selected were contemporaries of Cowper, though Thomson died when Cowper was only seventeen years old. In

${ }^{1}$ The Task, iii. $357 . \quad{ }^{2}$ Ibid., iv. $246 . \quad{ }^{3}$ Ibid., vi. II 2. 


\section{LANDSCAPE AND LITERATURE}

dealing with their influence, we turn to the Scottish lowlands where they both were born, and from which came their poetic impulse.

A traveller, familiar with the low grounds of England, when he first enters the northern lowlands is at once impressed by their much more limited extent. $\mathrm{He}$ finds them to occupy comparatively restricted spaces between uplands and highlands, their largest expanse lying in the broad depression between the southern border of the Highland mountains and the great tract of high pastoral land in the southern counties. Another considerable area of them intervenes between these southern uplands and the flanks of the Cheviot Hills. A further contrast to the English type is to be seen in the broken character of the surface. There are no extensive level flats like those of the English midlands, nor any continuous bands of gentle ridge like those of the English downs. The ground is separated into detached districts by ranges of hills, which sometimes even become sufficiently high and broad to deserve the name of uplands. A third characteristic arises from the great diversity of geological structure, and especially the intercalation of abundant volcanic rocks among the other formations. As a consequence of this intermingling of hard and durable materials with others more easily abraded, the topography is diversified by endless crags and hills rising picturesquely out of the surrounding lower country, and often crowned with ancient castles or ruined peels.

Such a disposition of the elements of the landscape is accompanied with a much greater diversity in the 
mantle of vegetation than is seen among the English lowlands. The surrounding uplands and hills, for the most part bare of trees, are clothed with pasture, save where they support a covering of heathy herbage or dark peat-moss. The lower grounds have in large measure been brought under cultivation, but still retain tracts of moorland, haunted by lapwing and curlew. Though the ancient natural wood has mostly disappeared, hard-wood trees are now abundant, while sombre plantations of fir give a northern character to the landscapes.

But perhaps the feature in these Scottish lowlands which more particularly deserves notice here, is the contrast to be found between their streams and those of south-eastern England. Owing to the uneven forms and steeper slopes of the ground, the drainage runs off rapidly to the sea. The brooks are full of motion, as they tumble over waterfalls, plunge through rocky ravines, and sweep round the boulders that cumber their channels. They furnish, moreover, countless dells and dingles where the native copsewoods find their surest shelter. There the gorse and the sloe come earliest into bloom, and the wild flowers linger longest. There too the birds make their chief home. These strips of wild nature, winding through cultivated field or bare moor, from the hills to the sea, offer in summer scenes of perfect repose. But they furnish too, from time to time, pictures of tumult and uproar, when rain-clouds have burst upon the uplands, and the streams come down in heavy flood, pouring through the glens with a din that can be heard from far.

Brooks and rivers have always had a fascination for 


\section{LANDSCAPE AND LITERATURE}

poets. Their banks supply secluded spots for reverie and communion with nature. Under their shade and shelter, bird and blossom and flower are guarded from the blasts around, while the sparkle and murmur of their waters give a sense of life and companionship even in the depths of solitude. Constant familiarity with such a type of stream as that of the Scottish lowlands can hardly fail to strike the imagination in a different way from that which has attended the slowcreeping and silent brooks of the south-east of England. The Scottish poets, even in the earlier centuries, show traces of the influence of their more rugged surroundings; but not till the eighteenth century did this influence manifest itself in such a manner as to affect the general flow of English literature.

Of the two Scottish lowland poets whom we have now to notice, James Thomson was considerably the earlier. He was born in Roxburghshire in I700, within hearing of the ripple of the Tweed, within sight of the Cheviot and Lammermuir Hills, and in a region famous in Border ballad and song. To the east the uplands of the Cheviot Hills rise as a blue ridge, high enough to come often within the clouds, to catch the first snows of autumn, and to keep them unmelted in northern rifts until the spring. From these long, bare undulating uplands a number of streams descend northwards into the Tweed, each having its own dale, with its own ridge of moors on either hand, and its meadows and cornfields along the bottom. The slope of the ground gives these descending waters such an impetus as sends them dashing over rocky channels, here and there cutting a scaur or 


\section{SCOT'TISH LOWLANDS}

ravine, murmuring over gravelly bottoms, winding through flat haughs, and finally finding their way into the Tweed. The watercourses are thus in themselves full of variety and life, and their charms are enhanced by the alternation of meadow and field, coppice, ferny brake and woodland, through which they wander. Nor are occasional bolder features wanting to enliven these quiet valleys. Here and there knobs of volcanic material rise along the crests of the ridges into prominent hills, which are conspicuous landmarks all over the Border country. Since Thomson's day the plough has no doubt crept further up the hill sides; more wood has been planted and more ground has been enclosed. But there is still plenty of bare moor and peat-moss, and the pastoral character of the district yet remains. The traditions of Border warfare have grown fainter, but the ruined peel-towers still stand as picturesque relics of the old wild times. The climate, too, has not changed. The winter storms still send down the rivers in full flood, and bury the vales in deep snow; the spring whitens the meadows and hedgerows with flower and blossom, and the short summer gives way to an early autumn.

Such was the scenery that inspired the 'sweet poet of the year,' as Burns called him. Thomson came to London in I725, when he was twenty-five years of age, and the following year he published his Winter. The poem, though written at Barnet, took its inspiration from the Border. The verse was turgid, full of latinisms, and sadly lacking in the simplicity and directness which the subject required. Nevertheless these defects could not conceal the genuine 


\section{LANDSCAPE AND LI'TERA'TURE}

poetic gift of the writer, and the poem immediately became popular, for notwithstanding its artificial style, it took the reader at once into the sanctuaries of nature, from which the poetry of the previous hundred years had been exiled. It awakened a general interest in features of landscape never before described so fully or so well in English verse. It painted changes of the sky-tempest, rain-clouds and snow-storms, and it brought the gloom of a northern winter vividly before the imagination of dwellers in a more southerly clime.

Thomson told the world how in his youth,

' Nursed by careless solitude he lived

And sang of nature with unceasing joy,'

and how, with 'nature's volume broad displayed,' it was his sole delight to read therein, happy if it might be his good fortune,

\section{' Catching inspiration thence}

Some easy passage, raptured, to translate.' 2

$\mathrm{He}$ had been used in his early years to muse

'On rocks and hills and towers and wandering streams,' ${ }^{3}$ and these now became the subjects of his song. Thomson, like his greater successor Burns, had from earliest boyhood been familiar with the burns and waters of his northern home. When he came to England he found but little entertainment in the landscapes around London, and longed for 'the living stream, the airy mountain, and the hanging rock.' $\mathrm{He}$ portrays with evident delight the changeful aspect of his native watercourses in the various seasons of
${ }^{1}$ Winter, 8.
2 Summer, 192.
${ }^{3}$ Ibid., 89. 


\section{'THOMSON'S' LANDSCAPE}

the year. $=$ He knew well the 'deep morass' and 'shaking wilderness,' where many of them 'rise high among the hills,' and whence they assumed their 'mossy-tinctured' hue. He traces them as they 'roll o'er their rocky channel' until they at last lose themselves in 'the ample river' Tweed.' He describes them as they appear at sheep-washing time, and dwells on their delights for boys as bathing-places. But it is their wilder moods that live most vividly in his memory, when

'From the hills

O'er rocks and woods, in broad brown cataracts,

A thousand snow-fed torrents shoot at once.' ${ }^{2}$

It is worthy of remark, however, that even though nature is his theme, the poet writes rather as an interested spectator than as an earnest votary. $\mathrm{He}$ reveals no passion for the landscapes he depicts. $\mathrm{He}$ never appears as if himself a portion of the scene, alive with sympathy in all the varying moods of nature. His verse has no flashes of inspiration, such as contact with storm and spate drew from Burns. It was already, however, a great achievement that Thomson broke through the conventionalities of the time, and led his countrymen once more to the green fields, the moors, and the woodlands.

In the successive poems which when placed together made the Seasons, published in I730, Thomson continued to draw on his recollections of the Scottish Border for the descriptions of landscape that form so fundamental a part of his theme. It is interesting to note that even after he had been five years in the south

1 Autumn, 476.

${ }^{2}$ Spring, 381, 400, 402; Summer, I3. 


\section{LANDSCAPE AND LITERA'TURE}

of England, and must have seen in that time much variety of weather and many different watercourses, it is still from the north that he draws his sketches. When, for instance, he tells how in autumn,

'Red from the hills, innumerable streams Tumultuous roar,' 1

the colour of his torrents betrays their Scottish origin. He was thinking of the spates in his native streams which sweep across tracts of Old Red Sandstone, and come down almost brick-red in hue. There are no red rocks, and therefore no red brooks in Middlesex and the surrounding districts.

But before the completion of the Seasons the influence of English lowland scenery had begun to impress itself on Thomson's imagination. The softer and ampler landscape of fruitful plains, with its richer agriculture and fuller population, its farms, villages, and country houses, filled his mind with a new pleasure. Some trace of this widened experience may be seen in the additions successively made to the earlier poems, such as the picture of Hagley Park introduced into the poem on Spring. But it was in his last effusion, The Castle of Indolence, that this English influence gained entire sway, and the Scottish memories faded into the background. Here we find ourselves amid the typical landscapes of the south of England -landscapes, however, so transfused by poetic genius as to acquire an individuality of their own. We are led into 'a lowly dale fast by a river's side'; we wander through 'sleep-soothing groves and quiet lawns 
between'; we see 'glittering streamlets' in a sunny glade'; we skirt a 'sable, silent, solemn forest'; and pass a 'wood of blackening pines,' which runs up the hills on either side, and see the famous castle 'close hid amid embowering trees,' that make a kind of chequered day and night. The landscape, we are told, 'inspires perfect ease'-a quality which must now have become indispensable to the 'bard, more fat than bard beseems.' Thomson, with his adoption of English scenery, had also polished his style and rid himself of much of his turgidity and latinism. $\mathrm{He}$ had changed his theme, too, and had chosen one more in consonance with the prevailing vogue. But to the end he had an eye for the charms of the free open face of nature. For the share he took in bringing back into our literature the recognition of these charms, he will ever hold an honourable place in the history of letters.

It was from another and somewhat dissimilar part of the Scottish lowlands that a far more powerful impulse than that of Thomson was given by the genius of Burns to the progress of the literary revolution of the eighteenth century. The landscapes of Ayrshire, where Burns was born and spent most of his life, though akin in their main aspects to those of Roxburghshire, present nevertheless certain wellmarked differences in topography which were not without their influence on the muse that inspired Tam o' Shanter and Halloween.

The lowlands familiar to Burns throughout most of his life form a wide and undulating plain, surrounded on three sides by ranges of upland, and on the fourth by the open Firth of Clyde. The heights along the 


\section{LANDSCAPE AND LITERA'TURE}

southern side belong to the long and broad chain of uplands which stretches from Portpatrick to Saint Abb's Head. Rising sometimes to more than 2,500 feet above the sea, they stretch as a wide pastoral country, much of which is still covered with ' muirs and mosses many.' These high grounds catch the clouds and mists from the Atlantic, and receive such a copious rainfall as to feed many large streams which cross the lowlands to the sea. The number and size of these streams form a notable feature in the scenery, and the different geological formations through which they flow have contributed to give much variety to their channels. Here they may be seen flowing in a narrow glen, there opening into a wider strath, or creeping sullenly in a narrow chasm between precipitous walls of naked stone, or dashing merrily over rock and boulder beneath overarching trees, or sweeping in wide curves through open meadows or dense woods, and finally carrying their burden of mossy water into the blue firth.

These streams, with their endless changes of aspect, their variations from season to season, their play of sunshine and shadow, their wild flowers and their birds, had a strong hold on the affections of Robert Burns. His best inspiration came to him from them. As he tells us himself :

'The Muse, na Poet ever fand her, Till by himsel he learn'd to wander Adown some trottin' burn's meander, An' no think lang;

O sweet to stray, an' pensive ponder A heart-felt sang.' 1

${ }^{1}$ To William Simpson, stanza 15. 


\section{LANDSCAPE OF BURNS}

In the poem from which these lines are quoted, after alluding to the poetic fame of other streams, while those of his own county remained unsung, the poet declares his resolve to atone for this neglect:

'We'll gar our streams and burnies shine

Up wi' the best.

We'll sing auld Coila's plains an' fells,

Her moors red-brown wi' heather-bells,

Her banks an' braes, her dens an' dells.'

Amply did he fulfil his promise. There is not a river, hardly even a tributary, within his reach, that has not been made famous in his lyrics. In the first bloom of opening manhood it was the Ayr and the Doon that gave him inspiration, and when broken in health and spirits, and with an early grave opening before him, it was by the banks of the Nith that his last poetic impulse arose.

In his relation to Nature there was this great difference between Burns and his literary contemporaries and immediate predecessors, that whereas even the best of them wrote rather as pleased spectators of the country, with all its infinite variety of form and colour, of life and sound, of calm and storm, he sang as one into whose very inmost heart the power of these things had entered. For the first time in English literature the burning ardour of a passionate soul went out in tumultuous joy towards Nature. The hills and woods, the streams and dells were to Burns not merely enjoyable scenes to be visited and described. They became part of his very being. In their changeful aspects he found the counterpart of his own variable moods; they ministered to his joys, 


\section{LANDSCAPE AND LITERA'TURE}

they soothed his sorrows. They yielded him a companionship that never palled, a sympathy that never failed. They kindled his poetic ardour, and became themselves the subjects of his song. He loved them with all the overpowering intensity of his affectionate nature, and his feelings found vent in an exuberance of appreciation which had never before been heard in verse.

Among the natural objects which exerted this potent sway over the poetry of Burns, the streams of Ayrshire and Nithsdale ever held a foremost place. Their banks were his favourite haunt for reverie. They were familiar to him under every change of sky and season, from firth to fell. Each feature in their seaward course was noted by his quick eye, and treasured in his loving memory. Their union of ruggedness and verdure, of sombre woods and open haughs, of dark cliff and bright meadow, of brawling current and stealthy flow, furnished that variety which captivated his fancy, and found such fitting transposition to his verse. His descriptions and allusions, however, are never laboured and prominent; they are dashed off with the careless ease of a master-artist, whose main theme is the portrayal of human feeling. Even when the banks and braes have been the immediate source of his inspiration, Burns quickly passes from them into the world of emotion to which he makes them subservient.

So numerous and descriptive are his allusions to them that a luminous account of the characteristics of the Carrick brooks and rivers might easily be compiled from Burns' poems. At one moment we 


\section{BURNS ON AYRSHIRE STREAMS 99}

find him-appealing to them for sympathy in his grief :

'Ye hazelly shaws and briery dens,

Ye burnies, wimplin' down your glens

Wi' toddlin' din,

Or foaming, strang, wi' hasty stens,

Frae linn to linn.' 1

The same appeal forms the burden of his song on the Banks and braes o' bonnie Doon. He leads us where

'In gowany glens the burnie strays,

Or trots by hazelly shaws and braes,

Wi' hawthorns gray.' 2

He pictures the stream after a rain-storm, when

'Tumbling brown, the burn comes down

And roars frae bank to brae ;' 3

or when the breath of the Atlantic has swept over the wintry hills and the

'Burns wi' snawy wreeths up-choked

Wild-eddying swirl,

Or through the mining outlet bocked

Down-headlong hurl.' 4

But nowhere does his delight in these features of his native landscape find more exuberant expression than in his Halloween, when he interrupts his narrative of Leezie's misadventure to give a graphic picture of one of his brooks in the calm moonlight of an autumn evening.

'Whyles owre a linn the burnie plays,

As thro' the glen it wimpl't;

Whyles round a rocky scaur it strays

Whyles in a wiel it dimpl't;
${ }^{1}$ Elegy on Captain Matthero Henderson.
2 Poem on Pastoral Poetry.
${ }^{3}$ Winter, a Dirge.
${ }^{4} \mathrm{~A}$ Winter Night. 


\section{IOO LANDSCAPE AND LITERATURE}

'Whyles glitter'd to the nightly rays,

Wi' bickerin', dancin' dazzle;

Whyles cookit underneath the braes,

Below the spreading hazel

Unseen that night.'

Born near the river Ayr, and having spent his boyhood and youth in its valley, Burns had ever a special affection for that stream, along whose banks he had composed some of his finest poems. When his enforced emigration to America was settled, and his trunk on its way to the ship, he wrote a parting song in the burden of which the banks of Ayr are made to stand for his native country as a whole :

' The bursting tears my heart declare,

Farewell, the bonnie banks of Ayr.' 1

When the respite came, and he found himself famous and in Edinburgh, the Address which he wrote to the Scottish capital contrasted his reception there with what had gone before, and again his heart was by his beloved river :

'From marking wildly-scattered flowers,

As on the banks of Ayr I stray'd, And singing, lone, the ling'ring hours,

I shelter in thy honour'd shade.'

And lastly, when the shadows were beginning to gather around him at Ellisland, his thoughts would go back to the same scene. In one of his latest and most pathetic songs we find once more a reminiscence of his associations with the river of his youth:

'Ayr gurgling kiss'd his pebbled shore

O'erhung with wild woods, thick'ning green ;

The fragrant birch, and hawthorn hoar,

Twin'd am'rous round the raptur'd scene.

1 The gloomy night is gathering fast. 


\section{BURNS AND HIS LANDSCAPE IOI}

The flowers sprang wanton to be prest, The birds sang love on every spray, Till too, too soon, the glowing west, Proclaim'd the speed of winged day.' 1

When Burns moved from Ayrshire to Nithsdale, he found at his new home another valley and another river that could minister to his inspiration. The Nith took the place of the Ayr. But it could not wholly fill that place, for its landscape is less ample, the hills come closer down upon the valley, while the river, in its lower course, curves from side to side in a wide alluvial plain, without the variety that marks the lower part of the Ayr. We seem to recognise the influence of these differences in the allusions in the songs.

The landscapes of Burns are marked by some curious limitations. Though he was born within sight of the picturesque mountain group of Arran, it does not come within his poetic outlook. ${ }^{2}$ Though the "craggy ocean pyramid' of the Clyde rose so stupendously from the firth in front of him, he makes no use of it further than to tell how 'Meg was deaf as Ailsa Craig.' Its distant grandeur does not seem to have struck his imagination. Indeed, if we examine his treatment of scenery, we may observe that it is the nearer detail that appeals to him. His pictures are exquisite foregrounds with seldom any distinct distance. But perhaps more remarkable still is the small place which the sea takes in the poetry of Burns.

${ }^{1}$ To Mary in Heaven.

${ }^{2}$ This was remarked by Wordsworth in the prefatory note to his lines on Mossgiel. 


\section{IO2 LANDSCAPE AND LI'TERATURE}

We must bear in mind that he was born and spent his boyhood within sight and hearing of the open Firth of Clyde. The dash of the breakers along the sandy beach behind his father's 'clay biggin' must have been one of the most familiar sounds to his young ears. Yet the allusions to the sea in his poems betray little trace of this association. They are in large measure introduced to mark the wide distance between separated friends.

It must be remembered, however, that his life, after he began to write, was passed inland, where the wide firth could only be seen from the rising ground at a distance of several miles. Yet Burns has left testimony that his imagination had not been insensible to the life and movement of the ocean. One of the most effective touches in his picture of the night scene in the Brigs of Ayr is given in the reference to the neighbouring sea-

'The tide-swollen Firth, wi' sullen-sounding roar,

Through the still night dashed hoarse along the shore';

and when his native Muse gives him her benediction she tells how she had watched his passionate love of Nature: 'I saw thee seek the sounding shore,

Delighted with the dashing roar;

Or when the North his fleecy store

Drove thro' the sky;

I saw grim Nature's visage hoar

Strike thy young eye.' ${ }^{1}$

II. The UPLAnds of the British Isles consist of undulating plains or plateaux which lie from 1000 to 
more than 2000 feet above the sea. Seen from a distance, they look like ranges of hill or mountain, but without that variety of peak and crest which a true mountain outline would present. Though they may rise steeply out of the lower grounds, we have only to climb to their summit to find ourselves at the edge of a wide rolling platform, which may stretch for leagues without ever rising into any sharp prominence, or departing from the same monotony of moorland. Yet if we attempt to cross this seemingly continuous tableland, we find our progress barred by many valleys which, deep sunk beneath the general level, divide the plateau into separate blocks or ridges.

The surface of these uplands is for the most part treeless and even bushless. "Where not covered with peat-moss, it is clothed with bent or with heather, kept short and green by periodical burning in the springtime. Herds of cattle and flocks of sheep wander over the pastures, but, save the stone fences, there is little other visible trace of human occupation. It is in the little hollows that lead down into the main valleys, and in these valleys themselves, that trees make their appearance, first in scattered saplings of birch, alder or mountain-ash, and then in thicker copsewoods or in artificial plantations of fir and larch. In these sheltered depressions, the farms and villages of the region have been planted, and cultivation has been slowly pushed upward on the slopes of the fells. Thus the larger part of the area of the uplands is uninhabited, the population being restricted to the more or less sheltered ' hopes,' hollows, dales, and valleys.

This type of scenery presents many local varieties, 


\section{IO4 LANDSCAPE AND LI'TERATURE}

according to the geological structure of the ground. Where the rocks have been but little disturbed, the sides of the valleys display a succession of parallel bars of stone with intervening grassy slopes, such as may be seen among the moors of the East Riding, or in the dales of the Pennine Chain. Where, on the other hand, the rocks have been much compressed and pushed over each other by powerful movements of the terrestrial crust, their erosion has given rise to no regular topography, but they decay into rounded forms covered with heath and herbage, or breaking here and there into rocky scarps, as in Wales and southern Scotland.

Of the British uplands, the only district that claims notice here in connection with our literature is that of the wide Border country of England and Scotland. It stretches through the moorlands of Northumberland and Cumberland into the range of the Cheviots on the one hand, and on the other into the great tract of high ground, which extends through the Lammermuir and other groups of fells from the North Sea to the Solway Firth. For many centuries this region has been preeminently pastoral. The natural forest, which in old times clothed much of its surface, has almost wholly disappeared before modern agriculture, and the plough has in successive generations crept higher up the slopes from the meadows of the dales. But there can be little doubt that though roads and railways have done much to open up these solitudes, the natural features remain essentially unchanged.

It was among these uplands that the Border ballads had their birth. We may therefore pause for a few 


\section{BORDER VALLEYS AND STREAMS IO5}

moments to inquire what trace may still be discernible of the influence of the landscape upon the tales of war and love, of feud and raid and rescue, which have made that Border-land famous in our literature.

At the outset it is desirable to realise the allimportant character of the valleys in the human history of the uplands. From time immemorial, these strips of more sheltered and cultivable ground, lying much below the general level of the moorlands, have been to a large extent cut off from each other by high tracts of fell and peat-moss. Each of them took its name from the stream which, rising far up among the moors, and gathering tributary rivulets from glens on either side, winds down the strip of haugh along the valleybottom. For generations past the people have looked on their native stream with an affectionate regard. ${ }^{1}$ It has been the bond of union that has linked the natives of each dale in one family or brotherhood. The valley itself may vary its scenery as it passes across different parts of the upland, here narrowing into a glen, there widening into a strath; its slopes may change their aspect, now clothed in bent or purple heather, now waving with bracken or birken copsewood, now striped with fields of tillage, but the clear river that dashes merrily onward through these diversities of scene unites them all into one continuous dale.

${ }^{1}$ Scott was familiar with this natural trait. " "That's the Forth," said the Bailie, with an air of reverence, which I have observed the Scotch usually pay to their distinguished rivers. The Clyde, the Tweed, the Forth, the Spey, are usually named by those who dwell on their banks with a sort of respect and pride, and I have known duels occasioned by any word of disparagement.'-Rob Roy, vol. ii., chap. xi. 


\section{IO6 LANDSCAPE AND LI'TERA'TURE}

The isolation imposed on the separate communities by this topography of the ground inured them to habits of self-dependence. It gave them a coherence that served them in good stead for attack or defence in the old days of Border forays. Each stream not only gave its name to the whole valley which it traversed, but to the human population that dwelt by its banks. It was called a 'Water,' such as Leader Water, Allan Water, Jed Water, and many more, and this word 'water' came to be synonymous with the able-bodied inhabitants of the dale. When, for instance, old Buccleuch gave his orders for the ride to rescue Jamie Telfer's cattle, carried off by English thieves, he bade his men

' Gar warn the water, braid and wide, Gar warn it sune and hastilie.'

The marauding propensities of one of these communities would sometimes be condensed into the name of their valley, as where Dick o' the Cow complains that

'Liddesdale's been i' my house last night, And they hae taen my three kye frae me.'

The ballads are so full of human incident as to leave little room even for a background of landscape, but some of the features of the scenery are here and there graphically indicated by a line or even a word. 'The bent sae brown' of the higher ground gives place to ' heathery hill and birken shaw,' with here and there a 'bush of broom' or 'buss o' ling' where the dun deer couches in the glade. We are led to where

'The hills are high on ilka side An' the bought i' the lirk o' the hill.' 


\section{SCENERY OF THE BALLADS 107}

We are màde to see that the 'morning sun is on the dew,' to feel 'the cauler breeze frae off the fells,' and to note here and there 'the gryming of a new-fa'n snaw.' When the king led his army through Caddon ford, in pursuit of the outlaw Murray, and came in sight of Ettrick forest, the ballad tells how

'They saw the darke Forest them before, They thought it awsome for to see.'

But perhaps the natural feature most frequently alluded to in the tales of foray is the flooding of the rivers. In those days bridges were few throughout the Border, and thus a heavy downfall of rain might completely sever all communication between the two sides of a dale. To plunge into these swollen torrents was sometimes the only escape from pursuit, and required fully as much courage and nerve as to stay and face the approaching foe. In the famous ride to Carlisle for the rescue of Kinmont Willie, the party found when they came to the Eden that

'The water was great and meikle of spate.'

But they dashed into it, losing neither man nor horse, but encountering still worse weather on the English side-

'The wind began fu' loud to blaw ;

But 'twas wind and weet and fire and sleet

When they came beneath the castle wa'.'

On their return with their rescued comrade to the river, they saw that it 'flowed frae bank to brim,' but nothing daunted, they plunged into the flood and 


\section{IO8 LANDSCAPE AND LITERA'TURE}

safely swam across. Their pursuers, however, gave up the chase at sight of the rushing torrent:

' All sore astonish'd stood Lord Scroope

$\mathrm{He}$ stood as still as rock of stane; He scarcely dared to trew his eyes,

When through the water they had gane.

" $\mathrm{He}$ is either himsell a devil frae hell,

Or else his mother a witch maun be;

I wadna hae ridden that wan water

For a' the gowd in Christentie.",

But even in the midst of the rough warfare of these olden days, there was often a thread of tender affection and romance woven by the ballad-singers into their tales. The vale of the river Yarrow has been more specially consecrated by these tragic songs, and the 'dowie howms o' Yarrow' have come to be identified with all that is most pathetic in the minstrelsy of the Border. From the time of the early ballads a succession of minor poets had sung of this vale, until the pathos of its history was fully revealed to the whole world by Scott and Wordsworth.

It may be readily granted that the fascination of Yarrow has mainly sprung from the recollection of the human incidents which have been transacted there, and which have been enshrined in so much touching verse. But these tragic associations will not, I think, of themselves wholly account for this fascination, nor for the sad tone of the poetry. There seems to me to be a source of peculiarly impressive power in the scenery of the valley itself, and that to this source not a little of the glamour of Yarrow is to be attributed. Nowhere throughout the whole 
range of the uplands are their characteristic aspects more perfectly displayed. Down the centre of the dale runs the strip of level green haugh, through which the stream meanders from side to side across banks of shingle, with a murmuring cadence that is borne down on the wind like a low plaintive wail. On either hand, the smooth green slopes rise into the rounded summits of the fells, mottled here with sheets of bracken and there with folds of heather. The declivities are indented by little side-valleys, each leading a clear rivulet between grassy banks to the main stream. Nowhere do any rugged features mar the gentle undulations of the ground. The outer world seems to lie far beyond the high hills. that enclose and shelter the quiet valley. There is a deep silence over the scene, broken now and then by the melancholy scream of the curlew or the mournful note of the plover. The mind, amid such surroundings, easily glides from the present into reverie amidst the past. The ruined peel seems to whisper tales of 'old unhappy far-off things and battles long ago.' The greener grass around some mouldering stones points to hamlets long since forsaken and forgotten. The scattered birks and alders recall the 'fair forest' that once clothed the valley with 'many a seemly tree,' and when in these tracts, now sacred only to sheep, there were

' Hart and hynd, and dae and rae, And of a' wild beasts great plentie.'

There is a natural expectation in the mind that scenery which has made for itself so notable a place 


\section{IIO LANDSCAPE AND LI'TERATURE}

in the history of English poetry should present, when first seen, some special charm of attractive beauty. And doubtless many have shared the disappointment so well expressed by Wordsworth and by Washington Irving, who nevertheless had the advantage of being shown over the Border country by its great minstrel himself. But with the instinct of a true poet, Wordsworth soon recovered from his first surprise, and divined the inner spirit of the landscape. Nowhere has that spirit been more felicitously expressed than in his second poem on Yarrow. Contrasting his first anticipation with what he found to be the reality, he addressed the vale:

'Thou, that didst appear so fair

To fond imagination,

Dost rival in the light of day

Her delicate creation:

Meek loveliness is round thee spread,

A softness still and holy;

The grace of forest charms decayed

And pastoral melancholy.'

On the influence of the upland scenery of southern Scotland upon the genius of Scott I must not enter. He spent his boyhood within sight of these hills, he made them his chief home throughout life, and when, shattered in health and fortunes, he returned from Italy, it was among these hills, and in hearing of the murmur of the Tweed, that he wished to die. No one can read the 'Lay of the Last Minstrel,' or 'Marmion,' without coming under the spell of the Border scenery. Among the descriptive sketches of landscape in the Waverley Novels, none are more lovingly and graphically painted than those where Scott 


\section{HIGHLANDS, OF BRI'TAIN}

drew from the vivid recollections of his journeys among the dales and moors of the Southern Uplands.

III. For the purposes of our present inquiry, I would class together as Highlands all the higher, more rugged, and mountainous ground, which differs on the whole from the uplands, not only in its greater elevation, but in the more irregular rocky forms of its surface, the narrower crests of its ridges, and the more peaked shapes of its summits. The geological structure of these tracts of country is generally so complicated that it gives rise to much greater variety of outline than is to be found in either of the other types of scenery. Each kind of rock yields to the weather in its own characteristic way, and as the rainfall is heavier and the slopes are steeper there than elsewhere, the influence of the weather upon the topography is more especially prominent.

In the northern parts of Wales where a group of ancient volcanic rocks has been laid bare by the stupendous denudation of the surface, a small tract of truly highland scenery has been carved out in Cader Idris, Arenig, Snowdon, and the surrounding heights in Caernarvonshire and Merionethshire. Another isolated area of volcanic hills forms the picturesque district of the Lakes. But it is in Scotland that this type is displayed on the largest scale and in the most varied diversity. The Scottish Highlands are built up of the most ancient rocks of the British Islands, and possess a geological structure of extraordinary complexity. They include a vast variety of materials which, rising to the highest elevations in the country, and exposed to 


\section{LANDSCAPE AND LITERA'TURE}

the severest climate, have impressed their individual characters upon the landscapes. Thus, in the northwest, where the simplest grouping of rocks is to be seen, masses of horizontal dark-red sandstone have been carved into the huge pyramids that form so singular a feature in the scenery of Ross and Sutherland (p. 7I). In the central and south-western counties, gleaming white cones show where the quartzites rise to the surface. In the eastern Grampians, high craggy moors, encircled with stupendous corries and precipices, mark the sites of the bosses of granite. Among the Western Isles, dark splintered crests and pinnacles point out the position of the gabbros. Perhaps the most rugged ground is to be seen among the micaschists, which combine a wonderful array of pointed peak and notched ridge, with tumultuous masses of craggy declivity.

In the eastern Grampians, the mountains include broad tracts of undulating moorland, which, though lying along the summits of the chain, are level enough to be capable of conversion into racecourses. These hills are separated from the sea by a tract of lowland, and lie thus entirely inland. On the west side of the Highlands, however, the ground between the straths and glens mounts upward into narrow ridges, not infrequently sharpened into knife-edged crests, while the whole aspect of the landscape is rugged, rocky, and bare. Land and sea appear there to be inextricably intermingled. Islands, peninsulas, and promontories are penetrated or surrounded by sounds and sea-lochs, in such a curious way that even in what might be thought to be the very heart of the country, the tides of 


\section{OSSIAN AND WEST HIGHLANDS II 3}

the Atlantic are found to ebb and flow into remote and solitary glens. The mountains plunge abruptly into the salt water, and for the most part only along the valley-bottoms are little strips of level land to be seen.

As a consequence of this intricate interlacing of land and sea, the warm, damp breezes from the Atlantic furnish abundance of mist, cloud, and rain to the western Highlands. Thus to the wildness of rugged mountains and stormy firths, there is added a marvellous range of atmospheric effect. Nowhere in Britain can such an union be beheld of picturesque mountain-form and of clear and vivid colour. Nowhere is the grandeur of a winter storm more impressive than when a southwesterly gale drives the breakers against the headlands, howls up the glens, and fills every gully with a foaming torrent.

The scenery of the western Highlands of Scotland was first brought prominently before the world by the publication in the year 1760 of what purported to be Fragments of Ancient Poetry, collected in the Highlands. The success of this volume encouraged the translator, James Macpherson, to prepare a much larger collection which he combined into an epic poem and published in 1762, under the name of Fingall. A second epic, Temora, appeared during the following year. Keen discussion arose as to the authenticity of these poems. They were by one group of writers upheld as a priceless contribution to literature, recovered by the skill and labour of one man from the lips of the peasantry, and from faded manuscripts that handed down the traditions of a long vanished past. By another class of disputants they were branded as impudent forgeries 


\section{4 LANDSCAPE AND LITERA'TURE}

palmed off upon the credulity of the world by Macpherson himself.

Into this unhappy and still unsettled controversy I have no intention of entering. For my present purpose it is not necessary to decide whether the so-called poems of Ossian were genuine ancient Celtic productions or were entirely fabricated after the middle of last century, though I think we may safely steer a middle course between the extreme views that have been put forward on either side. Few persons now believe that Macpherson's Epics ever existed as such among the Highlanders. But, on the other hand, it is generally admitted that he really did find a number of Ossianic fragments and that he strung these together no doubt with copious connecting material of his own. How much was genuine and old, and how much spurious and modern, has never yet been satisfactorily determined. But in estimating the influence of Macpherson's Ossian on literature, we have no need to consider the age of the poems. None of these were known to the world at large until I760, and we have therefore only to concern ourselves with their history from that year onwards.

Those who have engaged in the controversy have almost wholly entered it from the literary or antiquarian side. I prefer to approach it from the side of the scenery and topography of the West Highlands, and to inquire how far the Ossianic landscape was a true representation of nature, whether there was anything in it new to our literature, and whether it exerted any lasting effect on the attitude of society towards the type of scenery which it depicted. 
Macpherson had previously published some English verse of little merit and which attracted no notice. But the appearance of his Ossianic translations at once made him famous. The Poems of Ossian not only became popular in this country, but were translated into the more important languages of the Continent.

In studying the landscape of Macpherson's Ossian we soon learn that it belongs unmistakably to Western Argyleshire. Its union of mountain, glen, and sea removes it at once from the interior to the coast. Even if it had been more or less inaccurately drawn, its prominence and consistency all through the poems would have been remarkable in the productions of a lad of four-and-twenty, who had spent his youth in the inland region of Badenoch, where the scenery is of another kind. But when we discover that the endless allusions to topographical features are faithful delineations, which give the very spirit and essence of the scenery, we feel sure that whether they were written in the eighteenth century or in the third, they display a poetic genius of no mean order.

The grandeur and gloom of the Highland mountains, the spectral mists that sweep round the crags, the roar of the torrents, the gleam of sunlight on moor and lake, the wail of the breeze among the cairns of the dead, the unspeakable sadness that seems to brood over the landscape whether the sky be clear or clouded - these features of West Highland scenery were first revealed by Macpherson to the modern world. This revelation quickened the change of feeling, already begun, in regard to the prevailing horror of moun- 


\section{6 LANDSCAPE AND LITERATURE}

tain scenery. It brought before men's eyes some of the fascination of the mountain-world, more especially in regard to the atmospheric effects that play so large a part in its landscape. It showed the titanic forces of storm and tempest in full activity. And yet there ran through all the poems a vein of infinite melancholy. The pathos of life manifested itself everywhere, now in the tenderness of unavailing devotion, now in the courage of hopeless despair.

Ossian fascinated some of the greatest men of the time. These Celtic poems, in the words of Matthew Arnold, passed 'like a flood of lava through Europe.' In the deliberate judgement of this acute critic, they revealed 'the very soul of the Celtic genius, and have the proud distinction of having brought this soul of the Celtic genius into contact with the genius of the nations of modern Europe, and enriched all our poetry by it.' 1 There can at least be no doubt that they gave a new and powerful impulse to the appreciation of the wilder aspects of nature, and did much to prepare the way for that love of mountain-scenery which has been one of the characteristic developments of the nineteenth century. It is not that in Ossian Highland landscape was deliberately described, but it formed a continually visible and changing background. The prevalent character of the whole range of scenery in the region, and the general impression made by it on the eye and mind, were so vividly conveyed that no one familiar with the country can fail to recognise how faithfully the innermost soul of the West Highlands is rendered.

${ }^{1}$ Arnold, On the Study of Celtic Literature, 1867, p. 152. 


\section{THE OSSIANIC LANDSCAPE}

Never before or since have the endless changes of sky and atmosphere been more powerfully portrayed. In the tempestuous climate of the west of Scotland these changes succeed each other with a rapidity and energy such as the dweller on the southern lowlands can hardly realise. They are faithfully, if somewhat monotonously, reflected in Ossian. All through the poems the air seems ever astir around us. Sometimes it is only a gently-breathing zephyr which

' Chases round and round

The hoary beard of thistle old,

Dark-moving over grassy mounds.' ${ }^{1}$

We mark the graves of dead heroes by

'Their long grass waving in the wind,' and we move onwards 'in the robe of the misty glen' past

'Branches and brown tufts of grass

Which tremble and whistle in the breeze.'

But when the full Atlantic gale sweeps over the land, and the rain-clouds rush in swift procession across the

${ }^{1}$ The quotations here given are from Dr. Clerk's translation of Macpherson's Gaelic version of the Poems. The question has been much disputed whether his English or Gaelic is the original. There can be no doubt that, on the whole, the Gaelic shows greater vividness and accuracy in the description of landscape than the more vague and bombastic English of Macpherson. Dr. Clerk, who has given a literal rendering of the Gaelic line for line, remarks: 'I believe that a careful analysis would resolve very much of Ossian's most weird imagery into idealised representations of the ever-varying and truly wonderful aspects of cloud and mist, of sea and mountain, which may be seen by every observant eye in the Highlands, and it is no fancy to say that the perusal of these poems, as we have them, may be well illustrated by travelling a range of the Highland mountains.'-Poems of Ossian, Dissertation, vol. i. p. lxv. 


\section{8 LANDSCAPE AND LITERATURE}

half-hidden hills, the moaning and shrieking of the storm come like sounds from another world. We seem to hear the tread, and almost to see the forms, of the ghosts of the Ossianic heroes,

'Chasing spectre-boars of mist

On wings of great winds on the cairn.

When bursts the cloud in Cona of the glens,

A thousand spirits wildly shriek

On the waste wind that sweeps around the cairn.'

Nor is the turmoil of the tempest on the sea less vividly depicted. We are shown the

'Waves surging onward in mist,

When their crests are seen in foam

Over smoke and haze widespread.'

In the midst of the gloom we descry a shore-stack against which the ocean

'Dashes the force of billows cold;

White spray is high around its throat,

And cairns resound on the heathery steep.'

With these pictures of tumult on land and sea, there come glimpses of those cherished interludes of bright sunshine, when the western hills and firths are seen at their loveliest. But whether radiant or gloomy the landscape is in unison with the human emotion described-

'Pleasing the tale of the time which has gone;

Soothing as noiseless dew of morning mild,

On the brake and knoll of roes,

When slowly rises the sun

On the silent flank of hoary Bens-

The loch, unruffled, far away,

Calm and blue on the floor of the glens.'

${ }^{1}$ Fingal, iii. 3 . 
As a final sample of the Ossianic landscape, with its kaleidoscopic play of atmospheric effect, answering to the changes of human feeling, let me cite some lines from Fingal:-

'Morna, most lovely among women, Why by thyself in the circle of stones,

In hollow of the rock on the hill alone?

Rivers are sounding around thee;

The aged tree is moaning in the wind;

Turmoil is on yonder loch;

Clouds darken round the tops of Cairns [mountains]; Thyself art like snow on the hill-

Thy waving hair like mist of Cromla,

Curling upward on the Ben,

'Neath gleaming of the sun from the west;

Thy soft bosom like the white rock

On bank of Brano of white streams.'

Though Macpherson roused the interest of the world in the rugged scenery and boisterous climates of the west, it was some time before any other writer followed his lead among the highlands of this country. It is singular to reflect that though the mountain-world, more than any other part of the land, appeals to the imagination, by revealing all that is most impressive in form and colour, and all that is most vigorous in the elemental warfare of nature, it was the last part of the terrestrial surface to meet with due appreciation. Little more than a century has passed since men began to visit the Scottish Highlands for the pleasure of admiring their scenery. Previous to the suppression of the Jacobite rising, that mountainous region was regarded as the abode of a half-savage race, into whose 


\section{I20 LANDSCAPE AND LITERATURE}

wilds few lowlanders would venture without the most urgent reasons. Even after military roads had been made across it, the accommodation for travellers was still generally of the most wretched kind. Those who had occasion to traverse it gave such an account of their experiences as one would hardly now expect to receive from the heart of Africa. ${ }^{1}$ The poet Gray during his visit to Scotland in the year I765, made a brief excursion into the Perthshire Highlands, and, in spite of the discomforts of travel at that time, came away with a vivid impression of the grandeur and beauty of the scenery. But the only record that remains of this impression is to be found in a few sentences in his letters. ${ }^{2}$

${ }^{1}$ In Burt's Letters, which give so graphic a picture of the condition of the Highlands of Scotland between the two risings of 1715 and 1745, the general impression made at that time on the mind of an intelligent stranger by the scenery of the region may be gathered from the following quotations: "I shall soon conclude this description of the outward appearance of the mountains, which I am already tired of, as a disagreeable subject. . . . There is not much variety, but gloomy spaces, different rocks, heath, and high and low, ... the whole of a dismal gloomy brown drawing upon a dirty purple; and most of all disagreeable when the heath is in bloom. But of all the views, I think the most horrid is, to look at the hills from east to west, or vice versa; for then the eye penetrates far among them, and sees more particularly their stupendous bulk, frightful irregularity, and horrid gloom, made yet more sombrous by the shades and faint reflections they communicate one to another.'-Letters from a Gentleman in the North of Scotland to his Friend in London. Fifth edit., vol. i. p. 285.

${ }^{2}$ In writing to Mason he says: 'I am returned from Scotland charmed with my expedition: it is of the Highlands I speak; the Lowlands are worth seeing once, but the mountains are ecstatic, and ought to be visited in pilgrimage once a year. None but those 
Eight years after Gray's visit, Samuel Johnson in I773 made his more adventurous journey to the Hebrides. When we consider what were the discomforts, and sometimes the actual dangers which he had to undergo, we cannot but admire the quiet courage with which he endured them, and the reticence with which he refers to them in his narrative. But Johnson could see no charm in the Highland mountains. In his poem on London he had asked many years before:

'For who would leave, unbrib'd, Hibernia's land, Or change the rocks of Scotland for the Strand?'

Yet when at last he set foot in Scotland, he showed no disposition to prefer its rocks to his haunts in London. Travelling through some of the finest scenery in Western Inverness-shire, this is the language he uses regarding it: 'The hills exhibit very little variety; being almost wholly covered with dark heath, and even that seems to be checked in its growth. What is not heath is nakedness, a little diversified by now and then a stream rushing down the steep. An eye accustomed to flowery pastures and waving harvests is astonished and repelled by this wide extent of hopeless sterility. The appearance is that

monstrous creatures of God know how to join so much beauty with so much horror. A fig for your poets, painters, gardeners, and clergymen, that have not been among them, their imagination can be made up of nothing but bowling-greens, flowering shrubs, horseponds, Fleet ditches, shell-grottoes, and Chinese rails. Then I had so beautiful an autumn; Italy could hardly produce a nobler scene, and this so sweetly contrasted with that perfection of nastiness and total want of accommodation, that Scotland only can supply.'Gray's Works, edit. E. Gosse, vol. iii. p. 223. 


\section{LANDSCAPE AND LITERATURE}

of matter incapable of form or usefulness, dismissed by nature from her care and disinherited of her favours, left in its original elemental state, or quickened only by one sullen power of useless vegetation.' ${ }^{\prime}$

While such was the attitude of the man of letters in this country, influences were at work on the Continent which powerfully affected the relations of literature to the whole realm of outer nature, and more especially to mountain-scenery. Rousseau's descriptions, followed by the more detailed and scientific narrative of De Saussure, drew the attention of society to the fascinations of Switzerland and the Alps. But these influences had hardly had time to exert much sway in their application to the scenery of our own country when the genius of Scott suddenly brought the features of the Scottish Highlands into the most popular literature of his day. In his youth the future poet and novelist had paid some visits to the glens and lakes of Perthshire, where he found many a primitive custom still remaining, which has since vanished before roads, railways, and tourists. In the year 18 ro his Lady of the Lake appeared. Thenceforward the stream of summer visitors set in, which has poured in an ever-increasing flood into the Highlands of Scotland. The general interest thus awakened in the glens and mountains of the north was still further intensified by the advent of the Lord of the Isles, and of Waverley, Rob Roy, and the other novels that depict scenes in the Highlands. Certainly no man ever did so much as Walter Scott to make the natural features of his native country familiar to the whole world.

${ }^{1}$ Journey to the Western Islands of Scotland, 1775, p. 84. 
The literary charm which he threw over the hills and glens of Perthshire kindled a wide-spread enthusiasm for the more rugged aspects of nature, and gave a powerful stimulus to the slowly-growing appreciation of the beauty and grandeur of mountain-scenery.

Nevertheless it must be admitted that Scott's highland landscapes, though more prominent and detailed than those in his descriptions of the lowlands and uplands, were also more laboured and less spontaneous. His pictures are no doubt faithful and graphic, and each of them leaves on the mind a clear impression of the scene depicted. But their effect is produced rather by a multiplicity of touches than by a few masterstrokes of poetic insight and graphic delineation. Moreover they are all in one tone of colour, and lack that changeful diversity so characteristic of mountains. They are chiefly fineweather portraits, as if the poet loved only summer sunshine among the hills, and had either never seen or cared not to portray their gloom, cloud, and storm. We are bound of course to remember that, after all, he was only an occasional visitor to the Highlands. He had not been born among them, and never lived long enough in their solitudes to become intimately versed in all their alternations of mood under changes of sky and season. $\mathrm{He}$ writes of them as an admiring and even enthusiastic spectator, but not as one into whose very soul the power of the mountains had entered. $\mathrm{He}$ never warms among them into that fervent glow of affectionate appreciation which kindles within him in sight of the landscapes of his native Border. 


\section{LANDSCAPE AND LITERATURE}

One other mountainous district in Britain-that of the English Lakes-claims our attention for its influence on the progress of the national literature. Of all the isolated tracts of higher ground in these islands, that of the Lake District is the most eminently highland in character. It is divisible into two entirely distinct portions by a line drawn in a north-easterly direction from Duddon Sands to Shap Fells. South of that line the hills are comparatively low and featureless, though they enclose the largest of the lakes. They are there built up of ancient sedimentary strata, like those that form so much of the similar scenery in the uplands of Wales and the South of Scotland. But to the north of the line, most of the rocks are of a different nature, and have given rise to a totally distinct character of landscape. They consist of various volcanic materials which in early Palaeozoic time were piled up around submarine vents, and accumulated over the sea-floor to a thickness of many thousand feet. They were subsequently buried under the sediments that lie to the south, but, in after ages uplifted into land, their now diversified topography has been carved out of them by the meteoric agents of denudation. Thus pike and fell, crag and scar, mere and dale, owe their several forms to the varied degrees of resistance to the general waste offered by the ancient lavas and ashes. The upheaval of the district seems to have produced a dome-shaped elevation, culminating in a summit that lay somewhere between Helvellyn and Grasmere. At least from that centre the several dales diverge, like the ribs from the top of a halfopened umbrella. 
The mountainous tract of the Lakes, though it measures only some thirty-two miles from west to east by twenty-three from north to south, rises to heights of more than 3,000 feet, and as it springs almost directly from the margin of the Irish Sea, it loses none of the full effect of its elevation. Its fells present a thoroughly highland type of scenery, and have much of the dignity of far loftier mountains. Their sky-line often displays notched crests and rocky peaks, while their craggy sides have been carved into dark cliff-girt recesses, often filled with tarns, and into precipitous scars, which send long trails of purple scree down the grassy slopes.

Moreover, a mild climate and copious rainfall have tempered this natural asperity of surface by spreading over the lower parts of the fells and the bottoms of the dales a greener mantle than is to be seen among the mountains further north. Though the naked rock abundantly shows itself, it has been so widely draped with herbage and woodland as to combine the luxuriance of the lowlands with the near neighbourhood of bare cliff and craggy scar.

Such was the scenery amidst which William Wordsworth was born and spent most of his long life. Thence he drew the inspiration which did so much to quicken the English poetry of the nineteenth century, and which has given to his dales and hills so cherished a place in our literature. The scenes familiar to him from infancy were loved by him to the end with an ardent and grateful affection which he never wearied of publishing to the world. No mountain-landscapes had ever before been drawn so fully, so accurately, and 


\section{I26 LANDSCAPE AND LI'TERATURE}

in such felicitous language. Every lineament of his hills and dales is depicted as luminously and faithfully in his verse as it is reflected on the placid surface of his beloved meres, but suffused by him with an ethereal glow of human sympathy. He drew from his mountain-landscape everything that

'Can give an inward help, can purify

And elevate, and harmonize and soothe.'

It brought to him 'authentic tidings of invisible things '; and filled him with

'The sense

Of majesty and beauty and repose,

A blended holiness of earth and sky.'

For his obligations to that native scenery he found continual expression.

' $Y e$ mountains and ye lakes,

And sounding cataracts, ye mists and winds

That dwell among the hills where I was born,

If in my youth I have been pure in heart,

If, mingling with the world, I am content

With my own modest pleasures, and have lived

With God and Nature communing, removed

From little enmities and low desires-

The gift is yours.'

Not only did his observant eye catch each variety of form, each passing tint of colour on his hills and valleys, he felt, as no poet before his time had done, the might and majesty of the forces by which, in the mountain-world, we are shown how the surface of the world is continually modified.

'To him was given

Full many a glimpse of Nature's processes

Upon the exalted hills.' 
The thought of these glimpses led to one of the noblest outbursts in the whole range of his poetry, where he gives way to the exuberance of his delight in feeling himself, to use Byron's expression, 'a portion of the tempest'-

'To roam at large among unpeopled glens And mountainous retirements, only trod By devious footsteps; regions consecrate To oldest time; and reckless of the storm, . . . . while the mists

Flying, and rainy vapours, call out shapes And phantoms from the crags and solid earth, . . . . and while the streams

Descending from the region of the clouds, And starting from the hollows of the earth, More multitudinous every moment, rend Their way before them-what a joy to roam An equal among mightiest energies!'

In this passage Wordsworth seems to have had what he would have called 'a foretaste, a dim earnest' of that marvellous enlargement of the charm and interest of scenery due to the progress of modern science. When he speaks of ' regions consecrate to oldest time,' he has a vague feeling that somehow his glens and mountains belonged to a hoary antiquity, such as could be claimed by none of the verdant plains around. Had he written half a century later he would have enjoyed a clearer perception of the vastness of that antiquity and of the long succession of events with which it was crowded. ${ }^{1}$

1 Sedgwick did his best to enlighten the poet by his famous Four Letters on the Geology of the Lake District; but these came too late. They were published at Kendal in 1846 , and Wordsworth died in $185^{\circ}$. 


\section{I28 LANDSCAPE AND LITERATURE}

It is curious to remember that three of the poets whom I have singled out as illustrations of the influence of our lowland, upland, and highland scenery upon our literature have held up the geologist to ridicule. Cowper put that votary of science into the pillory among the irreligious crowd, about whose ears the poet loved to 'crack the satiric thong.' ${ }^{1}$ Wordsworth treated the geological enthusiast with withering scorn. $^{2}$ Scott, with characteristic good humour, only poked fun at him. ${ }^{3}$ It was reserved for a poet of our own day to look below the technical jargon of the schools, and to descry something of this wealth

1 Some drill and bore "

The solid earth, and from the strata there

Extract a register, by which we learn,

That $\mathrm{He}$ who made it, and revealed its date

To Moses, was mistaken in its age.

-The Task, bk. iii. I 50.

2 You may trace him oft

By scars which his activity has left

Beside our roads and pathways, though, thank Heaven,

This covert nook reports not of his hand-

$\mathrm{He}$ who with pocket-hammer smites the edge

Of luckless rock or prominent stone, disguised

In weather-stains or crusted o'er by Nature

With her first growths, detaching by the stroke

A chip or splinter-to resolve his doubts:

And, with that ready answer satisfied,

The substance classes by some barbarous name,

And hurries on; or from the fragments picks

His specimen, if but haply interveined

With sparkling mineral, or should crystal cube

Lurk in its cells_-and thinks himself enriched,

Wealthier, and doubtless wiser, than before!

The Excursion, bk. iii.

${ }^{3}$ St. Ronan's Well, chap. ii. The passage is quoted postea p. I66. 
of new interest which the landscape derives from a knowledge of the history of its several parts. But Tennyson only entered a little way into this enlarged conception of nature. There remains a boundless field for some future poetic seer, who letting his vision pierce into the past, will set before the eyes of men the inner meaning of mountain and glen.

And thus, while we recognise the potent influence which the scenery of the country has exerted on the progress of our literature, we can look forward to a fresh extension of this influence as the outcome of geological investigation. Already the result of this widening of the outlook has made itself felt alike in prose and verse. The terrestrial revolutions of which each hill and dale is a witness; the contrasts presented between the present aspect and past history of every crag and peak; the slow, silent sculpturing that has carved out all this marvellous array of mountain-forms -appeal vividly to the imagination, and furnish themes that well deserve poetic treatment. That they will be seized upon by some Wordsworth of the future, I cannot doubt. The bond between landscape and literature will thus be drawn closer than ever. Men will be taught that beneath and behind all the outward beauty of our lowlands, our uplands, and our highlands there lies an inner history which, when revealed, will give to that beauty a fuller significance and an added charm. 


\section{The Origin of the Scenery of the British Islands ${ }^{1}$}

THE insular position of these islands, which we are apt to regard as an essential and aboriginal feature, is merely accidental, and has not always been maintained. The intimate relation of Britain with the Continent is well shown by the Admiralty charts. If the west of Europe were elevated 200 feet-that is, the height of the London Monument-the Straits of Dover, halt of the North Sea, and a large part of the English Channel would be turned into dry land. If the elevation extended to 600 feet-that is, merely the united heights of St. Paul's and the Monument-the whole of the North Sea, the Baltic, and the English Channel would become land. There would likewise be added to the European area a belt of territory from 100 to I 50 miles broad, stretching to the west of Ireland and Scotland.

With an uprise of 600 feet a vast plain would unite

${ }^{1}$ An abstract of five lectures given at the Royal Institution in January, February, and March, I884. Nature, vol. xxix. pp. 325, $347,396,419,442$. The notes here inserted are now added for the first time. 


\section{GEOLOGY OF BRITAIN}

Britain to Denmark, Holland, and Belgium, and would present two platforms, ${ }^{1}$ of which the more southerly would stretch from what are now the Straits of Dover northward to the northern edge of the Dogger Bank, where a steep declivity, doubtless a prolongation of the Jurassic and Cretaceous escarpments of Yorkshire, descends to the northern or lower platform. This submarine escarpment is trenched towards the west by a magnificent valley through which the united waters of the Rhine and Thames would flow, between the Dogger Bank and the Yorkshire cliffs. Another gap further east would allow the combined Elbe and Weser to escape into the northern plain. Possibly all these rivers would unite on that plain, but, in any case, they would fall into a noble fjord which would then be revealed following the trend of the southern coast line of Norway. Altogether an area more than thrice that of Britain would be added to Europe. By a total rise of 1800 feet, Britain would be united to the Faroe Islands and Iceland; while the Arctic and Atlantic Oceans would be separated.

\section{GEOLOGICAL CHARACTERISTICS OF BRITAIN.}

From its position on the oceanic border of a continent, Britain has been exposed to a great variety of geological change. In such a position marine erosion and deposit are most active. A slight upheaval or depression, which would have no sensible effect in the interior of a continent, makes all the difference between land and water on the coast-line. Moreover, there appears to be a tendency to special disturbance along 


\section{I32 ORIGIN OF SCENERY OF BRITAIN}

the edge of an ocean. America affords the most marked proofs of this tendency, but in the structure of Scandinavia and its prolongation into Scotland and Ireland there appear to be traces of similar ancient ridging up of the oceanic border of Europe.

There is a remarkable convergence of geological formations in Britain, each carrying with it its characteristic scenery. The rugged crystalline rocks of Norway reappear in the Scottish Highlands; the fertile chalk, with its smooth downs and gentle escarpment, stretches across to us from the north of France; the great plain of North Germany, strewn with the debris of the northern hills, extends into our eastern lowlands; even the volcanic plateaux of Iceland and Faroe are prolonged into the Inner Hebrides and the north of Ireland.

The present surface of Britain is the result of a long, complicated process in which underground movements, though sometimes potent, have only operated occasionally, while superficial erosion has been continuous, so long as any land has remained above the sea. The order of appearance of the existing features is not necessarily that of the chronological sequence of the rocks. The oldest formations have all been buried under later accumulations, and their re-emergence at the surface has only been brought about after enormous denudation. In its general growth, Britain like the rest of Europe has, on the whole, increased from the north by successive additions along its southern border. Some early upheavals ridged up the Palæozoic rocks into folds running north-north-east and south-southwest, as may yet be seen in Scotland, in the Lake 
Country, and in Wales. By a later series of plications the younger Palæozoic rocks were thrown into noithand-south and east-and-west ridges, the latter of which still powerfully affect the topography ir southern Ireland, and thence through South Wales and Belgium. An east-and-west direction was followed by the more important subsequent European disturbances, such as those that upheaved the Pyrenees, Jura, and Alps. ${ }^{1}$ Some of the latest movements that have powerfully affected the development of our scenery were those that gave the Secondary rocks their general tilt to south-east. It is very doubtful if any part of the existing topography can be satisfactorily traced back beyond Middle or Older Tertiary time. ${ }^{2}$ The amount of erosion of some of the hardest rocks of the country since that date has been prodigious, as may be seen in the fragmentary condition of the volcanic plateaux of the Inner Hebrides.

\section{GENERAL TOPOGRAPHY.}

The main topographical features of Britain may be arranged as mountains, tablelands, valleys, and plains. All our Mountains are the result of erosion on areas of land successively upheaved above the sea. In the development of their forms, the general outlines have

${ }^{1}$ To these east-and-west foldings of the terrestrial crust we owe the plication of our Cretaceous and older Tertiary strata which have given us the ranges of the North and South Downs. They were accompanied by powerful horizontal thrusts of portions of the crust. The successive plications of the terrestrial crust in the European area have since been discussed by Prof. Suess in his Antlitz der Erde.

${ }^{2}$ See note on p. 146. 


\section{I34 ORIGIN OF SCENERY OF BRITAIN}

been mainly determined by erosion, independent of geological structure; while the details have been chiefly guided by structure, but partially also by the rate and kind of erosion. Ruggedness, for example, has resulted primarily trom structure, but has been aggravated by greater activity of erosion. The mountainous west, with a greater rainfall and steeper slopes, is more rugged than the mountainous east.

The Tablelands of Britain are of two orders-I, those of Deposit, which may be either (a) of sedimentary rocks, horizontal or nearly so, as in the Millstone Grit and Jurassic plateaux of Yorkshire, or (b) of volcanic rocks, as in the wide plateaux of Antrim, Mull, and Skye; 2, those of Erosion, where, as the result of long-continued degradation, a series of plicated rocks has been cut down into a more or less uniformly level surface, as in South Wales. By the elevation of such a surface into a high plateau, erosion becomes more active, and the plateau is eventually trenched into a system of ridges and isolated hills, as has happened in the Highlands.

The Valleys of Britain are the result of erosion either (a) guided by geological structure, as in what are called longitudinal valleys, that is, valleys which run along the strike or outcrop of formations, as the Great Glen and Glen Spey in Scotland and the valleys of the Trent and Avon in England; or (b) independent of geological structure, as in the transverse valleys which embrace the great majority of British examples.

Our Plains are due to prolonged erosion, as in the Weald; to the deposit of detritus, as in river-terraces and alluvial plains; to the action of the sea, as 
in raised beaches; and to ice, as in the drift-covered lowlands.

The existing Watershed of Britain is profoundly significant, affording a kind of epitome of the geological revolutions, through which the surface of the country has passed. It lies nearer the west than the east coast. The western slope being thus the steeper, as well as the more rainy, erosion must be greater on that side, and consequently the watershed must be slowly moving eastward. Probably the oldest part of the watershed is to be found in the Highlands, where its trend from north-north-east to south-south-west was determined by the older Palæozoic upheaval. Its continuity has been interrupted by the dislocation of the Great Glen. After quitting the Highlands it wanders across the Scottish Lowlands and Southern Uplands, with no regard to the dominant geological structure of these districts, as if, when its course was originally determined, they had been buried under so vast a mass of superincumbent rock that their structure did not affect the surface. Running down the Pennine Chain, the watershed traverses a region of enormous erosion, yet from its general coincidence with the line of the axis of elevation, we may perhaps infer that the anticline of the Pennine Chain has never been lost under an overlying sheet of later undisturbed rocks. The remarkable change in the character of the watershed south of the Pennine Chain carries us back to the time when the great plain of the Secondary rocks of England was upraised with a gentle inclination to east and south-east. The softer strata between the harder escarpment-forming members of the Jurassic 


\section{I36 ORIGIN OF SCENERY OF BRITAIN}

series and the Palæozoic rocks of the Pennine Chain were worn away, and two rivers carrying off the drainage of the southern end of that chain flowed in opposite directions, the Avon turning south-west and the Trent northwards. By degrees these streams moved away across the broadening plain of softer strata, as the escarpments emerged and retreated. At the same time, streams collected the drainage from the uprising slope of Secondary rocks and flowed south-eastward. Successive lines of escarpment have since been developed, and many minor watersheds have arisen, while the early watershed has undergone much modification, these various changes pointing to the continuous operation of running water.

\section{THE MOUNTAINS AND TABLELANDS.}

A true mountain-chain is the result of plication of the earth's crust, and its external form, in spite of sometimes enormous denudation, bears a relation to the contours produced by the original uplift. Tried by this standard, hardly any of the heights of Britain deserve the name of mountains. With some notable exceptions in the south of Ireland, they are due not to local but to general upheavals, and their outlines have little or no connection with those due to underground movement, but have been carved out of upheaved areas of unknown form by the various forces of erosion. In the course of their denudation, the nature of their component rocks has materially influenced the elaboration of their contours, each well-marked type of rock having its own characteristic variety of mountain forms. 
The relative antiquity of our mountains must be decided not necessarily by the geological age of their component materials, but by the date of their upheaval or of their exposure by denudation. In many cases they can be shown to be the result of more than one uplift. The Malvern Hills, for example, which from their dignity of outline better deserve the name of mountains than many higher eminences, bear internal evidence of having been upheaved during at least four widely separated geological periods, the earliest movement dating from before the time of the Upper Cambrian, the latest coming down to some epoch later probably than the Jurassic period.

The oldest mountain fragments in Britain are those of the Archæan rocks, and of these the largest portions occur in the north-west of Scotland. ${ }^{1}$ Most of our mountains, however, belong to upheavals dating from Palæozoic time, though the actual exposure and shaping of them into their present forms must be referred to a far later period. Two leading epochs of movement in Palæozoic time can be recognised. Of these the older, dating from before the Lower Old Red Sandstone and part at least of the Upper Silurian period, was distinguished by the plication of the rocks in a dominant north-east and south-west direction, and the effects of these movements can be traced in the trend of the Lower Silurian ridges and hollows to the present day.

In Wales two types of mountain-form exist-the Snowdon type, and that of the Breconshire Beacons.

${ }^{1} \mathrm{~A}$ pre-Cambrian group of mountains has been exposed by denudation in the west of Ross-shire. See p. 72. 


\section{I38 ORIGIN OF SCENERY OF BRITAIN}

In the former, the greater prominence of the high grounds arises primarily from the existence of masses of volcanic rocks, which from their superior durability have been better able to withstand the progress of degradation. In the latter the heights are merely the remaining fragments of a once continuous tableland of Old Red Sandstone.

The Lake District presents a remarkable radiation of valleys from a central mass of high ground. It might be supposed that these valleys have been determined by some radiating system of fractures in the rocks; but an examination of the area shows them to be singularly independent of geological structure. So much do they disregard the strike, alternations, and dislocations of the rocks among which they lie that the conclusion is forced upon us that they have been determined by some cause independent of that structure, and before the rocks now visible were exposed at or could affect the surface. This could only have happened by the spread of a deep cover of later rocks over the site of the Lake mountains. The former presence of such a cover, which is demanded for the explanation of the valleys, can be inferred from other evidence. The Carboniferous Limestone on the flanks of the Lake District is so thick that it must have spread nearly or entirely over the site of the mountains. But it was overlain by the Millstone Grit and Coal-measures, so that the whole area was probably buried under several thousand feet of Carboniferous strata which stretched continuously across what is now the north of England. At the time of the formation of the anticlinal fold of the Pennine 
Chain, the site of the Lake District appears to have been upraised as a dome-shaped eminence, the summit of which lay over the tract now occupied by the heights from Scafell to Helvellyn. The earliest rain that fell upon this eminence would gather into divergent streams from the central watershed. In the course of ages, after possibly repeated uplifts, these streams have cut down into the underlying core of old Palæozoic rocks, retaining on the whole their original trend. Meanwhile the whole of the overlying mantle of later formations has been stripped from the dome, and is now found only along the borders of the mountains. The older rocks, partly faulted down and yielding to erosion, each in its own way, have gradually assumed that picturesqueness of detail for which the area is so deservedly famous.

The Scottish Highlands likewise received their initial plications during older Palæozoic time, their component rocks having been thrown into sharp folds trending in a general north-east and south-west direction. ${ }^{1}$ But there is reason to believe that they were subsequently in large measure buried under Old Red Sandstone, and possibly under later accumulations. No positive evidence exists as to the condition of this region during the vast interval between the Old Red Sandstone and the older Secondary rocks. We can hardly believe it to have remained as land during all

1 Since these lectures were given the remarkably complex structure of the North-West Highlands has been made known. It has been ascertained that gigantic horizontal displacements of rock have occurred in that region, and that similar 'thrusts' have more or less affected the rest of the Highlands. 


\section{40 ORIGIN OF SCENERY OF BRITAIN}

that time, otherwise, the denudation, vast as it is, would probably have been still greater. Not improbably the region had become stationary at a base-level of erosion beneath the sea; that is, it lay too low to be effectively abraded by breaker-action, and too high to become the site of any important geological formation. The present ridges and valleys of the Highlands are entirely the work of erosion. When they began to be traced, the area probably presented the aspect of a wide undulating tableland. Since that early time the valleys have sunk deeper and deeper into the framework of the land, the ridges have grown narrower, and the mountains have arisen, not by upheaval from below, but by the carving away of the rest of the block of which they formed a part. In this evolution, geological structure has played an important part in guiding the erosive tools. The composition of the rock-masses has likewise been effective in determining the individuality of the mountain-forms.

The mountains of Ireland are distributed in scattered groups round the great central plain, and belong to at least three geological periods. The oldest groups probably took their rise at the time of the older Palæozoic upheaval, those of the north-west being a continuation of the Scottish Highlands, and those of the south-east being a prolongation of those of Wales. Later in date as regards the underground movements that determined their site, are the mountainous ridges of Kerry and Cork. These are local uplifts which, though on a small scale, are by far the best examples in Britain of true mountain-structure. The Old Red Sandstone and Carboniferous rocks have there been thrown into 
broad arches and troughs which run in a general east and west direction. In some cases, as in the Knockmealdown Mountain, the arch is composed entirely of Old Red Sandstone flanked with Carboniferous strata. But in most instances an underlying core of Silurian rocks has been exposed along the centre of the arch. As not only the Carboniferous Limestone, but the rest of the Carboniferous system covered the south of Ireland and participated in this plication, the amount of denudation from these ridges has been enormous. On the Galty range, for example, it can hardly have been less but may have been more than 12,000 feet. The third and latest group of Irish mountains is that of Mourne and Carlingford, which may with some probability be referred to older Tertiary time when the similar granitic and porphyritic masses in Mull and Skye were erupted.

The Tablelands of Britain strictly include the mountains, which are in general only prominences carved out of tablelands. There are still, indeed, large areas in which the plateau character is well shown. Of these the most extensive and in many respects the most interesting is the present tableland or plain of Central Ireland. As now exposed, this region lies upon an undulating eroded surface of Carboniferous Limestone. But it was formerly covered by at least 3,000 or 4,000 feet more of Carboniferous strata, as can be shown by the fragments that remain. ${ }^{1}$ The present system of drainage across the centre of Ireland took its origin long before the ancient tableland had been reduced

${ }^{1}$ A striking instance of one of these fragments is to be seen on the summit of Slieve League in Donegal. See p. 6I. 


\section{I42 ORIGIN OF SCENERY OF BRI'TAIN}

to its present level, and before some of the ridges, now prominent, had been exposed to the light.

The Moors and Wolds of Yorkshire present us with a fragment of a tableland composed of nearly horizontal Jurassic and Cretaceous rocks. The Lammermuir Hills and Southern Uplands of Scotland extend as a broad tableland which has been formed on a deeply eroded surface of Lower and Upper Silurian rocks.

The Scottish Highlands may also be looked upon as the relics of an ancient tableland cut out of highly crumpled and plicated schists. Among the eastern Grampians large fragments of the plateau exist at heights of more than 3,000 feet, forming wide undulating plains that terminate here and there at the edge of precipices. In the Western Highlands, the erosion having been more profound, the ridges are narrower, the valleys deeper, and isolated peaks more numerous (p. I I 2). It is the fate of a tableland to be eventually cut down by running water into a system of valleys which are widened and deepened, until the blocks of ground between are sharpened into ridges and trenched into separate prominences. The Highlands present us with far advanced stages of this process.

In the youngest of British tablelands-that of the volcanic region of Antrim and the Inner Hebrideswe meet with some of the earlier parts of the change. That interesting tract of our islands reveals a succession of basaltic sheets which appear to have spread over the wide valley between the Outer Hebrides and the mainland, and to have reached southwards beyond Lough Neagh. Its original condition must have resembled that of the lava-fields of Idaho and Oregon-a sea-like 
expanse of black basalt stretching up to the base of the mountains. What may have been the total thickness of basalt cannot be told; but the fragment remaining in Ben More, Mull, is more than 3,000 feet thick. So vast has been the erosion since older Tertiary time that the volcanic plateau has been trenched in every direction by deep glens and arms of the sea, and has been reduced to detached islands. It is strange to reflect that all this revolution in the topography has been effected since the soft clays and sands of the London Basin were deposited.

\section{THE VALLEYS.}

The intimate relation of a system of valleys to a system of drainage lines, first clearly enunciated by Hutton and Playfair, has received ample illustrations from all parts of the world. ${ }^{1}$ But the notion is not yet extinct that, in some way or other, valleys have been as much, if not more, determined by subterranean lines of dislocation than by superficial erosion. Some favourite dogmas die hard, and though this dogma of fracture has been demolished over and over again, it every now and then reappears, dressed up anew as a fresh contribution to scientific progress. We have only to compare the surface of a much dislocated region with its underground structure, where that has been revealed by mining operations, as in our coal fields, to see that valleys comparatively seldom, and then only as it were by accident, run along lines of dislocation, but that they everywhere cut across them, and that faults rarely make a feature at the surface, except in- 


\section{I44 ORIGIN OF SCENERY OF BRI'TAIN}

directly by bringing hard and soft rocks against each other.

In Britain, as in other countries, there is a remarkable absence of coincidence between the main drainage system and the geological structure of the region. We may infer from this fact either that the general surface, before the establishment of the present drainage system, had been reduced to a base-level of denudation above or under the sea, the original inequalities of configuration having been planed off irrespective of structure; or at least, that the present visible rocks were buried under a mass of later unconformable and approximately level strata, on the unequally upraised surface of which the present drainage system began to be traced. Where the existing watershed coincides generally with the crest of an anticline, its position has obviously been fixed by the form of the ground produced by the plication, though occasionally an anticline may have been deeply buried below later rocks, the subsequent folding of which along the same line would renew the watershed along its previous trend. Where drainage lines coincide with structure, they are probably, with few exceptions, of secondary origin; that is, they have been developed during the gradual denudation of the country. Since the existing watershed and main drainage-lines of Britain are so independent of structure, and have been determined chiefly by the configuration of the surface when once more brought up within the influence of erosion, it may be possible to restore in some degree the general distribution of topography when they were begun.

One of the most curious aspects of the denudation 


\section{ASPECTS OF DENUDATION}

of Britain is its extraordinary inequality. In one region the framework of the land has been cut down into the very Archæan core, while in the immediate vicinity there may be many thousands of feet of younger strata which have not been removed. This inequality must result from difference in total amount of upheaval above the base-line of denudation, combined with difference in the length of exposure to denudation. As a rule the highest and oldest tracts will be most deeply eroded. Much of the denudation of Britain appears to have been effected in the interval between the close of the Carboniferous and end of the Triassic period. ${ }^{1}$ This was a remarkable terrestrial interval, during part of which the climate was so arid that salt lakes were formed over the centre of England. Yet the denudation ultimately accomplished was enormous, thousands of feet of Carboniferous rock being entirely removed from certain areas, such as the site of the present Bristol Channel. An interesting analogy to this condition of things is presented by the Great Basin and adjoining tracts of Western America, where at the present time marked aridity and extensive salt-lakes are accompanied by great erosion.

The deeply-eroded post-Carboniferous land of Britain was eventually screened from further degradation, either by being reduced through denudation to a base-level or

${ }^{1}$ Other periods of prolonged denudation might be mentioned. Thus in pre-Cambrian times the Lewisian Gneiss was stupendously eroded before the deposition of the Torridon Sandstone, which in turn was enormously worn down before the Cambrian sediments were spread unconformably over it. The deposition of the Old Red Sandstone was preceded and accompanied by a vast degradation of the pre-existing rocks. 


\section{I46 ORIGIN OF SCENERY OF BRITAIN}

by being protected by submergence. It was to a large extent covered with Secondary rocks, though the covering of these may have been but thin over what are now the higher grounds. The present terrestrial areas emerged at some period later than the Chalk. ${ }^{1}$ In England there were three chief tracts of land-Wales, the Pennine Chain, and the Lake District. The eastern half of the country, covered with Secondary rocks, was probably the last portion to be uplifted above the sea; hence the watersheds and drainage lines in that tract may be regarded as the youngest of all.

The history of some of the valleys of the country tells the story of the denudation. The Thames is one of the youngest rivers, dating from the time when the Tertiary sea-bed was raised into land. Originally its source probably lay to the west of the existing Jurassic escarpment of the Cotswold Hills, and it flowed eastward before the Chalk escarpment had emerged. By degrees the Chalk downs have appeared, and the escarpment has retreated many miles eastward.

${ }^{1}$ That the Secondary formations once extended far beyond the limits within which they are now confined has been impressively demonstrated by the discovery of large masses of Rhaetic, Liassic, and Cretaceous strata in a great volcanic vent of Tertiary age in the Isle of Arran (see Messrs. Peach, Gunn, and Newton, Quart. Journ. Geol. Soc., lvii., 1901). It may consequently be inferred that the present drainage system and topographical features of much, if not most, of the country have been established since the time of the Chalk (see the 'Geology of Eastern Fife' in Memoirs of the Geological Survey, 1902, p. 281). The stupendous erosion of the Tertiary lava-plateaux of the west of Scotland and the north of Ireland shows, in the most impressive way, how greatly the topography has been carved out since older Tertiary time. 
The river, however, having fixed its course in the Chalk, has cut its way down into it, and now seems as if it had broken a path for itself across the escarpment. As all the escarpments are creeping eastward, the length and drainage area of the Thames are necessarily slowly diminishing.

The Severn presents a much more complex course; but its windings across the most varied geological structure are to be explained by its having found a channel on the rising floor of Secondary rocks between the base of the Welsh hills and the nascent Jurassic escarpments. The Wye and Usk afford remarkable examples of the trenching of a tableland. The Tay and Nith are more intricate in their history. The Shannon began to flow over the central Irish plain when it was covered with several thousand feet of strata now removed. In deepening its channel it has cut down into the range of hills north of Limerick, and has actually sawn it into two. ${ }^{1}$

\section{THE LAKES. ${ }^{2}$}

The Lakes of Britain present us with some of the most interesting problems in our topography. It is obvious that the existence of abundant lakes in the more northern and more rocky parts of the country

${ }^{1}$ I have shown that some of the wildest glens of the Highlands and the deepest dales of the southern Uplands of Scotland have been hollowed out since early Tertiary time by the various streams that still flow in them. Scenery of Scotland, 3 rd ed., Pp. 162, 339, 361.

2 The Scottish Lakes have in recent years been made the subject of detailed study by Sir John Murray and Mr. F. Pullar. The results of their investigations have appeared in the Geographical Journal. 


\section{I48 ORIGIN OF SCENERY OF BRI'TAIN}

points to the operation of some cause which, in producing them, acted independently of and even in some measure antagonistically to the present system of superficial erosion. It is likewise evident that as the lakes are everywhere being rapidly filled up by the daily action of wind, vegetation, rain, and streamlets, they must be of geologically recent origin, and that the lake-forming process, whatever it was, must have attained a remarkable maximum of activity at a comparatively recent geological epoch. Hardly any satisfactory trace is to be found of lakes older than the present series. How then have our lakes arisen? Several processes have been concerned in their formation. Some have resulted from the solution of rock-salt or of calcareous rocks and a consequent depression of the surface. The 'meres' of Cheshire, and many tarns or pools in limestone districts, are examples of this mode of origin. Others are a consequence of the irregular deposit of superficial accumulations. Thus, landslips have occasionally intercepted the drainage and formed lakes. Storm-beaches, thrown up by the waves along the sea-margin, have now and then ponded back the waters of an inland valley or recess. The various glacial deposits-boulder-clays, sands, gravels, and moraines-have been thrown down so confusedly on the surface that vast numbers of hollows have thereby been left which, on the exposure of the land to rain, at once became lakes. This has undoubtedly been the origin of a large proportion of the lakes in the lowlands of the north of England, Scotland, and Ireland, though they are rapidly being converted by natural causes into bogs and meadow-land. Un- 
derground movements may have originated certain of our lakes, or at least may have fixed the direction in which they have otherwise been produced. ${ }^{1}$

A large number of British lakes lie in basins of hard rock, and have been formed by the erosion and removal of the solid materials that once filled their sites. The only agent known to us by which such erosion could be effected is land-ice. It is a significant fact that our rock-basin lakes occur in districts which can be demonstrated to have been intensely glaciated. The Ice-Age was a recent geological episode, and this so far confirms the conclusion already enforced, that the cause which produced the lakes must have been in operation recently, and has now ceased. We must bear in mind, however, that it is probably not necessary to suppose that land-ice excavated our deepest lakebasins out of solid rock. A terrestrial surface of crystalline rock, long exposed to the atmosphere, or covered with vegetation and humus, may be so deeply corroded as, for two or three hundred feet downward, to be converted into mere loose detritus, through which the harder undecomposed veins and ribs still run. Such is the case in Brazil, and such may have been also the case in some glaciated regions before the glaciers settled down upon them. This superficial corrosion, as shown by Pumpelly, may have been very unequal, so that when the decomposed material was removed, numerous hollows would be revealed. The ice may thus have had much of its work already done

${ }^{1}$ Lough Neagh has been produced by subsidence, probably since the Glacial Period. See Ancient Volcanoes of Great Britain, vol. ii. p. 448 . 


\section{I50 ORIGIN OF SCENERY OF BRITAIN}

for it, and would be mainly employed in clearing out the corroded debris, though likewise finally deepening, widening, and smoothing the basins in the solid rock.

THE HILLS AND ESCARPMENTS.

The Hills and Hill-groups of Britain have all emerged during the gradual denudation of the country, and owe their prominence to the greater durability of their materials as compared with those of the surrounding lower grounds. They thus represent various stages in the general lowering of the surface. In many cases they consist of local masses of hard rock. Such is the structure of the prominent knobs of Pembrokeshire and of Central Scotland, where masses of eruptive rock, formerly deeply buried under superincumbent formations, have been laid bare by denudation. In connection with such eruptive bosses, attention should be given to the 'dykes' so plentiful in the north of England and Ireland, and over most of Scotland. In numerous instances, the dykes run along the crests of hills, and also cross wide and deep valleys. Had the present topography existed at the time of their protrusion, the molten basalt would have flowed down the hill-slopes and filled up the valleys. As this never occurs, and as there is good evidente that a vast number of the dykes are not of higher antiquity than the older Tertiary periods, we may conclude that the present configuration of the country has, on the whole, been developed since older Tertiary time-a deduction in harmony with that already announced from other independent evidence.

Escarpments are the prominent outcrops of flat or 
gently inclined strata, exposed by denudation. They may be regarded as the steep edges of hills in retreat. The British islands abound in admirable examples of all ages from early Palæozoic rocks down to Tertiary deposits, and of every stage of development, from an almost unbroken line of cliff to scattered groups of islet-like fragments. The retreat of our escarpments can be well studied along the edge of the Jurassic belt from Dorsetshire to the headlands of Yorkshire, likewise in the course of the edge of the Chalk across the island. Not less suggestive are some of the escarpments of more ancient rocks, such as those of the older Palæozoic limestones, the Old Red Sandstone of Wales, the Carboniferous Limestone and Millstone Grit of Yorkshire, and the Coal Measures of the Irish plain. Our volcanic escarpments are likewise full of interest, as displayed in those of the Lower Old Red Sandstone along both sides of the Tay, in those of the Carboniferous system in Stirlingshire, Ayrshire, Bute, and Roxburghshire, and in those of the Tertiary series in Antrim and the Inner Hebrides.

\section{THE PLAINS.}

The Plains of Britain, like those elsewhere, must be regarded as local base-levels of denudation, that is, areas where, on the whole, denudation has ceased, or at least has become much less than deposit. Probably in all cases the areas they occupy have been levelled by denudation. Usually a greater or less depth of detrital material has been spread over them, and it is the more or less level surface of these superficial accumulations that generally forms the plain. But in 


\section{52 ORIGIN OF SCENERY OF BRITAIN}

some instances, such as the flats of the Weald Clay and the Chalk of Salisbury Plain, there is hardly any such cover of detritus, the denuded surface of underlying rock forming the actual floor on which the vegetable soil rests.

Our plains, if classed according to the circumstances of their origin, may be conveniently regarded as (I) river plains-strips of meadow-land bordering the streams, and not infrequently rising in a succession of terraces to a considerable height above the present level of the water; (2) lake plains-tracts of arable ground occupying the sites of former lakes, and of which the number is ever on the increase, owing to the filling-up of the basins with sediment; (3) plains consisting of portions of upraised sea-floors - partly eroded rock-platforms, but mostly flat selvages of alluvial ground, formed of littoral materials deposited when the land lay below its present level: in the northern estuaries these raised beaches spread out as broad carse-lands, such as those of the Tay, Forth, and Clyde ; (4) glacial drift plains - tracts over which the clays, sands, and gravels spread out during the Ice-Age form the existing surface ; (5) plains of subaerial denudation which have been levelled by rain and other atmospheric agents, especially upon tracts of rock of fairly uniform resistance, such as the soft clays and sands of the Secondary and Tertiary formations; (6) submarine plains-the present floor of the North Sea and of the Irish Sea, which must be regarded as essentially part of the terrestrial area of Europe.

When plains remain stationary at low levels, they 
may continue for an indefinite period with no material change of surface. But, should they be upraised, the elevation, by increasing the slope of the streams, augments their erosive power, and enables them once more to deepen their channels. Hence, plains like that of the New Forest, which have been trenched by the water-courses that traverse them, may with probability be assigned to a time when the land stood at a lower level than it occupies at present. In this connection the successive river-terraces of the country deserve attention. They may be due not to the mere unaided work of the rivers, but to the cooperation of successive uplifts. It would be an interesting inquiry to correlate the various river-terraces throughout the country, for the purpose of discovering whether they throw any light on the conditions under which the most recent uprise of the country took place. That the elevation proceeded intermittently, with long pauses between the movements, is shown by the succession of raised beaches. It may be possible to establish a somewhat similar proof among our riverterraces.

The submarine plains are by far the most extensive within the British area. The tendency of tidal scour and deposit must modify the form of the bottom. In the case of the North Sea, for example, this great basin of water is obviously being slowly filled up by the deposit of sediment over its floor. A vast amount of mud and silt is borne into it by the rivers of western continental Europe, and of the eastern coast of Britain; while at the same time the waves are cutting away the land on both sides of this sea 


\section{I54 ORIGIN OF SCENERY OF BRITAIN}

and swallowing up the waste. We have only to contrast the colour of the Atlantic on the west of Ireland or of Scotland with that of the North Sea, to be assured of the wide diffusion of fine mud in the water of the latter. There is practically no outlet for the detritus that is thus poured into the basin of the North Sea. From the north a vast body of tidal water enters between Scotland and Norway, and travelling southward, aided by the strong northerly winds, sweeps the detritus in the same direction. On the other hand, another narrower and shallower tidal stream enters from the Strait of Dover, and, aided by the southwest winds, drives the sediment northward. Yet, making every allowance for the banks and shoals which this accumulating deposit has already formed, we can still, without much difficulty, recognise the broader features of the old land-surface that now lies submerged beneath the North Sea. As already mentioned (p. I 3 I), it presents two plains or platforms, of which the southern has an average level of perhaps a little more than roo feet below the surface of the water. This upper plain ends northward in a shelving bank, probably the prolongation of the Jurassic escarpment of Yorkshire, and is succeeded by the far wider northern plain, which lies from Io0 to I 50 feet lower, and gradually slopes northward until it is trenched by the great south Scandinavian submerged fjord. The drainage-lines of the united Rhine, Thames, etc., on the one side, and the Elbe, Weser, etc., on the other can still be partially traced on that sea-floor. The site of the Irish Sea was probably once a terrestrial plain dotted with lakes. This land-surface appears to 
have been submerged before the whole of the present fauna and flora had reached Ireland.

\section{THE COAST-LINE.}

Some of the most characteristic and charming scenery of the British Islands is to be found along their varied seaboard. Coast scenery appears to depend for its distinctive features upon (I) the form of the ground at the time when by emergence or submergence the present level was established; (2) the composition and structure of the shore-rocks; (3) the direction of the prevalent winds, and the relative potency of subaërial and marine denudation.

The British coast-line presents three distinct phases: in many places it is retreating; in others it is advancing; while in a few it may be regarded as practically stationary. As examples of retreat, the shores of a large part of the east of England may be cited. In Holderness, for instance, a strip of land more than a mile broad has been carried away during the last eight centuries. Even since the Ordnance Survey maps were published in $185 \mathrm{I}$, more than 500 feet have in some places been removed, the rate of demolition being here and there as much as five yards in a year. The advance of the coast takes place chiefly in sheltered bays, or behind or in front of projecting headlands and piers, and is due in large measure, to the deposit of material which has been removed by the sea from adjoining shores. The amount of land thus added does not compensate for the quantity carried away, so that the total result is a perceptible annual loss. The best examples of a 


\section{56 ORIGIN OF SCENERY OF BRI'TAIN}

stationary coast-line, where there is no appreciable erosion by the waves and little visible accumulation of detritus, are to be found among the land-locked fjords or sea-inlets of the west coast of Scotland. In these sheltered recesses the smooth striated rocks of the Ice-Age slip under the sea, with their characteristic glaciated surfaces still so fresh that it is hard to believe that a long lapse of ages has passed away since the glaciers left them.

The remarkable contrast between the scenery of the eastern and western coast-line of the British Islands arises partly from the preponderance of harder rocks on the west side, but probably in large measure upon the greater extent of the submergence of the western seaboard, whereby the sea has been allowed to penetrate far inland by fjords which were formerly glens and open straths.

The details of coast-scenery vary with the rock in which they are developed. Nowhere can the effects of each leading type of rock upon landscape be more instructively studied than along the sea-margin. As distinct types of coast-scenery, reference may be made to sea-cliffs and rocky shores of granite, gneiss, basalt, massive sandstone and flagstone, limestone, alternations of sandstone shale or other strata, and boulder-clay, and to the forms assumed by detrital accumulations such as sand-dunes, shingle-banks, and flats of sand or mud.

The concluding portion of the last lecture was devoted to an indication of the connection between the scenery of a country and the history and temperament of the people. This subject was considered from four 


\section{CONCLUSION}

points of view, the influence of landscape and geological structure being traced in the distribution of races, in national history, in industrial and commercial progress, and in national temperament and literature. ${ }^{1}$

${ }^{1}$ Some of these subjects were subsequently more fully treated in the three foregoing essays of the present volume. 


\section{V \\ The Centenary of Hutton's ' Theory of the Earth'1}

IN its beneficent progress through these islands the British Association for the Advancement of Science now for the fourth time receives a welcome in this ancient capital. Once again, under the shadow of these antique towers, crowded memories of a romantic past fill our thoughts. The stormy annals of Scotland seem to move in procession before our eyes as we walk these streets, whose names and traditions have been made familiar to the civilised world by the genius of literature. At every turn, too, we are reminded, by the monuments which a grateful city has erected, that for many generations the pursuits which we are now assembled to foster have had here their congenial home. Literature, philosophy, science, have each in turn been guided by the influence of the great masters who have lived here, and whose renown is the brightest gem in the chaplet around the brow of this 'Queen of the North.'

1 The Address of the President of the British Association for the Advancement of Science at the Meeting held in Edinburgh, I 892. 
Lingering for a moment over these local associations, we shall find a peculiar appropriateness in the time of this renewed visit of the Association to Edinburgh. A hundred years ago a remarkable group of men was discussing here the great problem of the history of the earth. James Hutton, after many years of travel and reflection, had communicated to the Royal Society of this city, in the year 1785 , the first outlines of his famous Theory of the Earth. Among those with whom he took counsel in the elaboration of his doctrines were Black, the illustrious discoverer of 'fixed air' and 'latent heat'; Clerk, the sagacious inventor of the system of breaking the enemy's line in naval tactics; Hall, whose fertile ingenuity devised the first system of experiments in illustration of the structure and origin of rocks; and Playfair, through whose sympathetic enthusiasm and literary skill Hutton's views came ultimately to be understood and appreciated by the world at large. With these friends, so well able to comprehend and criticise his efforts to pierce the veil that shrouded the history of this globe, he paced the streets amid which we are now gathered together; with them he sought the crags and ravines around us, wherein Nature has laid open so many impressive records of her past; with them he sallied forth on those memorable expeditions to distant parts of Scotland, whence he returned laden with treasures from a field of observation which, though now so familiar, was then almost untrodden. The centenary of Hutton's Theory of the Earth is an event in the annals of science which seems most fittingly 
celebrated by a meeting of the British Association in Edinburgh.

In choosing from among the many subjects which might properly engage your attention on the present occasion, I have thought that it would not be inappropriate nor uninteresting to consider the more salient features of that 'Theory,' and to mark how much in certain departments of inquiry has sprung from the fruitful teaching of its author and his associates.

It was a fundamental doctrine of Hutton and his school that this globe has not always worn the aspect which it bears at present; that, on the contrary, proofs may everywhere be culled that the land which we now see has been formed out of the wreck of an older land. Among these proofs, the most obvious are supplied by some of the more familiar kinds of rock, which teach us that, though they are now portions of the dry land, they were originally sheets of gravel, sand, and mud, which had been worn from the face of long-vanished continents, and after being spread out over the floor of the sea were consolidated into compact stone, and were finally broken up and raised once more to form part of the dry land. This cycle of change involved two great systems of natural processes. On the one hand, men were taught that by the action of running water the materials of the solid land are in a state of continual decay and transport to the ocean. On the other hand, the ocean-floor is liable from time to time to be upheaved by some 


\section{THE PRESEN'T KEY TO 'THE PAST I6I}

stupendous internal force akin to that which gives rise to the volcano and the earthquake. Hutton further perceived that not only had the consolidated sediments been disrupted and elevated, but that masses of molten rock had been thrust upward among them, and had cooled and crystallised in large bodies of granite and other eruptive materials, which form so prominent a feature on the earth's surface.

As a further special characteristic, this philosophical system sought, in the changes now in progress on the earth's surface, an explanation of those which occurred in older times. Its founder refused to invent causes or modes of operation, for those with which he was familiar seemed to him adequate to solve the problems with which he attempted to deal. Nowhere was the profoundness of his insight more astonishing than in the clear, definite way in which he proclaimed and reiterated his doctrine, that every part of the surface of the continents, from mountaintop to seashore, is continually undergoing decay, and is thus slowly travelling to the sea. He saw that no sooner will the sea-floor be elevated into new land than it must necessarily become a prey to this universal and unceasing degradation. He perceived that, as the transport of disintegrated material is carried on chiefly by running water, rivers must slowly dig out for themselves the channels in which they flow, and thus that a system of valleys, radiating from the water-parting of a country, must necessarily result from the descent of the streams from the mountain crests to the sea. $\mathrm{He}$ discerned that this ceaseless and widespread decay would eventually lead to the entire demolition of the 
dry land, but he contended that from time to time this catastrophe is prevented by the operation of the underground forces, whereby new continents are upheaved from the bed of the ocean. And thus in his system a due proportion is maintained between land and water, and the condition of the earth as a habitable globe is preserved.

A theory of the earth so simple in outline, so bold in conception, so full of suggestion, and resting on so broad a base of observation and reflection, ought, we might think, to have commanded at once the attention of men of science, even if it did not immediately awaken the interest of the outside world; but, as Playfair sorrowfully admitted, it attracted notice only very slowly, and several years elapsed before anyone showed himself publicly concerned about it, either as an enemy or a friend. Some of its earliest critics assailed it for what they asserted to be its irreligious tendency - an accusation which Hutton repudiated with much warmth. The sneer levelled by Cowper a few years earlier at all inquiries into the history of the universe was perfectly natural and intelligible from that poet's point of view (p. 128). There was then a widespread belief that this world came into existence some six thousand years ago, and that any attempt greatly to increase that antiquity was meant as a blow to the authority of Holy Writ. So far, however, from aiming at the overthrow of orthodox beliefs, Hutton evidently regarded his 'Theory' as an important contribution in aid of natural religion. $\mathrm{He}$ dwelt with unfeigned pleasure on the multitude of proofs which he was able to accumulate of an 
orderly design in the operations of nature, decay and renovation being so nicely balanced as to maintain the habitable condition of the planet. But as he refused to admit the predominance of violent action in terrestrial changes, and on the contrary contended for the efficacy of the quiet, continuous processes which we can even now see at work around us, he was constrained to require an unlimited duration of past time for the production of those revolutions of which he perceived such clear and abundant proofs in the crust of the earth. The general public, however, failed to comprehend that the doctrine of the high antiquity of the globe was not inconsistent with the comparatively recent appearance of man-a distinction which seems so obvious now.

Hutton died in 1797, beloved and regretted by the circle of friends who had learnt to appreciate his estimable character and to admire his genius, but with little recognition from the world at large. Men knew not then that a great master had passed away from their midst, who had laid broad and deep the foundations of a new science; that his name would become a household word in after generations, and that pilgrims would come from distant lands to visit the scenes from which he drew his inspiration.

Many years might have elapsed before Hutton's teaching met with wide acceptance, had its recognition depended solely on the writings of the philosopher himself. For, despite his firm grasp of general principles and his mastery of the minutest details, he had acquired a literary style which, it must be admitted, was singularly unattractive. Fortunately for his fame, as well 
as for the cause of science, his devoted friend and disciple, Playfair, at once set himself to draw up an exposition of Hutton's views. After five years of labour on this task there appeared the classic Illustrations of the Huttonian Theory, a work which for luminous treatment and graceful diction stands still without a rival in English geological literature. Though professing merely to set forth his friend's doctrines, Playfair's treatise was in many respects an original contribution to science of the highest value. It placed for the first time in the clearest light the whole philosophy of Hutton regarding the history of the earth, and enforced it with a wealth of reasoning and copiousness of illustration which obtained for it a wide appreciation. From long converse with Hutton, and from profound reflection himself, Playfair gained such a comprehension of the whole subject that, discarding the non-essential parts of his master's teaching, he was able to give so lucid and accurate an exposition of the general scheme of Nature's operations on the surface of the globe, that with only slight corrections and expansions his treatise may serve as a text-book to-day. In some respects, indeed, his volume was long in advance of its time. Only, for example, within the lifetime of the present generation has the truth of his teaching in regard to the origin of valleys been generally admitted.

Various causes contributed to retard the progress of the Huttonian doctrines. Especially potent was the influence of the teaching of Werner, who, though he perceived that a definite order of sequence could be recognised among the materials of the earth's crust, 
had formed singularly narrow conceptions of the great processes whereby that crust has been built up. His enthusiasm, however, fired his disciples with the zeal of proselytes, and they spread themselves over Europe to preach everywhere the artificial system which they had learnt in Saxony. By a curious fate Edinburgh became one of the great headquarters of Wernerism. The friends and followers of Hutton found themselves attacked in their own city by zealots who, proud of superior mineralogical acquirements, turned their most cherished ideas upside down and assailed them in the uncouth jargon of Freiberg. Inasmuch as subterranean heat had been invoked by Hutton as a force largely instrumental in consolidating and upheaving the ancient sediments that now form so great a part of the dry land, his followers were nicknamed Plutonists. On the other hand, as the agency of water was almost alone admitted by Werner, who believed the rocks of the earth's crust to have been chiefly chemical precipitates from a primeval universal ocean, those who adopted his views received the equally descriptive name of Neptunists. The battle of these two contending schools raged fiercely here for some years, and though mainly from the youth, zeal, and energy of Jameson, and the influence which his position as Professor in the University gave him, the Wernerian doctrines continued to hold their place, they were eventually abandoned even by Jameson himself, and the debt due to the memory of Hutton and Playfair was tardily acknowledged.

The pursuits and the quarrels of philosophers have from early times been a favourite subject of merriment 
to the outside world. Such a feud as that between the Plutonists and Neptunists would be sure to furnish abundant matter for the gratification of this propensity. Turning over the pages of Kay's Portraits, where so much that was distinctive of Edinburgh society a hundred years ago is embalmed, we find Hutton's personal peculiarities and pursuits touched off in goodhumoured caricature. In one plate he stands with arms folded and hammer in hand, meditating on the face of a cliff, from which rocky prominences in shape of human faces, perhaps grotesque likenesses of his scientific opponents, grin at him. In another engraving he sits in conclave with his friend Black, possibly arranging for that famous banquet of garden-snails which the two worthies had persuaded themselves to look upon as a strangely neglected form of human food. More than a generation later, when the Huttonists and Wernerists were at the height of their antagonism, the humorous side of the controversy did not escape the notice of the author of Waverley, who, you will remember, when he makes Meg Dods recount the various kinds of wise folk brought by Lady Penelope Pennfeather from Edinburgh to St. Ronan's Well, does not forget to include those who ' rin uphill and down dale, knapping the chucky-stanes to pieces wi' hammers, like sae mony road-makers run daft, to see how the warld was made.'

Among the names of the friends and followers of Hutton there is one which on this occasion deserves to be held in especial honour, that of Sir James Hall, of Dunglass. Having accompanied Hutton in some of his excursions, and having discussed with him the 
problems presented by the rocks of Scotland, Hall was familiar with the views of his master, and was able to supply him with fresh illustrations of them from different parts of the country. Gifted with remarkable originality and ingenuity, he soon perceived that some of the questions involved in the theory of the earth could probably be solved by direct physical experiment. Hutton, however, mistrusted any attempt 'to judge of the great operations of Nature by merely kindling a fire and looking into the bottom of a little crucible.' Out of deference to this prejudice, Hall delayed to carry out his intention during Hutton's lifetime. But afterwards he instituted a remarkable series of researches which are memorable in the history of science as the first methodical endeavour to test the value of geological speculation by an appeal to actual experiment. The Neptunists, in ridiculing the Huttonian doctrine that basalt and similar rocks had once been molten, asserted that, had such been their origin, these masses would now be found in the condition of glass or slag. Hall, however, triumphantly vindicated his friend's view by proving that basalt could be fused and thereafter by slow cooling could be made to resume a stony texture. Again, Hutton had asserted that under the vast pressures which must be effective deep within the earth's crust, chemical reactions must be powerfully influenced, and that under such conditions even limestone may conceivably be melted without losing its carbonic acid. Various specious arguments had been adduced against this proposition, but by an ingeniously devised series of experiments Hall succeeded in converting limestone under great pressure into a kind of 
marble, and even in fusing it, and found that it then acted vigorously on other rocks. These admirable researches, which laid the foundations of experimental geology, constitute not the least memorable of the services rendered by the Huttonian school to the progress of science.

Clear as was the insight and sagacious the inferences of these great masters in regard to the history of the globe, their vision was necessarily limited by the comparatively narrow range of ascertained fact which up to their time had been established. They taught men to recognise that the present world is built of the ruins of an earlier one, and they explained with admirable perspicacity the operation of the processes whereby the degradation and renovation of land are brought about. But they never dreamed that a long and orderly series of such successive destructions and renewals had taken place, and had left their records in the crust of the earth. They never imagined that from these records it would be possible to establish a determinate chronology that could be read everywhere, and applied to the elucidation of the remotest quarter of the globe. It was by the memorable observations and generalisations of William Smith that this vast extension of our knowledge of the past history of the earth became possible. While the Scottish philosophers were building up their theory here, Smith was quietly ascertaining by extended journeys that the stratified rocks of the west of England occur in a definite sequence, and that each well-marked group of them can be discriminated from the others and identified across the country by means of its 
enclosed organic remains. It is nearly a hundred years since he made known his views, so that by a curious coincidence we may fitly celebrate on this occasion the centenary of William Smith as well as that of James Hutton. No single discovery has ever had a more momentous and far-reaching influence on the progress of a science than that law of organic succession which Smith established. At first it served merely to determine the order of the stratified rocks of England. But it soon proved to possess a worldwide value, for it was found to furnish the key to the structure of the whole stratified crust of the earth. It showed that within that crust lie the chronicles of a long history of plant and animal life upon this planet, it supplied the means of arranging the materials for this history in true chronological sequence, and it thus opened out a magnificent vista through a vast series of ages, each marked by its own distinctive types of organic life, which, in proportion to their antiquity, departed more and more from the aspect of the living world.

Thus a hundred years ago, by the brilliant theory of Hutton and the fruitful generalisation of Smith, the study of the earth received in our country the impetus which has given birth to the modern science of geology.

To review the marvellous progress which this science has made during the first century of its existence would require not one but many hours for adequate treatment. The march of discovery has advanced along a multitude of different paths, and the domains of Nature which have been included within the growing 
territories of human knowledge have been many and ample. Nevertheless, there are certain departments of investigation to which we may profitably restrict our attention on the present occasion, and wherein we may see how the leading principles that were proclaimed in this city a hundred years ago have germinated and borne fruit all over the world.

From the earliest times the natural features of the earth's surface have arrested the attention of mankind. The rugged mountain, the cleft ravine, the scarped cliff, the solitary boulder, have stimulated curiosity and prompted many a speculation as to their origin. The shells embedded by millions in the solid rocks of hills far removed from the sea have still further pressed home these 'obstinate questionings.' But for many long centuries the advance of inquiry into such matters was arrested by the paramount influence of orthodox theology. It was not merely that the Church opposed itself to the simple and obvious interpretation of these natural phenomena. So implicit had faith become in the accepted views of the earth's age and of the history of creation, that even laymen of intelligence and learning set themselves, unbidden and in perfect good faith, to explain away the difficulties which Nature so persistently raised up, and to reconcile her teachings with those of the theologians. In the various theories thus originating, the amount of knowledge of natural law usually stood in inverse ratio to the share played in them by an uncontrolled imagination. The speculations, for example, of Burnet, Whiston, Whitehurst, and others in this country, cannot be read now without a smile. In 
no sense were they scientific researches; they can only be looked upon as exercitations of learned ignorance. Springing mainly out of a laudable desire to promote what was believed to be the cause of true religion, they helped to retard inquiry, and exercised in that respect a baneful influence on intellectual progress.

It is the special glory of the Edinburgh school of geology to have cast aside all this fanciful trifling. Hutton boldly proclaimed that it was no part of his philosophy to account for the beginning of things. His concern lay only with the evidence furnished by the earth itself as to its origin. With the intuition of true genius he early perceived that the only solid basis from which to explore what has taken place in bygone time is a knowledge of what is taking place to-day. He thus founded his system upon a careful study of the processes whereby geological changes are now brought about. He felt assured that Nature must be consistent and uniform in her working, and that only in proportion as her operations at the present time are watched and understood will the ancient history of the earth become intelligible. Thus, in his hands, the investigation of the Present became the key to the interpretation of the Past. The establishment of this great truth was the first step towards the inauguration of a true science of the earth. The doctrine of the uniformity of causation in Nature became the fruitful principle on which the structure of modern geology could be built up.

Fresh life was now breathed into the study of the earth. A new spirit seemed to animate the advance 
along every pathway of inquiry. Facts that had long been familiar came to possess a wider and deeper meaning when their connection with each other was recognised as parts of one great harmonious system of continuous change. In no department of Nature, for example, was this broader vision more remarkably displayed than in that wherein the circulation of water between land and sea plays the most conspicuous part. From the earliest times men had watched the coming of clouds, the fall of rain, the flow of rivers, and had recognised that on this nicely adjusted machinery the beauty and fertility of the land depend. But they now learnt that this beauty and fertility involve a continual decay of the terrestrial surface; that the soil is a measure of this decay, and would cease to afford us maintenance were it not continually removed and renewed; that through the ceaseless transport of soil by rivers to the sea the face of the land is slowly lowered in level and carved into mountain and valley, and that the materials thus borne outwards to the floor of the ocean are not lost, but accumulate there to form rocks, which in the end will be upraised into new lands. Decay and renovation, in well-balanced proportions, were thus shown to be the system on which the existence of the earth as a habitable globe had been established. It was impossible to conceive that the economy of the planet could be maintained on any other basis. Without the circulation of water the life of plants and animals would be impossible, and with that circulation the decay of the surface of the land and the renovation of its disintegrated materials are necessarily involved. 
As it is now, so must it have been in past time. Hutton and Playfair pointed to the stratified rocks of the earth's crust as demonstrations that the same processes which are at work to-day have been in operation from a remote antiquity. By thus placing their theory on a basis of actual observation, and providing in the study of existing operations a guide to the interpretation of those in past times, they rescued the investigation of the history of the earth from the speculations of theologians and cosmologists, and established a place for it among the recognised inductive sciences. To the guiding influence of their philosophical system the prodigious strides made by modern geology are in large measure to be attributed. And here in their own city, after the lapse of a hundred years, let us offer to their memory the grateful homage of all who have profited by their labours.

But while we recognise with admiration the farreaching influence of the doctrine of uniformity of causation in the investigation of the history of the earth, we must upon reflection admit that the doctrine has been pushed to an extreme perhaps not contemplated by its original founders. To take the existing conditions of Nature as a platform of actual knowledge from which to start in an inquiry into former conditions was logical and prudent. Obviously, however, human experience, in the few centuries during which attention has been turned to such subjects, has been too brief to warrant any dogmatic assumption that the various natural processes must have been carried on in the past with the same energy and at the same rate as they are carried on now. Variations in energy 
might have been legitimately conceded as possible, though not to be allowed without reasonable proof in their favour. It was right to refuse to admit the operation of speculative causes of change when the phenonema were capable of natural and adequate explanation by reference to causes that can be watched and investigated. But it was an error to take for granted that no other kind of process or influence, nor any variation in the rate of activity save those of which man has had actual cognisance, has played a part in the terrestrial economy. The uniformitarian writers laid themselves open to the charge of maintaining a kind of perpetual motion in the machinery of Nature. They could find in the records of the earth's history no evidence of a beginning, no prospect of an end. They saw that many successive renovations and destructions had been effected on the earth's surface, and that this long line of vicissitudes formed a series of which the earliest were lost in antiquity, while the latest were still in progress towards an apparently illimitable future.

The discoveries of William Smith, had they been adequately understood, would have been seen to offer a corrective to this rigidly uniformitarian conception, for they revealed that the crust of the earth contains the long record of an unmistakable order of progression in organic types. They proved that plants and animals have varied widely in successive periods of the earth's history, the present condition of organic life being only the latest phase of a long preceding series, each stage of which recedes further from the existing aspect of things as we trace it backward into the past. 
And though no relic had yet been found, or indeed was ever likely to be found, of the first living things that appeared upon the earth's surface, the manifest simplification of types in the older formations pointed irresistibly to some beginning from which the long procession had taken its start. If then it could thus be demonstrated that there had been upon the globe an orderly march of living forms, from the lowliest grades in early times to man himself to-day, and thus that in one department of her domain, extending through the greater portion of the records of the earth's history, Nature had not been uniform but had followed a vast and noble plan of evolution, surely it might have been expected that those who discovered and made known this plan would seek to ascertain whether some analogous physical progression from a definite beginning might not be discernible in the framework of the globe itself.

But the early masters of the science laboured under two great disadvantages. In the first place, they found the oldest records of the earth's history so broken up and defaced as to be no longer legible. And in the second place, they lived under the spell of that strong reaction against speculation which followed the bitter controversy between the Neptunists and Plutonists in the earlier decades of the century. They considered themselves bound to search for facts, not to build up theories; and as in the crust of the earth they could find no facts which threw any light upon the primeval constitution and subsequent development of our planet, they shut their ears to any theoretical interpretations that might be offered from other departments of 
science. It was enough for them to maintain, as Hutton had done, that in the visible structure of the earth itself no trace can be found of the beginning of things, and that the oldest terrestrial records reveal no physical conditions essentially different from those in which we still live. They doubtless listened with interest to the speculations of Kant, Laplace, and Herschel, on the probable evolution of nebulæ, suns, and planets, but it was with the languid interest attaching to ideas that lay outside of their own domain of research. They recognised no practical connection between such speculations and the data furnished by the earth itself as to its own history and progress.

This curious lethargy with respect to theory, on the part of men who were popularly regarded as among the most speculative followers of science, would probably not have been speedily dispelled by any discovery made within their own field of observation. Even now, after many years of the most diligent research, the first chapters of our planet's history remain undiscovered or undecipherable. On the great terrestrial palimpsest the earliest inscriptions seem to have been hopelessly effaced by those of later ages. But the question of the primeval condition and subsequent history of the planet might be considered from the side of astronomy and physics. And it was by investigations of this nature that the geological torpor was eventually dissipated. To our illustrious former President, Lord Kelvin, who occupied this chair when the Association last met in Edinburgh, is mainly due the rousing of attention to this subject. By the most convincing arguments he showed how impossible it was to believe 
in the extreme doctrine of uniformitarianism. And though, owing to uncertainty in regard to some of the data, wide limits of time were postulated by him, he insisted that within these limits the whole evolution of the earth and its inhabitants must have been comprised. While, therefore, the geological doctrine that the present order of Nature must be our guide to the interpretation of the past remained as true and fruitful as ever, it had now to be widened by the reception of evidence furnished by a study of the earth as a planetary body. The secular loss of heat, which demonstrably takes place both from the earth and the sun, made it quite certain that the present could not have been the original condition of the system. This diminution of temperature with all its consequences is not a mere matter of speculation, but a physical fact of the present time as much as any of the familiar physical agencies that affect the surface of the globe. It points with unmistakable directness to that beginning of things of which Hutton and his followers could find no sign.

Another modification or enlargement of the uniformitarian doctrine was brought about by continued investigation of the terrestrial crust and consequent increase of knowledge respecting the history of the earth. Though Hutton and Playfair believed in periodical catastrophes, and indeed required these to recur in order to renew and preserve the habitable condition of our planet, their successors gradually came to view with repugnance any appeal to abnormal, and especially to violent manifestations of terrestrial vigour, and even persuaded themselves that such slow and 
comparatively feeble action as is now witnessed by man could alone be recognised in the evidence from which geological history must be compiled. Well do I remember in my own boyhood what a cardinal article of faith this prepossession had become. We were taught by our great and honoured master, Lyell, to believe implicitly in gentle and uniform operations, extended over indefinite periods of time, though possibly some, with the zeal of partisans, carried this belief to an extreme which Lyell himself did not approve. The most stupendous marks of terrestrial disturbance, such as the structure of great mountain chains, were deemed to be more satisfactorily accounted for by slow movements prolonged through indefinite ages than by any sudden convulsion.

What the more extreme members of the uniformitarian school failed to perceive was the absence of all evidence that terrestrial catastrophes even on a colossal scale might not be a part of the present economy of this globe. Such occurrences might never seriously affect the whole earth at one time, and might return at such wide intervals that no example of them has yet been chronicled by man. But that they have occurred again and again, and even within comparatively recent geological times, hardly admits of serious doubt. How far at different epochs and in various degrees they may have included the operation of cosmical influences lying wholly outside the planet, and how far they have resulted from movements within the body of the planet itself, must remain for further inquiry. Yet the admission that they have played a part in geological history may be 
freely made without impairing the real value of the Huttonian doctrine, that in the interpretation of this history our main guide must be a knowledge of the existing processes of terrestrial change.

As the most recent and best known of these great transformations, the Ice-Age stands out conspicuously before us. If any one sixty years ago had ventured to affirm that, at no very distant era in the past, the snows and glaciers of the Arctic regions stretched southwards to the Bristol Channel and the basin of the Thames, he would have been treated as a mere visionary theorist. Many of the facts to which he would have' appealed in support of his statement were already well known, but they had received various other interpretations. By some observers, notably by Hutton's friend, Sir James Hall, they were believed to indicate violent debacles of water that swept over the face of the land. By others they were attributed to the strong tides and currents of the sea when the land stood at a lower level. The uniformitarian school of Lyell had no difficulty in elevating or depressing land to any required extent. Indeed, when we consider how averse these philosophers were to admit any kind or degree of natural operation other than those of which there was some human experience, we may well wonder at the boldness with which, on sometimes the slenderest evidence, they made land and sea change places, on the one hand submerging mountain-ranges, and on the other placing great barriers of land where a deep ocean rolls. They took such liberties with geography because only well-, established processes of change were invoked in the 
operations. Knowing that during the passage of an earthquake a territory bordering the sea may be upraised or sunk a few feet, they drew the sweeping inference that any amount of upheaval or depression of any part of the earth's surface might be claimed in explanation of geological problems. The progress of inquiry, started here by Agassiz, while it has somewhat curtailed this geographical license, has now made known in great detail the strange story of the Ice-Age.

There cannot be any doubt that after man had become a denizen of the earth, a great physical change came over the northern hemisphere. The climate, which had previously been so mild that evergreen trees flourished within ten or twelve degrees of the north pole, now became so severe that vast sheets of snow and ice covered the north of Europe and crept southward beyond the south coast of Ireland, almost as far as the southern shores of England, and across the Baltic into France and Germany. This Arctic transformation was not an episode that lasted merely a few seasons, and left the land to resume thereafter its ancient aspect. With various successive fluctuations it must have endured for many thousands of years. When it began to disappear it probably faded away as slowly and imperceptibly as it had advanced, and when it finally vanished it left Europe and North America profoundly changed in the character alike of their scenery and of their inhabitants. The rugged, rocky contours of earlier times were ground smooth and polished by the march of the ice across them, while the lower grounds were buried under wide and thick sheets of clay, gravel, and 
sand, left behind by the melting ice. The varied and abundant flora which had spread so far within the Arctic circle was driven away into more southern and less ungenial climes. But most memorable of all was the extirpation of the prominent large animals which, before the advent of the ice, had roamed over Europe. The lions, hyænas, wild horses, hippopotami and other creatures either became entirely extinct or were driven into the Mediterranean basin and into Africa. In their place came northern forms-the reindeer, glutton, musk ox, woolly rhinoceros, and mammoth.

Such a marvellous transformation in climate, in scenery, in vegetation, and in inhabitants, within what was after all but a brief portion of geological time, though it may have involved no sudden or violent convulsion, is surely entitled to rank as a catastrophe in the history of the globe. It was possibly brought about mainly if not entirely by the operation of forces external to the earth. No similar calamity having befallen the continents within the time during which man has been recording his experience, the Ice-Age might be cited as a contradiction to the doctrine of uniformity. And yet it manifestly arrived as part of the established order of Nature. Whether or not we grant that other ice-ages preceded the last great one, we must admit that the conditions under which it arose, so far as we know them, might conceivably have occurred before and may occur again. The various agencies called into play by the extensive refrigeration of the northern hemisphere were not different from those with which we are familiar. Snow 
fell and glaciers crept as they do to-day. Ice scored and polished rocks exactly as it still does among the Alps and in Norway. There was nothing abnormal in the phenomena save the scale on which they were manifested. And thus, taking a broad view of the whole subject, although we cannot yet explain the origin of the catastrophe, we see in its progress the operation of natural processes which we know to be integral parts of the machinery whereby the surface of the earth is still continually transformed.

Among the debts which science owes to the Huttonian school, not the least memorable is the promulgation of the first well-founded conceptions of the high antiquity of the globe. Some six thousand years had previously been usually believed to comprise the whole life of the planet, and indeed of the entire universe. When the curtain was then first raised that had veiled the history of the earth, and men, looking beyond the brief span within which they had supposed that history to have been transacted, beheld the records of a long vista of ages stretching far away into a dim illimitable past, the prospect vividly impressed their imagination. Astronomy had made known the immeasurable fields of space; the new science of geology seemed now to reveal boundless distances of time. The more the terrestrial chronicles were studied the farther could the eye range into an antiquity so vast as to defy all attempts to measure or define it. The progress of research continually furnished additional evidence of the enormous duration of the ages that preceded the coming of man, while, as knowledge increased, periods that were 


\section{NO TRACE OF A BEGINNING I 83}

thought to have followed each other consecutively were found to have been separated by prolonged intervals of time. Thus the idea arose and gained universal acceptance that, just as no boundary could be set to the astronomer in his free range through space, so the whole of bygone eternity lay open to the requirements of the geologist. Playfair, re-echoing and expanding Hutton's language, had declared that neither among the records of the earth nor in the planetary motions can any trace be discovered of the beginning or of the end of the present order of things; that no symptom of infancy or of old age has been allowed to appear on the face of Nature, nor any sign by which either the past or the future duration of the universe can be estimated; and that although the Creator may put an end, as $\mathrm{He}$ no doubt gave a beginning, to the present system, such a catastrophe will not be brought about by any of the laws now existing, and is not indicated by anything which we perceive. This doctrine was naturally espoused with warmth by the extreme uniformitarian school, which required an unlimited duration of time for the accomplishment of such slow and quiet cycles of change as they conceived to be alone recognisable in the records of the earth's past history.

It was Lord Kelvin who, in the writings to which I have already referred, first called attention to the fundamentally erroneous nature of these conceptions. $\mathrm{He}$ pointed out that from the high internal temperature of our globe, increasing inwards as it does, and from the rate of loss of its heat, a limit may be fixed to the planet's antiquity. He showed that so far from 
there being no sign of a beginning, and no prospect of an end to the present economy, every lineament of the solar system bears witness to a gradual dissipation of energy from some definite starting-point. No very precise data were then, or indeed are now, available for computing the interval which has elapsed since that remote commencement, but he estimated that the surface of the globe could not have consolidated less than twenty millions of years ago, for the rate of increase of temperature inwards would in that case have been higher than it actually is; nor more than 400 millions of years ago, for then there would have been no sensible increase at all. He was inclined, when first dealing with the subject, to believe that from a review of all the evidence then available, some such period as roo millions of years would embrace the whole geological history of the globe.

It is not a pleasant experience to discover that a fortune which one has unconcernedly believed to be ample has somehow taken to itself wings and disappeared. When the geologist was suddenly awakened by the energetic warning of the physicist, who assured him that he had enormously overdrawn his account with past time, it was but natural under the circumstances that he should think the accountant to be mistaken, who thus returned to him dishonoured the large drafts he had made on eternity. He saw how wide were the limits of time deducible from physical considerations, how vague the data from which they had been calculated. And though he could not help admitting that a limit must be fixed beyond which his chronology could not be extended, he consoled 


\section{INTERVEN'TION OF PHYSICISTS I 85}

himself with the reflection that after all a hundred millions of years was a tolerably ample period of time, and might possibly have been quite sufficient for the transaction of all the prolonged sequence of events recorded in the crust of the earth. $\mathrm{He}$ was therefore disposed to acquiesce in the limitation thus imposed upon geological history.

But physical inquiry continued to be pushed forward with regard to the early history and the antiquity of the earth. Further consideration of the influence of tidal friction in retarding the earth's rotation, and of the sun's rate of cooling, led to sweeping reductions of the time allowable for the evolution of the planet. The geologist found himself in the plight of Lear when his bodyguard of one hundred knights was cut down. 'What need you five-and-twenty, ten, or five?' demands the inexorable physicist, as he remorselessly strikes slice after slice from his allowance of geological time. Lord Kelvin is willing, I believe, to grant us some twenty millions of years, but Professor Tait would have us content with less than ten millions.

In scientific as in other mundane questions there may often be two sides, and the truth may ultimately be found not to lie wholly with either. I frankly confess that the demands of the early geologists for an unlimited series of ages were extravagant, and even, for their own purposes, unnecessary, and that the physicist did good service in reducing them. It may also be freely admitted that the latest conclusions, from physical considerations of the extent of geological time, require that the interpretation given to the record 
of the rocks should be rigorously revised, with the view of ascertaining how far that interpretation may be capable of modification or amendment. But we must also remember that the geological record constitutes a voluminous body of evidence regarding the earth's history which cannot be ignored, and must be explained in accordance with ascertained natural laws. If the conclusions derived from the most careful study of this record cannot be reconciled with those drawn from physical considerations, it is surely not too much to ask that the latter should be also revised. It was well said by Huxley that the mathematical mill is an admirable piece of machinery, but that the value of what it yields depends upon the quality of what is put into it. That there must be some flaw in the physical argument I can, for my own part, hardly doubt, though I do not pretend to be able to say where it is to be found. Some assumption, it seems to me, has been made, or some consideration has been left out of sight, which will eventually be seen to vitiate the conclusions, and which when duly taken into account will allow time enough for any reasonable interpretation of the geological record.

In problems of this nature, where geological data capable of numerical statement are so needful, it is hardly possible to obtain trustworthy computations of time. We can only measure the rate of changes in progress now, and infer from these changes the length of time required for the completion of results achieved by the same processes in the past. There is fortunately one great cycle of movement which admits of careful investigation, and which has been made to 
furnish valuable materials for estimates of this kind. The universal degradation of the land, so notable a characteristic of the earth's surface, has been regarded as an extremely slow process. Though it goes on without ceasing, yet from century to century it seems to leave hardly any perceptible trace on the landscapes of a country. Mountains and plains, hills and valleys, appear to wear the same familiar aspect which is indicated in the oldest pages of history. This obvious slowness in one of the most important departments of geological activity, doubtless contributed in large measure to form and foster a vague belief in the vastness of the antiquity required for the evolution of the earth.

But, as geologists eventually came to perceive, the rate of degradation of the land is capable of actual measurement. The amount of material worn away from the surface of any drainage-basin and carried in the form of mud, sand, or gravel, by the main river into the sea, represents the extent to which that surface has been lowered by waste in any given period of time. But denudation and deposition must be equivalent to each other. As much material must be laid down in sedimentary accumulations as has been mechanically removed, so that in measuring the annual bulk of sediment borne into the sea by a river, we obtain a clue not only to the rate of denudation of the land, but also to the rate at which the deposition of new sedimentary formations takes place.

As might be expected, the activities involved in the lowering of the surface of the land are not everywhere equally energetic. They are naturally more vigorous 
where the rainfall is heavy, where the daily range of temperature is large, and where frosts are severe. Hence they are obviously much more effective in mountainous regions than on plains; and their results must constantly vary, not only in different basins of drainage, but even, and sometimes widely, within the same basin. Actual measurement of the proportion of sediment in river water shows that while in some cases the lowering of the surface of the land may be as much as $\frac{1}{730}$ of a foot in a year, in others it falls as low as $\frac{1}{6800}$. In other words, the rate of deposition of new sedimentary formations, over an area of seafloor equivalent to that which has yielded the sediment, may vary from one foot in 730 years to one foot in 6800 years.

If now we take these results and apply them as measures of the length of time required for the deposition of the various sedimentary masses that form the outer part of the earth's crust, we obtain some indication of the duration of geological history. On a reasonable computation these stratified masses, where most fully developed, attain a united thickness of not less than I00,000 feet. If they were all laid down at the most rapid recorded rate of denudation, they would require a period of seventy-three millions of years for their completion. If they were laid down at the slowest rate they would demand a period of not less than 680 millions.

But it may be argued that all kinds of terrestrial energy are growing feeble, that the most active denudation now in progress is much less vigorous than that of bygone ages, and hence that the stratified part of 


\section{PROOFS OF SLOW CHANGES I 89}

the earth's crust may have been put together in a much briefer space of time than modern events might lead us to suppose. Such arguments are easily adduced and look sufficiently specious, but no confirmation of them can be gathered from the rocks. On the contrary, no one can thoughtfully study the various systems of stratified formations without being impressed by the fulness of their evidence that, on the whole, the accumulation of sediment has been extremely slow. Again and again we encounter groups of strata composed of thin paper-like laminæ of the finest silt, which evidently settled down quietly and at intervals on the sea bottom. We find successive layers covered with ripple-marks and sun-cracks, and we recognise in them memorials of ancient shores where sand and mud tranquilly gathered as they do in sheltered estuaries at the present day. We can see no proof whatever, nor even any evidence which suggests, that on the whole the rate of waste and sedimentation was more rapid during Mesozoic and Palæozoic time than it is to-day. Had there been any marked difference in this rate from ancient to modern times, it would be incredible that no clear proof of it should have been recorded in the crust of the earth.

But in actual fact the testimony in favour of the slow accumulation and high antiquity of the geological record is much stronger than might be inferred from the mere thickness of the stratified formations. These sedimentary deposits have not been laid down in one unbroken sequence, but have had their continuity interrupted again and again by upheaval and depression. So fragmentary are they in some regions, that we can 
easily demonstrate the length of time represented there by still existing sedimentary strata to be vastly less than the time indicated by some of the gaps in the series.

There is yet a further and impressive body of evidence furnished by the successive races of plants and animals which have lived upon the earth and have left their remains sealed up within its rocky crust. No one now believes in the exploded doctrine that successive creations and universal destructions of organic life are chronicled in the stratified rocks. It is everywhere admitted that, from the remotest times up to the present day, there has been an onward march of development, type succeeding type in one long continuous progression. As to the rate of this evolution precise data are wanting. There is, however, the important negative argument furnished by the absence of evidence of recognisable specific variations of organic forms since man began to observe and record. We know that within human experience a few species have become extinct, but there is no conclusive proof that a single new species has come into existence, nor are appreciable variations readily apparent in forms that live in a wild state. The seeds and plants found with Egyptian mummies, and the flowers and fruits depicted on Egyptian tombs, are easily identified with the vegetation of modern Egypt. The embalmed bodies of animals found in that country show no sensible divergence from the structure or proportions of the same animals at the present day. The human races of Northern Africa and Western Asia were already as distinct when portrayed by the ancient Egyptian 


\section{ANTIQUITY OF LIVING SPECIES I9I}

artists as they are now, and they do not seem to have undergone any perceptible change since then. Thus a lapse of four or five thousand years has not been accompanied by any recognisable variation in such forms of plant and animal life as can be tendered in evidence. Absence of sensible change in these instances is, of course, no proof that considerable alteration may not have been accomplished in other forms more exposed to vicissitudes of climate and other external influences. But it furnishes at least a presumption in favour of the extremely tardy progress of organic variation.

If, however, we extend our vision beyond the narrow range of human history, and look at the remains of the plants and animals preserved in those younger formations which, though recènt when regarded as parts of the whole geological record, must be many thousands of years older than the very oldest of human monuments, we encounter the most impressive proofs of the persistence of specific forms. Shells which lived in our seas before the coming of the Ice-Age present the very same peculiarities of form, structure, and ornament which their descendants still possess. The lapse of so enormous an interval of time has not sufficed seriously to modify them. So too with the plants and the higher animals which still survive. Some forms have become extinct, but few or none which remain display any transitional gradations into new species. We must admit that such transitions have occurred, that indeed they have been in progress ever since organised existence began upon our planet, and are doubtless taking place now. But we cannot 
detect them on the way, and we feel constrained to believe that their march must be excessively slow.

There is no reason to think that the rate of organic evolution has ever seriously varied; at least no proof has been adduced of such variation. Taken in connection with the testimony of the sedimentary rocks, the inferences deducible from fossils entirely bear out the opinion that the building up of the stratified crust of the earth has been extremely gradual. If the many thousands of years which have elapsed since the IceAge have produced no appreciable modification of surviving plants and animals, how vast a period must have been required for that marvellous scheme of organic development which is chronicled in the rocks!

After careful reflection on the subject, I affirm that the geological record furnishes a mass of evidence which no arguments drawn from other departments of Nature can explain away, and which, it seems to me, cannot be satisfactorily interpreted save with an allowance of time much beyond the narrow limits which recent physical speculation would concede. ${ }^{1}$

I have reserved for final consideration a branch of the history of the earth which, while it has become, within the lifetime of the present generation, one of the most interesting and fascinating departments of geological inquiry, owed its first impulse to the farseeing intellects of Hutton and Playfair. With the penetration of genius these illustrious teachers perceived that if the broad masses of land and the great chains of mountains owe their origin to stupendous

${ }^{1}$ The problem of Geological Time was made the subject of a later address. See postea, p. 198. 
movements which from time to time have convulsed the earth, their details of contour must be mainly due to the eroding power of running water. They recognised that as the surface of the land is continually worn down, it is essentially by a process of sculpture that the physiognomy of every country has been developed, valleys being hollowed out and hills left standing, and that these inequalities in topographical detail are only varying and local accidents in the progress of the one great process of the degradation of the land.

From the broad and guiding outlines of theory thus sketched we have now advanced amid everwidening multiplicity of detail into a fuller and nobler conception of the origin of scenery. The law of evolution is written as legibly on the landscapes of the earth as on any other page of the Book of Nature. Not only do we recognise that the existing topography of the continents, instead of being primeval in origin, has gradually been developed after many precedent mutations, but we are enabled to trace these earlier revolutions in the structure of every hill and glen. Each mountain-chain is thus found to be a memorial of successive stages in geographical evolution. Within certain limits, land and sea have changed places again and again. Volcanoes have broken out and have become extinct in many countries long before the advent of man. Whole tribes of plants and animals have meanwhile come and gone, and in leaving their remains behind them as monuments at once of the slow development of organic types, and of the prolonged vicissitudes of the terrestrial surface, have furnished materials for a chronological arrangement of 
the earth's topographical features. Nor is it only from the organisms of former epochs that broad generalisations may be drawn regarding revolutions in geography. The living plants and animals of to-day have been discovered to be eloquent of ancient geographical features that have long since vanished. In their distribution they tell us that climates have changed, that islands have been disjoined from continents, that oceans once united have been divided from each other, or once separate have now been joined; that some tracts of land have disappeared, while others for prolonged periods of time have remained in isolation. The present and the past are thus linked together not merely by dead matter, but by the world of living things, into one vast system of continuous progression.

In this marvellous increase of knowledge regarding the transformations of the earth's surface, one of the most impressive features, to my mind, is the power now given to us of perceiving the many striking contrasts between the present and former aspects of topography and scenery. We seem to be endowed with a new sense. What is seen by the bodily eye-mountain, valley, or plain-serves but as a veil, beyond which, as we raise it, visions of long-lost lands and seas rise before us in a far-retreating vista. Pictures of the most diverse and opposite character are beheld, as it were, through each other, their lineaments subtly interwoven and even their most vivid contrasts subdued into one blended harmony. Like the poet, "we see, but not by sight alone'; and the 'ray of fancy' which, as a sunbeam, lightened up his landscape, is 
for us broadened and brightened by that play of the imagination which science can so vividly excite and prolong.

Admirable illustrations of this modern interpretation of scenery are supplied by the district wherein we are now assembled. On every side of us rise the most convincing proofs of the reality and potency of that ceaseless sculpture by which the elements of landscape have been carved into their present shapes. Turn where we may, our eyes rest on hills, that project above the lowland, not because they have been upheaved into these positions, but because their stubborn materials have enabled them better to withstand the degradation which has worn down the softer strata into the plains around them. Inch by inch the surface of the land has been lowered, and each hard rock successively laid bare has communicated its own characteristics of form and colour to the scenery.

If, standing on the Castle Rock, the central and oldest site in Edinburgh, we allow the bodily eye to wander over the fair landscape, and the mental vision to range through the long vista of earlier landscapes which science here reveals to us, what a strange series of pictures passes before our gaze! The busy streets of to-day seem to fade away into the mingled copsewood and forest of prehistoric time. Lakes that have long since vanished gleam through the woodlands, and a rude canoe pushing from the shore startles the red deer that had come to drink. While we look, the picture changes to a polar scene, with bushes of stunted Arctic willow and birch, among which herds of reindeer browse and the huge mammoth makes his 
home. Thick sheets of snow are draped all over the hills around, and far to the north-west the distant gleam of glaciers and snow-fields marks the line of the Highland mountains. As we muse on this strange contrast to the living world of to-day, the scene appears to grow more Arctic in aspect, until every hill is buried under one vast sheet of ice, 2,000 feet or more in thickness, which fills up the whole midland valley of Scotland and creeps slowly eastward into the basin of the North Sea. Here the curtain drops upon our moving pageant, for in the geological record of this part of the country an enormous gap occurs before the coming of the Ice-Age.

When once more the spectacle resumes its movement the scene is found to have utterly changed. The familiar hills and valleys of the Lothians have disappeared. Dense jungles of a strange vegetationtall reeds, club-mosses, and tree-ferns-spread over the steaming swamps that stretch for leagues in all directions. Broad lagoons and open seas are dotted with little volcanic cones which throw out their streams of lava and showers of ashes. Beyond these, dimmer in outline and older in date, we descry a wide lake or inland sea, covering the whole midland valley and marked with long lines of active volcanoes, some of them several thousand feet in height. And still further and fainter over the same region, we may catch a glimpse of that still earlier expanse of sea which in Silurian times overspread most of Britain. But beyond this scene our vision fails. We have reached the limit across which no geological evidence exists to lead the imagination into the primeval darkness beyond. 


\section{SCENERY OF EDINBURGH}

Such in briefest outline is the succession of mental pictures which modern science enables us to frame out of the landscapes around Edinburgh. They may be taken as illustrations of what may be drawn, and sometimes with even greater fulness and vividness, from any district in these islands. But I cite them especially because of their local interest in connection with the present meeting of the Association, and because the rocks that yield them gave inspiration to those great masters whose claims on our recollection, not least for their explanation of the origin of scenery, I have tried to recount this evening. But I am further impelled to dwell on these scenes from an overmastering personal feeling to which I trust I may be permitted to give expression. It was these green hills and grey crags that gave me in boyhood the impulse that has furnished the work and joy of my life. To them, amid changes of scene and surroundings, my heart ever fondly turns, and here I desire gratefully to acknowledge that it is to their influence that I am indebted for any claim I may possess to stand in the proud position in which your choice has placed me. 


\section{VI \\ Geological Time ${ }^{1}$}

Among the many questions of great theoretical importance which have engaged the attention of geologists, none has in late years awakened more interest or aroused livelier controversy than that which deals with Time as an element in geological history. The various schools which have successively arisen-Cataclysmal, Uniformitarian, and Evolutionist-have had each its own views as to the duration of their chronology, as well as to the operations of terrestrial energy. But though holding different opinions, they did not make these differences matter of special controversy among themselves. About thirty years ago, however, they were startled by a bold irruption into their camp from the side of physics. They were then called on to reform their ways, which were declared to be flatly opposed to the teachings of natural philosophy. Since that period the discussion then started regarding the age of the Earth and the value of geological time has

${ }^{1}$ Presidential Address to the Geological Section of the British Association for the Advancement of Science at the Dover Meeting 1899. 
continued with varying animation. Evidence of the most multifarious kind has been brought forward, and arguments of widely different degrees of validity have been pressed into service both by geologists and palæontologists on one side, and by physicists on the other. For the last year or two there has been a pause in the controversy, though no general agreement has been arrived at in regard to the matters in dispute. The present interval of comparative quietude seems favourable for a dispassionate review of the debate. I propose, therefore, to take, as perhaps a not inappropriate subject on which to address geologists upon a somewhat international occasion like this present meeting of the British Association at Dover, the question of Geological Time. In offering a brief history of the discussion, I gladly avail myself of the opportunity of enforcing one of the lessons which the controversy has impressed upon my own mind, and to point a moral which, as it seems to me, we geologists may take home to ourselves from a consideration of the whole question. There is, I think, a practical outcome which may be made to issue from the dispute in a combination of sympathy and co-operation among geologists all over the world. A lasting service will be rendered to our science if by well-concerted effort we can place geological dynamics and geological chronology on a broader and firmer basis of actual experiment and measurement than has yet been laid.

To understand aright the origin and progress of the dispute regarding the value of time in geological speculation, we must take note of the attitude maintained towards this subject by some of the early fathers of 
the science. Among these pioneers none has left his mark more deeply graven on the foundations of modern geology than James Hutton. To him, more than to any other writer of his day, do we owe the doctrine of the high antiquity of our globe. No one before him had ever seen so clearly the abundant and impressive proofs of this remote antiquity recorded in the rocks of the earth's crust. In these rocks he traced the operation of the same slow and quiet processes which he observed to be at work at present in gradually transforming the face of the existing continents. When he stood face to face with the proofs of decay among the mountains, there seems to have arisen uppermost in his mind the thought of the immense succession of ages which these proofs revealed to him. His observant eye enabled him to see 'the operations of the surface wasting the solid body of the globe, and to read the unmeasurable course of time that must have flowed during those amazing operations, which the vulgar do not see, and which the learned seem to see without wonder.' ${ }^{\prime}$ In contemplating the stupendous results achieved by such apparently feeble forces, Hutton felt that one great objection he had to contend with in the reception of his theory, even by the scientific men of his day, lay in the inability or unwillingness of the human mind to admit such large demands as he made on the past. 'What more can we require?' he asks in summing up his conclusions; and he answers the question in these memorable words: "What more can we require? Nothing but time. It is not any part of the process 
that will be disputed; but after allowing all the parts, the whole will be denied; and for what?-only because we are not disposed to allow that quantity of time which the ablution of so much wasted mountain might require.' ${ }^{1}$

Far as Hutton could follow the succession of events registered in the rocky crust of the globe, he found himself baffled by the closing in around him of that dark abysm of time into which neither eye nor imagination seemed able to penetrate. He well knew that, behind and beyond the ages recorded in the oldest of the primitive rocks, there must have stretched a vast earlier time, of which no record met his view. $\mathrm{He}$ did not attempt to speculate beyond the limits of his evidence. 'I do not pretend,' he said, ' to describe the beginning of things; I take things such as I find them at present, and from these I reason with regard to that which must have been.' 2 In vain did he look, even among the oldest formations, for any sign of the infancy of the planet. He could only detect a repeated series of similar revolutions, the oldest of which was assuredly not the first in the terrestrial history, and he concluded, as 'the result of this physical inquiry, that we find no vestige of a beginning, no prospect of an end.' 3

This conclusion from strictly geological evidence has been impugned from the side of physics, and, as further developed by Playfair, has been declared to be contradicted by the principles of natural philosophy. But if it be considered on the basis of the evidence on which
${ }^{1}$ Op. cit., vol. i. p. 173 , note.
2 Op. cit., vol. ii. p. 329.
3 Op. cit., vol. i. p. 200. 
it was originally propounded, it was absolutely true in Hutton's time and remains true to-day. That able reasoner never claimed that the earth has existed from all eternity, or that it will go on existing for ever. He admitted that it must have had a beginning, but he had been unable to find any vestige of that beginning in the structure of the planet itself. And notwithstanding all the multiplied researches of the century that has passed since the immortal Theory of the Earth was published, no relic of the first condition of our earth has been found. We have speculated much, indeed, on the subject, and our friends the physicists have speculated still more. Some of the speculations do not seem to me more philosophical than many of those of the older cosmogonists. As far as reliable evidence can be drawn from the rocks of the globe itself, we do not seem to be nearer the discovery of the beginning than Hutton was. The most ancient rocks that can be reached are demonstrably not the first-formed of all. They were preceded by others which we know must have existed, though no vestige of them may be accessible.

It may be further asserted that, while it was Hutton who first impressed upon modern geology the conviction that for the adequate comprehension of the past history of the earth vast periods of time must be admitted to have elapsed, our debt of obligation to him is increased by the genius with which he linked the passage of these vast periods with the present economy of nature. He first realised the influence of time as a factor in geological dynamics, and first taught the efficacy of the quiet and unobtrusive forces of nature. 
His predecessors and contemporaries were never tired of invoking the more vigorous manifestations of terrestrial energy. They saw in the composition of the land and in the structure of mountains and valleys memorials of numberless convulsions and cataclysms. In Hutton's philosophy, however, ' it is the little causes, long continued, which are considered as bringing about the greatest changes of the earth.' ${ }^{1}$

And yet, unlike many of those who derived their inspiration from his teaching, but pushed his tenets to extremes which he doubtless never anticipated, he did not look upon time as a kind of scientific fetich, the invocation of which would endow with efficacy even the most trifling phenomena. As if he had foreseen the use that might be made of his doctrine, he uttered this remarkable warning: "With regard to the effect of time, though the continuance of time may do much in those operations which are extremely slow, where no change, to our observation, had appeared to take place, yet, where it is not in the nature of things to produce the change in question, the unlimited course of time would be no more effectual than the moment by which we measure events in our observations.' ${ }^{2}$

We thus see that in the philosophy of Hutton, out of which so much of modern geology has been developed, the vastness of the antiquity of the globe was deduced from the structure of the terrestrial crust and the slow rate of action of the forces by which the surface of the crust is observed to be modified. But no

\footnotetext{
${ }^{1}$ Theory of the Earth, vol. ii. p. 205.

${ }^{2}$ Op. cit., vol. i. p. 44.
} 
attempt was made by him to measure that antiquity by any of the chronological standards of human contrivance. He was content to realise for himself and to impress upon others that the history of the earth could not be understood, save by the admission that it occupied prolonged though indeterminate ages in its accomplishment. And assuredly no part of his teaching has been more amply sustained by the subsequent progress of research.

Playfair, from whose admirable Illustrations of the Huttonian Theory most geologists have derived all that they know directly of that theory, went a little further than his friend and master in dealing with the age of the earth. Not restricting himself, as Hutton did, to the testimony of the rocks, which showed neither vestige of a beginning nor prospect of an end, he called in the evidence of the cosmos outside the limits of our planet, and declared that in the firmament also no mark could be discovered of the commencement or termination of the present order, no symptom of infancy or old age, nor any sign by which the future or past duration of the universe might be estimated. ${ }^{1} \mathrm{He}$ thus advanced beyond the strictly geological basis of reasoning, and committed himself to statements which, like some made also by Hutton, seem to have been suggested by certain deductions of the French mathematicians of his day regarding the stability of the planetary motions. His statements have been disproved by modern physics; distinct evidence, both from the earth and the cosmos, has been brought forward of progress from a beginning which can be

${ }^{1}$ Illustrations of the Huttonian Theory, \$ I I8. 
conceived, through successive stages to an end which can be foreseen. But the disproof leaves Hutton's doctrine about the vastness of geological time exactly where it was. Surely it was no abuse of language to speak of periods as being vast, which can only be expressed in millions of years.

It is easy to understand how the Uniformitarian school, which sprang from the teaching of Hutton and Playfair, came to believe that the whole of eternity was at the disposal of geologists. In popular estimation, as the ancient science of astronomy was that of infinite distance, so the modern study of geology was the science of infinite time. It must be frankly conceded that geologists, believing themselves unfettered by any limits to their chronology, made ample use of their imagined liberty. Many of them, following the lead of Lyell, to whose writings in other respects modern geology owes so deep a debt of gratitude, became utterly reckless in their demands for time, demands which even the requirements of their own science, if they had adequately realised them, did not warrant. The older geologists had not attempted to express their vast periods in terms of years. The indefiniteness of their language fitly denoted the absence of any ascertainable limits to the successive ages with which they had to deal. And until some evidence should be discovered whereby these limits might be fixed and measured by human standards, no reproach could justly be brought against the geological terminology. It was far more philosophical to be content, in the meanwhile, with indeterminate expressions, than from data of the weakest or most speculative kind to 
attempt to measure geological periods by a chronology of years or centuries.

In the year I 862 a wholly new light was thrown on the question of the age of our globe and the duration of geological time by the remarkable paper on the Secular Cooling of the Earth communicated by Lord Kelvin (then Sir William Thomson) to the Royal Society of Edinburgh. ${ }^{1}$ In this memoir he first developed his now well-known argument from the observed rate of increase of temperature downwards from the surface of the land. He astonished geologists by announcing to them that some definite limits to the age of our planet might be ascertained, and by declaring his belief that this age must be more than 20 millions, but less than 400 millions of years.

Nearly four years later he emphasised his dissent from what he considered to be the current geological opinions of the day by repeating the same argument in a more pointedly antagonistic form in a paper of only a few sentences, entitled, 'The Doctrine of Uniformity in Geology briefly refuted.' 2

Again, after a further lapse of about two years, when, as President of the Geological Society of Glasgow, it became his duty to give an address, he returned to the same topic and arraigned more boldly and explicitly than ever the geology of the time. He then declared that 'a great reform in geological speculation seems now to have become necessary,' and he went so far as to affirm that ' it is quite certain that a great mistake has been made-that British popular geology at the

1 Trans. Roy. Soc. Edin., vol. xxiii. (1 862 ).

2 Proc. Roy. Soc. Edin., vol. v. p. 512 (Dec. 18, 1865). 
present time is in direct opposition to the principles of natural philosophy.' ${ }^{\prime}$ In pressing once more the original argument derived from the downward increase of terrestrial temperature, he now reinforced it by two further arguments, the one based on the retardation of the earth's angular velocity by tidal friction, the other on the limitation of the age of the sun.

These three lines of attack remain still those along which the assault from physics is delivered against the strongholds of geology. Lord Kelvin has repeatedly returned to the charge since I868, his latest contribution to the controversy having been pronounced two years ago. ${ }^{2}$ While his physical arguments remain the same, the limits of time which he deduces from them have been successively diminished. The original maximum of 400 millions of years has now been restricted by him to not much more than 20 millions, while Professor Tait grudgingly allows something less than Io millions. ${ }^{3}$

Soon after the appearance of Lord Kelvin's indictment of modern geology in r868, the defence of the science was taken up by Huxley, who happened at the time to be President of the Geological Society of London. In his own inimitably brilliant way, half seriously, half playfully, this doughty combatant, with evident relish, tossed the physical arguments to and fro in the eyes of his geological brethren, as a barrister may flourish his brief before a sympathetic jury. $\mathrm{He}$

${ }^{1}$ Trans. Geol. Soc. Glasgow, vol. iii. (February, 1868), pp. I, 16.

2 'The Age of the Earth,' being the Annual Address to the Victoria Institute, June 2, I897. Phil. Mag., January, 1899, p. 66.

${ }^{3}$ Recent Advances in Physical Science, p. 174. 
was willing to admit that 'the rapidity of rotation of the earth may be diminishing, that the sun may be waxing dim, or that the earth itself may be cooling.' But he went on to add his suspicion that ' most of us are Gallios, who care for none of these things, being of opinion that, true or fictitious, they have made no practical difference to the earth, during the period of which a record is preserved in stratified deposits.' 1

For the indifference which their advocate thus professed on their behalf most geologists believed that they had ample justification. The limits within which the physicist would circumscribe the earth's history were so vague yet so vast, that whether the time allowed were 400 millions or 100 millions of years did not seem to them greatly to matter. After all, it was not the time that chiefly interested them, but the grand succession of events which the time had witnessed. That succession had been established on observations so abundant and so precise that it could withstand attack from any quarter, and it had taken as firm and lasting a place among the solid achievements of science as could be claimed for any physical speculations whatsoever. Whether the time required for the transaction of this marvellous earthhistory was some millions of years more or some millions of years less did not seem to the geologists to be a question on which their science stood in antagonism with the principles of natural philosophy, but one which the natural philosophers might be left to settle at their own good pleasure.

${ }^{1}$ Presidential Address. Quart. Journ. Geol. Soc., 1869. 


\section{LORD KELVIIN'S VIEWS}

For myself, I may be permitted here to say that I have never shared this feeling of indifference and unconcern. As far back as the year I 868, only a month after Lord Kelvin's first presentation of his threefold argument in favour of limiting the age of the earth, I gave in my adhesion to the propriety of restricting the geological demands for time. I then showed that even the phenomena of denudation, which, from the time of Hutton downwards, had been most constantly and confidently appealed to in support of the inconceivably vast antiquity of our globe, might be accounted for, at the present rate of action, within such a period as 100 millions of years. ${ }^{1}$ To my mind it has always seemed that whatever tends to give more precision to the chronology of the geologist, and helps him to a clearer conception of the antiquity with which he has to deal, ought to be welcomed by him as a valuable assistance in his inquiries. And I feel sure that this view of the matter has now become general among those engaged in geological research. Frank recognition is made of the influence which Lord Kelvin's persistent attacks have had upon our science. Geologists have been led by his criticisms to revise their chronology. They gratefully acknowledge that to him they owe the introduction of important new lines of investigation, which link the solution of the problems of geology with those of physics. They realise how much he has done to dissipate the former vague conceptions as to the duration of geological

${ }^{1}$ Trans. Geol. Soc. Glasgow, vol. iii. (March 26, 1868), p. 189. Sir W. Thomson acknowledged my adhesion in his reply to Huxley's criticism. Op. cit., p. 221 . 
history, and even when they emphatically dissent from the greatly restricted bounds within which he would now limit that history, and when they declare their inability to perceive that any further reform of their speculations in this subject is needful, or that their science has placed herself in opposition to the principles of physics, they none the less pay their sincere homage to one who has thrown over geology, as over so many other departments of natural knowledge, the clear light of a penetrating and original genius.

When Lord Kelvin first developed his strictures on modern geology he expressed his opposition in the most uncompromising language. In the short paper to which reference has already been made he announced, without hesitation or palliation, that he 'briefly refuted' the doctrine of Uniformitarianism which had been espoused and illustrated by Lyell and a long list of the ablest geologists of the day. The severity of his judgment of British geology was not more marked than was his unqualified reliance on his own methods and results. This confident assurance of a distinguished physicist, together with a formidable array of mathematical formulæ, produced its effect on some geologists and palæontologists who were not Gallios. Thus, even after Huxley's brilliant defence, Darwin could not conceal the deep impression which Lord Kelvin's arguments had made on his mind. In one letter he wrote that the proposed limitation of geological time was one of his 'sorest troubles.' In another, he pronounced the physicist himself to be 'an odious spectre.' 1

${ }^{1}$ Darwin's Life and Letters, vol. iii. pp. I1 5, 146. 
The same self-confidence of assertion on the part of some, at least, of the disputants on the physical side has continued all through the controversy. Yet when we examine the three great physical arguments in themselves, we find them to rest on assumptions which, though certified as 'probable' or 'very sure,' are nevertheless admittedly assumptions. The conclusions to which these assumptions lead must depend for their validity on the degree of approximation to the truth in the premises which are postulated.

Now it is interesting to observe that neither the assumptions nor the conclusions drawn from them have commanded universal assent even among physicists themselves. If they were as self-evident as they have been claimed to be, they should at least receive the loyal support of all those whose function it is to pursue and extend the applications of physics. It will be remembered, however, that thirteen years ago Professor George Darwin, who has so often shown his inherited sympathy in geological investigation, devoted his presidential address before the Mathematical Section of this Association to a review of the three famous physical arguments respecting the age of the earth. He summed up his judgment of them in the following words: 'In considering these three arguments I have adduced some reasons against the validity of the first [tidal friction]; and have endeavoured to show that there are elements of uncertainty surrounding the second [secular cooling of the earth]; nevertheless they undoubtedly constitute a contribution of the first importance to physical geology. Whilst, then, we may protest against the precision with which 
Professor Tait seeks to deduce results from them, we are fully justified in following Sir William Thomson, who says that "the existing state of things on the earth, life on the earth-all geological history showing continuity of life, must be limited within some such period of past time as $100,000,000$ years." ' 1

More recently Professor Perry has entered the lists, from the physical side, to challenge the validity of the conclusions so confidently put forward in limitation of the age of the earth. He has boldly impugned each of the three physical arguments. That which is based on tidal retardation, following Mr. Maxwell Close and Professor Darwin, he dismisses as fallacious. In regard to the argument from the secular cooling of the earth, he contends that it is perfectly allowable to assume a much higher conductivity for the interior of the globe, and that this assumption would vastly increase our estimate of the age of the planet. As to the conclusions drawn from the history of the sun, he maintains that, on the one hand, the sun may have been repeatedly fed by infalling meteorites, and that on the other hand, the earth, during former ages, may have had its heat retained by a dense atmospheric envelope. He thinks that 'almost anything is possible as to the present internal state of the earth,' and he concludes in these words: 'To sum up, we can find no published record of any lower maximum age of life on the earth, as calculated by physicists, than 400 millions of years. From the three physical arguments, Lord Kelvin's higher limits are I,000,

${ }^{1}$ Rep. Brit. Assoc., 1886, p. 517. 
400 , and 500 million years. I have shown that we have reasons for believing that the age, from all these, may be very considerably underestimated. It is to be observed that if we exclude everything but the arguments from mere physics, the probable age of life on the earth is much less than any of the above estimates; but if the palæontologists have good reasons for demanding much greater times, I see nothing from the physicist's point of view which denies them four times the greatest of these estimates.' 1

This remarkable admission from a recognised authority on the physical side re-echoes and emphasises the warning pronounced by Professor Darwin in the address already quoted-' at present our knowledge of a definite limit to geological time has so little precision that we should do wrong to summarily reject any theories which appear to demand longer periods of time than those which now appear allowable.' 2

This 'wrong,' which Professor Darwin so seriously deprecated, has been committed not once, but again and again, in the history of this discussion. Lord Kelvin has never taken any notice of the strong body of evidence adduced by geologists and palæontologists in favour of a much longer antiquity than he is now disposed to allow for the age of the earth. His own three physical arguments have been successively re-stated, with such corrections and modifications as he has found to be necessary, and no doubt

\footnotetext{
${ }^{1}$ Nature, vol. li. p. 585 , April 18, 1895 .

${ }^{2}$ Rep. Brit. Assoc., I886, p. 518.
} 
further alterations are in store for them. ${ }^{1} \mathrm{He}$ has cut off slice after slice from the allowance of time which at first he was prepared to grant for the evolution of geological history, his latest pronouncement being that 'it was more than twenty and less than forty million years, and probably much nearer

${ }^{1}$ October 1904. Since this Address was given the subject of radioactivity has assumed high importance in reference to questions connected with the evolution of the cosmos. Thus Prof. George Darwin, in view of the newly discovered properties of radium, has stated that he sees 'no reason for doubting the possibility of augmenting the estimates of solar heat, as derived from the theory of gravitation, by some such factor as ten or twenty' (Nature, 24 th Sept., 1903). The same opinion is shared by Prof. Joly, who points out that the establishment of the observed gradient of temperature from the earth's surface inward 'may have been deferred indefinitely during the exhaustion of stores of radium and similar bodies at greater or shallower depths' (Nature, Ist Oct., 1903). More recently Prof. Rutherford, who has taken so leading a part in the discussion of radio-activity, has made the following statement: 'I think we may conclude that the present rate of loss of heat of the earth might have continued unchanged for long periods of time in consequence of the supply of heat from radio-active matter in the earth. It thus seems probable that the earth may have remained for very long intervals of time at a temperature not very different from that observed to-day, and that in consequence the time during which the earth has been at a temperature capable of supporting the presence of animal and vegetable life may be very much longer than the estimate made by Lord Kelvin from other data' (Radio-activity, Cambridge, 1904, p. 346). Thus two of the three physical arguments are impugned on new grounds, and the forecast of Prof. Darwin is shown to have been reasonable when in 1886 he said: 'Although speculations as to the future course of science are usually of little avail, yet it seems as likely that meteorology and geology will pass the word of command to cosmical physics as the converse.' 


\section{PROGRESS OF CONTROVERSY 215}

twenty than forty.' ${ }^{1}$ But in none of his papers is there an admission that geology and palæontology, though they have again and again raised their voices in protest, have anything to say in the matter that is worthy of consideration.

It is difficult satisfactorily to carry on a discussion in which your opponent entirely ignores your arguments, while you have given the fullest attention to his. In the present instance, geologists have most carefully listened to all that has been brought forward from the physical side. Impressed by the force of the physical reasoning, they no longer believe that they can make any demands they may please on past time. They have been willing to accept Lord Kelvin's original estimate of 100 millions of years as the period within which the history of life upon the planet must be comprised; while some of them have even sought in various ways to reduce that sum nearer to his lower limit. Yet there is undoubtedly a prevalent misgiving, whether in thus seeking to reconcile their requirements with the demands of the physicist they are not tying themselves down within limits of time which on any theory of evolution would have been insufficient for the development of the animal and vegetable kingdoms.

It is unnecessary to recapitulate before this Section of the British Association, even in briefest outline, the reasoning of geologists and palæontologists which leads them to conclude that the history recorded in the crust of the earth must have required for its transaction a much vaster period of time than that

${ }^{1}$ The Age of the Earth, Presidential Address to the Victoria Institute for 1897, p. 10; also in Phil. Mag. January 1899. 
to which the physicists would restrict it. ${ }^{1}$ Let me merely remark that the reasoning is essentially based on observations of the present rate of geological and biological changes upon the earth's surface. It is not, of course, maintained that this rate has never varied in the past. But it is the only rate with which we are familiar, which we can watch and in some degree measure, and which, therefore, we can take as a guide towards the comprehension and interpretation of the past history of our planet.

It may be, and has often been, said that the present scale of geological and biological processes cannot be accepted as a reliable measure for the past. Starting from the postulate, which no one will dispute, that the total sum of terrestrial energy was once greater than it is now and has been steadily declining, the physicists have boldly asserted that all kinds of geological action must have been more vigorous and rapid during bygone ages than they are to-day; that volcanoes were more gigantic, earthquakes more frequent and destructive, mountain-upthrows more stupendous, tides and waves more powerful, and commotions of the atmosphere more violent, with more ruinous tempests and heavier rainfall. Assertions of this kind are temptingly plausible and are easily made. But it is not enough that they should be made; they ought to be supported by some kind of evidence to

1 The geological arguments are briefly given in my Presidential Address to the British Association at the Edinburgh Meeting of 1892 (ante p. 182). The biological arguments were well stated, and in some detail, by Professor Poulton in his Address to the Zoological Section of the Association at the Liverpool Meeting of 1896. 
show that they are founded on actual fact and not on mere theoretical possibility. Such evidence, if it existed, could surely be produced. The chronicle of the earth's history, from a very early period down to the present time, has been legibly written within the sedimentary formations of the terrestrial crust. Let the appeal be made to that register. Does it lend any support to the affirmation that the geological processes are now feebler and slower than they used to be? If it does, the physicists, we might suppose, would gladly bring forward its evidence as irrefragable confirmation of the soundness of their contention. But the geologists have found no such confirmation. On the contrary, they have been unable to discover any indication that the rate of geological causation has ever, on the whole, greatly varied during the time which has elapsed since the deposition of the oldest stratified rocks. They do not assert that there has been no variation, that there have been no periods of greater activity, both hypogene and epigene. But they maintain that the demonstration of the existence of such periods has yet to be made. They most confidently affirm that whatever may have happened in the earliest ages, throughout the whole vast succession of sedimentary strata nothing has yet been detected which necessarily demands that more violent and rapid action which the physicists suppose to have been the order of nature during the past.

So far as the potent effects of prolonged denudation permit us to judge, the latest mountain-upheavals were at least as stupendous as any of older date whereof the basal relics can yet be detected. They seem, 
indeed, to have been still more gigantic than these. It may be doubted, for example, whether among the vestiges that remain of Mesozoic or Palæozoic mountain-chains, any instance can be found so colossal as those of Tertiary times, such as the Alps. No volcanic eruptions of the older geological periods can compare in extent or volume with those of Tertiary and recent date. The plication and dislocation of the terrestrial crust are proportionately as conspicuously displayed among the younger as among the older formations, though the latter, from their greater antiquity, have suffered during a longer time from the renewed disturbances of successive periods.

As regards evidence of greater violence in the surrounding envelopes of atmosphere and ocean, we seek for it in vain among the stratified rocks. One of the very oldest formations in Europe, the Torridon Sandstone of North-West Scotland, presents us with a picture of long-continued sedimentation, such as may be seen in progress now round the shores of many a mountain-girdled lake. In that venerable deposit, the enclosed pebbles are not mere angular blocks and chips, swept by a sudden flood or destructive tide from off the surface of the land, and huddled together in confused heaps over the floor of the sea. They have been rounded and polished by the quiet operation of running water, as stones are rounded and polished now in the channels of brooks or on the shores of lake and sea. They have been laid gently down above each other, layer over layer, with fine sand sifted in between them, and this deposition has taken place along shores which, though the waters 
that washed them have long since disappeared, can still be followed for mile after mile across the mountains and glens of the North-West Highlands. So tranquil were these waters that their gentle currents and oscillations sufficed to ripple the sandy floor, to arrange the sediment in laminæ of current-bedding, and to separate the grains of sand according to their relative densities. We may even now trace the results of these operations in thin darker layers and streaks of magnetic iron, zircon, and other heavy minerals, which have been sorted out from the lighter quartzgrains, as layers of iron-sand may be seen sifted together by the tide along the upper margins of many of our sandy beaches at the present day.

In the same ancient formation there occur also various intercalations of fine muddy sediment, so regular in their thin alternations, and so like those of younger formations, that we cannot but hope and expect that they may eventually yield remains of organisms which, if found, would be the earliest traces of life in Europe.

It is thus abundantly manifest that even in the most ancient of the sedimentary registers of the earth's history, not only is there no evidence of colossal floods, tides and denudation, but there is incontrovertible proof of continuous orderly deposition, such as may be witnessed to-day in any quarter of the globe. The same tale, with endless additional details, is told all through the stratified formations, down to those which are in the course of accumulation at the present day.

Not less important than the stratigraphical is the 
palæontological evidence in favour of the general quietude of the geological processes in the past. The conclusions drawn from the nature and arrangement of the sediments are corroborated and much extended by the structure and manner of entombment of the enclosed organic remains. From the time of the very earliest fossiliferous formations there is nothing to show that either plants or animals have had to contend with physical conditions of environment different, on the whole, from those in which their successors now live. The oldest trees, so far as regards their outer form and internal structure, betoken an atmosphere neither more tempestuous nor obviously more impure than that of to-day. The earliest corals, sponges, crustaceans, mollusks, and arachnids were not more stoutly constructed than those of later times, and they are found grouped together among the rocks as they lived and died, with no apparent indication that any violent commotion of the elements tried their strength when living or swept away their remains when dead.

But, undoubtedly, most impressive of all the palæontological data is the testimony borne by the grand succession of organic remains among the stratified rocks as to the vast duration of time required for their evolution. Professor Poulton has treated this branch of the subject with great fulness and ability (p. 2I6). We do not know the present average rates of organic variation, but all the available evidence goes to indicate their extreme slowness. They may conceivably have been more rapid in the past, or they may have been liable to fluctuations according to vicissitudes of 
environment. ${ }^{1}$ But those who assert that the rate of biological evolution ever differed materially from what it may now be inferred to be, ought surely to bring forward something more than mere assertion in their support. In the meantime, the most philosophical course is undoubtedly followed by those biologists who in this matter rest their belief on their own experience among recent and fossil organisms.

So cogent do these geological and palæontological arguments appear, to those at least who have taken the trouble to master them, that they are worthy of being employed, not in defence merely, but in attack. It seems to me that they may be used with effect in assailing the stronghold of speculation and assumption in which our physical friends have ensconced themselves and from which, with their feet, as they believe, planted well within the interior of the globe and their heads in the heart of the sun, they view with complete unconcern the efforts made by those who endeavour to gather the truth from the surface and crust of the earth. That portion of the records of terrestrial history which lies open to our investigation has been diligently studied in all parts of the world. A vast body of facts has been gathered together from this extended and combined research. The chronicle registered in the earth's crust, though not complete,

${ }^{1}$ See an interesting and suggestive paper by Professor Le Conte on 'Critical Periods in the History of the Earth,' Bull. Dept. Geology, University of California, vol. i. (1895), p. 313 ; also one by Professor Chamberlin on 'The Ulterior Basis of Time-divisions and the Classification of Geological History,' Journal of Geology, vol. vi. (1 898), p. 449 . 
is legible and consistent. From the latest to the earliest of its chapters the story is capable of clear and harmonious interpretation by a comparison of its pages with the present condition of things. We know infinitely more of the history of this earth than we do of the history of the sun. Are we then to be told that this knowledge so patiently accumulated from innumerable observations and so laboriously co-ordinated and classified, is to be held of none account in comparison with the conclusions of physical science in regard to the history of the central luminary of our system? These conclusions are founded on assumptions which may or may not correspond with the truth. They have already undergone revision, and they may be still further modified as our slender knowledge of the sun, and of the details of its history, is increased by future investigation. In the meantime, we decline to accept them as a final pronouncement of science on the subject. We place over against them the evidence of geology and palæontology, and affirm that unless the deductions we draw from that evidence can be disproved, we are entitled to maintain them as entirely borne out by the testimony of the rocks.

Until, therefore, it can be shown that geologists and palæontologists have misinterpreted their records, they are surely well within their logical rights in claiming as much time for the history of this earth as the vast body of evidence accumulated by them demands. So far as I have been able to form an opinion, one hundred millions of years would suffice for that portion of the history which is registered in the stratified rocks of the crust. But if the palæontologists find such 
a period too narrow for their requirements, I can see no reason on the geological side why they should not be at liberty to enlarge it as far as they may find to be needful for the evolution of organised existence on the globe. As I have already remarked, it is not the length of time which interests us so much as the determination of the relative chronology of the events which were transacted within that time. As to the general succession of these events, there can be no dispute. We have traced its stages from the bottom of the oldest rocks up to the surface of the present continents and the floor of the present seas. We know that these stages have followed each other in orderly advance, and that geological time, whatever limits may be assigned to it, has sufficed for the passage of the long stately procession.

We may, therefore, well leave the dispute about the age of the earth to the decision of the future. In so doing, however, I should be glad if we could carry away from it something of greater service to science than the consciousness of having striven our best in a barren controversy, wherein concession has all to be on one side and the selection of arguments entirely on the other. During these years of prolonged debate I have often been painfully conscious that in this subject, as in so many others throughout the geological domain, the want of accurate numerical data is a serious hindrance to the progress of our science. Heartily do I acknowledge that much has been done in the way of measurement and experiment for the purpose of providing a foundation for estimates and deductions. But infinitely more remains to be accomplished. The field of investi- 
gation is almost boundless, for there is hardly a department of geological dynamics over which it does not extend. The range of experimental geology must be widely enlarged, until every process susceptible of illustration or measurement by artificial means has been investigated. Field-observation needs to be supplemented where possible by instrumental determination, so as to be made more precise and accurate, and more capable of furnishing reliable numerical statistics for practical as well as theoretical deductions.

The subject is too vast for adequate treatment here. But let me illustrate my meaning by selecting a few instances where the adoption of these more rigid methods of inquiry might powerfully assist us in dealing with the rates of geological processes and the value of geological time. Take, for example, the wide range of lines of investigation embraced under the head of Denudation. So voluminous a series of observations has been made in this subject, and so ample is the literature devoted to it, that no department of geology, it might be thought, has been more abundantly and successfully explored. Yet if we look through the pile of memoirs, articles and books, we cannot but be struck with the predominant vagueness of their statements, and with the general absence of such numerical data determined by accurate, systematic, and prolonged measurement as would alone furnish a satisfactory basis for computations of the rate at which denudation takes place. Some instrumental observations of the greatest value have indeed been made, but, for the most part, observations of this kind have been too meagre and desultory. 
A little consideration will show that in all branches of the investigation of denudation opportunities present themselves on every side of testing, by accurate instrumental observation and measurement, the rate at which some of the most univeral processes in the geological mechanism of our globe are carried on.

It has long been a commonplace of geology that the amount of the material removed in suspension and solution by Rivers furnishes a clue to the rate of denudation of the regions drained by the rivers. But how unequal in value, and generally how insufficient in precision, are the observations on this topic! A few rivers have been more or less systematically examined, some widely varying results have been obtained from the observations, and while enough has been gained to show the interest and importance of the method of research, no adequate supply of materials has been gathered for the purposes of wide, accurate deduction and generalisation. What we need is a carefully organised series of observations carried out on a uniform plan, over a sufficient number of years, not for one river only, but for all the important rivers of a country, and indeed for all the greater rivers of each continent. We ought to know as accurately as possible the extent of the drainage-area of each river, the relations of riverdischarge to rainfall and to other meteorological as well as topographical conditions; the variation in the proportions of mechanical and chemical impurities in the river-water according to geological formations, form of the ground, season of the year and climate. The whole geological régime of each river should be thoroughly studied. The admirable report of Messrs. Humphreys 
and Abbot on the "Physics and Hydraulics of the Mississippi,' published in I861, might well serve as a model for imitation, though these observers necessarily occupied themselves with some questions which are not specially geological, and did not enter into others on which, as geologists, we should now gladly have further information.

Again, the action of Glaciers has still less been subjected to prolonged and systematic observation. The few data already obtained are so vague that we may be said to be still entirely ignorant of the rate at which glaciers are wearing down their channels and contributing to the denudation of the land. The whole of this inquiry is eminently suitable for combined research. Each stream or glacier, or each well-marked section of one, might become the special inquiry of a single observer, who would soon develop a paternal interest in his valley and vie with his colleagues of other valleys in the fulness and accuracy of his records.

Nor is our information respecting the operations of the Sea much more precise. Even in an island like Great Britain, where the waves and tides effect so much change within the space of a human life-time, the estimates of the rate of advance or retreat of the shore-line are based for the most part on no accurate determinations. It is satisfactory to be able to announce that the Council of this Association has formed a Committee for the purpose of obtaining full and precise information regarding alterations of our coasts, and that, with the sanction of the Lords of the Admiralty, the co-operation of the Coast-guard throughout the three kingdoms has been secured. We may 
therefore hope to be eventually in possession of trustworthy statistics on this interesting subject. ${ }^{1}$

The Denudation of the Surface of the Land by the combined agency of the subaërial forces of decay is a problem which has been much studied, but in regard to whose varying rates of advance not much has been definitely ascertained. The meteorological conditions under which it takes place differ materially according to latitude and climate, and doubtless its progress is equally variable. An obvious and useful source of information in regard to atmospheric denudation is to be found in the decay of the material of buildings of which the time of erection is known, and in dated tombstones. Twenty years ago I called attention to the rate at which marble gives way in such a moist climate as ours, and cited the effects of subaërial waste as these can be measured on the monuments of our graveyards and cemeteries. ${ }^{2}$ I would urge upon towngeologists, and those in the country who have no opportunities of venturing far afield, that they may do good service by careful scrutiny of ancient buildings and monuments. In the churchyards they will find much to occupy and interest them, not, however, like

${ }^{1}$ The first Report of this Committee was submitted to the Southport meeting of the Association in 1903. But the question is one of such importance in view of the rapidity with which some parts of our coast are in course of demolition that it deserves to be taken up as a national investigation. The country at large should contribute to the expense of applying the best means for arresting the waste of its shores. At present the contest has to be carried on by the riparian proprietors, who are often quite unable adequately to cope with it. October, 1904.

2 Proc. Roy. Soc. Edin., vol. x. (1879-80) p. 518. 
Old Mortality, in repairing the tombstones, but in tracing the ravages of the weather upon them, and in obtaining definite measures of the rate of their decay.

The conditions under which subaërial disintegration is effected in arid climates, and the rate of its advance, are still less known, seeing that most of our information is derived from the chance observations of passing travellers. Yet this branch of the subject is not without importance in relation to the denudation not only of the existing terrestrial surface but of the lands of former periods, for there is evidence of more than one arid epoch in geological history. Here, again, a diligent examination of ancient buildings and monuments might afford some, at least, of the required data. In such a country as Egypt, for instance, it might eventually be possible to determine from a large series of observations what has been the average rate of surface-disintegration of the various kinds of stone employed in human constructions that have been freely exposed to the air for several thousand years.

Closely linked with the question of denudation is that of the Deposition of the material worn away from the surface of the land. The total amount of sediment laid down must equal the amount of material abstracted, save in so far as the soluble portions of that material are retained in solution in the sea. But we have still much to learn as to the conditions, and especially as to the rate, of sedimentation. Nor does there appear to be much hope of any considerable increase to our knowledge until the subject is taken up in earnest as one demanding and justifying a prolonged series of well-planned and carefully executed 
observations. We have yet to discover the different rates of deposit, under the varying conditions in which it is carried on in lakes, estuaries, and the sea. What, for instance, would be a fair average for the rate at which the lakes of each country of Europe are now being silted up? If this rate were ascertained, and if the amount of material already deposited in these basins were determined, we should be in possession of data for estimating not only the probable time when the lakes will disappear, but also the approximate date at which they came into existence.

But it is not merely in regard to epigene changes that further more extended and concerted observation is needed. Even among Subterranean movements there are some which might be watched and recorded with far more care and continuity than have ever been attempted. The researches of Professor George Darwin and others have shown how constant are the tremors, minute but measureable, to which the crust of the earth is subject. ${ }^{1}$ Do any of these phenomena indicate displacement of the crust, and, if so, what in the lapse of a century is their cumulative effect on the surface of the land?

More momentous in their consequences are the disturbances which traverse mountain-chains and find their most violent expression in shocks of Earthquake. The effects of such shocks have been studied and recorded in many parts of the world, but their causes are only partially understood. Are the disturbances due to a continuation of the same operation which at first gave birth to the mountains? Should they be regarded as 
symptoms of growth or of collapse? Are they accompanied with even the slightest amount of elevation or depression? We cannot tell. But these questions are probably susceptible of some more or less definite answer. It might be possible, for instance, to determine with extreme precision the heights above a given datum of various fixed points along such a chain as the Alps, and by a series of minutely accurate measurements to detect any upward or downward deviation from these heights. It is quite conceivable that throughout the whole historical period some deviation of this kind has been going on, though so slowly, or by such slight increments at each period of renewal, as to escape ordinary observation. We might thus learn whether, after an Alpine earthquake, an appreciable difference of level is anywhere discoverable, whether the Alps as a great mountain-chain are still growing or are now subsiding, and we might be able to ascertain the rate of the movement. Although changes of this nature may have been too slight during human experience to be ordinarily appreciable, their very insignificance seems to me to supply a strong reason why they should be sought for and carefully measured. They would not tell us, indeed, whether a mountainchain was called into being in one gigantic convulsion, or was raised at wide intervals by successive uplifts, or was slowly elevated by one prolonged and continuous movement. But they might furnish us with suggestive information as to the rate at which upheaval or depression of the terrestrial crust is now going on.

The vexed questions of the origin of Raised Beaches and Sunk Forests might in like manner be elucidated 
by well-devised measurements. It is astonishing upon what loose and unreliable evidence the elevation or depression of coast-lines has often been asserted. On shores where proofs of a recent change of level are observable it would not be difficult to establish by accurate observation whether any such movements are taking place now, and, if they are, to determine their rate. The old attempts of this kind along the coasts of Scandinavia might be resumed with far more precision and on a much more extended scale. Methods of instrumental research have been vastly improved since the days of Celsius and Linnæus. Mere eye-observations would not supply sufficiently accurate results. When the datum-line has been determined with rigorous accuracy, the minutest changes of level, such as would be wholly inappreciable to the senses, might be detected and recorded. If such a system of watch were maintained along coasts where there is reason to believe that some change in the relative level of sea and land is taking place, it would be possible to follow the progress of the movement and to determine its rate.

But I must not dwell longer on examples of the advantages which geology would gain from a far more general and systematic adoption of methods of experiment and measurement in elucidation of the problems of the science. I have referred to a few of those which have a more special bearing on the question of geological time, but it is obvious that the same methods might be extended into almost every branch of geological dynamics. While we gladly and gratefully recognise the large amount of admirable work that 
has already been done by the adoption of these practical methods, from the time of Hall, the founder of experimental geology, down to our own day, we cannot but feel that our very appreciation of the gain which the science has thus derived increases the desire to see the practice still further multiplied and extended. I am confident that it is in this direction more than in any other that the next great advances of geology are to be anticipated.

While much may be done by individual students, it is less to their single efforts than to the combined investigations of many fellow-workers that I look most hopefully for the accumulation of data towards the determination of the present rate of geological changes. I would, therefore, commend this subject to the geologists of this and other countries as one in which individual, national, and international co-operation might well be enlisted. We already possess an institution which seems well adapted to undertake and control an enterprise of the kind suggested. The International Geological Congress, which brings together our associates from all parts of the globe, would confer a lasting benefit on the science if it could organise a system of combined observation in any single one of the departments of inquiry which I have indicated or in any other which might be selected. We need not at first be too ambitious. The simplest, easiest, and least costly series of observations might be chosen for a beginning. The work might be distributed among the different countries represented in the Congress. Each nation would be entirely free in its selection of subjects for investigation, and would 
have the stimulus of co-operation with other nations in its work. The Congress will hold its triennial gathering next year in Paris, and if such an organisation of research as I have suggested could then be inaugurated a great impetus would thereby be given to geological research, and France, again become the birthplace of another scientific movement, would acquire a fresh claim to the admiration and gratitude of geologists in every part of the globe. ${ }^{1}$

1 The hope here expressed has so far been realised by the appointment of a Committee of the Geological Congress at Paris in 1900 and the renewal and extension of this Committee at the following Meeting held in Vienna in 1903. The subjects of Earthquakes; Movements of elevation or depression in mountain chains and measurements of the value of Gravity were especially proposed for investigation. The recommendations of the Committee were approved by the International Association of Academies in London in the summer of 1904 and steps were then taken in the direction of international co-operation in each of the subjects suggested. Note added, October, 1904. 


\section{VII}

\section{The Life and Letters of Charles Darwin ${ }^{1}$}

$\mathrm{By}$ the universal consent of mankind, the name of Charles Darwin was placed, even during his lifetime, among those of the few great leaders who stand forth for all time as the creative spirits that have founded and legislated for the realm of Science. It is too soon to estimate with precision the full value and effect of his work. The din of controversy that rose around him has hardly yet died down, and the influence of the doctrines he propounded is extending into so many remote departments of human inquiry, that a generation or two may require to pass away before his true place in the history of thought can be definitely fixed. But the judgment of his contemporaries as to his proud pre-eminence is not likely ever to be called in question. $\mathrm{He}$ is enrolled among the Dii Majorum Gentium, and there he will remain to the end of the ages. When he was laid beside the illustrious dead in Westminster Abbey, there arose far and wide a lamentation as of personal bereavement. Thousands of mourners who knew only his writings, and judged of the gentleness and courtesy of his nature from these

${ }^{1}$ Contemporary Review, Dec., 1887. 
and from such hearsay reports as passed outwards from the privacy of his country home, grieved as for the loss of a dear friend. It is remarkable that probably no scientific man of his day was personally less familiar to the mass of his fellow-countrymen. He seemed to shun all the usual modes of contact with them. His weak health, domestic habits, and absorbing work kept him in the seclusion of his own quiet household. In later years his face was seldom to be seen at the meetings of scientific societies, or at those gatherings where the discoveries of science are expounded to more popular audiences. He shrank from public controversy, although no man was ever more vigorously attacked and more completely misrepresented. Nevertheless, when he died, the affectionate regret that followed him to the grave came not alone from his own personal friends, but from thousands of sympathetic mourners in all parts of the world, who had never known or seen him. Men had ample material for judging of his work, and in the end had given their judgment with general acclaim. Of the man himself, however, they could know but little, yet enough of his character shone forth in his work to indicate its tenderness and goodness. Men instinctively felt him to be in every way one of the great ones of the earth, whose removal from the living world leaves mankind poorer in moral worth as well as in intellect. So widespread has been this conviction, that the story of his life has been eagerly longed for. It might contain no eventful incidents, but it would reveal the man as he was, and show the method of his working and the secret of his greatness. 
At last, five years and a half after his death, the long expected Memoir has made its appearance. The task of preparing it was undertaken by his son, $\mathrm{Mr}$. Francis Darwin, who, having for the last eight years of his father's life acted as his assistant, was specially qualified to put the world in possession of a true picture of the inner life of the great naturalist. Most biographies are too long, but, in the present case, the three goodly volumes will be found to contain not a page too much. The narrative is absorbingly interesting from first to last. The editor, with excellent judgment, allows Darwin himself, as far as possible, to tell his own story in a series of delightful letters, which bring us into the very presence of the earnest student and enthusiastic explorer of Nature.

Charles Darwin came of a family which from the beginning of the sixteenth century had been settled on the northern borders of Lincolnshire. Several of his ancestors had been men of literary taste and scientific culture, the most noted of them being his grandfather, Erasmus Darwin, the poet and philosopher. His father was a medical man in large practice at Shrewsbury, and his mother, a daughter of Josiah Wedgewood of Etruria. Some interesting reminiscences are given of the father, who must have been a man of uncommon strength of character. He left a large fortune, and thus provided for the career which his son was destined to fulfil. Of his own early life and later years, Darwin has left a slight but most interesting sketch in an autobiographical fragment, written late in life for his children, and without any idea of its ever being published. From this outline we learn that he 
was born at Shrewsbury on the I2th of February, I809. Shortly before his mother's death, in 1817 , he was sent, when eight years old, to a day-school in his native town. But even in the period of childhood he had chosen the favourite occupation of his life; 'my taste for natural history,' he says, 'and more especially for collecting, was well developed. I tried to make out the names of plants, and collected all sorts of things-shells, seals, franks, coins and minerals. The passion for collecting which leads a man to be a systematic naturalist, a virtuoso, or a miser, was very strong in me, and was clearly innate, as none of my sisters or brother ever had this taste.' According to his own account, he was 'in many ways a naughty boy.' But there must have been so much fun and kind-heartedness in his transgressions, that neither parents nor teachers could have been very seriously offended by his pranks. What, for instance, could be said to a boy who would gravely pretend to a schoolfellow that he could produce variously tinted flowers by watering them with coloured fluids, or who gathered a quantity of fruit from his father's trees, hid it in the shrubbery, and then ran off to announce his discovery of a robbery; or who, after beating a puppy, felt such remorse that the memory of the act lay heavy on his conscience and remained with him to old age? In 1818 he was placed under Dr. Butler in Shrewsbury School, where he continued to stay for seven years until I 825 , when he was sixteen years old. He confesses that the classical training at that seminary was useless to him, and that the school as a means of education was, so far as he was 
concerned, simply a blank. Verse-making, and learning by heart so many lines of Latin or Greek, seem to have been the occupations of school that specially dwelt in his memory, the sole pleasure he could recall being the reading of some of Horace's Odes. $\mathrm{He}$ describes, however, the intense satisfaction with which he followed the clear geometrical proofs of Euclid, and the pleasure he took in sitting for hours in an old window of the school reading Shakespeare. $\mathrm{He}$ made acquaintance, too, with the poems of Thomson, Byron and Scott, but confesses that in later life, to his great regret, he lost all pleasure from poetry of any kind, even from Shakespeare.

The first book that excited in him a wish to travel was a copy of the Wonders of the World in the possession of a schoolfellow, which he read with some critical discrimination, for he used to dispute with other boys about the veracity of its statements. Nothing in the school-life could daunt his ardour in the pursuit of natural history. He continued to be a collector, and began to show himself an attentive observer of insects and birds. White's Selborne, which has started so many naturalists on their career, stimulated his zeal, and he became so fond of birds as to wonder in his mind why every gentleman did not become an ornithologist. Nor were his interests confined to the biological departments of Nature. With his brother, who had made a laboratory in the garden tool-house, he worked hard at chemistry, and learned for the first time the meaning of experimental research. These extra-scholastic pursuits, which he declares to have been the best part of his education at school, came somehow 
to be talked of by his companions, who consequently nicknamed him 'Gas'; and Dr. Butler, when he heard of them, rebuked the young philosopher, for 'wasting time on such useless subjects,' and called him a 'poco curante.' It was evident to his father that further attendance at Shrewsbury School would not advance young Darwin's education, and he was accordingly sent in 1825 , when he was a little over sixteen years old, to join his elder brother, who was attending the medical classes of the University of Edinburgh. It was intended that he should begin the study of medicine, and qualify himself for that profession; but he had already discovered that a sufficient competence would eventually come to him to enable him to live in some comfort and independence. So he went to the lectures with no very strong determination to get from them as much good as if he knew that his living was to depend on his success. He found them 'intolerably dull,' and records in maturer years his deliberate conviction that 'there are no advantages, and many disadvantages, in lectures compared with reading.' That he did not conquer his repugnance to the study of anatomy in particular is remarkable, when we consider how strong already was his love of biology, and how wholly it dominated his later life. Tenderness of nature seems to have had much to do with his repugnance. $\mathrm{He}$ could not bear the sight of suffering; the cases in the clinical wards in the Infirmary distressed him, and after bringing himself to attend for the first time the operating theatre, he rushed away before the operations were completed and never went back. But he afterwards came to 


\section{LIFE OF DARWIN}

regard as one of the greatest evils of his life that he had not been urged to conquer his disgust and make himself practically familiar with the details of human anatomy. It is curious, too, to learn with what aversion he regarded the instructions of the Professor of Natural History in the University. Jameson could certainly kindle, or at least stimulate, enthusiasm in some young souls, as the brilliant band of naturalists trained under him in Edward Forbes' time sufficiently proved. But to others he undoubtedly was, what Darwin describes him, 'incredibly dull.' If the professorial teaching was defective, however, the loss seems to have been in good measure made up by the companionship of fellow-students of kindred tastes, with whom the future naturalist explored the neighbourhood of Edinburgh. Collecting animals from the tidal pools of the estuary of the Forth, and accompanying the Newhaven fishermen in their dredging voyages for oysters, he found plenty of material for study, and employed himself in dissecting as well as he could. In the course of these observations he made his first recorded discovery, which was ' that the so-called ova of Flustra had the power of independent movement by means of cilia, and were, in fact, larvae.' As a part of his love of Nature and out-of-door employments, he became an ardent sportsman, rose even long before day, in order to reach the ground betimes, and went to bed with his shooting boots placed open close beside him, that not a moment might be lost in getting into them.

When two sessions had been passed at Edinburgh and no great zeal appeared for the medical profession, 


\section{PROPOSED CLERICAL CAREER 24I}

Darwin's father proposed to him that he should become a clergyman, for it was out of the question that the young student should be allowed to turn into an idle sporting man, as he bade fair to do. After some time given to reflection on this momentous change in his career, Darwin, who ' did not then in the least doubt the strict and literal truth of every word in the Bible,' agreed to the proposal. Many years afterwards, when he had risen to fame, and his photograph was the subject of public discussion at a German psychological society, he was declared by one of the speakers to have 'the bump of reverence developed enough for ten priests.' So that in one respect, as he says of himself, he was well fitted to be a clergyman. In another and more serious qualification, however, he found himself lamentably and almost incredibly deficient. If his two years at Edinburgh had not added much to his stock of professional knowledge, they seem to have driven out of his head what slender share of classical learning he had imbibed at Shrewsbury. He had actually forgotten some of the Greek letters, and had to begin again, therefore, at the very beginning. But after a few months of preliminary training he found himself able to proceed to Cambridge in the early part of the year 1828 , when he was now nearly nineteen years of age. So far as concerned academical studies, the three years at the University were, in his own opinion, as much wasted time as his residence at Edinburgh or his life at school had been. He attempted mathematics, which he found repugnant. In classics he did as little as he could; but in the end he took his B.A. degree, and got the 
tenth place on the list of those who did not go in for honours. The disgust for geology with which the Wernerian doctrines at Edinburgh had inspired him, prevented him from becoming a pupil of Sedgwick. It is curious to speculate on what might have been his ultimate bent had he then come under the spell of that eloquent, enthusiastic, and most lovable man. Not improbably he would have become an ardent geologist, dedicating more exclusively to that science the genius and industry which he devoted to biology and to natural history as a whole.

Some of the incidents of his Cambridge life which he records are full of interest in their bearing on his future career. Foremost among them stands the friendship which he formed with Professor Henslow, whose lectures on botany he attended. He joined in the class excursions, and found them delightful. But still more profitable to him were the long and almost daily walks which he enjoyed with his teacher during the latter half of his time at Cambridge. Henslow's wide range of acquirement, his modesty, unselfishness, courtesy, gentleness and piety, fascinated Darwin and exerted on him an influence which, more than anything else, tended to shape his whole future life. The love of travel, which had been kindled by his boyish reading, now took a deeper hold of him as he read Humboldt's Personal Narrative, and Herschel's Introduction to the Study of Natural Philosophy. He determined to visit Teneriffe, and even went so far as to inquire about ships. But his desire was soon to be gratified in a far other and more comprehensive voyage. At the close of his college life he was fortunate enough, 
through Henslow's good offices, to accompany Sedgwick in a geological excursion in North Wales. There can be little doubt that this short trip sufficed to efface the dislike of geology which he had conceived at Edinburgh, and to show him how much it was in his own power to increase the sum of geological knowledge. To use his own phrase, he began to 'work like a tiger' at geology.

But he now had reached the main turning-point of his career. On returning home from his ramble with Sedgwick he found a letter from Henslow, telling him that Captain Fitz-Roy, who was about to start on the memorable voyage of the Beagle, was willing to give up part of his own cabin to any competent young man who would, volunteer to go with him without pay as a naturalist. The post was offered to Darwin, and after some natural objections on the part of his father, who thought that such a wild scheme would be disreputable to his character as a future clergyman, was accepted. His intention of becoming a clergyman, and his father's wish that he should do so, were never formally given up; but from this time onward they dropped out of sight. The Beagle weighed anchor from Plymouth on the 27th of December, I831, and returned on the 2 nd of October, I 836 .

Of the voyage in the Beagle and its scientific fruits Darwin himself has left ample record in his Journal of Researches, and in the various memoirs on special branches of research which he afterwards published. The editor of the Biography has wisely refrained from repeating the story of this important part 
of his father's life. But he has given a new charm to it by printing a few of the letters written during the voyage, which help us to realise still more vividly the life and work of the naturalist in his circumnavigation of the world. We can picture him in his little cabin, working diligently at the structure of marine creatures, but driven every now and then to lie down as a relief from sea-sickness, which worried him during the voyage and which was thought by some to have permanently injured his health. We see him littering the deck with his specimens, and thereby raising the indignation of the prim first lieutenant, who declared he would like to turn the naturalist and his mess 'out of the place,' but who, in spite of this want of sympathy, was recognised by Darwin as a 'glorious fellow.' We watch him in the tropical forests and in the calm glories of the tropical nights with the young officers listening to his exposition of the wonders of Nature around them. And, above all, we mark his exuberant enthusiasm in the new aspects of the world that came before him, his gentleness, unfailing goodnature and courtesy, that endeared him alike to every officer and sailor in the ship. The officers playfully dubbed him their ' dear old philosopher,' and the men called him 'our flycatcher.'

For one who was to take a foremost place among the naturalists of all time-that is, in the true old sense of the word naturalist, men with sympathies and insight for every department of Nature, and not mere specialists working laboriously in their own limited field of research - there could hardly have been chosen a more instructive and stimulating journey than that which was 
provided for Darwin by the voyage of the Beagle. The route lay by the Cape de Verd Islands across the Atlantic to the coast of Brazil, southward to the Strait of Magellan, and up the western side of the South American continent as far as Callao. It then struck westward across the Pacific Ocean by the Galapagos archipelago, Taheiti, New Zealand, Sydney and Tasmania, turning round into the Indian Ocean by way of Keeling Islands and the Mauritius to the Cape of Good Hope, and then by St. Helena and Ascension Island to the coast of Brazil, where the chronometrical measurement of the world, which was the ostensible object of the Beagle's circumnavigation, was to be completed, and so once more across the Atlantic homewards. Almost every aspect of Nature was encountered in such a journey. The luxuriant forests of the tropics, the glaciers and snowfields of Tierra del Fuego, the arid wastes of Patagonia, the green and fertile Pampas, the volcanic and coral islets of midocean, the lofty Cordillera of a great continent, arose one by one before the eager gaze of the young observer. Each scene widened his experience of the outer aspects of the world, quickened his powers of observation, deepened his sympathy with Nature as a whole, and likewise supplied him with abundant materials for future study in the life-work which he had now definitely set before himself. We must think of him during those five momentous years as patiently accumulating the facts and shaping in his mind the problems which were to furnish the occupation of all his after life.

During the voyage he had written long letters to his 
friends descriptive of what he had seen and done. $\mathrm{He}$ likewise forwarded considerable collections of specimens gathered by him at various places. His scientific activity was therefore well known at home to his acquaintances, and even to a wider circle, for some of his letters to Henslow were privately printed and circulated among the members of the Cambridge Philosophical Society. It would have been difficult for any even of his most intimate friends to offer a plausible conjecture as to the line of inquiry in natural science that he would ultimately select as the one along which he more particularly desired to advance. An onlooker might have naturally believed that the ardent young observer would choose geology, and end by becoming one of the foremost leaders in that department of science. In his Journal of Researches, and in the letters from the Beagle now published, it is remarkable how much he shows the fascination that geology exercised upon him. He had thoroughly thrown off the incubus of Wernerianism. From Lyell's book and Sedgwick's personal influence he had discovered how absorbingly interesting is the history of the earth. Writing to his friend, W. D. Fox, from Lima, in the summer of 1835 , he expresses his pleasure in hearing that his correspondent had some intention of studying geology; which, he says, offers 'so much larger a field of thought than the other branches of natural history'; and, moreover, 'is a capital science to begin, as it requires nothing but a little reading, thinking and hammering.' While the whole of his Journal shows on every page how keen were his powers of observation, and how constantly he was on the 
watch for new facts in many fields of natural knowledge, it is to the geological problems that he returns most frequently and fully. And never before in the history of science had these problems been attacked by an actual observer over so vast a space of the earth's surface, with more acuteness and patience, or discussed with such breadth of view. There is something almost ludicrous in the contrast between his method of treatment of volcanic phenomena and that of his professor at Edinburgh only six short years before. But though geological questions, being the most obvious anci approachable, took up so large a share of his time and attention, he was already pondering on some of the great biological mysteries the unveiling of which in later years was to be his main occupation, and to form the basis on which his renown as an investigator was chiefly to rest.

On his return to England, in October I 836, Darwin at once took his place among the acknowledged men of science of his country. For a time his health continued to be such as to allow him to get through a large amount of work. The next two years, which in his own opinion were the most active of his life, were spent, partly at Cambridge and partly in London, in the preparation 'of his Journal of Researches, of the zoological and geological results of the voyage, and of various papers for the Geological and Zoological Societies. So keen was his geological zeal that, almost against his better judgment, he was prevailed upon to undertake the duties of honorary secretary of the Geological Society, an office which he continued to hold for three years. And at each period of enforced 


\section{LIFE OF DARWIN}

holiday, for his health had already begun to give way, he occupied himself with geological work in the field. In the Midlands he watched the operations of earthworms, and began those inquiries which formed the subject of his last research, and of the volume on Vegetable Mould which he published not long before his death. In the Highlands he studied the famous Parallel Roads of Glen Roy; and his work there, though in after years he acknowledged it to be 'a great failure,' he felt at the time to have been 'one of the most difficult and instructive tasks' he had ever undertaken.

In the beginning of I 839 Darwin married his cousin, daughter of Josiah Wedgwood, and grand-daughter of the founder of the Etruria Works, and took a house in London. But the entries of ill-health in his diary grow more frequent. For a time he and his wife went into society, and took their share of the scientific life and work of the metropolis. But he was compelled gradually to withdraw from this kind of existence which suited neither of them, and eventually they determined to live in the country. Accordingly, he purchased a house and grounds at Down in a sequestered part of Kent, some twenty miles from London, and moved thither in the autumn of 1842 . In that quiet home he passed the remaining forty years of his life. It was there that his children were born and grew up around him, that he carried on the researches and worked out the generalisations that have changed the whole realm of science, that he received his friends and the strangers who came from every country to see him; and it was there that, after a long and 


\section{HIS THEORY OF CORAL-ISLANDS}

laborious life, full of ardour and work to the last, he died at the age of seventy-three, on the Igth of April, I 882 .

The story of his life at Down is almost wholly coincident with the history of the development of his views on evolution, and the growth and appearance of the successive volumes which he gave to the world. For the first four years his geological tastes continued in the ascendant. During that interval there appeared three remarkable works, his volume on Coral Islands, that on Volcanic Islands, and his Geological Observations on South America. Of these treatises that on coral reefs excited the wonder and admiration of geologists for the simplicity and grandeur of its theoretical explanations. Before it was written, the prevalent view of the origin of these insular masses of coral was that which regarded each of them as built on the summit of a volcano, the circular shape of an atoll or ring of coral being held to mark the outline of the submerged crater on which it rested. But Darwin, in showing the untenableness of this explanation, pointed out how easily the rings of coral might have arisen from the upward growth of the reef-building corals round an island slowly sinking into the sea. $\mathrm{He}$ was thus led to look upon the vast regions of ocean dotted with coral islands as areas of gradual subsidence, and he could adduce every stage in the process of growth, from the shore-reef just beginning, as it were, to form round the island, to the completed atoll, where the last vestige of the encircled land had disappeared under the central lagoon. More recent researches by other observers have, in 
the opinion of some writers, proved that the widespread submergence demanded by Darwin's theory is not required to account for the present form and distribution of coral islands. But his work will ever remain a classic in the history of geology.

After working up the geological results of the long voyage in the Beagle, he set himself with great determination to more purely zoological details. While visiting the coast of Chili, he had found a curious new cirripede, to understand the structure of which he had to examine and dissect many of the common forms. The memoir, which was originally designed to describe only his new type, gradually expanded into an elaborate monograph on the Cirrepedes (barnacles) as a whole group. For eight years he continued this self-imposed task, getting at last so weary of it as to feel at times as if the labour had been in some sense wasted which he had spent over it, and this suspicion seems to have remained with him in maturer years. But when at last the two bulky volumes, of more than one thousand pages of text, with forty detailed plates, made their appearance, they were hailed as an admirable contribution to the knowledge of a comparatively little known department of the animal kingdom. In the interests of science, perhaps, their chief value is to be recognised not so much in their own high merit as in the practical training which their preparation gave the author in anatomical detail and classification. He spoke of it himself afterwards as a valuable discipline, and Professor Huxley truly affirms that the influence of this discipline was visible in everything which he afterwards wrote. 
It was after Darwin had got rid of his herculean labours over the 'Cirripede book' that he began to settle down seriously to the great work of his lifethe investigation of the origin of the species of plants and animals. One of the three volumes of the Biography is entirely devoted to tracing the growth of his views on this subject, and the preparation and reception of the great work on the Origin of Species. In no part of his task has the editor shown greater tact and skill than in this. From the earliest jottings, which show that the idea had taken hold of Darwin's mind, we are led onwards through successive journals, letters, and published works, marking as we go how steadily the idea was pursued, and how it shaped itself more and more definitely in his mind. It is impossible to condense this story within the limits of a Review article, and the condensation, even if possible, would spoil the story, which must be left as told in the author's own words. Briefly, it may be stated here that he seems to have been first led to ponder over the question of the transmutation of species by facts that had come under his notice during the South American part of the voyage in the Beagle-such as the discovery of the fossil remains of huge animals akin to, but yet very distinct from, the living armadillos of the same regions; the manner in which closely allied animals were found to replace one another, as he followed them over the continent; and the remarkable character of the flora and fauna of the Galapagos archipelago. 'It was evident,' he says, ' that such facts as these, as well as many others, could only be explained on the supposition that species gradually 
become modified; and the subject haunted me.' His first note-book for the accumulation of facts bearing on the question was opened in July 1837 , and from that date he continued to gather them 'on a wholesale scale, more especially with respect to domesticated productions, by printed inquiries, by conversation with skilful breeders and gardeners, and by extensive reading.' He soon perceived that selection was the secret of success in the artificial production of the useful varieties of plants and animals. But how this principle, so fertile in results when employed by man, could be applied in explanation of Nature's operations, remained a mystery to him until in October 1838 , when, happening to read for amusement Malthus' book On the Principle of Population, he found at last a theory with which to work. With this guiding principle he instituted a laborious investigation on the breeding of pigeons, and experiments on the flotation of eggs, the vitality of seeds, and other questions, the solution of which seemed desirable as his researches advanced. He says himself that, to avoid prejudice in favour of his own views, he refrained for some time from writing even the briefest sketch of the theory he had formed, and that it was not until June, I 842 , that he allowed himself the satisfaction of writing a very brief pencil abstract in thirty-five pages, which two years afterwards he enlarged to 230 pages, and had fairly copied out. This precious manuscript was the germ of the Origin of Species.

With characteristic caution, however, he kept his essay in his desk, and with equally characteristic ardour, industry and patience went on with the 
laborious task of accumulating evidence. His friends were of course well aware of the nature of his research, and of the remarkable views to which he had been led regarding the history of species. And as these views could hardly fail in the end to become generally known, it was desirable that the first publication of them should be made by himself. This having been urged upon him by Lyell, he began early in the year 1856 to write out his views in detail on a scale three or four times as large as that on which the Origin of Species afterwards appeared. This work he continued steadily for two years, when it was interrupted (June 1858) by the arrival of a remarkable manuscript essay by Mr. A. R. Wallace, who, working in the Malay archipelago, had arrived at conclusions identical with those of Darwin himself. Darwin's generoùs impulse was to send this essay for publication irrespective of any claim of his own to priority: but his friends, Lyell and Sir Joseph Hooker, persuaded him to allow extracts from his early sketch of 1844 , and part of a letter written to Professor Asa Gray in 1857 , to be read, together with $\mathrm{Mr}$. Wallace's contribution, before the Linnean Society, and to be printed in the Society's Journal. He now set to work upon that epitome of his observations and deductions which appeared in November 1859, as the immortal Origin of Species.

Those who are old enough to remember the publication of this work, cannot but marvel at the change which, since that day, not yet thirty years ago, has come alike upon the non-scientific and the scientific part of the community in their estimation of it. Professor Huxley has furnished to the Biography a 
graphic chapter on the reception of the book, and in his vigorous and witty style recalls the furious and fatuous objections that were urged against it. A much longer chapter will be required to describe the change which the advent of the Origin of Species has wrought in every department of science, and not of science only, but of philosophy. The principle of evolution, so early broached and so long discredited, has now at last been proclaimed and accepted as the guiding idea in the investigation of Nature.

One of the most marvellous aspects of Darwin's work was the way in which he seemed always to throw a new light upon every department of inquiry into which the course of his researches led him to look. The specialists who, in their own narrow domains, had been toiling for years, patiently gathering facts and timidly drawing inferences from them, were astonished to find that one who, to their eyes, was a kind of outsider, could point out to them the plain meaning of things which, though entirely familiar to them, they had never adequately understood. The central idea of the Origin of Species is an example of this in the biological sciences. The chapter on the imperfection of the geological record is another in the domain of geology.

After the publication of the Origin, Darwin gave to the world during a succession of years a series of volumes, in which some of his observations and conclusions were worked out in fuller detail. His books on the fertilisation of orchids, on the movements and habits of climbing plants, on the variation of animals and plants under domestication, on the effects of cross 
and self-fertilisation in the vegetable kingdom, on the different forms of flowers in plants of the same species, were mainly based on his own quiet work in the greenhouse and garden at Down. His volumes on the descent of man, and on the expression of the emotions in man and animals, completed his contributions to the biological argument. His last volume, published the year before his death, treated of the formation of vegetable mould, and the habits of earth-worms, and the preparation of it enabled him to renew some of the observations which had interested him in his younger days, and to revive some of the geological enthusiasm which so marked the earlier years of his life.

Such, in briefest outline, was the work accomplished by Charles Darwin. The admirable biography prepared by his son enables' us to follow its progress from the beginning to the close. But higher even than the intellect which achieved the work was the moral character which shone through it all. As far as it is possible for words to convey what Darwin was to those who did not personally know him, this has been done in the Life. His son has written a touching chapter, entitled, 'Reminiscences of my Father's Everyday Life,' in which the man as he lived and worked is vividly pictured. From that sketch, and from Darwin's own letters, the reader may conceive how noble was the character of the great naturalist. His industry and patience, in spite of the daily physical suffering that marked the last forty years of his life; his utter unselfishness and tender consideration for others; his lifelong modesty that led him to see the worst of his own work and the best of that of other men; his 
scrupulous honour and unbending veracity; his intense desire to be accurate even in the smallest particulars, and the trouble he took to secure such accuracy; his sympathy with the struggles of younger men, and his readiness to help them; his eagerness for the establishment of truth by whomsoever discovered; his interest up to the very last in the advancement of science; his playful humour; his unfailing courtesy and gratitude for even the smallest acts of kindness-these elements of a lofty moral nature stand out conspicuously in the Biography. No one can rise from the perusal of these volumes without the conviction that, by making known to the world at large what Darwin was as a man, as well as a great original investigator, they place him on a still loftier pinnacle of greatness than that to which the voice of his contemporaries had already raised him. 


\section{VIII}

\section{Hugh Miller : His Work and Influence ${ }^{1}$}

Among the picturesque figures that walked the streets of Edinburgh in the middle of last century, one that often caught the notice of the passer-by was that of a man of good height and broad shoulders, clad in a suit of rough tweed, with a shepherd's plaid across his chest and a stout stick in his hand. His shock of sandy-coloured hair escaped from under a soft felthat; his blue eyes, either fixed on the ground or gazing dreamily ahead, seemed to take no heed of their surroundings. His rugged features wore an expression of earnest gravity, softening sometimes into a smile and often suffused with a look of wistfül sadness, while the firmly compressed lips betokened strength and determination of character. The springy elastic step with which he moved swiftly along the crowded pavement was that of the mountaineer rather than of the native of a populous city. A stranger would pause to look after him and to wonder what manner of man this could be. If such a visitor ven-

${ }^{1}$ An Address given at the Centenary Celebration of his Birth held in Cromarty on 22nd August, 1902. 
tured to question one of the passing townsmen, he would be told promptly and with no little pride 'That is Hugh Miller.' No further description or explanation would be deemed necessary, for the name had not only grown to be a household word in Edinburgh and over the whole of Scotland, but had now become familiar wherever the English language was spoken, even to the furthest western wilds of Canada and the United States.

A hundred years have passed since this notable man was born, and nearly half that interval has elapsed since he was laid in the grave. The hand of time, that resistlessly winnows the wheat from the chaff of human achievement, has been quietly shaping what will remain as the permanent sum of his work and influence. The temporary and transitory events in his career have already, in large measure, receded into the background. The minor contests in which, from his official position, he was so often forced to engage are mostly forgotten; the greater battles that he fought and won are remembered rather for their broad and brilliant results than for the crowded incidents that gave them such vivid interest at the time. His contemporaries who still survive him-every year a sadly diminishing number-can look back across the half century and mark how the active and strenuous nature whose memory they so fondly cherish, now

' Orbs into the perfect star

We saw not when we moved therein.'

A juster estimate can doubtless be formed to-day of what we owe to him than was possible in his life-time. 
That the debt is great admits of no dispute, and that it is acknowledged to be due could hardly be more fittingly shown than by the wide-spread desire which has brought us here to-day from so many distant places in order to raise in the town of his birth, which he has made a place of pilgrimage to many a lover of English literature, a visible memorial of him in an institution of which he would himself have heartily approved.

In order adequately to realise the nature and extent of the work achieved by Hugh Miller during his too brief career, we should clearly picture to ourselves the peculiar conditions in which he grew up. Happily he has himself, in one of the most charming pieces of autobiography in the language, told the story of his youth and early manhood. Descended from both a Highland and a Lowland ancestry, he combined in his nature the vivid imagination and poetic impulse of the Celt with the more staid and logical temperament of the Teuton. He was born amidst an English-speaking community, but at a distance of only a few miles from the fringe of the mountainous region within which men use the Gaelic tongue. He knew some survivors of Culloden, and had heard his own grandfather tell how, when a stripling, he watched, from the hills above Cromarty, the smoke wreaths of the battle as they drifted along the ridge on the further side of the Moray Firth. From infancy he was personally familiar with the people of the hills and their traditions, as well as with the ways of the hardy fisher-folk and farmers of the plains. The hereditary predispositions of his mind were in this way fostered by contact with the two races from which they sprang. 
Happy in the possession of this racial blending, he was still more fortunate in the place of his birth. $\mathrm{He}$ used to remark with satisfaction that both Sir Roderick Murchison and he had been born on the Old Red Sandstone of the Black Isle; but while the career of the author of the Silurian System owed practically nothing to his birth-place, which he left while still an infant, Miller's life from beginning to end bore the impress of the surroundings amid which he was born and educated. It would hardly be possible to choose in this country a place of which the varied features are more admirably fitted to stimulate the observing faculties, to foster a love of nature, and to appeal to the poetic imagination than the winding shores, the scarped cliffs, the tangled woods, the wild boulderstrewn moors and distant sweep of blue mountains around Cromarty. And how often and lovingly are these scenes portrayed by him under every varying phase of weather and season! They had stamped themselves into his very soul and had become an integral part of his being.

\section{'The sounding cataract}

Haunted him like a passion; the tall rock, The mountain, and the deep and gloomy wood, Their colours and their forms were then to him An appetite, a feeling, and a love.'

But while Nature was his first and best teacher, he has told us in grateful words how much he owed to two uncles-hard-working, sagacious, and observant men, by whom his young eyes were trained to discriminate flower and tree, bird and insect, together with the teeming organisms of the shore, and whose 
high moral worth he, even as a boy, could appreciate. Having learnt to read while still of tender years, he developed an insatiable thirst for books. What he acquired in this way for himself seems to have been at least as useful as the training gained during the rather desultory years spent by him at the town grammar-school. He was an intelligent but wayward boy, as much ahead of his schoolmates in general information as in all madcap adventures among the crags and woods. When the time arrived at which he had to choose his calling in life, he selected an occupation that would still enable him to spend his days in the open air and gratify his overmastering propensity for natural history pursuits. Much to the chagrin of his family he determined to be a stonemason, and at the age of $\mathrm{I} 7$ was apprenticed to that trade. For some fifteen years he continued to work in quarries and in the erection of buildings in various districts of the north country, and even extended his experience for a short time into Midlothian. Deeply interesting and instructive is the record he has left of these years of mechanical toil. But amidst all the hardships and temptations of the life, the purity and strength of his character bore him nobly through. His keen love of nature and his intense enjoyment of books were a never-failing solace. $\mathrm{He}$ continued to gain access to, and even by degrees to possess, a considerable body of the best literature in our language, reading some of his favourite authors over twice in a year. He thus laid up a store of information and allusion which his retentive memory enabled him eventually to turn to excellent advantage. 
While still at school he had gained some notice for the verses which he wrote. In the intervals of his subsequent labours with mallet and chisel, he continued to amuse himself in giving metrical expression to his feelings and reflections, grave or gay. Conscious of his power, though hardly yet aware in what direction it could best be used, he resolved to collect and publish his verses. At the age of seven-andtwenty he accordingly gave to the world a little volume with the title Poems written in the leisure hours of a Fourneyman Mason. Not without some misgiving, however, did he make this first literary venture. Even before the voices of the 'chorus of indolent reviewers' could travel up from the south country, with their sententious judgments of the merits and defects of this new peasant-poet, he set himself to prepare some contributions in prose which might perchance afford a better measure of his quality. Some years before that time he had been out all night with the herring fleet, and he now sent to the Inverness Courier some letters descriptive of what he had then seen. These made so favourable an impression that they were soon afterwards reprinted separately. They marked the advent of a writer gifted with no ordinary powers of narration and with the command of a pure, nervous, and masculine style. The reception which these letters met with from men in whose judgment and taste he had confidence formed a turning point in his career. He now realised that his true strength lay not in the writing of verses, but in descriptive prose. Some years, however, still passed before he found the class of subjects 


\section{FIRST ESSAYS IN LITERATURE 263}

on which his pen could most effectively be exercised. In the meantime he began to record the legends and traditions of his native district. Most of these had been familiar to him from childhood, when he heard them from the lips of old grey-headed men and women, but they were dying out of remembrance as the older generations passed away. Part of his leisure for several years was given to this pleasant task, until there grew up under his hand a bulky volume of manuscript. This time he was in no hurry to publish; the book did not make its appearance until I 835, as his charming Scenes and Legends of the North of Scotland. In this work some of the most striking passages were to be found, not so much in the tales themselves which were narrated, as in the local colouring and graphic setting that were given to them. The writer displayed a singularly vivid power in the delineation of scenery, and his allusions to the geology of the district, then almost wholly unknown, attracted attention, since they showed that besides his keen eye for the picturesque above ground, he knew something of the marvels that lay beneath. He was feeling his way to what ultimately became his most cherished and most useful task. He had realised that his main object should be to know what was not generally known, 'to stand as an interpreter between nature and the public,' and to perform the service of narrating as pleasingly as he could, the facts which he culled in walks not previously trodden, and of describing, as graphically as might be, the inferences which he drew from them. 
Ever after his first day's experience as an apprenticed mason in a stone-quarry, of which he has left more than one impressive account, he was led to interest himself in the diversified characters of the rocks of the district. Even as a boy he had been familiar with the more obvious varieties of stone to be met with in a tract of country wherein the sedimentary formations of the Lowlands and the crystalline masses of the Highlands have been thrown side by side. But he had been attracted to them rather on account of their singular shapes or brilliant colours, than from any regard to what might have been their different modes of origin. Now, however, he had discovered that these rocks are really monuments, wherein are recorded portions of the past history of the earth, and he was full of hope that by patient study he might yet be able to decipher them. The supply of elementary treatises and text-books of science, in the present day so abundant, had hardly at that time begun to come into existence. Geology, indeed, had but recently attained a recognised position as a distinct branch of science. And even had the young stone-mason been able to possess himself of the whole of the scanty geological literature of the time, it included no book that would have solved for him the problems that daily confronted him as he pursued his labours in the quarry, or rambled in leisure hours along the shore. The best treatise which could have fallen into his hands and which would have been full of enlightenment and suggestion for him-Playfair's immortal Illustrations of the Huttonian Theory-had appeared seventeen years before; but we have no 


\section{FIRST GEOLOGICAL DISCOVERY 265}

evidence that it came in his way. He had laboriously to work out his problems for himself.

Innumerable as are the subjects for geological enquiry offered by the district of Cromarty, it was fortunate for Hugh Miller, and not less so for the cause of science, that chance placed him face to face in the most practical way with the Old Red Sandstone, and that he was, as it were, compelled to attempt to understand its history. While the lessons taught by the strata of the quarry had greatly impressed him, the abundant and well-preserved fossils among the Lias shales of the Eathie shore, which at spare moments he visited, had deepened that impression. It was while endeavouring to find these shales nearer home, on the western side of the Southern Sutor, that he stumbled upon the clays which contain the fish-bearing nodules of the Old Red Sandstone. This happy discovery, which was made in the autumn of I 830, the year after the publication of his Poems, marks an eventful epoch in his life, as well as an important date in the history of geological investigation.

At that time comparatively little was known of the Old Red Sandstone. Its very existence as a distinct geological system was disputed on the Continent, where no equivalent for it had been recognised. It was alleged to be a mere local and accidental accumulation, which could hardly be considered as of much historical importance, seeing that no representative of it had been found beyond the British Islands. Yet within the limits of these islands it was certainly known to bulk in no inconsiderable dimensions, covering many 
hundreds of square miles, and attaining a thickness of more than 10,000 feet. It had been clearly shown by William Smith, the Father of English Geology, to occupy a definite position beneath the Mountain Limestone, and above the ancient 'greywacke' which lay at the base of all the sedimentary series, and he had indicated its range over England and Wales on his map published as far back as I 8 I 5. In Scotland, too, its existence and importance as a mere mass of rock in the general framework of the country had long been recognised. Ami Boué had published in 1820 an excellent account of its igneous rocks, but without any allusion to the organic wonders for which it was yet to become famous. The extraordinary abundance of its fossil fishes, where it spreads over Caithness, had been made known to the world by Murchison in 1826, and in more detail the following year when Sedgwick and he read their conjoint paper on the conglomerates and other formations of the north of Scotland. But it may be doubted if any of these publications had found their way to Cromarty when Miller was gathering his first harvest of ichthyolites in the little bay within half-a-mile of the town. $\mathrm{He}$ had passed over that beach many hundreds of times in his boyhood without a suspicion of the treasures wrapped up in the grey concretions that lay tossing in the tideway. On breaking these stones, hoping to meet with a repetition of the Liassic organisms with which he had grown familiar at Eathie, he found a group of forms wholly different. At each interval of leisure he would repair to the spot, and, digging out the nodules from their matrix of clay, would 


\section{ENTERS RANKS OF SCIENCE 267}

patiently split them open and arrange them along the higher part of the beach, according to what seemed to be the natural affinities of the fossils enclosed within them. Scouring the parish for fresh exposures of the nodule-bearing clay, he was soon rewarded by the discovery of some six or eight additional deposits charged with the same remains. There was a strange fascination in this pursuit. $\mathrm{He}$ had, as it were, discovered a new world. No human eye had ever before beheld these strange types of creation. Though he was well acquainted with the marine life of the adjacent sea, he had never seen any creature that in the least resembled them, or served to throw light on their structure.

With no chart or landmark to guide him into this new domain of nature, he continued for years quietly to collect and compare. The first imperfect knowledge which he was able to acquire regarding the few modern representatives of the creatures disinterred by him at Cromarty was derived in 1836 from a perusal of the well-known memoir by Hibbert on the limestone of Burdiehouse. Next year, however, he made the acquaintance of Dr. Malcolmson, who eventually carried some of his specimens to London and the Continent, and was the means of bringing him into correspondence with Murchison and Agassiz. Hugh Miller was thus at last placed in direct communication with the world of science and into relation with the men who were most thoroughly versed in the subjects that had so long engrossed his thoughts, and most capable of helping him to clear away the difficulties that beset his progress. 
Meanwhile an important change had taken place in his condition of life. During the year 1834, after having worked for fifteen years in his calling of stonemason, he was offered the accountantship of the Commercial Bank agency to be opened at Cromarty. This offer, which came to him unasked and unexpected, was a gratifying mark of the esteem and confidence with which his character was regarded. He accepted it, not without some diffidence as to his competence for the duties required. It would, however, retain him in his native town, enable him to marry the accomplished girl to whom he had for years been attached, and afford him opportunity to prosecute the researches in the Old Red Sandstone of which he had now come to realise the importance. It likewise provided him with leisure to prepare contributions to different periodicals, which, though of no great consequence to his reputation, were of service in adding to an income narrow enough for the support of a wife and family. These writings had this further advantage, that they gave him a readier command of the pen, and accustomed him to deal with lighter as well as graver subjects of discussion, thus furnishing a useful training for what was ultimately to be the main business of his later life.

At this time ecclesiastical questions occupied public attention in Scotland to the exclusion of almost everything else. The Church was entering on that stormy period which culminated in the great Disruption of I843. Hugh Miller, who was at once an earnest Christian and a devoted son of the Church, watched the march of events with the deepest sympathy. As a 
thoroughly 'Establishment man' he had taken but slender interest in the previous Voluntary controversy, but the larger and more vital conflict now in progress filled him with concern. It was his firm conviction that the country contained ' no other institution half so valuable as the Church, or in which the people had so large a stake.' The anxiety with which the situation impressed him affected his sleep, and he would ask himself, 'Can I do nothing for my Church in her hour of peril ?' The answer which he found was to write his famous Letter from one of the Scotch people to Lord Brougham. This pamphlet was soon after followed by another entitled, The Whiggism of the Old School, as exemplified in the past history and present position of the Church of Scotland. These writings, so cogent in argument and so vigorous in style, had a wide circulation, and undoubtedly exercised much influence on the progress of the ecclesiastical controversy throughout the country. The leaders of the non-intrusion party, with whose cause he showed such keen and helpful sympathy, soon after the appearance of the first pamphlet invited Miller to confer with them in Edinburgh, and offered him the editorship of their projected newspaper, the Witness. With some misgiving as to his competence to meet all the various demands of a journal that was to appear twice a week, he accepted the proposal. Thus, after his five years' experience as a bank-accountant, he became at the beginning of 1840 , when he was thirty-seven years of age, the editor of an important newspaper, and he retained that position until his death.

Up to this time the name of Hugh Miller was but 
little known beyond his native district. His political pamphlets first gave it a wide reputation, and thenceforth his conduct of a journal that represented the interests of one of the great parties into which his country was divided kept him constantly before the eyes of the public. The Witness rapidly attained a large circulation. It appealed not merely to the churchmen whose views it advocated, but to a wide class of readers, who, apart from ecclesiastical polemics, could appreciate its high tone, its sturdy independence, its honesty and candour, and the unusual literary excellence of its leading articles. It not only upheld but raised the standard of journalism in Scotland. As a great moral force it exercised a healthy influence on the community. There cannot be any doubt that the powerful advocacy of the Witness was one of the main agencies in sustaining the energies of the nonintrusion party and in consolidating the position of the young Free Church. It is my own deep conviction that the debt which that Church owes to Hugh Miller has never yet been adequately acknowledged.

Before he had been many months in the editorial chair he began to publish in the columns of his paper the first of that brilliant succession of geological articles which attracted the attention of men of science, as well as of the general public, and which continued to be a characteristic feature of the Witness up to the end of his life. The first articles, describing his discoveries in the Old Red Sandstone of Cromarty, created not a little sensation among the geologists who had gathered in the year 1840 at the memorable 
meeting of the British Association in Glasgow. It was there that Agassiz, who had come fresh from the study of Swiss glaciers to the Scottish Highlands, announced that he had found clear evidence that the mountains of this country had once also nourished their glaciers and snow-fields. It was then, too, that the same illustrious naturalist gave the first account of the fossils found by Hugh Miller at Cromarty, one of which he named after its discoverer. In that gathering of eminent men, Murchison declared that the articles which had been appearing in the Witness were "written in a style so beautiful and poetical as to throw plain geologists like himself into the shade.' Buckland, famous for his own eloquent pages in the Bridgewater Treatise, expressed his unbounded astonishment and admiration, àffirming that 'he would give his left hand to possess such powers of description.' The articles were next year collected and expanded into his Old Red Sandstone, or New Walks in an Old Field - the first and, in some respects, the freshest and most delightful of all his scientific volumes.

In subsequent years there appeared in the same columns his Cruise of the Betsy-a series of papers written among the Western Isles, and full of the poetry and geological charm of that marvellous region; his Rambles of a Geologist, in which he included the results of his wanderings over Scotland between I 840 and I 848 , and other essays, the more important of which were collected with pious care by his widow, and published in a succession of volumes after his death. His First Impressions of England 
and its People appeared in 1846, and greatly increased the reputation of its writer as an observant traveller, an able critic, and an accomplished writer, possessing a wide and sympathetic acquaintance with English literature. The Footprints of the Creator, which followed in 1847 , was of a less popular character. Its detailed account of the structure of some of the fishes of the Old Red Sandstone is, however, of lasting value, though its controversy with the Vestiges of Creation has now little more than an historical interest. The Schools and Schoolmasters, after running as usual through the pages of the newspaper, was issued as a separate volume in 1852 , and was everywhere hailed as one of the most delightful and instructive of all his works. The Testimony of the Rocks, with the final proofs of which he was engaged on the last day of his life, was issued a few months after he had been laid to rest beside his friend Chalmers. Altogether of his collected writings, including those that appeared in his lifetime, a series of twelve volumes has been published, but many hundreds of articles of less permanent interest, yet each marked by the distinctive charm of its writer, remain buried in the files of the Witness.

If, from his writings alone, we judge of the extent and value of the work achieved by Hugh Miller, we can have little hesitation in believing that it is mainly his contributions to the literature of science that will hand his name down to future generations. Like so many other men who have attained distinction in the same field, he from the beginning to the end made geology his recreation, in the midst of other 
paramount pre-occupations. It furnished him with solace from the toils of the quarry and the building yard, it supplied him with a healthful relief from the labours of the bank, and when in later years he escaped each autumn for a few weeks of much needed leisure from the cares and responsibilities of the Editor's desk, it led him to ramble at will all over his native country, and brought him into acquaintance with every type of its rocks and its landscapes.

Unquestionably the most original part of his scientific work, that wherein he added most to the sum of acquired knowledge, is to be found in his reconstruction of the extinct types of fishes which he discovered in the Old Red Sandstone. The merit of these labours can hardly be properly appreciated unless it be borne in mind that he came to the study of the subject with no preliminary biological training, save what he could pick up for himself from an examination of such denizens of the waters of the neighbouring firths as he could meet with. But after prolonged search he could find in these northern seas no living creatures, the structure of which afforded him any clue to that of the fossil fishes of Cromarty. Some men had concluded that the organisms were ancient turtles, others that they were crustaceans, or even aquatic beetles. He had the sagacity, however, to surmise that they were probably all fishes, and he enjoyed the satisfaction afterwards of learning that Agassiz pronounced even the most bizarre amongst them to belong to that great division of the animal kingdom. He was guided by his own intuitive conception of what must have been the plan on which 
these long vanished types of organic structure had been fashioned. Huxley, who twenty years afterwards had occasion to subject the Old Red Sandstone fishes to critical study, and who brought to the inquiry all the resources of modern biology, has left on record the impression made on his mind by a minute revision of Hugh Miller's work. "The more I study the fishes of the "Old Red," he remarks, "the more am I struck with the patience and sagacity manifested in Hugh Miller's researches, and by the natural insight which in his case seems to have supplied the place of special anatomical knowledge.' He refers to the 'excellent restoration of Osteolepis,' in which even some of the minute peculiarities had not escaped notice, and he declares that Hugh Miller had made known almost the whole organisation of Dipterus, and had thus anticipated the most important part of Professor Pander's labours in the same field, the distinguished Russian palæontologist not having been aware that the work had already been done in Scotland.

But it is not, in my opinion, by the extent or value of his original contributions to geology that the importance of Hugh Miller's scientific labours and writings should be measured. Other men, who have left no conspicuous mark on their time, have surpassed him in these respects. What we more especially owe to him is the awakening of a wide-spread interest in the methods and results of scientific inquiry. More than any other author of his day, he taught men to recognise that beneath the technicalities and jargon of the schools, that are too apt to conceal the meaning 
of the facts and inferences which they express, there lie the most vital truths in regard to the world in which we live. He clothed the dry bones of science with living flesh and blood. $\mathrm{He}$ made the aspects of past ages to stand out picturesquely before us, as his vivid imagination conceived that they must once have been. He awakened an enthusiasm for geological questions, such as had never before existed, and this wave of popular appreciation which he set in motion has never since ceased to pulsate throughout the English-speaking peoples of the world. His genial ardour and irresistible eloquence swept away the last remnants of the barrier of orthodox prejudice against geology in this country. The present generation can hardly realise the former strength of that bigotry, or appreciate the merit of the service rendered in the breaking of it down. The well-known satirical criticism of the poet Cowper ${ }^{1}$ expressed a prevalent feeling among the orthodox of his day, and this feeling was still far from extinct when Miller began to write. I can recall manifestations of it even within my own experience. No one, however, could doubt his absolute orthodoxy, and when the cause of the science was so vigorously espoused by him, the voices of the objectors were finally silenced. There was another class of cavillers who looked on geology as a mere collecting of minerals, a kind of laborious trifling concealed under a cover of uncouth technical terms. Their view was well expressed by Wordsworth when he singled out for contemptuous scorn the enthusiast who carried a pocket hammer with which he chipped

1 See ante, p. 128. 
off splinters of the rocks, and left raw scars as marks of his progress. ${ }^{1}$

But a champion had now arisen who, as far as might be, discarding technicalities, made even the dullest reader feel that the geologist is the historian of the earth, that he deals with a series of chronicles as real and as decipherable as those that record human events, and that they can be made not only intelligible but attractive, as the subjects of simple and eloquent prose.

The absence of technical detail, which makes one of the charms of Hugh Miller's books to the nonscientific reader, may be regarded as a defect by the strict and formal geologist. Like every other branch of natural science, geology rests on a basis of observation, which frequently depends for its value upon the minuteness and accuracy of its details. To collect these details is often a laborious task, which is seldom undertaken save by those to whose department of the science they specially belong. A palæontologist cannot be expected to devote his time to the study of the microscopic characters of minerals and rocks. $\mathrm{He}$ leaves that research to the petrographer, who, on the other hand, will not readily embark on an investigation of the minute anatomy of fossil plants or animals. This specialisation, which has always to some extent existed, necessarily becomes more pronounced as science advances. The days are far past for Admirable Crichtons, and it is no longer possible for any one man to be equally versed in every branch of even a single department of natural knowledge.

1 The passage has been cited on p. 128. 
Hugh Miller's researches among the Old Red Sandstone fishes showed him to be above all a naturalist and palæontologist, capable of expending any needful amount of patient labour in working out the minutest details of organic structure. In other fields of geological inquiry, while he was far from undervaluing the importance of detail, he avoided the recapitulation of it in his writings. It interested him, indeed, only in so far as it enabled him to reach some broad conclusion or to fill in the canvas of some striking picture of bygone aspects of the earth's surface. Hence he did not apply himself to the minute investigation of problems of geological structure, and when he undertook any inquiry in that direction he was apt to start rather from the palæontological than the physical side. Thus the work of his last years along the shores of the Firth of Forth, wherein he sought to accumulate proofs of the comparatively recent upheaval of the land, was mainly based on the position of shells with reference to their present habitat in the adjacent seas. As a youth enthusiastically geological, I was privileged to enjoy his friendship, sometimes accompanying him on an excursion, and always spending an evening with him after one of his autumn journeys, that we might exchange the results of our several peregrinations. Only a few weeks before his death, on the last of those memorable evenings, he had his trophy of shells spread on the table, which enabled him to prove that at no very distant date Scotland was cut in two by a sea-strait that connected the Firths of Forth and Clyde. He had found marine shells at Bucklyvie, on the flat ground about midway between the two 
estuaries. Finding me not quite clear as to the precise geographical position of his shell-bed, he burst out triumphantly with the lines placed by Scott at the head of the chapter in Rob Roy, which tells of the journey of Bailie Nicol Jarvie and Osbaldistone into the Highlands:

'Baron of Bucklyvie

May the foul fiend drive ye,

And a' to pieces rive ye,

For building sic a toun,

Where there's neither horse meat, nor man's meat, nor a chair to sit doun.'

I remember, too, that on that occasion I had brought with me the detailed map of Arthur's Seat at Edinburgh, of which I had just completed the geological survey, and I explained to him in some detail what I had found to be the structure of the hill. Having grasped the main succession of the rocks, he with characteristic rapidity passed from the particulars which I had given him to the events of which they were the record, and turning to his daughter, who was sitting near, he exclaimed to her, 'There, Harriet, is material for such an essay as has been prescribed to you at school.' Then in a few graphic sentences he drew a picture of what seemed to him to have been the history of the old volcano.

While various causes no doubt contributed in this country to the remarkable and rapid increase in the general appreciation of the interest of geological investigation, I feel assured that one of the chief of them has been Hugh Miller's imaginative grasp of the subject, and his eloquent advocacy. The personal 
experience of a single individual can count for little in an estimate of this kind; but for what it may be worth, I gladly avail myself of this opportunity to state mine. It was Hugh Miller's Old Red Sandstone that first revealed to me the ancient history that might lie concealed in the hills around me, and the meanings that might be hidden in the commonest stones beneath my feet. I had been interested in such objects, as boys are apt to be who spend much of their time in the open country. But it was that book which set me on the path of intelligent inquiry. And this experience must doubtless have been shared by many thousands of his readers, who never saw his living face and who never became geologists.

I have alluded to the excellence of his literary style -a characteristic which unfortunately is only too rare among writers in science. There can be little doubt that this feature of his work will constitute one of its claims to perpetual recognition. His early and wide acquaintance with our literature enabled him to intersperse through his pages many an apposite quotation and felicitous allusion. He had set before himself as models the best prose writers of the previous century, and the influence of Goldsmith upon him is especially notable. He thus acquired the command of pure, idiomatic and forcible language, wherein to clothe the arguments which he wished to enforce, to describe the landscapes which had imprinted themselves like photographs on his memory, and to present restorations of ancient lands and seas which his poetic temperament and powerful imagination called up before his eyes. Moreover, he had a keen sense of 
humour, which would show itself from time to time, even in the midst of a scientific discussion. He could not bear dulness in others, and strove to avoid it himself. Where his subject might have been apt to grow wearisome, he contrived to lighten it with unexpected flashes of pleasantry or with some pertinent words from a favourite author. This felicitous style seemed so spontaneous, and yet it was in reality the result of the most scrupulous attention. Even in his newspaper articles on the multifarious topics of the passing day, he continued to maintain the same high standard of composition. He has left as his literary monument a series of works that may serve as models of English writing.

In estimating a man's influence on the world we look not only at his work but on his character, often the more important and valuable of the two. Judged from this side, Hugh Miller's claims to our regard and admiration are not less strong for what he was than for what he did. Pious and pureminded, full of generous sympathies, and alive to all that was noblest and best in human life, he was endowed with a manly independence of nature which kept his head erect in every changing phase of his career, and won for him the respect of all, gentle and simple, who came in contact with him. Though naturally robust, his occupation as a mason had left behind some seeds of disease. $\mathrm{He}$ was at different times attacked with inflammation of the lungs and other disorders of enfeebled health. His strong sense of duty, however, kept him at his post when prudence earnestly counselled rest. At last the strain became 
too great, and brought a noble and well-spent life to a sudden and tragic end.

It is to me a valued privilege to take part to-day in the centenary celebration of such a man. The years slip away, and I am probably the only geologist now alive who knew Hugh Miller well. He was my earliest scientific friend. Some boyish articles I had written in an Edinburgh newspaper on a geological excursion to the Isle of Arran had gained me his acquaintance, and ever thereafter I enjoyed his friendship and profited by his encouragement. To his helpful intervention I owed my introduction to Murchison, and thence my entry into the Geological Survey. His death was one of the great bereavements of my youth. It is therefore with heartfelt gratification that here, in his native town, so early familiar to me from his graphic descriptions, I find myself permitted on this public occasion gratefully to express my life-long indebtedness to him for his noble example, for the stimulus of his writings, and for the personal kindness which I received at his hands. 


\section{Science in Education ${ }^{1}$}

WHEN the history of Education during the nineteenth century comes to be written, one of its most striking features will be presented by the rise and growth of Science in the general educational arrangements of every civilised country. At the beginning of the century our schools and colleges were still following, with comparatively little change, the methods and subjects of tuition that had been in use from the time of the Middle Ages. But the extraordinary development of the physical and natural sciences, which has done so much to alter the ordinary conditions of life, has powerfully affected also our system of public instruction. The medieval circle of studies has been widely recognised not to supply all the mental training needed in the ampler range of modern requirement. Science has, step by step, gained a footing in the strongholds of the older learning. Not without vehement struggle, however, has she

${ }^{1}$ An address to the students of Mason University College, Birmingham, at the opening of the session, on Tuesday, 4th October, 1898. 
been able to intrench herself there. Even now, although her ultimate victory is assured, the warfare is by no means at an end. The jealousy of the older régime and the strenuous, if sometimes blatant, belligerency of the reformers have not yet been pacified; and, from time to time, within our public schools and universities, there may still be heard the growls of opposition and the shouts of conflict. But these sounds are growing fainter. Even the most conservative don hardly ventures nowadays openly to denounce science and all her works. Grudgingly, it may be, but yet perforce, he has to admit the teaching of modern science to a place among the subjects which the university embraces, and in which it grants degrees. In our public schools a 'modern side' has been introduced, and even on the classical side an increasing share of the curriculum is devoted to oral and practical teaching in science. New colleges have been founded in the more important centres of population, for the purpose, more particularly, of enabling the community to obtain a thorough education in modern science.

The mainspring of this remarkable educational revolution has, doubtless, been the earnest conviction that the older learning was no longer adequate in the changed and changing conditions of our time; that vast new fields of knowledge, opened up by the increased study of nature, ought to be included in any scheme of instruction intended to fit men for the struggle of modern life, and that in this newer knowledge much might be found to minister to the highest ends of education. Nevertheless, it must be admitted that utilitarian considerations have not been wholly 


\section{SCIENCE IN EDUCATION}

absent from the minds of the reformers. Science has many and far-reaching practical applications. It has called into existence many new trades and professions, and has greatly modified many of those of older date. In a thousand varied ways it has come into the ordinary affairs of every-day life. Its cultivation has brought innumerable material benefits; its neglect would obviously entail many serious industrial disadvantages, and could not fail to leave us behind in the commercial progress of the nations of the globe.

So much have these considerations pressed upon the attention of the public in recent years that, besides all the other educational machinery to which I have referred, technical schools have been established in many towns for the purpose of teaching the theory as well as the practice of various arts and industries, and making artisans understand the nature of the processes with which their trades are concerned.

That this educational transformation, which has been advancing during the century, has resulted in great benefit to the community at large can hardly be denied. Besides the obvious material gains, there has been a widening of the whole range and methods of our teaching; the old subjects are better, because more scientifically taught, and the new subjects enlist the attention and sympathy of large classes of pupils whom the earlier studies only languidly interested. Nevertheless, it is incumbent on those who have advocated and carried out this change to ask themselves whether it has brought with it no drawbacks. They may be sure that no such extensive reform could possibly be introduced without defects appearing in it 


\section{ITS DEFECTS}

somewhere. And it is well to look these defects in the face, and, as far as may be possible, remove them. In considering how I might best discharge the duty with which I have been honoured of addressing the students of Mason College this evening, I have thought that it might not be inappropriate if, as a representative of science, I were to venture to point out some of the drawbacks as well as the advantages of the position which science has attained in our educational system.

At the outset no impartial onlooker can fail to notice that the natural reaction against the dominance of the older learning has tended to induce an undervaluing of the benefits which that learning afforded and can still bestow. In this College, indeed, and in other institutions more specially designed for instruction in science, provision has also been made for the teaching of Latin, Greek, and the more important modern languages and literatures. But in such institutions, these subjects usually hold only a subordinate place. It can hardly be denied that generally throughout the country, even although the literary side of education still maintains its preeminence in our public schools and universities, it is losing ground, and that every year it occupies less of the attention of students of science. The range of studies which the science examinations demand is always widening, while the academic period within which these studies must be crowded undergoes no extension. Those students, therefore, who, whether from necessity or choice, have taken their college education in science, naturally experience no little 
difficulty in finding time for the absolutely essential subjects required for their degrees. Well may they declare that it is hopeless for them to attempt to engage in anything more, and especially in anything that will not tell directly on their places in the final class-lists. With the best will in the world, and with even, sometimes, a bent for literary pursuits, they may believe themselves compelled to devote their whole time and energies to the multifarious exactions of their science curriculum.

Such a result of our latest reformation in education may be unavoidable, but it is surely matter for regret. A training in science and scientific methods, admirable as it is in so many ways, fails to supply those humanising influences which the older learning can so well impart. For the moral stimulus that comes from an association with all that is noblest and best in the literatures of the past, for the culture and taste that spring from prolonged contact with the highest models of literary expression, for the widening of our sympathies and the vivifying of our imagination by the study of history and philosophy, the teaching of science has no proper equivalents.

Men who have completed their formal education with little or no help from the older learning may be pardoned should they be apt to despise such help and to believe that they can very well dispense with it in the race of life. My first earnest advice to the science students of this College is, not to entertain this belief and to refuse to act on it. Be assured that, in your future career whatever it may be, you will find in literature a source of solace and refreshment, of 
strength and encouragement, such as no department of science can give you. There will come times, even to the most enthusiastic among you, when scientific work, in spite of its absorbing interest, grows to be a weariness. At such times as these you will appreciate the value of the literary culture you may have received at school or college. Cherish the literary tastes you have acquired, and devote yourself sedulously to the further cultivation of them during such intervals of leisure as you may be able to secure.

Over and above the pleasure which communion with the best books will bring with it, two reasons of a more utilitarian kind may be given to science students why they should seek this communion. Men who have been too exclusively trained in science, or are too much absorbed in its pursuit, are not always the most agreeable members of society. They are apt to be somewhat angular and professional, contributing little that is interesting to general conversation, save when they get a chance of introducing their own science and its doings. Perhaps the greatest bore I ever met was a man of science, whose mind and training were so wholly mathematical and physical that he seemed unable to look at the simplest subject save in its physical relations, about which he would discourse till he had long exhausted the patience of the auditor whom he detained. There is no more efficacious remedy for this tendency to what is popularly known as 'shop' than the breadth and culture of mind that spring from wide reading in ancient and modern literature.

The other reason for the advice I offer you is one of which you will hardly, perhaps, appreciate the 
full force in the present stage of your career. One result of the comparative neglect of the literary side of education by many men of science is conspicuously seen in their literary style. It is true that in our time we have had some eminent scientific workers, who have also been masters of nervous and eloquent English. But it is not less true that the literature of science is burdened with a vast mass of slipshod, ungrammatical and clumsy writing, wherein sometimes even the meaning of the authors is left in doubt. Let me press upon you the obvious duty of not increasing this unwieldy burden. Study the best masters of style, and when once you have made up your minds what you want to say, try to express it in the simplest, clearest, and most graceful language you can find.

Remember that, while education is the drawing out and cultivation of all the powers of the mind, no system has yet been devised that will by itself develop with equal success every one of these powers. The system under which we have been trained may have done as much for us as it can do. Each of us is thereafter left to supplement its deficiencies by self-culture. And in the ordinary science-instruction of the time one of the most obvious of these inevitable deficiencies is the undue limitation or neglect of the literary side of education.

But in the science-instruction itself there are dangers regarding which we cannot be too watchful. In this College and in all the other well-organised scientific institutions of the country, the principles of science are taught orally and experimentally. Every branch of knowledge is expounded in its bearings on other 
branches. Its theory is held up as the first great aim of instruction, and its practical applications are made subsequent and subordinate. Divisions of science are taught here which may have few practical applications, but which are necessary for a comprehensive survey of the whole circle of scientific truth. Now, you may possibly have heard, and in the midst of a busy industrial community you are not unlikely to hear, remarks made in criticism of this system or method of tuition. The importance of scientific training will be frankly acknowledged and even insisted upon, but you will sometimes hear this admission coupled with the proviso that the science must be of a practical kind; must, in short, be just such and no other, as will fit young men to turn it to practical use in the manufactures or industries' to which they may be summoned. The critics who make this limitation boast that they are practical men, and that in their opinion theory is useless or worse for the main purposes for which they would encourage and support a great scientific school.

Now I am quite sure that those science students who have passed even a single session in Mason College can see for themselves the utter fallacy of such statements and the injury that would be done to the practical usefulness of this institution, and to the general progress of the industrial applications of science, if such short-sighted views were ever carried into effect. There can be no thorough, adequate, and effective training in science unless it be based on a comprehensive study of facts and principles, altogether apart from any economic uses to which they may be 
put. Science must be pursued for her own sake, in the first instance, and without reference to any pecuniary benefits she may be able to confer. We never can tell when the most theoretical part of pure science may be capable of being turned to the most important practical uses. Who could have surmised, for instance, that in the early tentative experiments of Volta, Galvani, and others last century lay the germ of the modern world-grasping electric telegraph ? Or when Wedgwood, at the beginning of this century, copied paintings by the agency of light upon nitrate of silver, who could have foretold that he was laying the foundations of the marvellous art of photography.

There can be no more pernicious doctrine than that which would measure the commercial value of science by its immediate practical usefulness, and would restrict its place in education to those only of its sub-divisions which may be of service to the industries of the present time. Such a curtailed method of instruction is not education in the true sense of the term. It is only a kind of cramming for a specific purpose, and the knowledge which it imparts, being one-sided and imperfect, is of little value beyond its own limited range. I by no means wish to undervalue the importance of technical instruction. 'By all means let our artisans know as much as can be taught them regarding the nature and laws of the scientific processes in which they are engaged. But it is not by mere technical instruction that we shall maintain and extend the industrial and commercial greatness of the country. If we are not only to hold 
our own, but to widen the boundaries of applied science, to perfect our manufactures, and to bring new departments of Nature into the service of man, it is by broad, thorough, untrammelled scientific research that our success must be achieved.

When, therefore, you are asked to explain of what practical use are some of the branches of science in which you have been trained, do not lose patience with your questioner, nor answer him as you think such a Philistine deserves to be answered. Give him a few illustrations of the thousands of ways in which science, that might have been stigmatised by him as merely abstract and theoretical, has yet been made to minister to the practical needs of humanity. Above all, urge him to attend some of the classes of Mason College, where he will learn, in the most effectual manner, the intimate connection between theory and practice. If he chance to be wealthy, the experiment may possibly open his eyes to the more urgent needs of the institution and induce him to contribute liberally towards their satisfaction.

Among the advantages and privileges of your life at college there is one, the full significance and value of which you will better appreciate in later years. You have here an opportunity of acquiring a wide general view of the whole range of scientific thought and method. If you proceed to a science degree you are required to lay a broad foundation of acquaintance with the physical and biological sciences. You are thus brought into contact with the subjects of each great department of natural knowledge, and you learn enough regarding them to enable you to understand 
their scope and to sympathise with the workers who are engaged upon them. But when your academical career is ended, no such chance of wide general training is ever likely to be yours again. You will be dragged into the whirl of life, where you will probably find little time or opportunity to travel much beyond the sphere of employment to which you may have been called. Make the most, therefore, of the advantages which in this respect you meet with here. Try to ensure that your acquaintance with each branch of science embraced in your circle of studies shall be as full and accurate as lies in your power to make it. Even in departments outside the bounds of your own tastes and ultimate requirements, do not neglect the means provided for your gaining some knowledge of them. I urge this duty, not because its diligent discharge will obviously tell in your examinations, but because it will give you that scientific culture which while enabling you to appreciate and enjoy the successive advances of other sciences than that which you may select for special cultivation, will at the same time increase your general usefulness and aid you in your own researches.

The days of Admirable Crichtons are long since past. So rapid and general is the onward march of science that not only can no man keep pace with it in every direction, but it has become almost hopelessly impossible to remain abreast of the progress in each of the several sub-divisions of even a single science. We are entering more and more upon the age of specialists. It grows increasingly difficult for the specialists, even in kindred sciences, to remain in touch with each other. 


\section{TRAINING IN OBSERVATION}

When you find yourselves fairly launched into the vortex of life you will look back with infinite satisfaction to the time when you were enabled to lay a broad and solid platform of general acquirement within the walls of this College.

Perhaps the most remarkable defect in the older or literary methods of education was the neglect of the faculty of observation. For the training of the other mental faculties ample provision was made, but for this, one of the most important of the whole, no care was taken. If a boy was naturally observant, he was left to cultivate the use of his eyes as he best might; if he was not observant, nothing was done to improve him in this respect, unless it were, here and there, by the influence of such an intelligent teacher as is described in Mrs. Barbauld's famous story of Eyes and No Eyes. Even when science began to be introduced into our schools, it was still taught in the old or literary fashion. Lectures and lessons were given by masters who got up their information from books, but had no practical knowledge of the subjects they taught. Class-books were written by men equally destitute of a personal acquaintance with any department of science. The lessons were learnt by rote, and not infrequently afforded opportunities rather for frolic than for instruction. Happily this state of things, though not quite extinct, is rapidly passing away. Practical tuition is everywhere coming into use, while the old-fashioned cut-and-dry lesson-book is giving way to the laboratory, the field-excursion, and the school-museum.

It is mainly through the eyes that we gain our 
knowledge and appreciation of the world in which we live. But we are not all equally endowed with the gift of intelligent vision. On the contrary, in no respect, perhaps, do we differ more from each other than in our powers of observation. Obviously, a man who has a quick eye to note what passes around him must, in the ordinary affairs of life, stand at a considerable advantage over another man who moves unobservantly on his course. We cannot create an observing faculty any more than we can create a memory, but we may do much to develop both. This is a feature in education of much more practical and national importance than might be supposed. I suspect that it lies closer than might be imagined to the success of our commercial relations abroad. Our prevalent system of instruction has for generations past done nothing to cultivate the habit of observation, and has thus undoubtedly left us at a disadvantage in comparison with nations that have adopted methods of tuition wherein the observing faculty is regularly trained. With our world-wide commerce we have gone on supplying to foreign countries the same manufactured goods for which our fathers found markets in all quarters of the globe. Our traders, however, now find themselves in competition with traders from other nations who have been trained to better use of their powers of observation, and who, taking careful note of the gradually changing tastes and requirements of the races which they visit, have been quick to report these changes and to take means for meeting them. Thus, in our own centres of trade we find ourselves 
in danger of being displaced by rivals with sharper eyes and greater powers of adaptation.

It is the special function of science to cultivate this faculty of observation. Here in Mason College, from the very beginning of your scientific studies you have been taught to use your eyes, to watch the phenomena that appear and disappear around you, to note the sequence and relation of these phenomena, and thus, as it were, to enter beneath the surface into the very soul of things. You cannot, however, have failed to remark among your fellowstudents great inequalities in their powers of observation, and great differences in the development of these powers under the very same system of instruction. And you may have noticed that, speaking generally, those class-mates who have shown the best observing faculty have taken a foremost place among their fellows. It is not a question of mere brainpower. A man may possess a colossal intellect, while his faculty of observation may be of the feeblest kind. One of the greatest mathematicians of this century who, full of honours, recently passed away from us, had so little cognisance of his surroundings, that many ludicrous stories are told of his child-like mistakes as to place and time.

The continued development of the faculty of prompt and accurate observation is a task on which you cannot bestow too much attention. Your education here must already have taught you its value. In your future career the use you make of this faculty may determine your success or your failure. But not only have your studies in this College trained your 
observing powers, they have at the same time greatly widened the range of your mental vision by the variety of objects which you have been compelled to look at and examine. The same methods which have been so full of benefit to you here can be continued by you in after life. And be assured that in maintaining them in active use you will take the most effective means for securing success in the careers you may choose to follow.

But above and beyond the prospect of any material success there is a higher motive which will doubtless impel you. The education of your observing faculty has been carried on during your introduction to new realms of knowledge. The whole domain of Nature has been spread out before you. You have been taught to observe thousands of objects and processes of which, common though they may be, you had previously taken no note. Henceforth, wherever you may go, you cannot wander with ignorant or unobservant eyes. Land and sea and sky, bird and beast and flower, now awaken in you a new interest, for you have learned lessons from them that have profoundly impressed you, and you have discovered meanings in them of which you had never dreamed. You have been permitted to pass within the veil of nature, and to perceive some of the inner mechanism of this world.

Thus, your training in science has not only taught you to use your eyes, but to use them intelligently, and in such a way as to see much more in the world around you than is visible to the uninstructed man. This widened perception might be illustrated from 
any department of natural science. Let me take, by way of example, the relation of the student of science towards the features and charms of landscape. It may be said that no training is needed to comprehend these beauties; that the man in the street, the holiday-maker from town, is just as competent as the man of science to appreciate them, and get quite as much pleasure out of them. We need not stop to discuss the relative amounts of enjoyment which different orders of spectators may derive from scenery; but obviously the student of science has one great advantage in this matter. Not only can he enjoy to the full all the outward charms which appeal to the ordinary eye, but he sees in the features of the landscape new charms and interests which the ordinary untrained eye cannot see. Your accomplished Professor of Geology has taught you the significance of the outer lineaments of the land. While under his guidance you have traced with delight the varied features of the lovely landscapes of the Midlands, your eyes have been trained to mark their connection with each other, and their respective places in the ordered symmetry of the whole scene. You perceive why there is here a height and there a hollow; you note what has given the ridges and vales their dominant forms and directions; you detect the causes that have spread out a meadow in one place and raised up a hill in another.

Above and beyond all questions as to the connection and origin of its several parts, the landscape appeals vividly to your imagination. You know that it has not always worn the aspect which it presents to-day. You have observed in these ridges proofs that 
the sea once covered their site. You have seen the remains of long extinct shells, fishes, and reptiles that have been disinterred from the mud and silt left behind by the vanished waters. You have found evidence that not once only, but again and again, after vast lapses of time and many successive revolutions, the land has sunk beneath the ocean and has once more emerged. You have been shown traces of underground commotion, and you can point to places where, over central England, volcanoes were once active. You have learnt that the various elements of the landscape have thus been gradually put together during successive ages, and that the slow processes, whereby the characteristic forms of the ground have been carved out, are still in progress under your eye.

While, therefore, you are keenly alive to the present beauty of the scene, it speaks to you at every turn of the past. Each feature recalls some incident in the strange primeval history that has been transacted here. The succession of contrasts between what is now and what has been fills you with wonder and delight. You feel as if a new sense had been given to you, and that with its aid your appreciation of scenery has been enlarged and deepened to a marvellous degree.

And so too is it with your relation to all the other departments of Nature. The movements of the clouds, the fall of rain, the flow of brook and river, the changes of the seasons, the succession of calm and storm, do not pass before your eyes now as they once did. While they minister to the joy of life, they speak to you of that all-embracing system of process and law that governs the world. The 
wayside flower is no longer to your eyes merely a thing of beauty. You have found it to be that and far more-an exquisite organism in which the several parts are admirably designed to promote the growth of the plant and to perpetuate the life of the species, Every insect and bird is now to you an embodiment of the mystery of life. The forces of Nature, once so dark and so dreaded, are now seen by you to be intelligible, orderly and capable of adaptation to the purposes of man. In the physical and chemical laboratories you have been brought into personal contact with these forces, and have learnt to direct their operations, as you have watched the manifold effects of energy upon the infinite varieties of matter.

When you have completed your course of study and leave this College, crowned, I hope, with academic distinction, there will be your future career in life to choose and follow. A small number among you may, perhaps, be so circumstanced as to be able to devote yourselves entirely to original scientific research, selecting such branches of inquiry as may have specially interested you here, and giving up your whole time and energy to investigation. A much larger number will, no doubt, enter professions where a scientific training can be turned to practical account, and you may become engineers, chemists, or medical men. But in the struggle for existence, which every year grows keener amongst us, these professions are more and more crowded, so that a large proportion of your ranks may not succeed in finding places there, and may in the end be pushed into walks in life where there may be little or no opportunity for 
making much practical use of the knowledge in science which you have gained here. To those who may ultimately be thus situated it will always be of advantage to have had the mental training given in this Institution, and it will probably be your own fault if, even under unfavourable conditions, you do not find, from time to time, chances of turning your scientific acquirements to account. Your indebtedness to your professors demands that you shall make the effort, and, for the credit of the College, you are bound to do your best.

Among the mental habits which your education in science has helped to foster, there are a few which I would specially commend to your attention as worthy of your most sedulous care all through life.

In the first place I would put Accuracy. You have learnt in the laboratory how absolutely essential this condition is for scientific investigation. We are all supposed to make the ascertainment of the truth our chief aim, but we do not all take the same trouble to attain it. Accuracy involves labour, and every man is not gifted with an infinite capacity for taking pains. Inexactness of observation is sure sooner or later to be detected, and to be visited on the head of the man who commits it. If his observations are incorrect, the conclusions he has drawn from them may be vitiated. Thus all the toil he has endured in a research may be rendered of no avail, and the reputation he might have gained is not only lost but replaced by discredit. It is quite true that absolute accuracy is often unattainable; you can only approach it. But the greater the exertion you make 


\section{THOROUGHNESS AND BREADTH $30 \mathrm{I}$}

to reach it, the greater will be the success of your investigations. The effort after accuracy will be transferred from your scientific work to your everyday life and become a habit of mind, advantageous both to yourselves and to society at large.

In the next place, I would set Thoroughness, which is closely akin to accuracy. Again, your training here has shown you how needful it is in scientific research to adopt thorough and exhaustive methods of procedure. The conditions to be taken into account are so numerous and complex, the possible combinations so manifold, before a satisfactory conclusion can be reached. A laborious collection of facts must be made. Each supposed fact must be sifted out and weighed. The evidence must be gone over again and yet again, each link in its chain being scrupulously tested. The deduction to which the evidence may seem to point must be closely and impartially scrutinised, every other conceivable explanation of the facts being frankly and fully considered. Obviously the man whose education has inured him to the cultivation of a mental habit of this kind is admirably equipped for success in any walk in life which he may be called upon to enter. The accuracy and thoroughness which you have learnt to appreciate and practise at College must never be dropped in later years. Carry them with you as watchwords, and make them characteristic of all your undertakings.

In the third place, we may take Breadth. At the outset of your scientific education you were doubtless profoundly impressed by the multiplicity of detail which met your eye in every department of natural 
knowledge.' When you entered upon the study of one of these departments, you felt, perhaps, almost overpowered and bewildered by the vast mass of facts with which you had to make acquaintance. And yet as your training advanced, you gradually came to see that the infinite variety of phenomena could all be marshalled, according to definite laws, into groups and series. You were led to look beyond the details to the great principles that underlie them and bind them into a harmonious and organic whole. With the help of a guiding system of classification, you were able to see the connection between the separate facts, to arrange them according to their mutual relations, and thus to ascend to the great general laws under which the material world has been constructed. With all attainable thoroughness in the mastery of detail, you have been taught to combine a breadth of treatment which enables you to find and keep a leading clue even through the midst of what might seem a tangled web of confusion. There are some men who cannot see the wood for the trees, and who consequently can never attain great success in scientific investigation. Let it be your aim to master fully the details of the tree, and yet to maintain such a breadth of vision as will enable you to embrace the whole forest within your ken. I need not enlarge on the practical value of this mental habit in every-day life, nor point out the excellent manner in which a scientific education tends to develop it.

In the fourth place, I would inculcate the habit of wide Reading in scientific literature. Although the progress of science is now too rapid for any man to 
keep pace with the advance of all its departments, you should try to hold yourselves in touch with at least the main results arrived at in other branches than your own; while, in that branch itself, it should be your constant aim to watch every onward step that is taken by others, and not to fall behind the van. This task you will find to be no light one. Even were it confined to a survey of the march of science in your own country, it would be arduous enough to engage much of your time. But science belongs to no country, and continues its onward advance all over the globe. If you would keep yourselves informed regarding this progress in other countries, as you are bound to do if you would not willingly be left behind, you will need to follow the scientific literature of those countries. You must be able to read at least French and German. You will find in these languages a vast amount of scientific work relating to your own department, and to this accumulated pile of published material the journals of every month continue to add. In many ways it is a misfortune that the literature of science increases so fast; but we must take the evil with the good. Practice will eventually enable you to form a shrewd judgment as to which authors or papers you may skip without serious danger of losing any valuable fact or useful suggestion.

In the fifth place, let me plead for the virtue of Patience. In a scientific career we encounter two dangers, for the avoidance of which patience is our best support and guide. When life is young and enthusiasm is boundless; when from the details which 


\section{4

we may have laboriously gathered together we seem to catch sight of some new fact or principle, some addition of more or less importance to the sum of human knowledge, there may come upon us the eager desire to make our discovery known. We may long to be allowed to add our own little stone to the growing temple of science. We may think of the pride with which we should see our names enrolled among those of the illustrious builders by whom this temple has been slowly reared since the infancy of mankind. So we commit our observations to writing, and send them for publication. Eventually we obtain the deep gratification of appearing in print among well-known authors in science. Far be it from me to condemn this natural desire for publicity. But, as your experience grows, you will probably come to agree with me that if the desire were more frequently and energetically curbed, scientific literature would gain much thereby. There is amongst us far too much hurry in publication. We are so afraid lest our observations or deductions should be forestalled-so anxious not to lose our claim to priority, that we rush before the world, often with a halffinished performance, which must be corrected, supplemented, or cancelled by some later communication. It is this feverish haste which is largely answerable for the mass of jejune, ill-digested, and erroneous matter that cumbers the pages of modern scientific journals. Here it is that you specially need patience. Before you venture to publish anything, take the utmost pains to satisfy yourselves that it is true, that it is new, and that it is worth putting into print. 


\section{NECESSI'TY OF PATIENCE}

And be assured that this reticence, while it is a kindness to the literature of science, will most certainly bring with it its own reward to yourselves. It will increase your confidence, and make your ultimate contributions more exact in their facts as well as more accurate and convincing in their argument.

The other danger to which I referred as demanding patience is of an opposite kind. As we advance in our career, and the facts of our investigations accumulate around us, there will come times of depression when we seem lost in a labyrinth of detail out of which no path appears to be discoverable. We have, perhaps, groped our way through this maze, following now one clue, now another, that seemed to promise some outlet to the light. But the darkness has only closed around us the deeper, and we feel inclined to abandon the research as one in which success is, for us at least, unattainable. When this blankness of despair shall come upon you, take courage under it, by remembering that a patient study of any department of nature is never labour thrown away. Every accurate observation you have made, every new fact you have established, is a gain to science. You may not for a time see the meaning of these observations, nor the connection of these facts. But their meaning and connection are sure in the end to be made out. You have gone through the labour necessary for the ascertainment of truth, and if you patiently and watchfully bide your time, the discovery of the truth itself may reward your endurance and your toil.

It is by failures as well as by successes that the true ideal of the man of science is reached. The task 
allotted to him in life is one of the noblest that can be undertaken. It is his to penetrate into the secrets of Nature, to push back the circumference of darkness that surrounds us, to disclose ever more and more of the limitless beauty, harmonious order and imperious law that extend throughout the universe. And while he thus enlarges our knowledge, he shows us also how Nature may be made to minister in an everaugmenting multiplicity of ways to the service of humanity. It is to him and his conquests that the material progress of our race is mainly due. If he were content merely to look back over the realms which he has subdued, he might well indulge in jubilant feelings, for his peaceful victories have done more for the enlightenment and progress of mankind than were ever achieved by the triumphs of war. But his eye is turned rather to the future than to the past. In front of him rises the wall of darkness that shrouds from him the still unknown. What he has painfully accomplished seems to him but little in comparison with the infinite possibilities that lie beyond. And so he presses onward, not self-satisfied and exultant, but rather humbled and reverential, yet full of hope and courage for the work of further conquest that lies before him.

Such is the task in which you may be called to share. When you have entered upon it and have learnt something of its trials and responsibilities, as well as of its joys and rewards, you will look back with gratitude to the training you received within the walls of this College. You will feel even more keenly than you do now how much you owe to the patient 


\section{STUDENTS' OUTLOOK}

kindness and educational skill of your teachers and to the healthy stimulus of contact and competition with your class-fellows. Most heartily do I wish you success in your several careers. Following up the paths which have been opened for you here, may it be yours to enlarge still further the circle of light which science has gained, and to wrest from Nature new aids for the service of mankind. 


\section{$\mathrm{X}$}

\section{The Roman Campagna ${ }^{1}$}

Among the capitals of Europe Rome has long had the unique distinction of standing in the midst of a wide solitude. Other cities in their outward growth have incorporated village after village and hamlet after hamlet. As their streets and squares merge insensibly into a succession of villas and gardens, cottages and hedgerows, followed by the farms and fields of the open country, so the noise and stir of causeway and pavement gradually give way to the quieter sounds of rural life. But with the Eternal City this normal arrangement does not hold good. For sixteen centuries she has kept herself within her ancient walls which still surround her with their picturesque continuity of rampart and tower. Inside these barriers we still encounter, by day and by night, the 'fumum et opes, strepitumque Romæ.' But outside the gates we find ourselves on a lonely prairie that sweeps in endless grassy, almost treeless, undulations up to the base of the distant hills. The main roads, indeed, that radiate from the city, are bordered on either side, for the first mile or two, with a strip of suburban osterie,

${ }^{1}$ International Quarterly, June 1904: 


\section{FASCINATION OF THE CAMPAGNA 309}

booths and shops, varied here and there, perhaps, by a villa and its grounds. But these fringes of habitation are too narrow and short, and cling too closely to their respective arteries of traffic, seriously to affect the solitariness which broods over the intervening landscape up to the very foot of the walls.

This surrounding district, known as the Roman Campagna, possesses a singular fascination, which has been often and enthusiastically described. The endless and exquisite variety of form and colour presented by the plain and its boundary of distant mountains, together with the changing effects of weather and season on such a groundwork, would of themselves furnish ample subjects for admiration. But the influence of this natural beauty is vastly enhanced by the strange and solemn loneliness of a scene which living man seems to have almost utterly forsaken, leaving behind him only memories of a storied past which are awakened at every turn by roofless walls of longabandoned farm-buildings, mouldering ruins of medieva towers, fragments of imperial aqueducts, decayed substructures of ancient villas and the grass-grown sites of ancient cities whose names are forever linked with the early struggles of Rome. European travel offers few more instructive experiences than may be gained by wandering at will over that rolling sward, carpeted with spring-flowers, but silent save for the song of the larks overhead and the rustle of the breeze among the weeds below; when the mountainous wall of the Sabine chain from Soracte round to the Alban Hills gleams under the soft Italian sky with the iridescence of an opal, and when the imagination, attuned 


\section{IO THE ROMAN CAMPAGNA}

to the human associations of the landscape, recalls with eager interest, some of the incidents in the marvellous succession of historical events that have been transacted here. If, besides being keenly alive to all the ordinary sources of attraction, the visitor can look below the surface, he may gain a vast increase to his interest in the ground by finding there intelligible memorials of prehistoric scenes, and learning from them by what slow steps the platform was framed on which Rome rose and flourished and fell. He will thus discover that, as befitted the city which was to rule the world, its birthplace was fashioned by the co-operation of the grandest forces in Nature; that, on the one hand, subterranean upheaval and stupendous volcanic activity combined to build up the plain and hills of the Campagna, and that on the other, the universal and ceaseless working of the subaërial agencies has carved it into that varied topography which is typified in the isolation of the Seven Hills of Rome and of the many crags and ridges that served as sites for the towns of Latium and Etruria.

Seen from the crest of the Vatican ridge, the Roman Campagna stretches as a plain from the base of the steep front of the Apennines to the coast of the Mediterranean-a distance of some thirty English miles. To the north it is bounded by the ridge of Soracte and the nearer heights of Bracciano and Tolfa. To the south it runs up to the base of the Alban Hills and sweeps between them and the sea onwards till it merges into the flat and pestilential Maremma. Even from such a commanding point of view, however, this apparent plain can be seen to be far from 
having an even surface. Not only does it slope upward and inland from the coast, until, where it abuts against the foot of the hills, it has reached heights of 600 or 800 feet, but when looked at more closely it presents a somewhat diversified topography. Though the heights and hollows never vary much from the general average level, they include not only smooth, grassy ridges but also low cliffs that run along the declivities, rising sometimes into craggy scarps; likewise narrow gullies and ravines with steep walls, as well as wide, open, smooth-sided valleys. The surface is for the most part clothed with pasture; yet the brown and yellow rock that forms most of the plain protrudes in many places, not only where it has been laid bare by natural causes, but where it has been artificially cùt away or scooped into subterranean recesses.

Such a varied form of ground was eminently favourable for human settlement. The earliest races could find or make rock-shelters almost anywhere. The fertility of the soil afforded to their successors good pasturage and fields for tillage, while the hillocks, girt round with cliffs, and the flat-topped ridges, shelving precipitously to lower ground, offered excellent sites for fortification and defence. Owing to the porous nature of the ground, much of the rain sinks at once beneath the surface, instead of flowing off in brooks. Hence many of the valleys are usually dry, unless in wet seasons. But water can be obtained all over the district by sinking wells, and that this source of supply has been in use from a remote period and to an almost incredible extent, has been strikingly 
shown by the recent excavations beneath the pavements of the Roman Forum. It would be difficult to find anywhere a form of ground which shows better the influence of geological structure upon the early fortunes of a people.

With some portion of what has been written by Italian and other observers on this district, I have made myself acquainted, and having had the advantage of tracing on the ground the records of the successive stages through which the Campagna has come to be what it is, I propose in the following pages to give an outline of this prehistoric chronicle. I should like to attempt to present to the reader such a picture of the whole sequence of events as has vividly impressed itself on my own mind, avoiding, as far as may be practicable, technicalities and details. Three distinct successive phases can be recognised in this sequence. First came a time when the waves of the Mediterranean broke against the base of the steep front of the Apennines, and when all the low grounds around Rome, and for leagues to the north and south, lay sunk many fathoms deep. Next followed the chief period in the building up of the Campagna. A host of volcanoes rose along the sea-floor on the west side of Central Italy, when ashes, dust and stones were thrown out in such quantity and for so prolonged a time as to strew over the sea-bottom a mass of material several hundred feet thick. Partly from this accumulation and partly by an upheaval of the whole region of Italy, the sea-bottom with its volcanic cones was raised up as a strip of low land bordering the high grounds of the interior, and a few huge volcanoes were 


\section{AN OLD SEA-FLOOR}

subsequently piled up to a height of several thousand feet. Lastly succeeded the epoch in which the volcanic platform, no longer increased by fresh eruptions, was carved by subaërial agencies into the topography which it presents to-day. Each of these three phases has had its history legibly graven in the rocky framework of the Campagna, and some of its memorials may be recognised even within the walls of Rome.

I. The records of the first period lie beneath the Seven Hills on the left bank of the Tiber, but rise high above the plain on the right bank, where they form the chain of heights that culminates in Monte Mario, 455 feet above the level of the Mediterranean. These records, forming the series known to geologists by the name of Pliocene, consist of a lower bluishgrey clay and an upper group of yellow sands and gravels, the whole being probably a good deal more than 450 feet thick. The clay (Plaisancian) has been found to extend, with a remarkable persistence of aspect and contents, from the north to the south of Italy. It has yielded several hundred species of mollusks and other organisms, which show it to be a thoroughly marine silt, deposited on the bottom of a sea of some little depth.

At the time of the deposition of this clay the mountainous backbone of the country had already undergone the greater part of that prolonged series of terrestrial disturbances whereby solid sheets of limestone were folded, crushed, ruptured and driven together into a series of parallel ridges, having a general trend from northwest to southeast, and forming the nucleus of what is now the chain of the Apennines. 
At the epoch when our story begins, however, this chain was still incomplete, and probably a good deal lower, as well as narrower, than subsequent upheaval has made it. Instead of forming, as it now does, the lofty axis of a broad peninsula, it then consisted of a series of parallel islands and islets, separated from each other by long and often narrow sounds or channels. In general appearance it must have resembled parts of the coast of Dalmatia on the opposite side of the Adriatic. Many of the more prominent mountains of the region stood then entirely surrounded by the sea. The Sabine Hills, for example, rose as an island, while Soracte formed another island farther west. A long strait ran northwards by Rocca Sinibalda and Rieti to Terni; another of narrower width stretched towards Perugia and formed then the estuary of the Tiber. All the Roman Campagna, together with the low grounds on both sides of the Apennines, was at that time submerged under the sea. The great band of volcanic heights and cones that extends from Aquapendente to the Bay of Naples had not yet come into existence, but over their site the waters of the Mediterranean lay many fathoms deep.

The climate of Europe had for ages been of so genial a character that sub-tropical types of life had long flourished both in the sea and on the land of this quarter of the globe. But in the period of geological history with which we are now concerned, a remarkable diminution of temperature was in progress all over the Northern hemisphere. As the warmth grew less, the distribution of plants and animals came to be seriously affected. Many southern 


\section{CHANGES OF CLIMATE}

forms were extirpated from districts which they had long inhabited, while in their place came migrations of northern species. This modification made itself felt both on terrestrial and marine life. Thus in the Atlantic Ocean a number of northern shells, which had pushed their way southward even as far as the coasts of the Spanish peninsula, were able to enter the Mediterranean when a connection was opened between that inland sea and the main ocean outside. It is interesting to note that among the shells introduced into the Mediterranean basin at this time were Astarte borealis, Buccinum groenlandicum, Cyprina islandica, Panopaea norvegica and others whose appellations sufficiently indicate the latitudes where they now find their chief home. On the land, too, such quadrupeds as the reindeer and the now extinct mammoth wandered from the plains of Lapland and Russia to the shores of Italy. Eventually when the refrigeration gave way to the return of more genial conditions, the northern invaders died out. They have no living descendants now in the south of Europe.

The grey clay which forms the lower division of the Roman Pliocene series is best seen on the right side of the Tiber where it forms the lower half of the ridge of the Vatican and Monte Mario, and where for more than five-and-twenty centuries it has supplied material for making the bricks of which ancient and modern Rome has been so largely constructed. The same clay has been found at lower levels on the opposite side of the river. On the flanks of the Pincian Hill, at the Piazza di Spagna, it was exposed about twelve years ago in some excavations connected 


\section{I6 THE ROMAN CAMPAGNA}

with the adjustment of the aqueduct of the Aqua Vergine. Only a few feet below the crowded pavements of that busy thoroughfare lies the old seabottom with its abundant relics of marine life. In borings for water which have been made around Rome the same deposit has been ascertained to extend below the later volcanic formations of the Campagna. Thus at the Appia Antica fort, near the tomb of Cecilia Metella, the clay was entered at a depth of about 300 feet from the surface or eighty feet below the level of the sea. As the upper limit of the clay at Monte Mario lies about 200 feet above sea level and the distance from that outcrop to the fort in question is about six miles, it might be inferred that there is here evidence of a southeasterly dip of the deposit amounting to forty-six feet in a mile. But before any inference of this kind can be accepted, some considerations should be taken into account, of the highest interest and importance in relation to the early history both of the Campagna and of the Apennine chain.

Before dealing with these questions, however, let us complete the examination of the marine deposits of Monte Mario. In the valuable section disclosed on the slopes of that hill, the grey clay is seen to become sandy towards the top and to include seams of sand which rapidly increase in thickness, until, with their included layers of gravel, they form nearly the whole of the upper part of the ridge. These yellow sands, generally distinguished by the name of 'Astian,' have been traced, like the clay below them, along nearly the whole length of the Italian peninsula. The 
striking contrast which, in the nature of their material, they present to the clay, plainly points to a great alteration of the geography of the coasts at the time when they were deposited. The sea must have become rapidly shallower. Not improbably one of the uplifts now took place, whereby the land has been raised at intervals to its present height. The steepness of the descent of the mountains into the sea might not lead at once to much gain of land along the western coast; but instead of the grey mud that had previously accumulated in the deeper water, coarser sediment, brought down by numerous torrents from the hills, now spread out over the sea-bottom. Such a transition from the finest silt to gravel and sand could not fail to affect the distribution of the animals living along the coast-line. Âccordingly, on comparing the fossils in the sands with those of the clay, we see that while some of the shells, especially the larger and more massive kinds, continued to flourish in abundance; others, which found their most congenial haunts in tranquil waters, were driven further out to sea.

As the Pliocene deposits so well displayed at Rome are known to preserve throughout Italy the same twofold character, with the same types of sediment and of organic remains, the observer who tries to follow their development in the Campagna is soon puzzled by the way in which they there suddenly disappear and allow their place to be taken by later deposits of volcanic origin, which are known by the general designation of Tuff. The most astonishing example of this local peculiarity is to be found at 


\section{I 8 THE ROMAN CAMPAGNA}

the Monte Verde, south of the Janiculan ridge. The clays and sands which rise in horizontal layers almost to the top of Monte Mario are there entirely cut out, and the tuff, which lies as a mere thin capping on the crest of that hill, suddenly descends across the truncated edges of the Pliocene strata to the alluvial plain of the Tiber. On the opposite side of the river, the upper sands have been almost entirely removed and the tuff is found lying almost immediately on the lower clay. It is clear that there must have been an extensive, though no doubt local, erosion of these marine strata, before the main body of the tuff was laid down. By what agency this erosion was effected is not quite clear. Not improbably a gap occurs here in the record, representing an interval of considerable duration of which no chronicle has survived.

Passing over this hiatus, we still encounter marine deposits, but these are of volcanic origin, and leave us meanwhile to speculate in the dark as to whether the denudation was the work of the sea or of terrestrial waters. Owing to the thick covering of tuff which has overspread the Campagna and concealed all that lies below, it has become difficult to obtain adequate data for the discussion of this question, which is of considerable interest in the history of the Campagna. The most reliable evidence would be supplied by a series of borings across the district in different directions. Such a series may perhaps hereafter be undertaken for the purpose of obtaining water for the farms and homesteads, which sanguine patriots foresee taking in the future the place of the 
present solitude, and in that event, the geologists of Rome will no doubt be on the watch for all the information that can be gathered from this source as to the nature of the rocks underneath, and their relations to each other.

In the meantime, much might be done in this attractive department of local geology by a far more detailed study than has yet been attempted of the surroundings of the Campagna. In particular the recognisable stratigraphical horizons among the Pliocene strata should be definitely traced and mapped in detail, where they emerge from under the volcanic tuff. It would then be possible to measure the amount of erosion in various places, and to determine how far the spread of the volcanic sheet across older formations is due to actual unconformability and how far to simple overlap. At the same time, the precise height could be ascertained of the upper limit of the Pliocene deposits, and data would probably be obtained for determining not only the minimum amount of the uplift of the land since the Pliocene period, but also how far and in what directions there may have been any warping of the peninsula in the course of the elevation. We know from the observations of De Angelis that the Plaisancian clays, which at Monte Mario do not rise more than 200 feet above the surface of the Mediterranean, reach a height of as much as 1,050 metres $(3,445$ feet) in the upper part of the valley of the Arno, near Subiaco, only about thirty miles east from Rome, or an upheaval of as much as 108 feet in a mile. It remains still to discover how far this amount may 
fall short of the total extent of the post-Pliocene uplift of the Apennine chain.

Not improbably the deep and extensive erosion of the Pliocene formations before the deposition of the volcanic tuffs, and their elevation above sea-level were related phenomena, connected with the outbreak of the remarkable volcanic episode in the geological history of Central Italy, which has so profoundly modified the scenery of the country. In the yellow sands and gravels of Monte Mario no trace of volcanic detritus has been detected. Their sediments, containing pebbles of Rhaetic, Jurassic and Cretaceous rocks can hardly have come from any other source than the Apennine chain. But before their deposition had quite come to an end the Volcanic period was ushered in which forms the second stage of the history of the region.

II. We have now to deal with the records of one of the most interesting phases in the evolution of the framework of Italy-the period that witnessed the birth, development and extinction of a series of volcanoes which, starting on the sea-bottom in front of the western coast, gradually built up a tract of plains in some places thirty to forty miles broad and altogether perhaps as much as 200 miles long, finally crowned with majestic cones several thousand feet high. The chronicles of this episode being tolerably complete in the Roman Campagna, they enable us to follow the course of events with great clearness from the beginning to the end.

Nowhere in the district around Rome have the earliest indications of the oncoming of this volcanic 
period, the first mutterings, as it were, of the subterranean convulsions, been more instructively preserved than in the line of quarries that have been opened along the edge of the alluvial plain of the Tiber at the Torretta di Quinto, near the Ponte Molle, about two miles north from the city. The section of strata there exposed, which has long been known and often described, is at present undergoing rapid changes from the extensive excavations required to procure materials for the embankment of the river in its course through Rome. Nowhere, too, is the geologist more seductively wooed from the pursuit of his researches by the fascination of crowded historic associations. From the slopes above the quarries, he sees the Tiber catching the shadows of the Pons Milvius, where Maxentius met his doom. 'Below him rise the roofs of the Osterie, which on feast days repeat the noise and merriment that made the place notorious in the days of the Empire. Opposite him, a green hill marks the long-deserted site of Antemnæ, beneath which the Tiber winds as a silver band through its meadows far up past other old towns that have long since mouldered into dust. Looking across the green and purple expanse of the Campagna, dotted with its ruined towers, he sees the whole sweep of the blue rampart of the Sabine Hills-almost the only feature of the landscape that has remained the same. If from these memories of the past he turns to the long line of quarries, he is perchance rudely awakened to the strenuous present by gangs of workmen, digging, blasting, wheeling; by the rattle of laden wagons, and by an occasional explosion of gunpowder or 
dynamite. Passing through this busy scene, he soon perceives that the ancient bank against which the Tiber chafed when it was spreading out its high alluvial plain, has been quarried backward, and as the ground slopes upward from the plain, the cliff thus artificially cut open must be continually changing its face and becoming higher. At present there has been laid open an excellent section of strata forming part of the upper or sandy group of Monte Mario. These succeed each other in horizontal bands so diverse in form and colour as to give the cliff a markedly banded aspect.

At the southern end of this section some layers of coarse gravel may be seen cemented into a solid calcareous conglomerate full of large and well-preserved marine shells. A little further over comes a band of travertine-a compact variety of limestone which is one of the characteristic and economically important stones of the Campagna, for where of good quality, it makes an admirable firm cream-coloured buildingstone, which has been largely used from the early times of Roman history. To its durability the preservation of so many noble monuments of Republican and Imperial architecture is due. I may remark in passing that this material can now be seen in actual course of deposition from solution in the neighbourhood of Rome. The cold waters of the Anio have formed thick masses of it at the Tivoli Falls, and the warm springs of Bagni deposit it on the plain below. At the latter place its accumulation must have been going on for a vast period of time, seeing that it now covers a tract of the low ground to the north 
of the Anio, measuring about six miles from east to west and four miles from north to south. Here the quarries of ancient Rome were opened, and the modern city still draws its supplies from the same area. A smaller tract of similar stone has been worked for building material at Cisterna di Roma, about twenty-eight miles to the southeast of the city. A thin band of travertine, possibly a continuation of that at the Torretta di Quinto, forms a conspicuous cliff along the east side of the Via Flaminia, between Ponte Molle and the Porto del Popolo, and other detached masses of it make their appearance at various places further south.

These various outcrops of travertine, as I shall have occasion to show, have had an important influence in the excavation of the valley of the Tiber and the isolation of the hills of Rome. The material was probably deposited chiefly by hot springs containing abundant carbonate of lime in solution, and may be regarded as an accompaniment or sequel of volcanic activity. In most cases, thermal mineral springs depositing travertine make their appearance in the later phases of a volcanic period, and often continue long after every other manifestation of subterranean heat has died out. But at the Torretta di Quinto the sheet of travertine is found among the records of the beginning of the volcanic history. Another exceptional feature in this sheet is the proof that it was laid down on the floor of the sea, for it encloses the remains of some of the shells that lived at the time in that sea.

More direct and obvious proof of the breaking-out of volcanic eruptions is to be found in the strata that 


\section{THE ROMAN CAMPAGNA}

lie above the travertine. In some of these may be detected truly volcanic minerals such as felspar, augite and black mica, derived from the explosion of lava within eruptive vents and from the falling of the volcanic dust upon the silt and shells of the sea-bottom. Higher up more pronounced evidence of successive eruptions is furnished by abundant lapilli and scoriæ of black slaggy lava, and by bands of true tuff, composed almost or entirely of volcanic detritus.

This section at the Torretta di Quinto is of great interest as indicating that the volcanoes of the Campagna began their career under the sea. Similar evidence obtained at other places makes it probable that the whole chain of volcanoes in central and southern Italy, from those of Bolsena on the north to those of Naples and Sicily on the south, started their eruptions on the sea-floor. When the activity of this chain was at its height, a band of eruptive vents flanked the western coast from the neighbourhood of Aquapendente and Ovieto to perhaps as far as the Bay of Salerno. At first the cones formed round these vents were probably submerged, and were no doubt more or less washed down and levelled by the agitation of the sea, but as they were renewed by successive discharges, the larger examples among them may have risen above water and scattered their dust and stones into the air. These volcanic islets would then front the mainland of Italy, much as the Aeolian islands now flank the northern coast of Sicily. Etna, Lipari, Volcano, Stromboli and the other islets may be regarded as the last lineal descendants of the insular 
volcanoes to whose operations the scenery of Central and Southern Italy is so largely indebted.

The solid substances ejected by these volcanoes in the earlier stages of their history consisted mainly of fragmentary material - dust, sand, stones, scoriæ, and the other discrete forms in which molten lava is blown out of volcanic vents by the explosion of its absorbed vapours and gases. Sometimes pieces of limestone or other rock, which were torn away from the older formations underneath, are found dispersed through the volcanic detritus. This fragmentary material, now more or less compacted into the form of Tuff, extends throughout the length and breadth of the volcanic tract and must thus cover some thousands of square miles. In the Campagna, which lies upon it and derives thence its distinctive features, it reaches a thickness of 300 feet or more, while inland it overlaps the Pliocene deposits in detached outliers which run far up the Apennine valleys, reaching heights of I,200 feet and upward. Compared with the Pliocene strata that lie below it, the tuff presents some characteristic differences which at once arrest attention. It lacks the rapid alternation and variety of parallel layers so marked in the Astian sands. Yet it can generally be seen to possess a stratified arrangement. Here and there, indeed, this structure gives place to a tumultuous accumulation of coarse detritus, huddled together as it fell, large and small lumps of lava being confusedly mingled in the general matrix and forming the rock known to geologists as Agglomerate. Such coarser intercalations probably indicate proximity to centres of eruption, and in some cases may even mark the position of the vents them- 


\section{THE ROMAN CAMPAGNA}

selves. Alternations in the character of the successive beds of tuff may be regarded as evidence of variations in the energy and distribution of the active orifices. It may be added that the tuff supplied the Romans with various admirable building materials. In the days of the Kings and of the Republic, its more compact kinds were quarried in large quadrangular blocks for the construction of massive walls, while in later times some of its more incoherent varieties were discovered to be capable of forming the most durable concrete, which in the hands of Roman architects was employed with a boldness and skill that have never since been equalled.

That the materials of the tuff were assorted under water is suggested by their stratified structure. This inference is strengthened by the intercalation among them of sheets of sand, gravel, clay and marl. The layers of gravel are especially important, for their component pebbles of limestone and other non-volcanic stones are unmistakably fragments of Mesozoic rocks, which have been rolled along by running water from their original resting places among the Apennines so as to acquire smoothed and rounded forms. But though the tuff was accumulated under water, it presents a strong contrast to the clays and sands below it by its generally unfossiliferous character. Leaves, branches and stems of ilex, oak and other land-vegetation have been obtained from it at various places, sometimes as mere hollow moulds or in carbonised forms, but occasionally with the internal structure still preserved. Less frequently it has yielded the bones, antlers or tusks of terrestrial quadrupeds. But both the plants 


\section{TUFFS OF MARINE ORIGIN}

and animals have obviously been drifted from the land, and did not live where their remains have been found. It is worthy of remark that though so many observers have been at work in successive generations among the rocks of the Campagna, no undoubted example of marine mollusk has been recorded from the tuff in the interior of the Campagna. The crowds of shells in the Pliocene strata underneath are there absent. That the conditions required for the existence of an abundant marine fauna continued over this site until the beginning of the volcanic period is manifest from the crowded pteropods, lamellibranchs and gasteropods of the clays and sands. But as the eruptions increased in area and in intensity these conditions were eventually destroyed. The descent of continued showers of hot dust, ashes and stones over the sea-bottom, the rise of mephitic gases from below, as well as of hot springs that deposited sheets of travertine, must have made that sea-floor no congenial home for either plant or animal.

It has often been assumed that the tuff of the Roman Campagna was derived from the eruptions of the Alban volcano on the one side, and of the Bracciano volcano on the other. A careful study of the tuff, however, and a comparison of it with that of more ancient volcanic districts, the structure of which has been more fully laid open by prolonged denudation, leads, in my opinion, to a conviction that this assumption is founded on inaccurate observation. The rapidly varying and lenticular character of the materials when followed along the cliffs where they are exposed, and their occasional agglomeratic character which increases 
and diminishes in various directions, with no reference to the two great volcanic centres on each border of the district, point not to showers of detritus from these centres, or from any other vents at a distance, but to local eruptions from many and generally small vents, discharging here fine, there coarse materials, at different times and independent of each other. I have not myself been fortunate enough to detect a ' neck,' which would mark the site of one of these vents, nor so far as I am aware, has any example of this structure been recorded from the general body of the Campagna tuff. But this failure of proof, I am disposed to believe, is to be accounted for rather from the special kind of evidence required not having hitherto been recognised, or searched for with sufficient experience, than because it does not exist.

One of the tasks which I think might hopefully be undertaken in regard to the geological history of this district is that of seeking for proofs of the distribution of some of the vents whence the tuff was ejected. Among the numerous crags along the hillsides, and in the abundant stream-courses or fossi, where the naked rock has been laid bare all over the Campagna, sections might be met with that would help to solve this problem. The numerous unquestionable 'craters' of the Alban and Ciminian Hills belong to a much later stage of the volcanic period than that in which the main mass of tuff was formed. We must remember also, in considering this question, that the tuff, with its distinctive and persistent characters, stretches far beyond the limits within which the materials fell that were discharged from the Alban or 
Bracciano yolcanoes, even when these were at the height of their vigour. It can be followed in numerous detached tracts of valley-floor through the hills eastwards to Sora, and southwards to near Gaeta. There is reason to believe, indeed, that the type of small submarine vents extended all through the volcanic tract from its northern to its southern limit.

A little reflection will show that the sites of these vents may be expected to be difficult of detection. In the first place, though numerous, their small size may easily make them escape notice, even where they may have been wholly or partially laid bare by denudation. Probably a close parallel to their original forms and to the way in which they were in some places crowded together is to be found in the Phlegræan Fields near Naples-a district which well deserves the careful scrutiny of any one who desires to follow the volcanic history of the Roman Campagna. Its cones are terrestrial, indeed, not submarine. Being much younger, they have been far better preserved than those of the submarine stage of the period. One of them, Monte Nuovo, though now as cold and silent as the oldest of them, was thrown up so recently as A.D. I 538. Another, that of the Solfatara, is still a steaming vent, while Vesuvius from time to time vigorously asserts its claim to rank in the list of active volcanoes. These Neapolitan cones probably convey a fair idea of the general distribution and aspect of those of the Campagna, especially in the later time when the volcanic platform had eventually been raised above the level of the Mediterranean. We see, as in the case of the youngest and smallest of the 
three craters which have risen through each other to the north of Astroni, that some of the Neapolitan vents were only a few yards in diameter. And we learn also that at least one, and probably others of them, were the product of single eruptions, for Monte Nuovo, which is nearly 500 feet in height, was thrown up in the course of two days. Doubtless, these small and rapidly built monticules had many predecessors of like type on the Roman Campagna.

In the second place, the cones connected with the tuff of the district around Rome, being composed of loose fragmentary materials, would be easily washed down. No one can ramble over that area without being struck with the singular scarcity of solid lava among the endless exposures of tuff. It is true that around the great craters of the Alban and Ciminian Hills a good deal of lava can be seen to have been emitted. But these masses, like the volcanoes that gave vent to them, belong to that later stage of the volcanic history to which I have referred. Only to a trifling extent does the tuff of the Campagna appear to include contemporaneous sheets of lava. If, then, molten rock has hardly ever poured out at the surface, it may rarely have risen and consolidated in the upper parts of the throats of the volcanoes, so as to form there a hard core which would remain as a projecting knob when the surrounding loose ashes were levelled down by denudation.

In the third place, there can now be no doubt that the greater part of the sheet of tuff in the Roman Campagna was accumulated under the sea. This subject was for many years one on which various 
contradictory opinions were held. Some writers, from the general stratified structure, correctly maintained the marine origin of the tuff. Again, on the evidence of enclosed land-plants and animals, some observers have regarded it as a freshwater deposit, while others have looked upon it as a terrestrial formation. It is true, as I shall point out a little further on, that here and there, especially in its upper parts, the tuff includes intercalated bands of strata containing land and freshwater shells as well as bones of terrestrial mammals, and indicating that the floor of the sea had been converted into low land with brackish lagoons and lakes of fresh water. But as regards the main mass of the tuff of the Campagna, the question of its marine origin may now be considered as definitely settled by the researches of Professor Portis, of the University of Rome. In specimens of different varieties of the rock from all parts of the district, and previously supposed to be entirely unfossiliferous, this careful observer has found that foraminifera are often abundant and well preserved. These organisms are unequivocally marine, swimming freely in the upper waters and sinking when dead to mingle with the silt or to form of themselves an ooze on the bottom. We can thus understand how they might be borne along above a sea-floor on which molluscan life was hardly possible.

If, then, cones of loose ashes and scoriæ were thrown up on the bottom of the sea, they would obviously be apt to be rapidly lowered by the agitation of currents and ground swell, while those which rose above the surface of the water, as Lipari, Volcano 
and Stromboli do now, would be subject also to continual erosion by rain and to unceasing attack along their shores by wind-waves. They would thus tend to be ultimately planed down, their materials being strewn over the surrounding sea-bottom, so as to add to the general accumulating sheet of tuff. The rapidity with which this kind of demolition may be completed was impressively exemplified in this very area of the Mediterranean by the history of Graham Island, which in the summer of I83 I was thrown up by a submarine eruption off the southwest coast of Sicily. In the course of less than a month, a cone of loose cinders, scoriæ and pumice was piled up to a height, it is said, of more than 200 feet above sea-level, with a circumference of three miles and a large crater inside. In about three months, this volcano was levelled with the surface of the sea.

As a consequence of the prolonged eruptions, the sea along the west coast of Central Italy must have become increasingly shallow. This result may not improbably have been expedited by that uplift of the whole region to which reference has above been made. In course of time, not only would volcanic cones appear as islands above sea-level, but the action of winds, waves and tidal currents would throw up bars or lidi, like those of Venice or those of more ancient date which traverse the alluvial plain on either side of the mouth of the Tiber. Further deposition of sediment, either from the volcanoes or from the torrents of the Apennines, would lead to the silting up of the lagoons between these bars. The hollows on the newly gained land would eventually become 
fresh-water lakes, and the drainage from the mountains would find its way by numerous channels across the low plain into the sea. Thus, the Tiber, escaping from its narrow estuary among the hills not improbably continued its southwesterly course, so as to pass across what afterwards became the great volcanic district of Bolsena and to enter the sea somewhere between Civita Vecchia and Orbetello. The Anio would thus at that time be the main stream in the Roman Campagna.

From the layers of lacustrine or fluviatile deposits in the tuff and also from cavities and fissures in the limestone-hills, which then as now rose abruptly from the edge of the volcanic plain, an interesting series of organic remains has been obtained which throw a vivid light upon the plants and animals of the centre of Italy in the volcanic period. So far as yet discovered, the flora was on the whole similar to that which still survives in the district. But the fauna was strangely different. If the remains have been correctly identified, the land animals of the time consisted of a curiously mixed assemblage, including, on the one hand, many forms which have long been extinct, together with some which still inhabit the surrounding region; and on the other hand, quadrupeds characteristic of southern Europe or Africa, as well as a few whose descendants are only found much farther north. The open glades were traversed by various species of deer, gazelle and wild ox, most of which are no longer living but which comprised the red deer and the reindeer. There were likewise herds of more than one kind 


\section{4

of horse, whose bones have been found at some places in great numbers. The caverns and clefts in the hills were tenanted by lions and hyenas, lynxes and wild cats. The woods were haunted by brown bears, badgers, wolves and foxes. Strangest of all the denizens of the region were the huge pachyderms-mastodons, elephants, and rhinoceroses, including that northern form, the mammoth. Beavers built their dams across the smaller streams, while the hippopotamus disported himself in the rivers, which were likewise tenanted by several species of aquatic tortoises. There is occasionally something strangely incongruous in the circumstances under which the remains of these primeval creatures are found in places that have long been known only from their association with the course of Roman history. One of the most singular examples of this contrast was seen in the recent unearthing of a wellpreserved tusk of a hippopotamus a few inches underneath the pavement of the atrium of the Vestal Virgins in the Forum Romanum. There can be little doubt that the main part of this curiously varied fauna had established itself in Italy long before the volcanoes first began their eruptions and that many of its most singular and characteristic members continued to live on during the volcanic period, for their remains have been exhumed from some of the later deposits. A few like the otter, the mole, the hare and the fox have remained in this region down to the present day.

It was after the Campagna had become a landsurface, tenanted by this remarkable assemblage of 
animals, that the manifestations of volcanic energy reached their climax. Instead of finding outlets in many minor vents that discharged showers of ashes and stones, it now broke out in a few large orifices from which not only copious discharges of fragmentary materials, but also streams of lava were emitted. In the district around Rome this greater localisation and more violent activity were specially concentrated in two areas separated from each other by an intervening plain about thirty-five miles broad. On the south side of this plain, the group of the Alban Hills was built up by many successive eruptions; on the north side, a chain of important vents stretched from Bracciano northwards to the great crater of Bolsena. Of these two areas, the southern comes more closely into connection with Rome and the Campagna, and as it tells its story vividly and fully, it claims our more special attention.

The Alban Hills, so striking a feature in the scenery of the region and so indissolubly associated with the early chronicles of the Eternal City, consist essentially of one great volcanic cone of the type of Vesuvius, with a base about twelve miles in diameter. This cone has been so greatly truncated that its summit, from one side of the rim to the other, measures about six miles. The highest point of the rim is 3,07I feet above sealevel. Inside lies the huge cauldron-like depression that formed the original crater of the volcano, encircled with steep slopes and rocky walls save on the northwest side towards Rome, where the continuity of the crater-ring has been destroyed.

The abrupt truncation of this cone, the disappear- 


\section{6 'THE ROMAN CAMPAGNA}

ance of the western portion of its rim, the great size of its crater compared with the total height of the mountain, and the existence of a later cone and crater inside, together with a number of craters outside, suggest that the energy of the volcano culminated in a gigantic explosion, whereby the upper half of the cone, perhaps twice as high then as it is now, was blown away, leaving inside a yawning chasm or caldera that opened towards the west, where the wall was broken down. Such a paroxysm is known to have occurred in the history of other volanoes. In the case of Vesuvius, for example, Monte Somma remains as a fragment of the earlier and ampler condition of the mountain, before the catastrophe in which the upper part and the southern half of the cone were blown away. Since that event a new and smaller cone, forming the present Vesuvius, has been piled up on the southern segment of the old crater-rim.

The explosion that eviscerated the Alban volcano must have caused widespread desolation over the surrounding country. It was not improbably followed by a long interval of repose. But the subterranean energy was not exhausted, though it never again showed itself on so vigorous a scale. We can trace, indeed, the signs of its gradual enfeeblement. When it recommenced its activity the vent, which served as the channel by which its eruptions took place, still retained its central position. Round this vent a new but much smaller cone, bearing witness to less vigour of eruption, was built up in the middle of the crater. This younger mass rises in Monte Cavo to a height of 3 I 50 feet, the highest elevation on the whole 
mountain. It encloses a well-marked crater with the flat plain of the Campo di Annibale at its bottom. Eventually the central orifice came to be choked up by the lava that had risen and solidified with it, and as the volcanic forces still sought an outlet to the surface, they were compelled to find egress at other and weaker points of the volcano. At least two explosions took place on the old crater-rim and produced the deep-sunk and singularly impressive lakes of Albano and Nemi. Others broke out on the flanks of the great cone. Of these, the largest is marked by the crater of the Valle Arriccia, but at least two dozen of smaller size have been discriminated by the geologists of the Government Survey round the outer slopes of the volcano. These lateral vents not improbably mark the sites of the last eruptions.

While the Alban Mount was heaped up on the southern margin of the Campagna, another independent series of volcanoes rose on the northern border. The Lago di Bracciano marks the position of the vent that lay nearest to Rome. The huge cavity in which this sheet of water lies is some six miles in diameter and not improbably owes its origin to another and still more stupendous explosion than that of the Alban Hills. The level of the lake is 538 English feet above the surface of the Mediterranean, and as the water is as much as 900 feet deep, the bottom is 362 feet below sea-level. The crater wall still rises in the Rocca Romana to a height of 1,437 feet above the sea, or 900 feet higher than the lake which it encloses. Numerous streams of lava have poured down the outer slopes of the cone, especially on the southern 
flank. A few minor craters have been opened on its east side, and all round there still rise warm springs and emanations of sulphuretted hydrogen. To the north of this great vent lies another of similar character and origin but of smaller size, which now contains the Lago di Vico. The surface of this lake, which stands at a height of I, 663 feet above sea-level, is encircled by a crater-wall which on the west side mounts to nearly I,600 feet above the sheet of water which it encircles. To the northeast rises the volcanic mass of Monte Cimino, 3,464 feet high. Still farther north is the largest of all the Italian crater-lakes, the Lago di Bolsena, which is no less than twenty-eight miles in circumference.

Having regard to the great variety of material in these different volcanic piles and to the evidence furnished by them that they were formed by many successive eruptions, perhaps separated from each other by long intervals of time, we cannot but be impressed with the antiquity of the great subaërial cones and the protracted period required by each of them for its formation. We must remember, too, that from the very beginning of their history they were ceaselessly attacked by the various agents of subaërial erosion. The first showers of rain that fell on their young slopes of incoherent ashes gathered into runnels which would plough furrows in their descent to the plain. Century after century these watercourses were cut deeper and wider until they have attained the dimensions of the numerous fossi that now radiate from each crater-rim. In some cases these lines of erosion served as channels for the streams of lava that were 
poured down the slopes, as may be well seen on the southern flanks of the Bracciano volcano.

In most instances the molten rock stopped short on the flanks of its parent mountain, but it occasionally descended into the plain, as in the familiar example on the Via Appia, where the stream flowed from the side of the Alban volcano for some six miles to within a short distance of the site of the future capital of the world. The lava is here a firm, compact, durable stone admirably adapted for pavements, a use to which it has been extensively put for more than two thousand years, both within the walls and on the great high roads that radiate from them. Here, again, we see how bountifully Rome was favoured in regard to the materials needed for the construction of a great city.

The heaping of so much volcanic rock over the surface of the country must have greatly modified its topographical features. The drainage would especially be affected. Streams descending from the Apennines would find their direct passage to the sea blocked by the newly formed ridges, hills and mountains, and they might have to make long circuits before finding an exit. Lakes would gather in the hollows of the irregularly deposited tuff and others would fill up the cavities blown out by explosions, so as to become crater-lakes. The case of the Tiber may be cited in illustration of the deflection of drainage. In earlier times, as I have already remarked, this river probably flowed southwestwards across the site of the volcanic district of Bolsena and Viterbo; but in consequence of the subsequent eruptions, the lower 


\section{THE ROMAN CAMPAGNA}

part of its course was buried and the stream, diverted at a right angle, was made to run southeastwards, skirting the volcanic heights until, near Monte Soracte, it reached the plain between the base of the Bracciano and that of the Alban volcano, where it was able at length to find a seaward passage across the site of the future Rome.

That the early races of man witnessed and suffered from the latest eruptions may well be believed. The oldest traces of human occupation are stone implements, found more particularly in the higher rivergravels which, though they must undoubtedly date back to a remote antiquity, are certainly much later than the general mass of the tuff of the Campagna. Traditions of volcanic events seem to have survived into historic times. The pages of Livy, for example, contain references to showers of stones that fell in various places during the early centuries of Rome, and were regarded as portents of divine interposition in human affairs. We are told that in the hundredth year of the city showers of that kind fell on the Alban Mount, accompanied with loud noises from the wood on the summit. Again, in the year 540, fearful storms are said to have been experienced, while a fall of stones on the Alban Mount went on continuously for two days. Nineteen years later, amidst a miscellaneous series of prodigies, it is said to have rained stones at Aricia, Lanuvium, and on the Aventine. Such references have by some writers been interpreted as proofs of true volcanic eruptions, thus bringing the activity of the volcanoes around Rome well down into historic time. A supposed confirmation of this 
conclusion has been claimed to have been found on the ridge of Castel Gandolfo, where numerous burial urns containing cremated human remains have been unearthed five or six feet below the surface of the ground. Associated with some of these interments were fibulæ and objects in amber and bronze, together with specimens of Etruscan or Italo-Greek pottery of a beautifully Archaic pattern. It has been maintained that the superficial covering of volcanic material (which has even been called 'lava') has been the product of one or more volcanic eruptions, subsequent to the time of the burials, and hence that these eruptions must have taken place not only after the Stone Age, but even so late as after the coming of the Greek colonists. It has even been held that the shepherds of the Alban Hills, driven away from these heights by the violence of the volcanic disturbances, took refuge on the Seven Hills, where they founded the city and empire of Rome. More probably the volcanic detritus which overlies the cinery urns is of much more ancient date, the interments having been made by digging down through it, long after the last eruptions of the volcano had ceased.

It is not necessary, however, to refuse credence to all the portents recounted by Livy. More than two thousand years ago, when the events cited by him are alleged to have happened, the volcanic forces of the region must have been more potent than they now are, and various manifestations by them may have occurred which we do not expect to see repeated at the present day. Though the subterranean fires have been steadily dwindling, they even yet retain 


\section{$34^{2}$

heat enough to supply many thermal springs and to discharge large quantities of sulphuretted hydrogen gas. Now and then, also, they show a sudden though local manifestation of energy, and cause disturbances sufficiently alarming to fill the population with superstitious dread. An instance of this kind, which was witnessed within living memory, may here be cited as affording a reasonable explanation of some of the supposed supernatural prodigies recorded in Roman history. On the south side of Monte Soracte lies a dried-up lake which, no doubt on account of its offensive sulphurous exhalations, was called the Lagopuzzo, or Stinking Mere. The late Professor Ponzi has recorded that towards the end of the month of October, in the year 1831, a series of cracks suddenly opened on this old lake-bottom and a large piece of flat ground lying between them gradually sank out of sight. At the same time subterranean rumblings commenced and grew in intensity, mingled with detonations like the thundering of cannon. The surrounding population fled in terror to the neighbouring hills, whence looking back, they could see earth and water thrown up from the fissures, while a thick coating of dust fell over the whole district. The eruption began towards sunset and reached its culmination about seven o'clock in the evening. Next morning it was found that the Lagopuzzo was traversed by a chasm with vertical walls, at the bottom of which lay a sheet of water covered with a white scum and giving off a powerful odour of sulphuretted hydrogen. The ground around the cavity was strewn with pools of water and lumps of erupted earth, sometimes seventy 
cubic feet in size, which had been ejected to a distance of one hundred feet. The cannon-like detonations continued, but grew gradually less violent, each of them being accompanied by a copious discharge of the ill-smelling gas which threw the water into such commotion as to undermine the surrounding walls of alluvial earth and to cause portions of them to fall into the abyss. After a few days the disturbances ceased, leaving as their memorial a cross-shaped chasm upwards of three hundred feet in diameter, with walls rising some fifteen feet above the water, which was ascertained to be about one hundred feet deep.

Many such incidents as this may have been experienced in the history of ancient Rome. They would be quite enough to fill the minds of the populace with terror, and to call for a nine days' expiation and lustration of the city. The traditional legend of the chasm that opened in the Forum, and into which Curtius threw himself in full armour to propitiate the gods and save the city, may very well have been founded on a real event of this nature. The lake or quagmire in the Forum may have been another Lagopuzzo, rent open by an outburst of gas. The subterranean rumblings and bellowings (boati), which were accounted such dire portents in old times, were exactly repeated near Monte Soracte in the autumn of I83I.

Before we pass from this volcanic period to the consideration of the next phase in the history of the Campagna, it may be noted, as an interesting feature in the growth of the Italian peninsula, that the subterranean energy has been slowly dying out from north to south. The volcanoes of Central Italy have long 


\section{4

since entered into the closing or Solfatara stage, when only steam, hot vapours, and gases are emitted. But at the southern end of the chain lies the still vigorous Solfatara of Naples, with the various cones around it, some of which have been in eruption within the last few centuries, while Vesuvius continues to maintain a persistent though variable activity. Still farther south lie the Æolian Islands, where Volcano occasionally breaks out, while Stromboli remains, as it has done since the beginning of authentic history, in a state of constant ebullition and eructation. At the far extremity of the volcanic belt rises the colossal cone of Etna, which from time to time displays an energy worthy of its place among the great volcanoes of the globe.

III. We have traced how the platform of the Campagna has been step by step built up, partly by the accumulation of silt, sand, and gravel on the seafloor, partly by submarine volcanic ejections, and partly by a widespread uplift of the whole region above sealevel, and by continued subaërial volcanic activity. We now reach the third and last section of our history in which we have to consider how the present topography of the ground has been produced. A little reflection will convince us that, even before its elevation into land, the submerged surface of the district was probably far from presenting a dead flat, though it no doubt approached nearer to that form than it has ever done since. In spite of the levelling action of waves and currents, the sea-floor in front of the Apennine chain must have abounded in inequalities caused not only by the scour of the water, but more especially by the irregular distribution of the volcanic 
débris and the greater accumulation of the material around the submarine vents. Such inequalities would not only remain but grow more pronounced when the sea-bottom became a land-surface. Every subsequent outbreak of eruptive energy would aggravate them. But ultimately more potent still, because incessant in its operation, would be the influence of the various subaerrial agencies by which the land is continually abraded. It is to these agencies that we must mainly ascribe the present topography of the district. By a ceaseless process of sculpture, the volcanic platform has been ultimately carved into hillock and ridge, crag and cliff, valley and ravine. The tools which Nature has employed in this task have been the air, with its wide range of temperature and moisture, frost, rain and running water in all its manifold forms, from the tiniest rill to the broad current of the Tiber.

The key to the interpretation of the origin of the scenery of the Campagna is supplied to us by the lines of drainage. On the uplift of the region into land, the streams that descended from the steep front of the mountains would make their way seaward along the lowest levels which they could reach. The channels thus chosen by them would be maintained for the future, save where some landslip or volcanic eruption drove them to seek new courses for their waters. Failing such exceptional causes of diversion, the original lines of drainage would gradually be carved deeper into the framework of the land by the erosion of the water running in them. Thus the streams and the valleys which they have cut out for themselves 


\section{THE ROMAN CAMPAGNA}

are the most ancient features of the topography. Between them lie ridges and plateaux, which have gradually become prominent owing to the excavation of the intervening hollows. These eminences, though not subject to such marked and rapid demolition as the channels where running water is allowed free play, nevertheless undergo an appreciable decay. Attacked by the alternate expansion and contraction, due to the heat of clear Italian noons, quickly followed by the chill of starry Italian nights, the faces of the crags and cliffs are slowly disintegrated. Heavy rain washes off the loose crust and exposes a fresh surface to renewed attack. Alternate saturation by rain and drying in sunshine, the effects of frost and the abrading influence of wind, all contribute their share to the process of carving. By this universal process of denudation, while the topographical features have been made continually more pronounced, a considerable thickness of rock has no doubt been removed from the general surface of the whole ground since its elevation into land.

While it is thus easy to realise, as one traverses the Campagna, how its main topographical characteristics have been evolved, there is a special fascination in pursuing the investigation of particular features and trying to trace their origin in detail. Take, for instance, the story of the valleys. I can hardly imagine a more delightful task for a lover of geology than to work out the history of the Tiber-an investigation which, from the point of view we are here considering, still remains to be accomplished. Even from any of the hills of Rome it is not difficult to follow some 


\section{HISTORY OF 'THE 'TIBER}

of the stages of this history. We have seen that the river may have flowed at first south-westward, from its estuary among the Todi hills, across the site of the volcanic district to the sea somewhere north of Civita Vecchia. We have further found that the volcanic eruptions, which gave rise to the long line of heights between Aquapendente and Bracciano, probably blocked up the older channel, turned the stream towards the southeast, and for many miles kept it from once more bending seawards until at last it found its escape across the low ground of the Campagna. Looking from the Monti Parioli up the broad strath, we see the Tiber meandering through its flat alluvial plain which, from a width of a mile and a half, suddenly contracts immediately below us to less than a third of that space. The meaning of this constriction will be understood if we remember the position of the sheet of hard travertine to which allusion has already been made. When the river began to flow across this tract of country, the general level of the ground, not yet reduced by prolonged denudation, was no doubt a good deal above what it is now, and the bed of the stream may even have lain at a higher level than the tops of the present ridges on which Rome is built. After traversing the volcanic plain, the Tiber reached the western margin of this tract near where the Monti Parioli now rise. It then flowed southwards between the slopes of Monte Mario and the edge of the volcanic accumulations. It cut its way downward through the upper parts of the tuff, and at length encountered the sheet of travertine near the Ponte Molle. This hard stone 


\section{THE ROMAN CAMPAGNA}

would form for a time a barrier to the erosion which must have been comparatively rapid among the soft overlying tuffs. The river, ponded back into a lakelike expansion in front of the mouth of the Anio, was made to sweep in a wide curve into the softer Pliocene strata of the Vatican ridge on the right bank. The travertine extends through the Parioli ridge and round the base of the Pincian Hill. A similar rock emerges in the precipitous bank on the west side of the Aventine, and farther south at the Monte Della Creta, opposite the Magliana bridge. Even where this resisting stone disappears, its place has often been taken by a variety of tuff much more compact than the usual rock of the district. It is the presence of these more durable kinds of stone that has curbed the erosive progress of the river on its left bank, through the area on which the city stands. Where these barriers to its action were locally absent, the river was able to scoop out bays and recesses among the softer parts of the tuffs. The Capitoline, Palatine, Aventine and Celian hills have survived as more or less isolated eminences, owing to their fortunate possession of a more obdurate stone than the loose granular tuff of the surrounding Campagna. They once rose as islands out of the flood plain, and their steep sides, such as the Tarpeian rock and the cliffs that surrounded the original Roma Quadrata, owed their precipitousness mainly to the scour of the Tiber as it swept past their base.

Hardly less attractive would be the task of deciphering the history of the rough, craggy ridges and broad, smooth plateaux which form such distinctive features 
in the scenery of the Campagna. In this investigation we would mark how these differences of contour have mainly arisen from variations in the character of the volcanic tuff. Where the rock has possessed little coherence, and has consequently yielded more easily to the weather, it has crumbled away for the most part into gentle slopes which have been more or less shielded from further decay by a mantle of vegetation. But where the loose ashes and scoriæ have been accompanied with much fine dust, and have consolidated into a hard, compact stone, this material has survived to form the more rugged features of the scenery. Every stage in the progress of the sculpture may be instructively seen at the edge of the volcanic plain, where it winds round the projecting spurs and into the retreating hollows and bays of the great Apennine wall. Little imagination is needed to picture this plain as a sea-floor over which the waves rolled along the base of the mountains. But when this sea-floor was raised into land, the torrents from the uplands began to dig out of it winding channels, which were gradually deepened into gullies that unite into wider ravines as they descend. Between these defiles portions of the old plain have been left, along the sides of which the successive sheets of tuff run as bold ribs or as green slopes, according to their relative durability. Here and there one of these outliers, girdled round with vertical walls of rock, rises as an almost inaccessible platform above the ravines around, and has served as the site of some prehistoric citadel or of some medieval fortalice. All over the Campagna, indeed, from the very earliest 
ages, advantage has been taken of such defensible sites. They were selected as positions for the cities of Latium and Etruria, art often aiding to scarp their sides into steeper and more continuous crags than Nature had provided. They supplied convenient sites for the abundant suburbana or country villas and manors of ancient Rome, and they were used over again in the stormy Middle Ages for the erection of fortified farms and refuge towers.

A discussion of the history of the Campagna would probably be regarded as culpably incomplete without at least a reference to the causes that have led to the solitude and desolation of the region. There can be little doubt that in the days of the Empire the plain was thickly peopled and well cultivated. It could not have been the fever-stricken place which it has since become. The wealthy Romans were delighted to escape from the tumult of town to their quiet and healthy retreats in the country where, amid the pleasures and occupations of their farms, they could spend the hottest, and what is now the most insalubrious, season of the year. Yet there would seem to have been even then malarious tracts in the Campagna. Cicero boasts of the healthiness of Rome, compared with the pestilential character of the surrounding district. The porousness of the tuff all over the country, as I have above remarked, allows a large proportion of the rain to sink at once under ground, instead of flowing off into runnels and brooks. The water finds its way again to the surface at lower levels, either in the form of springs or oozing from the soil. In the hollows where the drainage accumulates, stagnant pools 
and marshes arise, which become the great nurseries of malaria. In the most flourishing days of Rome, when the whole surface of the Campagna was populous and in full cultivation, attention was alive to the importance of drainage. Probably many of the swampy tracts, whence mosquitoes now swarm, were then dry and turned over by the plough or spade. The general processes of agriculture prevented the accumulation of stagnant water and rotting vegetation. But with the fall of Rome and the devastation of the Campagna by successive hordes of barbarians, the villas fell into ruins, the inhabitants were in great measure extirpated, the farms remained untilled, the soil was left untouched, the water was allowed once more to gather and the vegetation to decay in the hollows. In the well-known words of Gibbon, "the Campagna of Rome was speedily reduced to the state of a dreary wilderness in which the land is barren, the waters are impure and the air is infectious.' Fever, which probably always found a home in various parts of the district, now stalked everywhere, until at the end of the twelfth century, when the population of the city had fallen to no more than 35,000 souls, Pope Innocent III. could declare that it was difficult to find there a man of forty years of age and hardly possible to meet with one of sixty.

No one will dispute that the sole, or at least the chief, cause of this long-continued depopulation is to be found in the prevalence of malarious fever. Nor, since modern science has so clearly revealed the nature and source of this decimating malady, can there be any hesitation as to the more important steps that must be 


\section{THE ROMAN CAMPAGNA}

taken to restore the region to healthfulness and fertility. Schemes are now in contemplation to reclaim these wastes to cultivation, and to repeople them with an industrious peasantry. While every lover of Italy will rejoice over the successful accomplishment of such a beneficent reform, those who have known the Campagna in the days of its desolation, and have found in its weird loneliness and quiet beauty, in its monuments and memories of the past, an inexpressible delight, will perhaps be pardoned if they regretfully look back upon another of the charms of Rome which shall then have passed away.

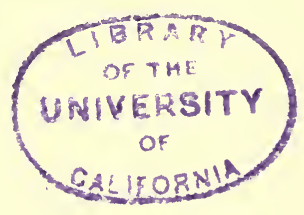





\section{DAY USE}

RETURN, TO DESK FROM WHICH BORROWED

EARTH SCIENCES I.MRARY

TEL: $642-29$ id below, or This book is due on the last date stamped.

on the date to which renewed.

Renewed books are subject to immediate recall.

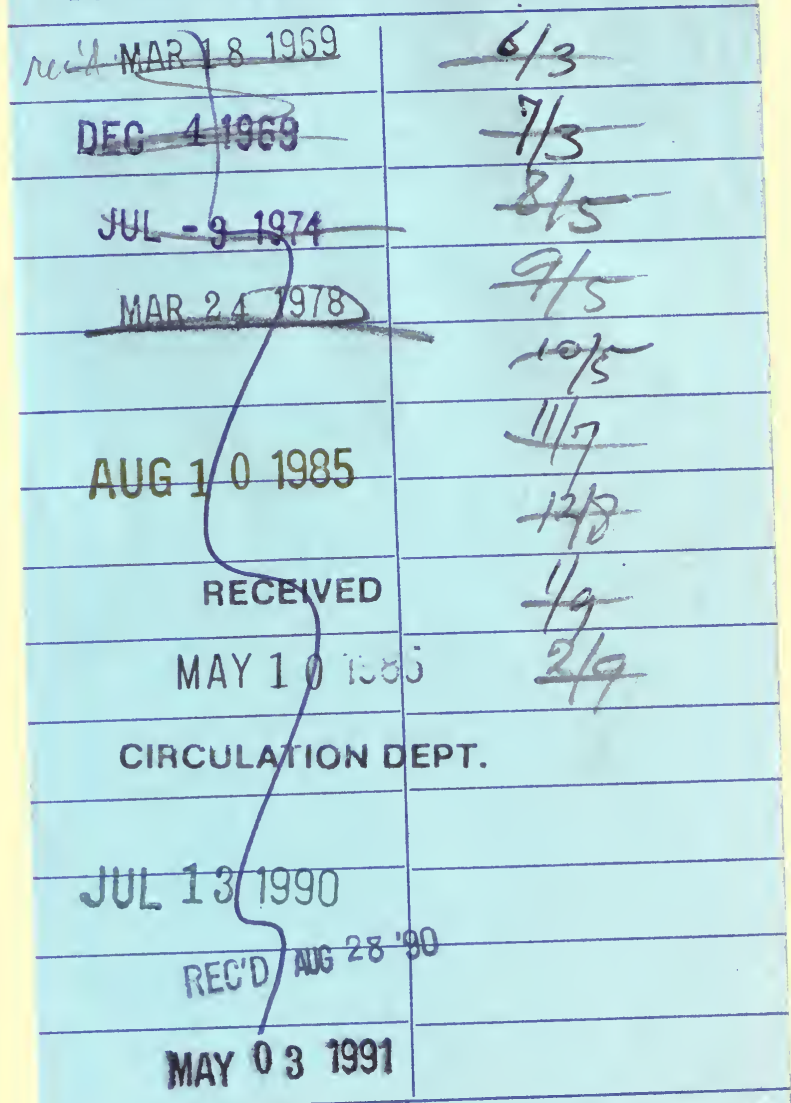

LD 21-40m-1,'68

General Library

(H7452s10) 476

University of California

Berkeley 
YC 21370

$-170$

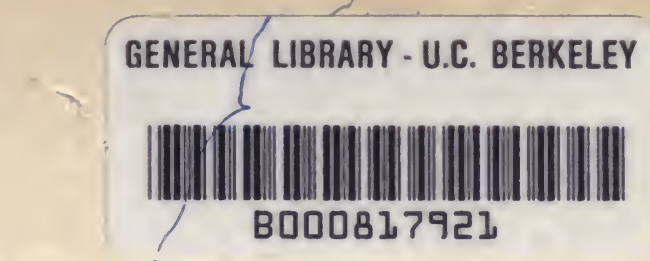


